ISSN 2411-2224

DOI: 10.17117/no.2014.01

https://ukonf.com/doc/no.2014.01.pdf

\title{
Наука, образование,
}

общество

\section{$2014 \cdot N 1(1)$}

\section{Science, education,}

\section{society}
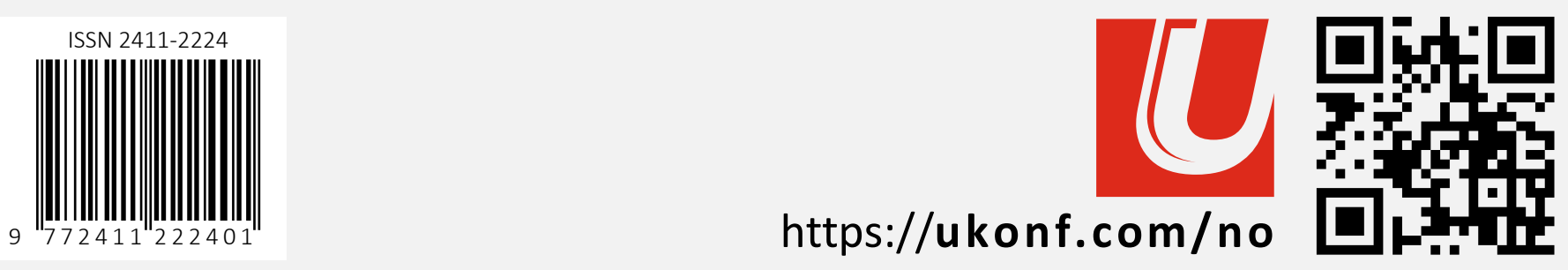


\section{Наука, образование, общество}

$2014 \cdot N$ 1 $(1)$

Выходит 4 раза в год

Свидетельство о регистрации средства массовой информации ЭЛ № ФС 77-56325 от 02.12.2013 2. выдано Федеральной службой по надзору в сфере связи, информационных технологий и массовых коммуникаций (Роскомнадзор)

Учредитель и издатель:

ООО «Консалтинговая компания Юком»

Главный редактор: Уляхин Т.М.

Адрес редакции: Россия, 392000, г. Тамбов, а/я 44

URL: https://ukonf.com/no

Информация об опубликованных статьях

предоставляется в РИНЦ (договор № 255-04/2015)

\section{Science, education, society}

$2014 \cdot \mathrm{N} 1(1)$

Issued 4 times a year

Registration Certificate of mass

media EL № FS 77-56325 from 12/02/2013

given by Federal service of supervision in the scope of communication, information technologies and mass media (Roskomnadzor)

Founder and Publisher: Consulting company Ukom Editor in Chief: Ulyahin T.M.

Address of Publisher:

Russia, 392000, Tambov, PO box 44

URL: https://ukonf.com/no

The information about published articles is given to the RISQ system (contract № 255-04/2015)

Статьи, поступающие в редакцию, рецензируются. Материалы публикуются в авторской редакции. За содержание и достоверность статей ответственность несут авторы. Мнение редакции может не совпадать с мнением авторов статей. При использовании и заимствовании материалов ссылка на издание обязательна. Издание основано в 2013 году. Усл. печ. л. 10,00.

\section{Редакционная коллегия}

Бажева Римма Чамаловна

Доктор химических наук, профессор, Кабардино-Балкарский государственный университет им. Х.М. Бербекова

г. Нальчик, ул. Чернышевского, 173

\section{Везиров Тимур Гаджиевич}

Доктор педагогических наук, профессор

Дагестанский государственный педагогический университет

2. Махачкала, пр. Г. Гамидова, 17

\section{Вышкин Ефим Григорьевич}

Доктор филологических наук, профессор, проректор Самарский государственный архитектурно-строительный университет

г. Самара, ул. Мологвардейская, 194

\section{Дыбина Ольга Витальевна}

Доктор педагогических наук, профессор, зав. кафедрой

Тольяттинский государственный университет

2. Тольятти, ул. Белорусская, 14

\section{Егорова Галина Ивановна}

Доктор педагогических наук, профессор, зав. кафедрой

Тюменский государственный нефтегазовый университет (филиал)

2. Тобольск, Зона Вузов, 9

\section{Зайнуллина Лилия Маратовна}

Доктор филологических наук, профессор, зав. кафедрой

Башкирский государственный университет

г. Уфа, ул. К. Маркса, 3/4

\section{Зенченко Светлана Вячеславовна}

Доктор экономических наук, профессор

Северо-Кавказский федеральный университет

2. Ставрополь, ул. Пушкина, 1

Карабеков Кадырбек Чолпонбаевич

Доктор философских наук, профессор

Российский государственный социальный университет (филиал)

Киргизия, г. Ош, ул. Карасуйская, 161

\section{Editorial board}

Bazheva Rima Chamalovna

Doctor of Chemical Sciences, Professor

Kabardino-Balkaria State University named H.M. Berbekov

Nalchik, Chernishevskiy st., 173

Vezirov Timur Gadjievich

Doctor of Pedagogic Sciences, Professor

Dagestan State Pedagogical University

Makhachkala, G. Gamidova ave., 17

Vyshkin Eefim Grigoryevich

Doctor of Philological Sciences, Professor, Vice-Rector

Samara State University of Civil Engineering

Samara, Mologvardeyskaya st., 194

\section{Dybina Olga Vitalievna}

Doctor of Pedagogical Sciences, Professor, head of Department

Togliatti State University

Togliatti, Belorusskaya st, 14

\section{Egorova Galina Ivanovna}

Doctor of Pedagogical Sciences, Professor, head of Department Tyumen State Oil and Gas University (branch)

Tobolsk, Zona Vuzov, 9

\section{Zaynullina Liliya Maratovna}

Doctor of Philological Sciences, Professor, head of Department, Bashkir State University

Ufa, K. Marks st., 3/4

Zenchenko Svetlana Vyacheslavovna

Doctor of Economics Science, Professor

North-Caucasian Federal University

Stavropol, Pushkin st., 1

Karabekov Kadirbek Cholponbaevich Doctor of Philosophical Sciences, Professor

Russian State Social University (branch)

Kyrgyzstan, Osh, Karasuyskaya st., 161 


\section{Редакционная коллегия}

Кожин Владимир Александрович

Доктор экономических наук, профессор, зав. кафедрой

Нижегородский институт менеджмента и бизнеса

2. Нижний Новгород, ул. Горная, 13

Левитес Дмитрий Григорьевич

Доктор педагогических наук, профессор

Мурманский государственный гуманитарный университет

2. Мурманск, ул. Егорова, 15

\section{Марченко Марина Николаевна}

Доктор педагогических наук, профессор, зав. кафедрой

Кубанский государственный университет

г. Краснодар, ул. Ставропольская, 149

\section{Пиджаков Александр Юрьевич}

Доктор юридических и исторических наук, профессор,

зав. кафедрой, Санкт-Петербургский государственный

университет гражданской авиации

г. Санкт-Петербург, ул. Пилотов, 38

Пирожков Геннадий Петрович

Доктор культурологии, профессор

Тамбовский государственный технический университет

г. Тамбов, ул. Советская, 106

\section{Ретюнских Лариса Тимофеевна}

Доктор философских наук, профессор

Московский государственный университет им. М.В. Ломоносова

2. Москва, Ленинские горы, 1

\section{Чернецов Владимир Иванович}

Доктор технических наук, профессор, зав. кафедрой

Московский государственный университет технологий и

управления им. К.Г. Разумовского (филиал)

2. Пенза, ул. Красная, 38

\section{Яковлева-Чернышева Анна Юрьевна}

Доктор экономических наук, доцент, проректор

Международный инновационный университет

2. Сочи, ул. Орджоникидзе, 10 A

\section{Авдеева Надежда Александровна}

Кандидат медицинских наук, профессор

Мордовский государственный университет им. Н.П. Огарёва

2. Саранск, ул. Ульянова, $26 \mathrm{~A}$

\section{Акулова Елена Федоровна}

Кандидат педагогических наук, доцент

Российский государственный социальный университет (филиал)

2. Тольяттии, ул. Ст. Разина, 78

\section{Болышева Надежда Николаевна}

Кандидат философских наук, доцент, директор филиала Сибирский государственный аэрокосмический университет им. М.Ф. Решетнева (филиал)

2. Зеленогорск, ул. Гагарина, 18

\section{Газизов Андрей Равильевич}

Кандидат педагогических наук

Донской государственный технический университет

2. Ростов-на-Дону, пл. Гагарина, 1

\section{Гонтарь Сергей Михайлович}

Кандидат искусствоведения, доцент, Краснодарский государственный университет культуры и искусств г. Краснодар, ул. 40 лет Победы, 33

\section{Дайрабаева Айжан Сериковна}

Кандидат экономических наук, первый проректор

Казахстанский инновационный университет

Казахстан, г. Семей, ул. Байсеитова, 5

\section{Демченко Зинаида Алексеевна}

Кандидат педагогических наук, доцент, Северный (Арктический) федеральный университет им. М.В. Ломоносова 2. Архангельск, Набережная Северной Двины, 17

\section{Editorial board}

Kozhin Vladimir Aleksandrovich

Doctor of Economics Science, Professor, head of Department

Nizhny Novgorod Institute of Management and Business

Nizhny Novgorod, Mountain st., 13

Lewites Dmitry Grigorievich

Doctor of Pedagogical Sciences, Professor

Murmansk State Humanities University

Murmansk, Egorov st., 15

Marchenko Marina Nikolaevna

Doctor of Pedagogical Sciences, Professor, head of Department

Kuban State University

Krasnodar, Stavropolskaya st., 149

Pidzhakov Aleksander Yurievich

Doctor of Juridical and Historical Sciences, Professor,

head of Department

St. Petersburg State University of Civil Aviation

St. Petersburg, Pilotov st., 38

Pirozhkov Gennadiy Petrovich

Doctor of Culturology, Professor

Tambov State Technical University

Tambov, Sovetskaya st., 106

\section{Retunskih Larisa Timofeevna}

Doctor of Philosophical Sciences, Professor

Moscow State University named M.V. Lomonosov

Moscow, Leninskie gory, 1

\section{Tchernetsov Vladimir Ivanovich}

Doctor of Technical Sciences, Professor, head of Department

Moscow State University of Technology and Management

named K.G. Razumovsky (branch)

Penza, Krasnaya st., 38

\section{Yakovleva-Chernysheva Anna Yurievna}

Doctor of Economic Sciences, associate Professor, vice Rector International Innovative University

Sochi, Ordzhonikidze st., $10 \mathrm{~A}$

Avdeeva Nadezhda Aleksandrovna

Candidate of Medical Sciences, Professor

Mordovia State University named N.P. Ogarev

Saransk, Ulyanov st., $26 \mathrm{~A}$

Akulova Elena Fyodorovna

Candidate of Pedagogical Sciences, associate Professor

Russian State Social University (branch)

Tolyatti, Stepan Razin st., 78

Bolysheva Nadezhda Nikolaevna

Candidate of Philosophical Sciences, associate Professor

Director of branch, Siberian State Aerospace University

named M.F. Reshetnev (branch)

Zelenogorsk, Gagarina st., 18

Gazizov Andrey Ravilevich

Candidate of Pedagogical Sciences

Don State Technical University

Rostov-on-Don, Gagarin sq., 1

Gontar Sergei Mikhailovich

Candidate of Art History, associate Professor

Krasnodar State University of Culture and Arts

Krasnodar, 40 Years of Victory st., 33

Dayrabaeva Aizhan Serikovna

Candidate of Economic Sciences, First Vice-Rector

Kazakhstan Innovation University

Kazakhstan, Semey, Baiseitova st., 5

Demchenko Zinaida Alekseevna

Candidate of Pedagogical Sciences, associate Professor

Northern (Arctic) Federal University named M.V. Lomonosov Arkhangelsk, Northern Dvina emb., 17 


\section{- Редакционная коллегия}

\section{Дружинина Анна Валентиновна}

Кандидат юридических наук, доцент, проректор

Международный инновационный университет

2. Сочи, ул. Орджоникидзе, $10 \mathrm{~A}$

\section{Зейнуллина Айгуль Жумагалиевна}

Кандидат экономических наук, зав. кафедрой

Государственный университет им. Шакарима

Казахстан, г. Семей, ул. Глинки, $20 \mathrm{~A}$

\section{Зёлко Александра Сергеевна}

Кандидат педагогических наук, доцент

Балтийский федеральный университет им. И. Канта

2. Калининград, ул. А. Невского, 14

\section{Киямова Ания Галиакбаровна}

Кандидат педагогических наук, доцент

Набережночелнинский институт социально-педагогических технологий и ресурсов

2. Набережные Челны, ул. Низамутдинова, 28

\section{Кононов Владимир Александрович}

Кандидат педагогических наук, доцент

Санкт-Петербургский Университет МВД России

2. Санкт-Петербург, ул. Летчика Пилютова, 1

\section{Кузнецов Евгений Геннадьевич}

Кандидат педагогических наук, доцент

Калининградский государственный технический университет

г. Калининград, ул. Молодежная, 6

\section{Новикова Ирина Викторовна}

Кандидат экономических наук, доцент, зав. кафедрой

Московская академия предпринимательства при

Правительстве Москвы (филиал)

2. Благовещенск, ул. Ленина, 27

\section{Полуянова Нина Васильевна}

Кандидат педагогических наук, зам. директора,

Заслуженный учитель РФ

Гимназия им. Н.Д. Лищмана

2. Тобольск, 7 мкрн, 54

\section{Савинова Людмила Юрьевна}

Кандидат педагогических наук, доцент, Российский государственный педагогический университет им. А.И. Герцена 2. Санкт-Петербург, наб. реки Мойки, 48

Саволайнен Галина Савельевна

Кандидат педагогических наук, доцент, зав. кафедрой

Красноярский государственный педагогический университет им. В.П. Астафьева

г. Красноярск, ул. А. Лебедевой, 89

\section{Смирнов Леонид Николаевич}

Кандидат архитектуры, профессор, зав. кафедрой, член Союза архитекторов России, Заслуженный работник Высшей школы РФ Уральская государственная архитектурно-художественная академия

2. Екатеринбург, К. Либкнехта, 23

\section{Султанова Нургуль Камильевна}

Кандидат педагогических наук, доцент

Государственный университет им. Шакарима

Казахстан, г. Семей, ул. Глинки, $20 \mathrm{~A}$

\section{Токпанов Еркин Аипович}

Кандидат географических наук, доцент

Жетысуский государственный университет им. И. Жансугурова Казахстан, г. Талдыкорган, ул. Жансугурова, 187

\section{Тюрин Александр Николаевич}

Кандидат географических наук, доцент

Оренбургский государственный педагогический университет

г. Оренбург, ул. Советская, 19

\section{Editorial board}

Druzhinina Anna Valentinovna

Candidate of Juridical Sciences, associate Professor, Vice Rector International Innovative University

Sochi, Ordzhonikidze st., $10 \mathrm{~A}$

Zeinullin Aigul Zhumagalievna

Candidate of Economic Sciences, head of Department

State University named Shakarim

Kazakhstan, Semey, Glinka st., 20 A

\section{Zelko Alexandra Sergeevna}

Candidate of Pedagogical Sciences, associate Professor

Baltic Federal University named I. Kant

Kaliningrad, A. Nevsky st., 14

\section{Chiamova Aniya Galiakbarovna}

Candidate of Pedagogical Sciences, associate Professor Naberezhnochelninsky Institute of Social and Pedagogical

Technologies and Resources

Naberezhnye Chelny, Nizamutdinov st., 28

\section{Kononov Vladimir Alexandrovich}

Candidate of Pedagogical Sciences, associate Professor

St. Petersburg University of the Russian Interior Ministry

St. Petersburg, Pilot Pilyutov st., 1

Kuznetsov Evgeniy Gennadyevich

Candidate of Pedagogical Sciences, associate Professor

Kaliningrad State Technical University

Kaliningrad, Molodegnaya st., 6

\section{Novikova Irina Viktorovna}

Candidate of Economic Sciences, associate Professor, head of Department, Moscow Academy of Business under the Government of Moscow (branch)

Blagoveschensk, Lenin st., 27

Poluyanova Nina Vasilyevna

Candidate of Pedagogic Sciences, deputy Director

Gymnasium named N.D. Litsman

Tobolsk, 7th distr., 54

\section{Savinova Lyudmila Yurievna}

Candidate of Pedagogical Sciences, associate Professor Russian State Pedagogical University named A.I. Herzen St. Petersburg, Moika emb., 48

Savolainen Galina Savelievna

Candidate of Pedagogical Sciences, associate Professor, head of Department

Krasnoyarsk State Pedagogical University named V.P. Astafiev Krasnoyarsk, A. Lebedeva st., 89

Smirnov Leonid Aleksandrovich

Doctor of Architecture, Professor, head of Department

Ural State Architectural Art of Academy

Ekaterinburg, K. Liebknecht st., 23

\section{Sultanova Nurgul Kamilevna}

Candidate of Pedagogical Sciences, associate Professor

State University named Shakarim

Kazakhstan, Semey, Glinka st., 20 A

\section{Tokpanov Erkin Aipovich}

Candidate of Geographical Sciences, associate Professor

Zhetysu state university named I. Zhansugurov

Kazakhstan, Taldykorgan, Zhansugurov st., 187

\section{Tyurin Alexander Nikolaevich}

Candidate of Geographical Sciences, associate Professor

Orenburg State Pedagogical University

Orenburg, Sovetskaya st., 19 


\section{Редакционная коллегия}

Хоронеко Светлана Евгеньевна

Кандидат биологических наук, доцент

Мордовский государственный университет им. Н.П. Огарёва 2. Саранск, ул. Ульянова, 26 А

\section{Худалов Марат Захарович}

Кандидат физико-математических наук, доцент, декан

Северо-Осетинский государственный университет

им. К.Л. Хетагурова

2. Владикавказ, ул. Ватутина, 44

\section{Шамрова Елена Александровна}

Кандидат медицинских наук, доцент

Мордовский государственный университет им. Н.П. Огарёва

2. Саранск, ул. Ульянова, $26 \mathrm{~A}$

\section{Юдина Наталья Михайловна}

Кандидат педагогических наук, доцент

Волжский институт строительства и

технологий (филиал) ВГАСУ

2. Волжский, ул. Ленина, 72

\section{Editorial board}

Horoneko Svetlana Evgenievna

Candidate of Medical Sciences, associate Professor

Ogarev Mordovia State University

Saransk, Ulyanov st., 26 A

Khudalov Marat Zakharovich

Candidate of Physical and Mathematical Sciences, associate

Professor, Dean

North Ossetian State University named K.L. Khetagurova

Vladikavkaz, Vatutin st., 44

\section{Shamrova Elena Aleksandrovna}

Candidate of Medical Sciences, associate Professor

Mordovia State University named N.P. Ogarev

Saransk, Ulyanov st., 26 A

Yudina Natalia Mikhailovna

Candidate of Pedagogical Sciences, associate Professor

Volzhsky institute of construction and

technologies (branch) VSACU

Volzhsky, Lenin st., 72 


\section{Содержание}

\section{ЭКОНОМИЧЕСКИЕ НАУКИ}

Зейнуллина А.Ж., Слямова 3.А.

Об актуальности аудита на современном этапе развития

Нечай А.А., Проточанская Ю.Ю., Котиков П.Е.

Анализ каналов утечки информации

Нечай А.А., Минухина Л.С., Котиков П.Е.

Финансовые риски при утечке информации

ПЕДАГОГИЧЕСКИЕ НАУКИ

Ажгихин С.Г., Селезнева Т.В.

Специфика проектирования жилого помещения с учетом потребностей и интересов

жильцов

Ажгихин С.Г., Лисишина О.А.

Специфика проектирования дизайна интерьера салона красоты

Берсенева Н.В.

Учебная дисциплина «Психология и педагогика» в системе подготовки студентов-

экономистов.

Волкова Е.В.

Использование современных информационных и инновационных технологий при обучении студентов теории и практике межкультурной коммуникации

Карпова А.Ю., Марченко М.Н.

Дизайн фирменного стиля молодежных центров Российской Федерации

Марченко М.Н., Ивашечкина Е.А.

Дизайн фирменного стиля компаний, специализирующихся на геолого-

геофизических изысканиях.

Марченко М.Н., Федосеева А.А.

Методика и методы предпроектного анализа при дизайн-проектировании

фирменного стиля студии ручной работы.

Марченко М.Н., Силищева Ю.В.

Дизайн-проект специализированного экспоцентра для крупногабаритных

экспонатов

Марченко М.Н., Гвоздева А.П.

Графическое оформление современного кулинарного журнала

\section{ПСИХОЛОГИЧЕСКИЕ НАУКИ}

Красновский В.Н., Баловнева Я.В., Басотина О.М., Кутузов Е.Л., Моруженко Н.А.

Изучение самосознания подростков мужского пола, поступающих в высшие военные учебные заведения Министерства обороны Российской Федерации

Красновский В.Н., Кутузов Е.Л., Теренин А.Е., Дурнов И.В., Моруженко Н.А.

Человек в современном информационном пространстве. 
Колосова М.В.

Вклад молодёжи Томской области в формирование стратегического ресурса регионов Сибири

Байбатырова Н.M.

Концептуальные особенности публицистики и литературной критики

М.Н. Эпштейна... 


\section{Contents}

Zeinullina A.Z., Slyamova Z.A.

On the relevance audit at the present stage of development.

Nechay A.A., Protochanska Yu.Yu., Kotikov P.E.

Analysis of the channels of leakage of information

Nechay A.A., Minuhina L.S., Kotikov P.E.

Financial risks of information leakage

Azhgikhin S.G., Selezneva T.V.

Specific features of the premises design which meets the needs and interests of tenants

Azhgikhin S.G., Lisishina O.A.

Specific features of the beauty shop interior design

Berseneva N.V.

Discipline «Psychology and pedagogy» in the training students of economics

Volkova E.V.

Use of modern information and innovative technologies while teaching theory and practice

of intercultural communication to university students.

Karpova A.Yu., Marchenko M.N.

Corporate identity design of youth centers in the Russian Federation

Marchenko M.N., Ivashechkina E.A.

Corporate Identity design of companies specializing in geological and geophysical

explorations.

Marchenko M.N., Fedoseyeva A.A.

Methodology and methods of the predesign analysis at design engineering of the corporate style of studio of handwork.

Marchenko M.N., Silischeva Yu.V.

Design project of a specialized expo-center for large-scale exhibits

Marchenko M.N., Gvozdeva A.P.

Graphic design of a modern cooking magazine

Krasnovsky V.N., Balovneva Y.V., Basotina O.M., Kutuzov E.L., Moruzenko N.A.

The study of self male adolescents coming in higher military educational institutions of the Ministry of defense of the Russian Federation.

Krasnovsky V.N., Kutuzov E.L., Terenin A.Ye., Durnov I.V., Moruzenko N.A.

People in the modern information space.

Kolosova M.V.

Contribution of young people of the Tomsk area to forming of strategic resource of regions of Siberia

Baybatyrova N.M.

Conceptual features of journalism and literary criticism M.N. Epstein 


\title{
Зейнуллина А.Ж., Слямова 3.А. Об актуальности аудита на современном этапе развития
}

\author{
Zeinullina A.Z., Slyamova Z.A. \\ On the relevance audit at the present stage of development
}

В статье раскрыты актуальность и сущность аудиторской деятельности. Рассмотрены цель и задачи аудита финансовой отчетности. Описаны этапы и процедуры аудита

Ключевые слова: аудит, аудитор, сопоставление, инвентаризация, опрос

\section{Зейнуллина Айгуль Жумагалиевна}

Кандидат экономических наук, зав. кафедрой Государственный университет им. Шакарима Респ. Казахстан, г. Семей, ул. Глинки, 20 A

Слямова Зауре Адильхановна

Старший преподаватель

Государственный университет им. Шакарима Респ. Казахстан, г. Семей, ул. Глинки, 20 A
The article deals with the relevance and the essence of auditing. Consider the purpose and objectives of the audit financial statements. Described audit steps and procedures

Key words: auditing, auditor, mapping, inventory, interview

\section{Zeinullina Aygul Zhumagalievna}

Candidate of Economic Sciences, head of the

department

Shakarim State University

Republic of Kazakhstan, Semey, Glinka St., 20 A

\author{
Slyamova Zaure Adilhanovna \\ Senior lecturer \\ Shakarim State University \\ Republic of Kazakhstan, Semey, Glinka St., 20 A
}

В условиях совершенствования управления и развития рыночной экономики усиливается роль и значение бухгалтерского учета. Формирование качественной информации о финансово-хозяйственной деятельности предприятия для объективного принятия управленческих решений является главной целью бухгалтерского учета. В современных условиях вопросы организации учета и аудита приобретают особую актуальность, поскольку финансовая устойчивость и финансовое положение предприятия во многом зависят от эффективности использования на предприятии его ресурсов [1]. Скорость и период оборачиваемости определяют эффективность использования ресурсов, чем быстрее они оборачиваются, тем выше скорость их оборота и меньше период их оборачиваемости, следовательно, эффективность их использования повышается, что положительно отражается на финансовом положении предприятия, его финансовых результатах, и соответственно происходит укрепление его финансовой устойчивости. В современных условиях на многих отечественных предприятиях успешно используется методика маржинального анализа, которая позволяет более экономно расходовать материальные, денежные, трудовые и другие ресурсы, способствует выявлению неиспользованных резервов, 
повышению эффективности управления процессом ценообразования. На предприятии огромное практическое значение имеет организация управленческого учета, особенности построения системы учета затрат и системы управления денежными потоками предприятия, оценка финансовых результатов, особенности формирования ценовой политики предприятия, оценка эффективности ее бизнеса и формирования системы внутреннего контроля, которые влияют на развитие предприятия. В современных условиях уделяется большое внимание повышению действенности учетной информации в управлении производством, рациональному использованию имеющихся ресурсов, снижению себестоимости продукции и повышению рентабельности производства и продаж. Для осуществления предпринимательской деятельности предприятию необходимо иметь ресурсы, которые необходимо разумно использовать. В процессе решения проблем должны быть использованы такие экономические рычаги, как экономическая заинтересованность и ответственность за эффективное использование ресурсов, а также проведение их анализа на основе применения прогрессивных методов и современных систем учета и аудита. Это позволит своевременно выявлять и оперативно устранять отрицательные явления, имеющие место на предприятии, в связи с этим возникает необходимость и важность дальнейшего изучения и совершенствования методологических и технологических основ организации учета и аудита.

Изучению организации учета и аудита посвящено много интересных и содержательных работ ведущих ученых Казахстана и стран ближнего зарубежья: Сейдахметовой Ф.С., Сатубалдина С.С., Дюсембаева К.Ш., Ажибаевой 3.Н., Ержанова М.С., Радостовца В.К., Ковалевой А.И., Соколова Я.С., Шеремета А.Д., Суйца В.П., Ткача М.В. и многих других исследователей.

Аудит представляет собой независимую экспертизу финансовой отчетности предприятия на основе проверки соблюдения порядка ведения бухгалтерского учета, соответствия хозяйственных и финансовых операций законодательству РК, полноты и точности отражения в финансовой отчетности деятельности предприятия, которая завершается составлением аудиторского заключения.

Сущность аудиторской деятельности заключается в том, что она является предпринимательской деятельностью аудиторских фирм или аудиторов, которые предлагают клиентам услуги по независимой проверке финансовой отчетности, платежно-расчетной документации, оказанию различных услуг и консультаций, ведению и восстановлению бухгалтерского учета, оценке активов и обязательств организации, составлению налоговой декларации, проведению экономического анализа финансово-хозяйственной деятельности.

В ходе аудиторской проверки финансовых отчетов устанавливается точность отражения в них финансового положения и результатов деятельности предприятия, соответствие ведения бухгалтерского учета установленным требованиям и критериям, соблюдение проверяемым предприятием действующего законодательства. Проверку достоверности отчетности предприятия, соблюдения действующего законодательства и, составление аудиторского заключения осуществляет независимый аудитор. 
Существует несколько определенных правил, касающихся деятельности независимых аудиторов:

- свободный выбор аудитора или аудиторской фирмы предприятием;

- договорные отношения между аудитором (аудиторской фирмой) и клиентом, позволяющие аудитору самому выбирать своего клиента и быть независимым от указаний каких-либо государственных органов;

- возможность отказать клиенту в выдаче аудиторского заключения до устранения отмеченных недостатков;

- невозможность аудиторской проверки при родственных или деловых отношениях с клиентом, превышающих договорные отношения по поводу аудиторской деятельности;

- запрещение аудиторам и аудиторским фирмам заниматься хозяйственной, коммерческой и финансовой деятельностью, не связанной с выполнением аудиторских, консультационных и других услуг, разрешенных законодательством.

Основная цель аудита финансовой отчетности - объективная оценка полноты, достоверности и точности отражения в отчетности активов, обязательств, собственных средств, финансовых результатов деятельности предприятия за определенный период, проверка соответствия принятой на предприятии учетной политики действующему законодательству и нормативным актам. Основная цель может дополняться задачами: выявления резервов лучшего использования финансовых ресурсов, анализом правильности исчисления налогов, разработкой мероприятий по улучшению финансового положения предприятия, оптимизации затрат и результатов деятельности, доходов и расходов.

Задачи, которые необходимо решить аудитору, для достижения цели:

- определить все ли активы и пассивы отражены в отчете;

- определить все ли документы использованы в отчете;

- определить насколько фактическая методика оценки имущества отклоняется от принятой при определении учетной политики предприятия.

Аудитор должен проверить полноту выполнения решений собственников предприятия об изменении объема уставного капитала, тождество данных синтетического и аналитического учета по счетам актива и пассива баланса, полноту отражения в отчетности дебиторской и кредиторской задолженности, соблюдение принятой на предприятии учетной политики, правильность отнесения доходов и расходов к отчетному периоду, обеспечение тождества данных аналитического учета оборотам и остаткам по счетам аналитического учета на первое число каждого месяца.

Цель профессии аудитора - работать в соответствии с нормами высокого профессионализма в целях достижения максимального уровня эффективности для удовлетворения потребностей общества. Это предполагает соблюдение четырех требований, а именно: достоверности, профессионализма, качества услуг и доверия.

Для достижения цели он должен действовать таким принципам:

- честность (аудитор должен быть честным при выполнении своих профессиональных обязанностей); 
- объективность (аудитор должен быть справедливым и не допускать, чтобы предрассудки, предвзятость и другие факторы оказывали влияние на объективность);

- профессиональная компетентность (аудитор, соглашаясь оказать услуги, должен быть уверен, что обладает достаточным уровнем профессиональной компетентности, знаний и навыков для выполнения данного задания, в противном случае должен воздержаться от их выполнения);

- конфиденциальность (аудитор не имеет права без согласия проверяемого субъекта разглашать информацию, полученную в ходе оказания профессиональных услуг, включая коммерческую тайну, за исключением случаев передачи результатов проверки собственнику или органу, назначившему проверку);

- профессиональное поведение (аудитор должен действовать в соответствии с хорошей репутацией профессии, воздерживаясь от поведения, дискредитирующего профессию);

- профессиональные стандарты (аудитор должен рассматривать профессиональные услуги согласно соответствующим профессиональным стандартам, принятым законодательными и нормативными актами. Аудиторы должны быть и являются свободными от любой заинтересованности, несовместимой с честью, объективностью и независимостью).

Главным принципом является принцип независимости. Как бы ни был компетентен аудитор, его мнение о качестве отчетности может быть оспорено, если он окажется в той или иной форме зависим от клиента. Поэтому аудитор и аудиторская фирма не должны иметь имущественных и иных интересов в проверяемом предприятии, родственных связей с клиентом.

MCA 200 «Цель и общие принципы, регулирующие аудит финансовой отчетности» - это установление стандартов в отношении целей и общих принципов, регулирующих аудит финансовой отчетности. Согласно кодексу этики профессиональных бухгалтеров, изданной Международной федерацией бухгалтеров аудитор при выполнении своих обязанностей руководствуется следующими этическими принципами: независимость, честность, объективность, профессиональная компетентность и должная тщательность, конфиденциальность, профессиональное поведение и соблюдение технических стандартов. В статье 3 Закона РК «Об аудиторской деятельности» приведены четыре основных принципа: независимость, объективность, профессиональная компетентность и конфиденциальность. Аудитор обязан проводить аудит в соответствии с международными стандартами аудита, так как он содержит основные принципы и необходимые процедуры, пояснительные и прочие материалы. Масштаб аудита - это аудиторские процедуры, необходимые в конкретных обстоятельствах для достижения цели аудита. Аудиторские процедуры определяются аудитором с учетом требований международных стандартов аудита, законодательно-нормативных актов, а также с учетом условий соглашения по аудиту и требований по представлению отчетности.

Объем аудита определяется в соответствии с условиями соглашения с клиентами, в соответствии с документами системы нормативного регулирова- 
ния аудиторской деятельности. Аудитор должен получить достаточное представление обо всех сторонах финансово-хозяйственной деятельности предприятия, об организации бухгалтерского учета и системе внутреннего контроля, для того чтобы правильно планировать проверку и получить данные, достаточные для составления объективного аудиторского заключения. Объем аудита определяется на первом этапе. На втором этапе осуществляется планирование аудита. Планировать следует на основе предварительного анализа проверяемого предприятия, оценки масштаба предстоящих работ и применяемого внутреннего контроля; необходимо определить процедуры, которые следует использовать в процессе проверки, целесообразность привлечения к работе экспертов, других аудиторов, вспомогательного персонала и планировать их деятельность, получив соглашение клиента. На третьем этапе производят оценку системы внутреннего контроля. Необходима для того, чтобы определить вероятность возникновения ошибок, влияющих на достоверность финансовой отчетности, в результате определяют содержание, масштаб и количество аудиторских процедур. На четвертом этапе собирают аудиторские доказательства. В ходе проверки аудитор собирает доказательства того, что, финансовая отчетность составлена в соответствии с действующим законодательством и нормами бухгалтерского учета и является достоверным. На пятом этапе аудитор составляет рабочие документы (ведомости, схемы), что является собственностью аудитора, но информация, содержащаяся в ней конфиденциальна и не подлежит разглашению без согласия клиента. На шестом этапе составляется аудиторское заключение и аудиторский отчет. В них излагаются итоги проверки и выводы. Составляются заключения с ограничениями, отрицательные заключения, а отказ от заключения должен быть обоснованным.

Информация, собранная и проанализированная аудитором, в ходе аудиторской проверки, служащая для формирования выводов аудитором, называются аудиторскими доказательствами.

Для обоснованного выражения своего мнения о достоверности финансовой отчетности аудитор получает достаточные для этого аудиторские доказательства в результате проведения соответствующего комплекса тестов контроля и процедур по существу, которые включают наблюдение или участие в инвентаризации, наблюдение за выполнением хозяйственных или бухгалтерских операций, устный опрос, получение письменных подтверждений, проверка документов, получаемых клиентом от третьих лиц, проверка документов, подготовленных организацией-клиентом, проверка арифметических расчетов, анализ.

Аудиторские процедуры включают тесты контроля и процедуры по существу. Процедуры по существу состоят из детальных тестов операций и сальдо счетов и аналитических процедур.

Аудиторские доказательства бывают внутренние, внешние и смешанные. Внутренние доказательства - это информация, полученная в устном и письменном виде от аудируемой организации. Внешние доказательства - это информация, взятая у третьих лиц (в письменном виде по письменному запросу аудируемой организации). Смешанные доказательства - это информация, по- 
лученная от аудируемой организации в письменном или устном виде и подтверждаемая третьей стороной в письменном виде. Аудиторские доказательства должны быть достоверными и достаточными. Достаточность определяют на основе оценки системы внутреннего контроля и величины аудиторского риска. Достаточность - это количественная мера аудиторских доказательств. Для составления объективного и обоснованного аудиторского заключения аудитор обязан собрать достаточное количество соответствующих доказательств. Соответствие является качественной мерой аудиторских доказательств. На профессиональное суждение о том, что является достаточным соответствующим аудиторским доказательством, влияют такие факторы:

- аудиторская оценка характера и уровня неотъемлемого риска на уровне финансовой отчетности, на уровне сальдо счетов и классов операций;

- характер систем бухгалтерского учета и внутреннего контроля, оценка риска контроля;

- существенность проверяемой статьи;

- опыт, приобретаемый в течение предыдущих аудитов;

- результаты аудиторских процедур, включая мошенничество или ошибки, которые могут быть обнаружены;

- источник и надежность имеющейся информации.

Достоверность письменных доказательств выше, чем устных. Достоверность доказательств, полученных самой аудиторской фирмой выше, чем тех, которые были предоставлены. Собранные аудиторские доказательства отражаются в рабочих документах аудитора.

Документальная проверка - это проверка документов и записей. Методы документального контроля, используемые при аудите активов:

- формальная проверка документов (правильность заполнения реквизитов, наличие неоговоренных исправлений, подчисток, дописок в тексте и цифр, подлинность подписей должностных и материально ответственных лиц);

- арифметическая проверка (правильность подсчетов в документах, правильность показанных итогов в первичных документах, учетных регистрах и отчетных формах);

- проверка документов по существу (законность и целесообразность хозяйственных операций, правильность отнесения операции на счета и включения в статьи).

Фактическая проверка - это осмотр или подсчет аудитором материальных активов (производственных запасных частей, денежных средств, ценных бумаг, основных средств), то есть инвентаризация. Инвентаризация проводится с целью обеспечения достоверности данных бухгалтерского учета и отчетности. Этот прием подтверждает фактическое наличие имущества и финансовых обязательств, дает точную информацию об их существовании и состоянии, оценке основных средств, материалов, готовой продукции. Инвентаризация это метод получения наиболее ценных и достоверных доказательств о реальности и точности статей актива баланса, фактов совершения хозяйственных операций [25]. В ходе аудиторской проверки аудиторы могут наблюдать за проведением инвентаризации, в результате чего правильно оценить надеж- 
ность системы бухгалтерского учета и действенность системы внутреннего контроля. До начала инвентаризации аудитор должен выяснить, как часто проводится инвентаризация, проверить документы о результатах предшествующих инвентаризаций, ознакомиться с номенклатурой и объемами товарно-материальных ценностей, выявить из них наиболее дорогостоящие, проанализировать систему их учета и контроля, выявить ее сильные и слабые стороны. Если аудитор наблюдает за проведением инвентаризации, то ему необходимо принять участие в выполнении контрольных измерений, изучить, имеются ли устаревшие, неиспользуемые или малоиспользуемые ценности, проверить, как хранятся запасы, принадлежащие третьим лицам, учитываются ли они отдельно в складском учете и в бухгалтерии на счетах, проверить реальность дебиторской и кредиторской задолженности. Проверка может производиться в двух направлениях: сверки учетных данных с фактическим наличием ценностей, и наоборот.

В большей части в жизни организаций участвуют третьи лица, от которых могут быть получены в письменном виде подтверждения информации, которая вызывает сомнение у аудитора. Например, при обнаружении подчисток и исправлений в банковских выписках запрашиваются их копии из банка. Заранее делается запрос от имени аудируемой организации представить информацию непосредственно аудиторской фирме.

Устный опрос - это метод сбора аудиторских доказательств. Проводится на всех стадиях аудита (в ходе предварительного ознакомления и для выяснения отдельных вопросов, возникающих при проверке). Результаты должны записываться в виде протокола или краткого конспекта. Для проведения опросов аудиторская фирма должна разработать специальные бланки с перечнями вопросов и местом для ответов. Протоколы, конспекты и заполненные бланки приобщаются к другим рабочим документам аудитора.

Документы бывают внутренние и внешние. Внутренние документы готовятся и обрабатываются самой аудируемой организацией. Официальные и обычные документы. Наиболее достоверны официальные документы (уставные документы, выписки банка, корешки чеков). Менее достоверными являются обычные документы (счета - фактуры поставщиков, договора с покупателями). Степень доверия к внутренним документам зависит от качества системы внутреннего контроля.

С помощью данной процедуры аудитор выявляет и изучает нетипичные статьи и события, имеющие отражение в учете. При выполнении этой процедуры аудитор выборочно проверяет первичные документы и их запись в регистрах синтетического и аналитического учета с использованием МСА 530 «Аудиторская выборка». Непрерывный, поэлементный просмотр первичных документов с целью найти что-либо нетипичное.

Пересчет - проверка математической точности расчетов. Специальная проверка - привлечение специалиста с узкой специализацией. Аудиторы могут использовать метод встречных проверок. Проводится сплошная и выборочная проверка. Аналитическая процедура - это анализ и оценка полученной аудитором информации, исследование важных финансовых и экономических показа- 
телей аудируемой организации с целью выявления необычных и неверно отраженных в бухгалтерском учете хозяйственных операций и выявления причин таких ошибок и искажений.

Аналитические процедуры используются на стадии предварительного планирования до заключения договора на аудиторскую проверку, обычно в форме экспресс-анализа, при составлении программы аудиторской проверки, когда изучается отчетность организации - клиента и определяются участки, на которые следует обратить особое внимание, и в ходе самой аудиторской проверки. Аналитические процедуры помогают выявить степень деловой активности организации, зоны преднамеренных ошибок в отчетности организации, оценить перспективы ее функционирования в будущем, сократить детализированное тестирование на основной стадии аудита.

Информационную базу аудита представляют данные бухгалтерского учета и отчетности. К аналитическим процедурам относят:

- сопоставление остатков по счетам за различные учетные периоды;

- сопоставление показателей финансовой отчетности с запланированными (прогнозными), указанными в программах, бизнес-планах, сметах;

- сопоставление полученных в отчетном периоде соотношений между различными статьями отчетности с аналогичными соотношениями прошлых периодов;

- сопоставление финансовой и нефинансовой информации (например, объема выпуска продукции в денежных и натуральных единицах);

- сопоставление финансовых показателей и коэффициентов со среднеотраслевыми значениями.

Анализ финансовых коэффициентов заключается в сравнении их значений с базисными величинами и в изучении их динамики за отчетный период и за ряд лет.

Для обеспечения достоверности данных бухгалтерского учета и финансовой отчетности предприятие обязано проводить инвентаризацию имущества и обязательств, в ходе которой проверяются и документально подтверждаются их наличие, состояние и оценка. Инвентаризация имущества и обязательств является одной из важнейших процедур в бухгалтерском учете. Инвентаризации подлежит все имущество независимо от его места нахождения и все виды финансовых обязательств. Кроме того, инвентаризации подлежат материально-производственные запасы и другие виды имущества, не принадлежащие предприятию, но числящиеся в бухгалтерском учете, то есть находящиеся на ответственном хранении, арендованные, полученные для переработки, а также имущество, не учтенное по каким-либо причинам. Инвентаризация проводится по его местонахождению и материально ответственным лицам. Основная цель инвентаризации - выявление фактического наличия имущества, сопоставление фактического наличия имущества с данными бухгалтерского учета; проверка полноты отражения в учете обязательств [2].

Инвентаризация проводится не менее одного раза в год. Количество инвентаризаций в отчетном году, дата их проведения, перечень имущества и финансовых обязательств, проверяемых при каждой из них, устанавливаются ру- 
ководством организации, за исключением случаев, когда проведение инвентаризации обязательно.

Проведение инвентаризации обязательно в следующих случаях:

- при передаче имущества предприятия в аренду, при выкупе, продаже, а также в случаях, предусмотренных законодательством при преобразовании государственного предприятия;

- на день приемки-передачи дел при смене материально ответственных лиц;

- при выявлении фактов хищения, злоупотребления или порчи имущества;

- в случаях стихийного бедствия или чрезвычайных ситуаций, вызванных экстремальными условиями;

- при реорганизации или ликвидации предприятия до составления разделительного (ликвидационного) баланса;

- в других случаях, предусмотренных законодательством РК.

Для проведения инвентаризации на предприятии создается постоянно действующая комиссия. При большом объеме работ для одновременного проведения инвентаризации имущества и финансовых обязательств создаются рабочие инвентаризационные комиссии. При малом количестве работ и наличии на предприятии ревизионной комиссии проведение инвентаризации допускается возлагать на нее. Персональный состав постоянно действующих и рабочих инвентаризационных комиссий утверждает руководитель предприятия. Приказ, распоряжение, постановление о составе комиссии регистрируют в книге контроля за выполнением приказов о проведении инвентаризации. В состав инвентаризационной комиссии включаются представители администрации, работники бухгалтерии, другие специалисты (товароведы, технологи, инженеры, механики, экономисты). В состав инвентаризационной комиссии можно включать представителей службы внутреннего аудита предприятия, независимых аудиторских фирм. Отсутствие хотя бы одного члена комиссии, при проведении инвентаризации, служит основанием для того, чтобы признать результаты инвентаризации, недействительными. Инвентаризационная комиссия обеспечивает полноту и точность внесения в описи данных о фактических остатках основных средств, товаров, сырья, материалов, денежных средств, другого имущества, финансовых обязательств, а также правильность оформления результатов инвентаризации.

До начала проверки фактического наличия имущества инвентаризационной комиссии следует получить последние на момент инвентаризации приходные и расходные документы или отчеты о движении материальных ценностей и денежных средств. Материально ответственные лица дают расписки о том, что к началу инвентаризации все расходные и приходные документы на имущество сданы в бухгалтерию или переданы комиссии, и все ценности, поступившие под их ответственность, оприходованы, а выбывшие, списаны в расход. Аналогичные расписки дают лица, имеющие подотчетные суммы на приобретение или доверенность на получение имущества. Фактическое наличие имущества при инвентаризации определяется инвентаризационной ко- 
миссией путем обязательного подсчета, взвешивания, обмера. Проверка фактического наличия имущества производится при обязательном участии материально ответственных лиц.

Сведения о фактическом наличии имущества и реальности учетных финансовых обязательств записываются в инвентаризационные описи или акты инвентаризации не менее, чем в двух экземплярах. Инвентаризационные описи могут быть заполнены с использованием средств вычислительной техники или ручным способом. Наименование ценностей и объектов, их количество указывают в описях по номенклатуре и в единицах измерения, принятых в учете. На каждой странице описи указывают прописью число порядковых номеров материальных ценностей и общий итог количества в натуральных показателях, записанных на данной странице, вне зависимости от того, в каких единицах измерения, штуках, килограммах, метрах эти ценности показаны. На последней странице описи должна быть сделана отметка о проверке цен, таксировка и подсчет итогов за подписями лиц, производивших эту проверку. Исправление ошибок производится во всех экземплярах описей путем зачеркивания неправильных записей и проставления над зачеркнутыми правильных записей, исправления должны быть оговорены и подписаны всеми членами инвентаризационной комиссии и материально-ответственными лицами. В описях не допускается оставлять незаполненные строки, на последних страницах незаполненные строки прочеркиваются. Описи подписывают все члены инвентаризационной комиссии и материально ответственные лица. В конце описи материально ответственные лица дают расписку, подтверждающую проверку комиссией имущества в их присутствии, об отсутствии к членам комиссии каких-либо претензий и принятия перечисленного в описи имущества на ответственное хранение. В случае проверки фактического наличия имущества при смене материально ответственных лиц, принявшее имущество, расписывается в описи в получении, а сдавший - в сдаче этого имущества. На имущество, находящееся на ответственном хранении, арендованное или полученное для переработки, составляются отдельные описи. При окончании инвентаризации могут проводиться контрольные проверки правильности проведения инвентаризации. Их следует проводить с участием членов инвентаризационных комиссий и материально ответственных лиц обязательно до открытия склада, где проводилась инвентаризация. Результаты контрольных проверок правильности проведения инвентаризаций оформляются актом и регистрируются в книге учета контрольных проверок проведения инвентаризации. В межинвентаризационный период на предприятии с большой номенклатурой ценностей могут проводиться выборочные инвентаризации материальных ценностей в местах их хранений и переработки. Контрольные проверки правильности проведения инвентаризации и выборочные инвентаризации, проводимые в межинвентаризационный период, осуществляются инвентаризационными комиссиями по распоряжению руководства предприятия. Сличительные ведомости составляются по имуществу, при инвентаризации которого выявлены отклонения от учетных данных. В сличительных ведомостях отражаются результаты инвентаризации, то есть расхождения между показателя- 
ми по данным бухгалтерского учета и по данным инвентаризационных описей. Суммы излишков и недостач товарно-материальных ценностей в сличительных ведомостях указываются в соответствии с их оценкой в бухгалтерском учете. Для оформления результатов инвентаризации могут применяться единые регистры, в которых объединены показатели инвентаризационных описей и сличительных ведомостей. На ценности, не принадлежащие предприятию, но числящиеся в бухгалтерском учете, то есть находящиеся на ответственном хранении, арендованные, полученные для переработки, составляются отдельные сличительные ведомости, они могут быть составлены ручным способом или с применением вычислительной техники. Если в ходе инвентаризации выявлены расхождения фактического наличия имущества с данными бухгалтерского учета, то они регулируются в следующем порядке:

- основные средства, материальные ценности, денежные средства и другое имущество, оказавшиеся в излишке, приходуются, а соответствующие суммы зачисляются на финансовые результаты предприятия; при этом необходимо установить причины возникновения излишка;

- естественная убыль ценностей в пределах норм, утвержденных нормативно-правовыми актами, списывается распоряжением руководства предприятия; при этом нормы естественной убыли могут предъявляться только в случаях выявления недостач по факту;

- убыль ценностей в пределах установленных норм определяется после зачета недостач излишками по пересортице; если после зачета по пересортице, проведенного в установленном порядке, была установлена недостача ценностей, то нормы естественной убыли применяются только по тому наименованию ценностей, по которому установлена недостача; при отсутствии норм убыль необходимо рассматривать как недостачу сверх норм;

- недостачи материальных ценностей, денежных средств и другого имущества, а также порча сверх норм естественной убыли относятся на счет виновных лиц; в тех случаях, когда виновники не установлены или во взыскании с виновных лиц отказано судом, убытки от недостачи имущества и его порчи списываются на финансовые результаты предприятия.

В документах, представляемых для оформления списания недостач ценностей и порчи сверх норм естественной убыли, должны быть решения судебных или следственных органов, подтверждающие отсутствие виновных лиц, отказ о взыскании ущерба с виновных лиц, заключение о факте порчи ценностей, полученное от отдела технического контроля или соответствующих специализированных организаций, например, инспекций по качеству. Взаимный зачет излишков и недостач в результате пересортицы может быть допущен только в виде исключения за один и тот же проверяемый период, у одного и того же проверяемого лица, в отношении товарно-материальных ценностей одного и того же наименования в тождественных объемах. 0 допущенной пересортице материально ответственное лицо представляет подробное объяснение инвентаризационной комиссии. Результаты инвентаризации должны быть отражены в учете и отчетности того месяца, в котором была закончена инвентаризация, а при годовой инвентаризации - в годовой отчетности пред- 
приятия. Данные результатов инвентаризаций, проведенных в отчетном году, обобщаются в ведомости учета результатов, выявленных при инвентаризации. Организация учета краткосрочных активов в соответствии с действующим законодательством Республики Казахстан по бухгалтерскому учету и отчетности, международными стандартами финансовой отчетности способствует правильному формированию информации в финансовой отчетности. На основании такой информации проводится аналитическая работа на предприятии относительно эффективности использования краткосрочных активов, в результате представляется возможным принятие оптимальных управленческих решений по повышению эффективности их использования с целью улучшения результатов деятельности предприятия в целом.

Аудит на предприятии проводится в определенной последовательности. В процессе аудиторской проверки используется подход «от общего к частному». Аудит проводится поэтапно. В начале аудиторской проверки аудитор знакомится с предприятием, оценивает его экономическую среду, знакомится с отчетностью, состоянием бухгалтерского учета и направлениями деятельности предприятия; заключает договор на аудиторскую проверку, составляет план и программу аудита, изучает учредительные документы и другие документы, а именно: протоколы общих собраний, приказы директора, проверяет отсутствие противоречий с учредительными документами; изучает отчетности предприятия, производит счетную проверку показателей отчетных форм, проводит логический анализ показателей; уточняет и корректирует план и аудиторскую программу; проводит аудит показателей отчетности; подписывает аудиторское заключение и акт приемки работ по договору об аудиторской проверке. Все показатели всех форм финансовой отчетности должны быть взаимоувязаны между собой, поэтому в процессе аудита показателей финансовой отчетности необходимо, чтобы были осуществлены:

- проверка Главной книги (соответствие записей в отчетных формах остаткам по счетам в Главной книге);

- проверка правильности отнесения затрат на себестоимость продукции;

- проверка доходов от реализации продукции;

- проверка доходов и расходов от прочей реализации;

- проверка доходов и расходов от внереализационных операций;

- проверка порядка начисления и выплаты заработной платы;

- проверка порядка накопления и использования прибыли;

- проверка порядка ведения кассовых операций;

- проверка учета, оприходования и отпуска в производство материальных ценностей;

- проверка правильности начисления и своевременности уплаты налогов;

- проверка правильности расчетов и своевременности уплаты сборов, отчислений и обязательных платежей в бюджет и во внебюджетные фонды;

- проверка расчетов с дебиторами и кредиторами;

- подготовка аудиторского заключения;

- ознакомление с неопределенными обязательствами;

- обзор выполнения плана проведения аудита и аудиторских процедур. 
По результатам деятельности аудируемого предприятия, составляется аудиторское заключение, которое подтверждает или не подтверждает, то, что финансовая отчетность предприятия правильно отражает его финансовое положение, прибыль и убытки, движение денежных средств, а бухгалтерский учет отвечает требованиям законодательных и нормативных актов бухгалтерского учета.

Аудиторское заключение должно подтвердить, что:

- финансовая отчетность подготовлена добросовестно, на основе достоверных и объективных данных бухгалтерского учета;

- бухгалтерский учет соответствует установленным принципам и требованиям, учетная политика предприятия выбрана правильно;

- своевременно и полностью внесены налоги и другие обязательные платежи;

- в приложениях и пояснениях к отчету, соответствующим образом, раскрыты все вопросы, имеющие отношение к финансовой отчетности;

- внутренний контроль надежно подтверждает эффективность и целесообразность хозяйственных операций;

- данные финансовой отчетности не противоречат известным аудитору сведениям.

Проверка правильности составления бухгалтерского баланса должно быть основано на следующих основных моментах:

- данные статей баланса на начало периода соответствуют данным баланса за предшествующий период;

- данные статей баланса на конец отчетного периода обоснованы результатами инвентаризации;

- суммы статей баланса по расчетам с финансовыми, налоговыми органами, учреждениями банков согласованы с ними и тождественны;

- данные заключительного баланса соответствуют оборотам и остаткам по счетам Главной книги на конец отчетного года;

- данные балансов на начало и конец года сопоставимы.

Результаты аудита оказывают положительное влияние на развитие любого предприятия, так как они служат основой для принятия оптимальных управленческих решений в бизнесе.

\section{Список литературы:}

1. Стратегия экономического развития Казахстана до 2030 года.

2. Дюсембаев К.Ш. Аудит и анализ финансовой отчетности: Учебное пособие. Алматы: ҚаржыҚаражат, 2010.

\section{References:}

1. The strategy of economic development of Kazakhstan until 2030.

2. Dyusembaev KS Auditing and financial reporting analysis: Textbook. Almaty: Karzhy-Қarazhat 2010.

\footnotetext{
(C) 2014, Зейнуллина А.Ж., Слямова 3.А. Об актуальности аудита на современном этапе развития
}

\author{
(C) 2014, Zeinullina A.Z., Slyamova Z.A. \\ On the relevance audit at the present stage of \\ development
}


DOI: 10.17117/no.2014.01.022

Поступило в редакцию: 25.11.2014

vka@mil.ru

\title{
Нечай А.А., Проточанская Ю.Ю., Котиков П.Е. Анализ каналов утечки информации
}

\author{
Nechay A.A., Protochanska Yu.Yu., Kotikov P.E. \\ Analysis of the channels of leakage of information
}

Статья посвящена актуальной проблеме, совершенствованию средств защиты информации в экономических системах. Сегодня информация играет существенную роль в жизни любой компании. Сохранность информации приобретает определяющее значение. В статье рассмотрены каналы утечки информащии, выполнен анализ их особенностей, возможностей закрытия каналов утечки. Показано, как одним из наиболее эффективных способов борьбы с сетевыми угрозами, в том числе с программными закладками, становится совершенствование методов и средств контроля доступа к сети Ключевые слова: информация, утечка информации, каналы утечки информации, физические каналы утечки информащии, технические каналы утечки информации, программный червь, программная закладка

\section{Нечай Александр Анатольевич}

Преподаватель

Военно-космическая академия им. А.Ф. Можайского г. Санкт-Петербург, ул. Ждановская, 13

\section{Проточанская Юлия Юрьевна}

Курсант

Военно-космическая академия им. А.Ф. Можайского 2. Санкт-Петербург, ул. Ждановская, 13

\section{Котиков Павел Евгеньевич}

Кандидат технических наук, доцент

Военно-космическая академия им. А.Ф. Можайского

2. Санкт-Петербург, ул. Ждановская, 13
The article is devoted to the urgent problem of improving the means of information protection in economic systems. Today, information plays a significant role in the life of any company. The security of information becomes crucial. In the article the channels of information leakage, the analysis of their features, capabilities closure leakage channels. Shows how one of the most effective ways of dealing with network threats, including software bookmarks, is the improvement of methods and tools to control access to the network

Key words: information, information leakage, leakage of information, physical-ski channels of information leakage, technical channels of information leakage, software worm, software tab

\section{Nechay Alexander Anatolievich \\ Teacher}

Military space Academy Alexander Mozhaisky

St. Petersburg, Zhdanov st., 13

\section{Protochanska Yulia Yurievna \\ Cadet}

Military space Academy Alexander Mozhaisky

St. Petersburg, Zhdanov st., 13

\section{Kotikov Pavel Evgenievich}

Candidate of Technical Sciences, associate Professor Military space Academy Alexander Mozhaisky St. Petersburg, Zhdanov st., 13

Все каналы утечки данных можно разделить на косвенные и прямые. Косвенные каналы не требуют непосредственного доступа к техническим средствам информационной системы. Прямые, соответственно требуют доступа к аппаратному обеспечению и данным информационной системы.

Примеры косвенных каналов утечки: 
- Кража или утеря носителей информации, исследование не уничтоженного мусора;

- Дистанционное фотографирование, прослушивание;

- Перехват электромагнитных излучений.

Примеры прямых каналов утечки:

- Инсайдеры (человеческий фактор). Утечка информации вследствие несоблюдения коммерческой тайны;

- Прямое копирование.

Каналы утечки информации можно также разделить по физическим свойствам и принципам функционирования:

- акустические - запись звука, подслушивание и прослушивание;

- акустоэлектрические - получение информации через звуковые волны с дальнейшей передачей ее через сети электропитания;

- виброакустические - сигналы, возникающие посредством преобразования информативного акустического сигнала при воздействии его на строительные конструкции и инженерно-технические коммуникации защищаемых помещений;

- оптические - визуальные методы, фотографирование, видео съемка, наблюдение;

- электромагнитные - копирование полей путем снятия индуктивных наводок;

- радиоизлучения или электрические сигналы от внедренных в технические средства и защищаемые помещения специальных электронных устройств съема речевой информации “закладных устройств”, модулированные информативным сигналом;

- материальные - информация на бумаге или других физических носителях информации

1. Физические каналы утечки информации

Необходимость совершенствования средств физической защиты различных носителей информации является одной из главных задач любого объекта, будь то отдельно взятый индивид, или же некоторая организация. По статистике, главным источником утечки информации является человек. Для получения злоумышленником информации используются:

- сознательные действия сотрудников, обусловленные инициативным сотрудничеством с другой фирмой; продажей информации за взятку, под угрозой шантажа, в виде мести; переход на другую фирму на более высокую оплату (так называемая «кража мозгов»);

- обман (например, за счет создания ложной фирмы, в которую заманивают специалиста на собеседование, беседуют, выуживают сведения и затем отказывают в приеме);

- особенности характера сотрудника, например, его болтливость, желание показать себя более компетентным;

- слабое знание и невыполнение требований по защите информации и т.д. 
Документы и публикации являются также одним из важных возможных каналов утечки информации. Документ имеет определенные этапы жизни: составление, оформление, размножение, пересылка, использование, хранение и уничтожение. На любом этапе возможна утечка информации.

Для уменьшения возможности утечки информации руководство организации предпринимает следующие действия:

- разработка перечня документов с грифом «Коммерческая тайна» (этот термин обозначает информацию, которая позволяет получать предприятию большую прибыль по сравнению с конкурентом);

- уточнение списка лиц, допускаемых к работе с документами;

- организация учета входящих, исходящих документов и правил работы с ними;

- определение правил хранения (инвентарный учет, номенклатура дел, наличие сейфов и т. д.) документов;

- определение правил уничтожения документов.

2. Технические каналы утечки информации

Для обеспечения технической деятельности компании или организации широко используются телефоны, радиотелефоны, компьютеры, принтеры, дисплеи, клавиатура, обычный речевой обмен информацией и т.д. Потеря информации возможна по акусто-преобразовательным, электромагнитным, визуальным и другим каналам.

Для нелегального съёма информации используются различные технические средства. Информация с объекта поступает злоумышленнику по следующим физическим каналам: акустическим каналам; вибрационному каналу колебаний конструкций здания; электромагнитным каналам; телефонным каналам; электросетевым каналам; визуальным каналам.

В зависимости от физической природы возникновения информационных сигналов, а также среды их распространения и способов перехвата сообщения, технические каналы утечки можно разделить на:

1) Электромагнитные, электрические и параметрические (для телекоммуникационной информации). Примерами вмешательства злоумышленника с использованием такого рода каналов являются перехват побочных электромагнитных излучений; перехват побочных электромагнитных излучений на частотах работы высокочастотных генераторов; перехват побочных электромагнитных излучений на частотах самовозбуждения усилителей низкой частоты.

2) Воздушные (прямые акустические), вибрационные (виброакустические), электроакустические, оптико-электронные и параметрические (для речевой информации);

На основании обработки данных по эксплуатации прослушивающих устройств крупными фирмами (2010 год) были сделаны следующие выводы: для снятия информации чаще всего используется электромагнитный канал (61\%) с внедрением на объект "жучков", затем телефонный канал (15\%) и далее проводные каналы и диктофоны (13\%). Акустический канал с применением направленных микрофонов, вибрационный и электросетевой каналы используются редко. 
КАHАI

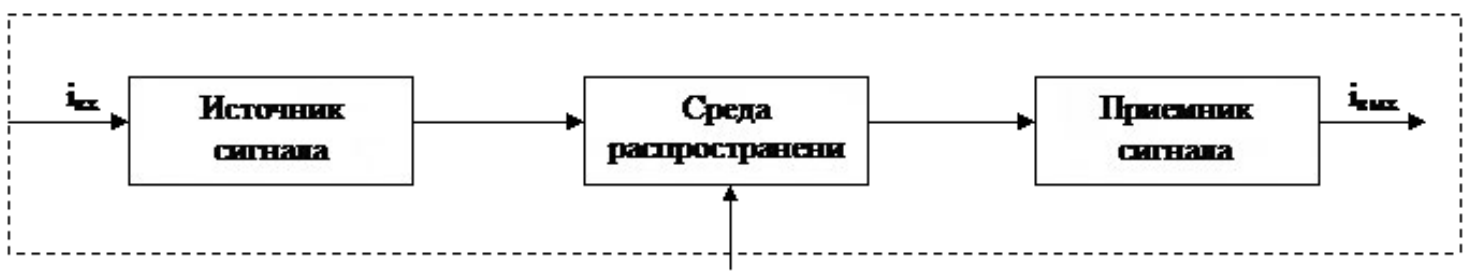

Рис. 1. Типовая структура канала передачи информации

В общем виде под техническим каналом утечки информации понимают совокупность 1) источника опасного сигнала, 2) среды распространения - носителя опасного сигнала, 3) средства технической разведки. На рисунке 1 представлена обобщенная типовая структура канала передачи информации.

На вход канала поступает информация в виде первичного сигнала івх. Первичный сигнал поступает с некоторого носителя информации или с выхода предыдущего канала. В качестве источника сигнала выступают:

- объект наблюдения, отражающий электромагнитные и акустические волны,

- объект наблюдения, излучающий собственные (тепловые) электромагнитные волны в оптическом и радиодиапазонах,

- передатчик функционального канала связи,

- источник опасного сигнала (т.е. сигнала, который содержит информацию с ограниченным доступом),

- источник акустических волн, модулированных информацией.

Так как информация от источника поступает на вход канала на языке источника (в виде буквенно-цифрового текста, символов, знаков, звуков, сигналов и т. д.), то передатчик производит преобразование этой формы представления информации в форму, обеспечивающую запись ее на носитель информации, соответствующий среде распространения. В общем случае он выполняет следующие функции:

- создает (генерирует) поля (акустическое, электромагнитное) или электрический ток, которые переносят информацию;

- производит запись информации на носитель (модуляцию информационных параметров носителя);

- усиливает мощность сигнала (носителя с информацией);

- обеспечивает передачу (излучение) сигнала в среду распространения в заданном секторе пространства.

- Приемник выполняет функции, обратные функциям передатчика. Он производит следующие действия:

- выбор (селекцию) носителя с нужной получателю информацией;

- усиление принятого сигнала до значений, обеспечивающих съем информации;

- съем информации с носителя (демодуляцию, декодирование);

- преобразование информации в форму сигнала, доступную получателю (человеку, техническому устройству), и усиление сигналов до значений, необходимых для безошибочного их восприятия [3]. 
Зона, в которой возможны перехват (с помощью разведывательного приёмника), побочных электромагнитных излучений и последующая расшифровка содержащийся в них информации, называется опасной зоной.

Как любой канал связи, канал утечки информации характеризуется следующими основными показателями: пропускной способностью, дальностью передачи информации.

Пропускная способность канала связи оценивается количеством информации, передаваемой по каналу в единицу времени с определенным качеством.

Перехват информационных сигналов по электрическим каналам утечки возможен путём непосредственного подключения к соединительным линиям вспомогательных технических средств и систем (это информационные системы, размещенные в помещениях обработки конфиденциальной информации) и посторонним проводникам. Для этих целей используют специальные средства радио- и радиотехнической разведки, а также специальная измерительная аппаратура.

Электронные устройства перехвата информации часто называют аппаратными закладками. Они представляют собой мини-передатчики, излучение которых модулируется информационным сигналом. Перехваченная с помощью закладных устройств информация непосредственно передаётся по радиоканалу или сначала записывается на специальное запоминающее устройство, а уже затем по команде передаётся на запросивший её объект.

В воздушных (прямых акустических) технических каналах утечки информации средой распространения акустических сигналов является воздух.

Звуковые волны оказывают переменное давление на предметы, расположенные на их пути, вызывая механические колебания в твердом теле со звуковой частотой. В отдельных конструкциях эти колебания могут передаваться на значительные расстояния, почти не затухая, и вновь излучаться в воздух, как слышимый воздушный звук. Особенно хорошо излучают звук легкие строительные конструкции с большой площадью поверхности. Передаваемый звук носит название "структурный звук".

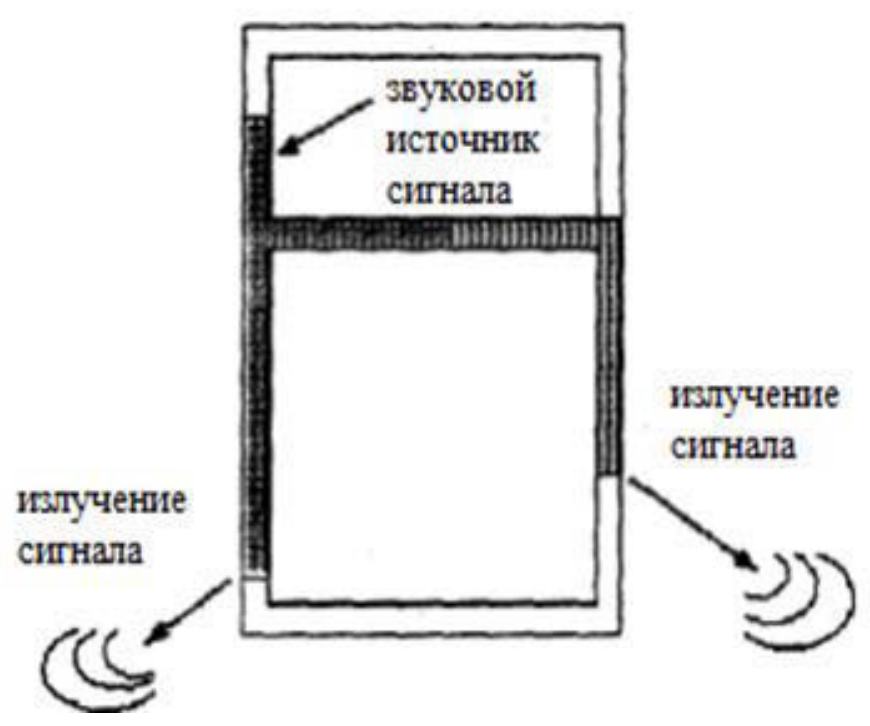

Рис. 2. Возникновение акустического канала утечки 
Наиболее возможные каналы передачи структурного звука - стены, трубопроводы, каналы воздушной вентиляции помещений и т.д. Таким образом, злоумышленник, находясь даже на значительном расстоянии, может получить желаемую звуковую информацию. На рисунке 2 приведен пример возникновения канала утечки за счет сформированного структурного звука в стенах и перекрытиях здания.

Для перехвата акустической (речевой) информации используют следующие устройства:

- портативные диктофоны и проводные микрофонные системы скрытой звукозаписи;

- направленные микрофоны;

- акустические радиозакладки (передача по радиоканалу);

- акустические сетевые закладки (передача информации по сети питания 220 B);

- акустические инфракрасные-закладки (передача информации по оптическому каналу в инфракрасном диапазоне длин волн);

- акустические телефонные закладки (передача информации по телефонной линии на высокой частоте);

- акустические телефонные закладки типа “телефонное ухо” (передача информации по телефонной линии на низкой частоте).

В вибрационных (виброакустических) технических каналах утечки информации средой распространения акустических сигналов являются элементы конструкций зданий, сооружений (стены, потолки, полы), трубы водоснабжения, канализации и другие твёрдые тела. Воздушные волны человеческой речи воздействуют на строительные конструкции и приводят к колебаниям стен, стекол, батарей и т.д. Для съема информации со стен используется электронные стетоскопы, для съема информации со стекла - лазерные системы, для съема информации с воды трубопроводов - гидроакустические преобразователи. Распознавание информации зависит от материала конструкций, толщины конструкций, от шумов, образующихся в конструкции, от движения людей, транспорта, вибрации.

Данный канал утечки не имеет деконспирационных признаков, и, следовательно, представляется затруднительным технически определить, происходит ли утечка информации по этому каналу. Специалисты осуществляют оценку возможности утечки информации на основании изучения архитектурностроительной документации на определенную часть объекта с последующей проверкой выводов с помощью стетоскопов. Если оказывается, что такой канал утечки возможен, то встаёт задача закрытия этого канала.

Для закрытия канала целесообразно применять искусственные источники помех - системы виброакустического зашумления (рисунок 3). Она состоит из генератора шума Г, формирующего помеху в диапазоне частот 0,2 - 5,0 кГц; усилителя мощности УМ, включаемого устройством управления УУ, которое включается голосом или вручную, и вибратора Вб (электромеханического преобразователя), обеспечивающего преобразование электрического сигнала в механические колебания конструкции. Генератор создает шум, который пода- 
ется на усилитель мощности. Сигналом с устройства управления включается усилитель мощности, и сигнал с него поступает на вибратор. Вибратор начинает работать, и появляются колебания стены, которые зашумляют колебания стены от акустического сигнала.

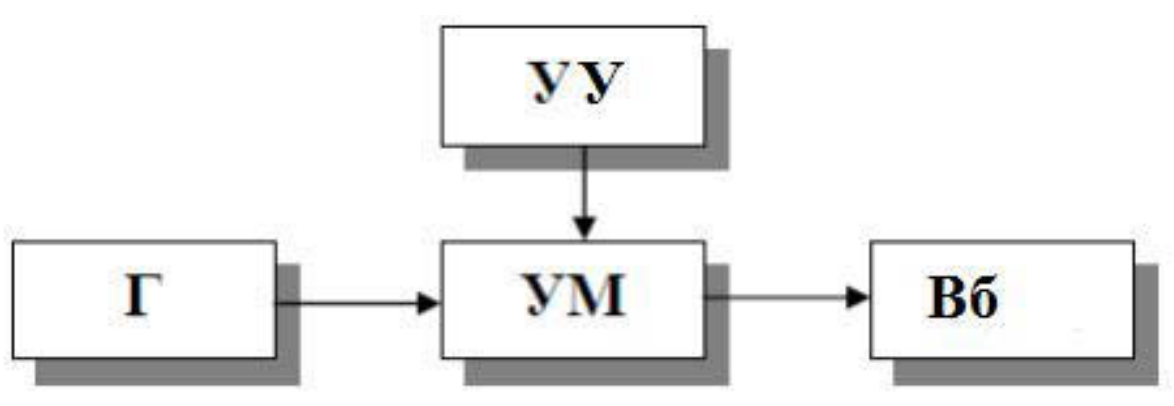

Рuс. 3. Структурная схема системы

Виброакустического зашумления.

Программные закладки класс программ с потенциально опасными последствиями, обязательно выполняющие следующие функции:

- разрушают код программы в памяти;

- сохраняют фрагменты информации из оперативной памяти в некоторой области внешней памяти прямого доступа;

- искажает произвольным образом, блокирует или подменяет выводимые во внешнюю память или в канал связи массив информации, образовавшийся в результате работы прикладных программ.

Программная реализация несанкционированного доступа к информации на основе использование программных закладок. Под несанкционированным доступом (НСД) к ресурсам компьютерной системы понимаются по использованию, изменению и уничтожению используемых данных указанной системы, производимые субъектом, не имеющие права на такие действия. Если компьютерная система содержит механизмы защиты от несанкционированного доступа, то несанкционированные действия могут быть вызваны:

- отключением или видоизменением защитных механизмов нелегальным пользователям;

- входом в систему под именем и с полномочиями реального пользователя.

В первом случае злоумышленник должен видоизменить программу, защитные механизмы в системе (например, отключить программу запросов пользователей), во втором - каким-либо образом выяснить или подделать идентификатор реального пользователя (например, подсмотреть или вычислить пароль, вводимый с клавиатуры).

В обоих случаях несанкционированный доступ можно представить моделью опосредованного доступа, когда проникновение в систему осуществляется на основе некоторого воздействия, произведенного предварительно внедренной в систему программой или несколькими программами. 
Особый интерес представляют уязвимые места компьютерных систем, используемые для внедрения программных закладок.

Внедрение возможно на всех участках жизненного цикла программного обеспечения:

- эскизного и технического проектирования;

- рабочего проектирования;

- внедрения;

- эксплуатации, включая сопровождение и модернизацию.

Несанкционированный доступ к ресурсам компьютерной системы Несанкционированный доступ к ресурсам компьютерной системы - действия по использованию, изменению и уничтожению используемых модулей и массивов данных, производимые субъектом, не имеющим права на такие действия

Несанкционированное вмешательство в процесс обмена сообщениями между узлами связи локально вычислительных сетей. Осуществляется путем передачи следующих сообщений:

- разрушающих;

- искажающих;

- имитирующих;

- хаотических.

Под уязвимостью компьютерной системы понимается некоторая слабость системы безопасности, которая может послужить причиной нанесения компьютерной системе ущерба. Обычно слабые (уязвимые) места в компьютерной системе называются дырами, люками, брешами.

Люк механизм внутри операционной системы (программное обеспечение), позволяющий программе злоумышленника получить привилегированную функцию. Умышленный люк может присутствовать в программе из-за того, что программист умышленно оставил его в программе, например:

- для обеспечения тестирования или выполнения оставшейся части отладки;

- в интересах облегчения окончательной сборки конечного программного продукта;

- с тем, чтобы иметь скрытое средство доступа к программе уже после того, как она вошла в состав конечного продукта.

В найденной бреши программа «разрывается, и туда дополнительно вставляют одну или несколько команд. Этот люк «открывается» по мере необходимости, а встроенные команды автоматически осуществляют свою задачу. Люк это возможность получить управление системой в обход защиты.

Изо всех известных угроз наиболее часто встречаются программные закладки типа «троянского коня» и «компьютерного червя».

«Троянский конь» программа, имеющая законный доступ к системе. Но выполняющая и скрытые функции. Закладки типа «троянский конь» проявляют себя в различных в определенных условиях (по времени, ключевым сообщениям) и могут разрушать (искажать) информацию, копировать фрагменты конфиденциальной информации или пароли (ключи), засылать сообщения не по адресу или блокировать прием (отправку) сообщений. 
В последние годы наиболее распространенным способом получения приватной информации стало использование программ - троянов - программ, выполняющих помимо заявленных некоторые дополнительные не афишируемых функции, направленные, например, на получение личной информации пользователя. Конечный пользователь получает их, как правило, по системе электронной почты под видом важного документа или давно разыскиваемой программы. После запуска программа прописывается в системном реестре для запуска при загрузке операционной системы и начинает собирать информацию. Ее целью могут быть файлы учетной записи пользователя, содержащие его пароль, скрипты удаленного доступа к Интернет или пароли электронной почты.

Возможна также ее работа в режиме подслушивания - в этом случае, например, все вводимые с клавиатуры символы записываются в отдельный файл, кроме того, «прослушиваться» может и передаваемая по сети информация. Далее вся собранная информация отправляется атакующему для дальнейшего анализа на предмет содержания ценной информации, такой как пароли или личная пользовательская информация.

Возможен также и самый простой способ: при работе пользователя на компьютере программа выводит на экран системное окно с предложением ввести имя пользователя и пароль, маскируясь под работу операционной системы. В результате пользователь «добровольно» сообщает злоумышленнику свой пароль, даже не подозревая о происшедшем. А если этим пользователем окажется ответственный сотрудник, то перед атакующим откроются огромные возможности.

«Программный червь» программа, маскирующаяся под системные средства поиска свободных вычислительных ресурсов в сети. Закладки типа компьютерного червя нацелены на проникновение в системы разграниченного доступа пользователей к ресурсам сети, к наущению работы всей сети в целом и системы разграничения доступа в частности.

Для того чтобы закладка смогла выполнить какие-либо функции по отношению к прикладной программе, она должна, получить управление на себя, т.е. процессор должен начать выполнять инструкции (команды), относящиеся к коду закладки. Это возможно только при одновременном выполнении двух условий:

- закладка должна находиться в оперативной памяти до начала работы программы, которая является целью воздействия закладки; следовательно, она должна быть загружена раньше или одновременно с этой программой;

- закладка должна активизироваться по некоторому общему как для закладки, так и доя программы событию, т.е. при выполнении ряда условий в программно-аппаратной среде управление должно быть, передано на программу - закладку.

К способам задействования программных закладок можно отнести:

1. запуск программы;

2. прерывания;

3. определенное сочетание входных данных;

4. определенное сочетание условий применения системы. 
По времени пребывания программной закладки в оперативной памяти можно выделить следующие типы закладок:

- резидентного вида - находятся постоянно с некоторого момента до окончания сеанса работы персонального компьютера (включения питание или перезагрузке). Закладка может быть загружена в память при начальной загрузке ПЭВМ, загрузке операционной среды или запуске некоторой программы (которая по традиции называется вирусоносителем), а также запущена отдельно;

- нерезидентного вида - начинают работу по аналогичному событию, но заканчивают ее самостоятельно по истечении некоторого промежутка времени или некоторому событию, при этом выгружая себя из памяти целиком.

Помимо классификации программных закладок по времени пребывания в оперативной памяти их можно классифицировать еще по методу их внедрения и по типам вредоносного воздействия. Представленная на рисунке 2 классификация выполнена достаточно наглядно и дополнительного пояснения не требует.

Таким образом, программные закладки в настоящее время являются наиболее мощным и эффективным инструментом в реализации компьютерных угроз, защита от которых должна быть динамичной и постоянно совершенствования. Одним из наиболее эффективных способов борьбы с сетевыми угрозами, в том числе с программными закладками, является совершенствования методов и средств контроля доступа к сети.

Заключение

Обеспечение сохранности информации - одна из основных и наиболее сложных задач, которые необходимо решать каждому предприятию. Сегодня организация работы любого предприятия, будь оно частным или государственным, претендующего на успешное развитие, обязательно базируется на современных информационных технологиях. Поэтому необходимо обращать внимание на стандарты управления информационной безопасностью. Как правило, вопросы управления информационной безопасностью тем актуальнее, чем крупнее организация, чем шире масштаб ее деятельности и претензии на развитие, и, как следствие, выше ее зависимость от информационных технологий.

Деятельность по защите информационных ресурсов от утечки информации должна быть строго спланирована и состоять из нескольких этапов:

1 этап - постановка задачи. Составление списка сведений, которые несут наиболее важную информацию.

2 этап - оценка ущерба, если сведения из перечня будут известны конкуренту; определение времени, необходимого конкуренту для реализации добытой информации.

3 этап - определение источников и каналов утечки информации.

4 этап - определение возможностей предотвращения утечки информации.

5 этап - определение стоимости мероприятий по защите информации. 


\section{Список литературы:}

1. Хорев А.А. Защита информации от утечки по техническим каналам. М.: НПЦ «Аналитика», 2008.

C. $436-440$.

2. Сидорин Ю.С. Технические средства защиты информации. СПБ.: СПбГПУ, 2005. С. 4-6, 8-10, 12-15.

3. Андрианов В.И., Бородин В.А., Соколов А.В. Шпионские штучки и устройства для защиты объектов и информации. Справочное пособие. СПБ.: Лань, 1997. С. 198-205.

4. Рыжиков Ю.И., Лохвицкий В.А. Расчет узла сети с отрицательными заявками // Информационные технологии в управлении (ИТУ-2012). 2012. С. 354-359.

5. Нечай А.А. Выявление недекларированных возможностей аппаратно-программного обеспечения // Экономика и социум. 2014. № 1-2(10). С. 457-460.

6. Лохвицкий В.А., Калиниченко С.В., Нечай А.А. Подход к построению системы автоматизированной интеграции информации в базу данных для её своевременной актуализации // Мир современной науки. 2014. № 2 (24). C. 8-12.

\section{References:}

1. Horev A.A. Protection of information from leakage through technical channels. M: research Analyst, 2008.

P. 436-440.

2. Sidorin Y.C. Technical means of information protection. SPB.: SPbSPU, 2005. P. 4-6, 8-10, 12-15.

3. Andrianov C.I., Borodin C.A., Sokolov A.C. Spy stuff and device for protection of objects and information. Reference manual, SPB.: DOE, 1997. P. 198-205.

4. Ryzhikov Y.I., lokhvitski C.A. Calculation of node networks with negative customers // Information technologies in management (ITU-2012). 2012. P. 354-359.

5. Nechay A.A. Detection of undeclared capabilities of the hardware-software // Economy and society. 2014. № 1-2(10). P. 457-460.

6. Lokhvitski C.A., Kalinichenko S.C., Nechay A.A. Approach to building a system for automated integration of data into a database for its timely update // Modern science. Publishing House. 2014. №2(24). P. 8-12.

(C) 2014, Нечай А.А., Проточанская Ю.Ю., Котиков П.Е.

Анализ каналов утечки информации
(C) 2014, Nechay A.A., Protochanska Yu.Yu., Kotikov P.E.

Analysis of the channels of leakage of information 
DOI: $10.17117 /$ no.2014.01.033

Поступило в редакцию: 03.11.2014

vka@mil.ru

\title{
Нечай А.А., Минухина Л.С., Котиков П.Е. Финансовые риски при утечке информации
}

\author{
Nechay A.A., Minuhina L.S., Kotikov P.E. \\ Financial risks of information leakage
}

Статья посвящена актуальному экономическому вопросу финансовых рисков при потере

информации. Сегодня информация играет большую роль в жизни любой компании или государственной организации, чем пару десятков лет назад. Ценным является также рассмотрение возможных рисков, угроз и их классификации, а также

технологических путей несанкционированного доступа

Ключевые слова: финансовые риск, утечка информации, угрозы информации, классификация угроз, несанкционированный доступ, утечка конфиденциальной информации

\section{Нечай Александр Анатольевич}

Преподаватель

Военно-космическая академия им. А.Ф. Можайского г. Санкт-Петербург, ул. Ждановская, 13

\section{Минухина Лариса Сергеевна}

Курсант

Военно-космическая академия им. А.Ф. Можайского 2. Санкт-Петербург, ул. Ждановская, 13

\section{Котиков Павел Евгеньевич}

Кандидат технических наук, доцент

Военно-космическая академия им. А.Ф. Можайского

2. Санкт-Петербург, ул. Ждановская, 13
The article is devoted to the economic, financial and o risks of information loss. Today, information plays a much greater role in the life of any company or government organization than a couple of decades ago. Valuable is also the consideration of possible risks, threats and their classification, as well as technological ways unauthorized access

Key words: financial risk, leakage of information, threat information, classification of threats, unauthorized access, leakage of confidential information

\section{Nechay Alexander Anatolievich}

Teacher

Military space Academy Alexander Mozhaisky

St. Petersburg, Zhdanov st., 13

\section{Minuhina Larisa Sergievna \\ Cadet}

Military space Academy Alexander Mozhaisky

St. Petersburg, Zhdanov st., 13

\section{Kotikov Pavel Evgenievich}

Candidate of Technical Sciences, associate Professor Military space Academy Alexander Mozhaisky

St. Petersburg, Zhdanov st., 13

Сегодня информация играет большую роль в жизни любой компании или государственной организации, чем пару десятков лет назад. Кто владеет информацией, тот владеет миром, а кто владеет чужой информацией, тот гораздо лучше подготовлен к конкурентной борьбе, чем его соперники.

Чем чреваты сегодня утечки конфиденциальной информации для тех, кто их допускает?

Внедрение новых информационных технологий ставит современные компании в зависимость от информационной системы, а переход на электронные носители информации приводит к необходимости уделять пристальное 
внимание вопросу информационной безопасности. Любое вмешательство в работу информационной системы: кража, уничтожение или несанкционированный доступ к данным может привести к значительным убыткам компании, а иногда и к ее полной ликвидации, особенно если эти данные касаются ее коммерческих тайн или ноу-хау.

Обеспокоенность внутренними угрозами информационной безопасности обоснована. Госструктуры и представители бизнес-сектора ставят на первое место утечку информации далеко не случайно, так как негативные последствия этого инцидента очевидны: прямые финансовые убытки, удар по репутации, потеря клиентов. Сравнение индексов обеспокоенности внутренними и внешними угрозами ИБ показывает, что именно инсайдерские риски превалируют в списке наиболее опасных угроз. Более того, наибольший рейтинг опасности приходится на утечку конфиденциальной информации.

Согласно данным портала информационной безопасности Content Security степень опасности внутренних и внешних угроз такова:

- разглашение (излишняя болтливость сотрудников) - 32\%;

- несанкционированный доступ путем подкупа и склонения к сотрудничеству со стороны конкурентов и преступных группировок - 24\%;

- отсутствие в фирме надлежащего контроля и жестких условий обеспечения информационной безопасности - $14 \%$;

- традиционный обмен производственным опытом - 12\%;

- бесконтрольное использование информационных систем - 10\%;

- наличие предпосылок возникновения среди сотрудников конфликтных ситуаций, связанных с отсутствием высокой трудовой дисциплины, психологической несовместимостью, случайным подбором кадров, слабой работой кадров по сплочению коллектива - 8\%.

Наиболее актуальными и значимыми, как это ни печально, оказываются угрозы, источником которых выступают пользователи системы и ее обслуживающий персонал, то есть сотрудники компаний. Такая тенденция подтверждается не только различными исследованиями крупнейших аудиторских компаний, но и отмечается в ежегодных докладах МВД России, посвященных правонарушениям в сфере информационной безопасности

Нельзя сказать, что проблема утечек информации появилась совсем недавно - такие вещи, как промышленный шпионаж, переманивание ценных специалистов вместе с их наработками и знаниями и другие подобные действия известны уже достаточно давно.

Каким образом можно оценить возможный ущерб от утечки конфиденциальных данных?

Для начала необходимо свериться со списком возможных источников ущерба:

- Упущенная выгода в результате испорченного имиджа;

- Штрафы со стороны регуляторов;

- Компенсации по судебным искам;

- Снижение котировок акций (для акционерных компаний) в результате попадания на рынок инсайдерской информации; 
- Прямые убытки: стоимость разработки технологических решений, стоимость проигранных в результате утечек данных тендеров и т.д.

Каждая утечка информации «ставит галочку» напротив как минимум одного из перечисленных выше пунктов, наиболее серьезные же утечки способны «преподнести» компании весь этот список. Соответственно, общая сумма ущерба от каждой конкретной утечки информации складывается из «цены» каждого источника ущерба.

Конечно, не для всех перечисленных пунктов подсчитать возможную стоимость ущерба достаточно просто.

Если, к примеру, штрафы со стороны регуляторов или стоимость технологических разработок подсчитать не так уж сложно, то предсказать, как поведет себя рынок ценных бумаг в ответ на обнародованные инсайдерами документы, или сколько клиентов отвернутся от компании в результате ухудшившейся репутации, практически невозможно. Поэтому в своих оценках лучше не придерживаться оптимистической позиции «все обойдется», а закладывать в «бюджет» утечки максимально возможную сумму ущерба.

К сожалению, достоверных исследований, которые показывали бы среднюю стоимость утечки информации в России, пока нет, однако можно ориентироваться на данные для других стран, которые вряд ли будут существенно отличаться

Так, согласно исследованиям Ponemon Institute, средняя стоимость утечки информации для фирм в Великобритании в 2008 г. составила 1,7 млн. фунтов, то есть почти 80 миллионов российских рублей.

Еще одна цифра: в среднем убытки при потере служебного ноутбука составляют почти 50 тыс. долларов - такие данные были получены после опроса представителей 29 организаций, которые пережили 138 отдельных случаев потери ноубтуков их постоянными или временными сотрудниками, пишет Руформатор со ссылкой на PCWorld. Такая сумма получена с помощью учета семи различных факторов: цены самого ноутбука, определения потерянных данных, экспертизы и расследования обстоятельств потери, сообщения об утечке данных и действий по смягчению последствий инцидента, потери интеллектуальной собственности, потери производительности, а также других юридических и нормативных затрат.

Эксперты также подсчитали, что чем быстрее компания реагирует на утрату компьютера, тем меньшие потери она несет.

Если потерю ноутбука удалось обнаружить в тот же день, то затраты могут составить в среднем лишь 8950 долларов. Спустя неделю они могут достичь уже 115849 долларов.

Шифрование данных приводит к существенному снижению финансовых потерь при утрате компьютера.

Так, если информация на жестком диске ноутбука была зашифрована, потеря обходится в 37443 долларов, если нет, - то в 56165 долларов.

Наконец, финансовые потери напрямую зависят от того, какую должность в компании занимает человек, потерявший компьютер или лишившийся его в результате кражи. 
Наибольшей ценностью обладает ноутбук не высшего должностного лица компании, а директора или менеджера. Потеря ноутбука топ-менеджером обходится в среднем в 28449 долларов, но если его потеряли директор или менеджер, сумма возрастает до 60781 долларов и 61040 долларов соответственно. Это свидетельствует о высоком уровне риска для корпоративных сетей, потому что доступ к сайтам для взрослых, поиск работы на подозрительных ресурсах и другие виды нецелевого использования рабочих ноутбуков могут привести к серьезным утечкам информации, а иногда и к проникновению вредоносного ПО в сеть организации.

Для чего оценивать возможный ущерб от утечек информации?

Прежде всего, для того, чтобы понять, какую цену в действительности имеет конфиденциальная информация, которой обладает организация, а также оценить выгоду от внедрения средств защиты от утечек информации (например, DLP-систем - от английского Data Leak Prevention, предотвращение утечек данных). Выгода, конечно же, есть, когда стоимость возможных утечек хотя бы в 2 раза превышает стоимость внедрения подобной системы. Как показывает практика, для подавляющего большинства компаний внедрение DLPсистемы действительно целесообразно.

Защита от внутренних угроз.

Ни для кого не секрет, что в среднем 82 \% угроз информационным ресурсам компаний исходят от действий собственных сотрудников, совершаемых ими либо по неосторожности, либо предумышленно. По прогнозам экспертов, опасность внутренних угроз имеет тенденцию к росту и является по-прежнему одной из самых злободневных проблем. В условиях жесткой конкурентной обстановки особенно актуальной является задача по сохранению конфиденциальности данных.

Ошибочно отправленное электронное письмо, сообщение ICQ или выводимые на печать документы могут содержать конфиденциальные сведения, не предназначенные для посторонних лиц. Коммерческая или служебная тайна, персональные данные клиентов, партнеров или сотрудников, а также иные виды защищаемой информации могут попасть в руки к третьим лицам и нанести бизнесу непоправимый ущерб. Необходимо своевременно принять меры для предотвращения рисков, связанных с утечкой конфиденциальной информации.

Возможные риски:

- Финансовые риски - результатом утечки конфиденциальных данных может быть ситуация, когда коммерческая тайна становится известной третьим лицам. В случае попадания такой информации в руки конкурентов существует высокая вероятность финансовых потерь, нередко приводящих к банкротству компании.

- Правовые риски - бесконтрольный выход конфиденциального документа за пределы корпоративной сети может стать предметом пристального внимания со стороны регулирующих органов. Судебные иски и штрафные санкции за нарушение норм законодательства, регулирующих защиту персо- 
нальных данных и иных видов конфиденциальной информации, не является редким явлением.

- Репутационные риски - утечка конфиденциальных данных может получить широкую огласку в СМИ и привести к разрушению имиджа компании в глазах ее клиентов и партнеров, став причиной серьезного финансового ущерба.

Для обеспечения защиты от утечек информации должна быть предусмотрена DLP-система.

DLP-системы (от англ. Data Loss Prevention) - программные или программно-аппаратные средства, предназначенные для защиты от утечек по сетевым и локальным каналам. Передаваемые данные анализируются на предмет их конфиденциальности и распределяются по определенным категориям (общедоступная информация, персональные данные, коммерческая тайна, интеллектуальная собственность и др.). Если в информационном потоке детектируются данные конфиденциального характера, DLP-система выполняет одно из следующих действий: разрешает их передачу, блокирует или отправляет на дополнительную проверку специалисту по безопасности в неоднозначных случаях.

DLP-системы охватывают широкий комплекс коммуникационных каналов, позволяя отслеживать электронную почту, службы мгновенных сообщений и иной интернет-трафик, принтеры, Bluetooth-устройства, USB-устройства и другие внешние носители.

Существующие DLP-системы различаются набором функциональных возможностей.

Bo-первых, DLP-системы могут быть активными (обнаруживают и блокируют утечку данных) и пассивными (обнаруживают утечку данных и высылают оповещение об инциденте). В настоящее время акцентируется внимание на активных DLP-системах, основная задача которых - предотвращение утечки данных в режиме реального времени, а не выявление ее постфактум. Для таких DLP-систем можно при желании настроить режим мониторинга, позволяющий не вмешиваться в бизнес-процессы и направлять сообщение об инциденте специалисту по безопасности.

Bo-вторых, DLP-системы могут решать ряд дополнительных задач, связанных с контролем действий сотрудников, их рабочего времени и использования корпоративных ресурсов.

Весомый плюс DLP-систем заключается в том, что они позволяют сохранять непрерывность бизнес-процессов, практически не влияя на работу конечных пользователей. Благодаря всем вышеперечисленным возможностям DLP-системы в настоящий момент - одно из самых востребованных решений для обеспечения информационной безопасности бизнеса.

Правильное внедрение и настройка DLP-системы - отдельный сложный вопрос. Здесь невозможно обойтись без грамотного консалтинга. Высококвалифицированные специалисты компании «Инфозащита» помогут с выбором решения, соответствующего специфике Вашего предприятия. 
Современный рынок DLP - один из самых быстрорастущих, что ярко демонстрирует высокий спрос на подобные системы защиты. Разработчики DLPрешений постоянно развивают и совершенствуют новые эффективные технологии для борьбы с утечками данных.

Угрозы информационной безопасности. Классификация угроз

Построение надежной защиты информационной системе организации невозможно без предварительного анализа возможных угроз безопасности системы.

Под угрозой безопасности информации понимаются события или действия, которые могут привести к искажению, несанкционированному использованию или даже к разрушению информационных ресурсов управляемой системы, а также программных и аппаратных средств.

Угрозами информационной безопасности называются потенциальные источники нежелательных событий, которые могут нанести ущерб ресурсам информационной системы.

Все угрозы безопасности, направленные против программных и технических средств информационной системы, в конечном итоге оказывают влияние на безопасность информационных ресурсов и приводят к нарушению основных свойств хранимой и обрабатываемой информации.

Угрозы информационной безопасности различают по следующим основным признакам:

По характеру возмущающих воздействий на систему угрозы разделяются на случайные или непреднамеренные и умышленные.

Источником непреднамеренных угроз могут быть выход из строя аппаратных средств, неправильные действия работников информационной системы или ее пользователей, непреднамеренные ошибки в программном обеспечении и т.д. Такие угрозы следует держать во внимании, так как ущерб от них может быть значительным.

Умышленные угрозы в отличие от случайных преследуют цель нанесения ущерба управляемой системе или пользователям. Это делается нередко ради получения личной выгоды. Человека, пытающегося нарушить работу информационной системы или получить несанкционированный доступ к информации, обычно называют взломщиком, а иногда «компьютерным пиратом» (хакером).

По характеру нанесенного ущерба умышленные угрозы подразделяют на пассивные и активные.

Пассивные угрозы направлены в основном на несанкционированное использование информационных ресурсов ИС, не оказывая при этом влияния на ее функционирование. Например, несанкционированный доступ к базам данных, прослушивание каналов связи и т.д.

Утечка конфиденциальной информации - это бесконтрольный выход конфиденциальной информации за пределы ИС или круга лиц, которым она была доверена по службе или стала известна в процессе работы. Эта утечка может быть следствием:

- разглашения конфиденциальной информации; 
- ухода информации по различным, главным образом техническим, каналам;

- несанкционированного доступа к конфиденциальной информации различными способами.

Разглашение информации ее владельцем или обладателем есть умышленные или неосторожные действия должностных лиц и пользователей, которым соответствующие сведения в установленном порядке были доверены по службе или по работе, приведшие к ознакомлению с ним лиц, не допущенных к этим сведениям.

Возможен бесконтрольный уход конфиденциальной информации по визуально-оптическим, акустическим, электромагнитным и другим каналам.

Несанкционированный доступ - это противоправное преднамеренное овладение конфиденциальной информацией лицом, не имеющим права доступа к охраняемым сведениям.

Наиболее распространенными путями несанкционированного доступа к информации являются:

- перехват электронных излучений;

- принудительное электромагнитное облучение (подсветка) линий связи с целью получения паразитной модуляции несущей;

- применение подслушивающих устройств (закладок);

- дистанционное фотографирование;

- перехват акустических излучений и восстановление текста принтера;

- чтение остаточной информации в памяти системы после выполнения санкционированных запросов;

- копирование носителей информации с преодолением мер защиты;

- маскировка под зарегистрированного пользователя;

- маскировка под запросы системы;

- использование программных ловушек;

- использование недостатков языков программирования и операционных систем;

- незаконное подключение к аппаратуре и линиям связи специально разработанных аппаратных средств, обеспечивающих доступ к информации;

- злоумышленный вывод из строя механизмов защиты;

- расшифровка специальными программами зашифрованной информации;

- информационные инфекции.

Перечисленные пути несанкционированного доступа требуют достаточно больших технических знаний и соответствующих аппаратных или программных разработок со стороны взломщика. Например, используются технические каналы утечки - это физические пути от источника конфиденциальной информации к злоумышленнику, посредством которых возможно получение охраняемых сведений.

Однако есть и достаточно примитивные пути несанкционированного доступа:

- хищение носителей информации и документальных отходов; 
- инициативное сотрудничество;

- склонение к сотрудничеству со стороны взломщика;

- выпытывание;

- подслушивание;

- наблюдение и другие пути.

Любые способы утечки конфиденциальной информации могут привести к значительному материальному и моральному ущербу как для организации, где функционирует ИС, так и для ее пользователей.

Довольно большая часть причин и условий, создающих предпосылки и возможность неправомерного овладения конфиденциальной информацией, возникает из-за элементарных недоработок руководителей организаций и их сотрудников.

Например, к причинам и условиям, создающим предпосылки для утечки коммерческих секретов, могут относиться:

- недостаточное знание работниками организации правил защиты конфиденциальной информации и непонимание необходимости их тщательного соблюдения;

- использование неаттестованных технических средств обработки конфиденциальной информации;

- слабый контроль за соблюдением правил защиты информации правовыми, организационными и инженерно-техническими мерами;

- текучесть кадров, в том числе владеющих сведениями, составляющими коммерческую тайну;

- организационные недоработки, в результате которых виновниками утечки информации являются сотрудники.

Большинство из перечисленных технических путей несанкционированного доступа поддаются надежной блокировке при правильно разработанной и реализуемой на практике системе обеспечения безопасности. Но борьба с информационными инфекциями представляет значительные трудности, так как существует и постоянно разрабатывается огромное множество вредоносных программ, цель которых - порча информации в базах данных и программном обеспечении компьютеров. Большое число разновидностей этих программ не позволяет разработать постоянных и надежных средств защиты против них.

\section{Список литературы:}

1. Николаева Т.П. Основы информационной экономики. СПБ.: ЛЕКС СТАР, 2001. С. 128.

2. Федеральный закон «Об информации, информатизации и защите информации» от 25 января 1995 года № 24-Ф3.

3. Федеральный закон Российской Федерации "О государственной тайне" от 21 июля 1993 года N 5485-1.

4. Федеральный закон Российской Федерации «О коммерческой тайне» от 29 июля 2004 г. N 98-ФЗ.

5. Ильин А.И., Волков В.П. Экономика предприятия. М.: Новое знание, 2003. С. 677.

6. Нечай А.А. Выявление недекларированных возможностей аппаратно-программного обеспечения // Экономика и социум. 2014. № 1-2 (10). С. 457-460.

7. Лохвицкий В.А., Калиниченко С.В., Нечай А.А. Подход к построению системы автоматизированной интеграции информации в базу данных для её своевременной актуализации // Мир современной науки. 2014. № 2 (24). C. 8-12. 


\section{References:}

1. Nikolaeva T.P. Basis of the information economy. SPB.: LEX STAR, 2001. P. 128.

2. Federal law "On information, Informatization and protection of information" dated January 25, 1995 № 24-FZ.

3. Federal law of the Russian Federation "On state secrets" dated July 21, 1993 N 5485-1.

4. Federal law of the Russian Federation "On commercial secrets" dated 29 July 2004, № 98-FZ.

5. Ilyin A.I., Volkov V.P. Business Economics. M.: New knowledge, 2003. P. 677.

6. Nechay A.A. Detection of undeclared capabilities of the device-but-software // Economy and society. 2014. № 1-2 (10). Pp. 457-460.

7.Lokhvitski C.A., Kalinichenko S.C., Nechay A.A. Approach to building a system for automated integration of data into a database for its timely update // the World of modern science. 2014. № 2 (24). Pp. 8-12.

(C) 2014, Нечай А.А., Минухина Л.С., Котиков П.Е. Финансовые риски при утечке информации
(C) 2014, Nechay A.A., Minuhina L.S., Kotikov P.E. Financial risks of information leakage 


\title{
Ажгихин С.Г., Селезнева Т.В. Специфика проектирования жилого помещения с учетом потребностей и интересов жильцов
}

\author{
Azhgikhin S.G., Selezneva T.V. \\ Specific features of the premises design which \\ meets the needs and interests of tenants
}

В статье затронута проблема проектирования жилого помещения с учетом потребностей и интересов жильцов. Предлагается осуществление проектирования жилого помещения, учитывая индивидуальные особенности жильцов, их интересы. Этапы и особенности дизайнпроектирования жилых помещений показаны на примере частного дома в станище Динской. Представленные в статье особенности дизайнпроектирования жилых помещений находят применение в учебном процессе вузов в ходе профессиональной подготовки будущих дизайнеров Ключевые слова: дизайн интерьера, проектирование жилых помещений, специфика проектирования жилых помещений с учетом потребностей и интересов жильцов, дизайнерское решение

\section{Ажгихин Сергей Геннадьевич}

Кандидат педагогических наук, доцент, профессор Кубанский государственный университет

г. Краснодар, ул. Ставропольская, 149

\section{Селезнева Татьяна Васильевна}

Магистрант

Кубанский государственный университет

г. Краснодар, ул. Ставропольская, 149
The article deals with the problem of designing of residential premises to meet the needs and interests of tenants. It is proposed the designing of residential premises, taking into account the individual characteristics of the residents, their interests. Stages and features design designing living spaces shown on the example of a private house in the village Dinskoy. Presented in the article features of design designing of residential premises are used in the educational process of higher education institutions in the training of future designers

Key words: interior design, premises design, specific features of the premises design which meets the needs and interests of tenants, design solution

\section{Azhgikhin Sergey Gennadevich}

Candidate of Pedagogic Sciences, Professor, head of

Department

Kuban State University

Krasnodar Stavropolskaya St., 149

\section{Tatyana Vasilevna Selezneva}

Undergraduate

Kuban State University

Krasnodar Stavropolskaya St., 149

В наши дни понятие дизайн интерьера стало популярным. Каждый отдельный индивид мечтает создать в своем доме интерьер, который будет включать в себя набор не только эстетичных, но и практичных свойств. В этот момент появляется потребность в дизайнере. Ведь не всегда человек имеет четкое представление о том, что ему нужно для комфортной жизнедеятельности. Поэтому главной задачей дизайнера становится проектирование интерье- 
ра под конкретного человека. В этой статье будет рассмотрена специфика такого проектирования. Данное исследование поможет понять основные принципы проектирования, которые можно будет применять в педагогической деятельности, что позволит повысить качество проектирования у студентов вузов, обучающихся по направлению "Дизайн".

Очень важным аспектом в проектировании является создание комфорта в помещении, который в первую очередь должен ощущаться жильцами. Комфорт может быть психологическим, физиологическим, функциональным. При этом каждый вид комфорта может восприниматься личностью индивидуально. Все, что будет отклоняться от понимания комфорта в собственном жилье, безусловно, отразится на поведении и отношении человека к окружению.

Каждое жилое помещение должно проектироваться в соответствии с индивидуальными качествами людей, которые в нем проживают. Оно не должно противоречить устоявшемуся порядку жизни того или иного человека. И для того, чтобы создать такое пространство, для начала необходимо изучить и проанализировать потребности, желания и увлечения каждого отдельно взятого члена семьи.

Еще один фактор, который следует учитывать при проектировании жилого помещения, это то, что зачастую в доме может проживать не один человек, а целая семья. Проектирование должно обеспечивать понимание дома, как целостного пространства, частью которого являются и сами обитатели дома. Проект должен давать возможность каждому проживающему в доме человеку идентифицировать себя с пространством. Поэтому для достижения гармоничного единства интересов каждого человека и всей семьи необходимо предусмотреть обособленные пространства, как для индивидуальных потребностей, так и для общесемейных, с учетом некоторой изоляции одних от других.

Но при распределении пространств для индивидуальных и общесемейных потребностей следует избегать возможности жилищной скученности. Ведь пребывание в пространстве, где наблюдается большое скопление людей, зачастую вызывает у человека жалобы и недовольства, о чем свидетельствует множество примеров.

Несомненно, каждой личности необходимо свое физическое пространство, предназначенное для удовлетворения своих потребностей. В настоящее время человек перегружен тем, что он находится в окружении множества людей. Это и работа, и общественный транспорт, и учебные заведения. Естественно, приходя домой, ему необходимо оторваться от этого и элементарно отдохнуть. Эта позиция сегодня стала важнейшей не только в утилитарнофизическом, но и в психологическом отношении.

Кроме того, следует обращать внимание еще на один аспект создания комфортности жилого помещения. Он выражен в стремлении человека к контролю над пространством, в пространственной отгороженности, обособленности и других регуляторах уединенности, в необходимости создания своего порядка в расположении вещей. При этом задачей проектирования становится выявление ценностей и норм, ожидаемых, желаемых, живущих в культурном сознании индивида. Следовательно, и созданная предметно-пространственная 
среда должна обладать качеством точного соответствия человеческим потребностям. Все элементы этой среды должны быть подогнаны под конкретного человека.

Если все элементы пространства подобраны правильно и ничего не отвлекает человека от трудовой деятельности и социальных отношений, то начинается процесс совершенствования своей собственной природы.

При проектировании жилых помещений так же следует учитывать, что индивиды могут подвергаться положительным или отрицательным воздействиям в той мере, в какой используемые ими предметы жизнедеятельности соответствуют особенностям строения человеческого тела, сенсорной и двигательной системам их поведения. Любое жилое помещение накладывает ограничение на его обитателей. Продуманное до мелочей жилое пространство в зависимости от того, верно оно продуманно или нет, может облегчить или усложнить человеку выполнение жизненных функций.

До сих пор мало известно о том, что же такое феномен «обитания». Нет ни одного углубленного исследования самого «акта обитания», феномена чрезвычайно сложного, богатого, несводимого только к утилитарному использованию дома, но сообщающего функциональному действию культурную и символическую значимость.

Жилище создано для того, чтобы обеспечить человеку такие условия проживания, где множество связей с окружающей средой контролировались бы человеком без особого усилия, были подвластны ему. Так, в рисунке «Эгоцентрическое очертание пространства» человек изображен в центре создаваемой им (паутины) среды, он хозяин положения и управляет нитями-связями по своему желанию (рис. 1).

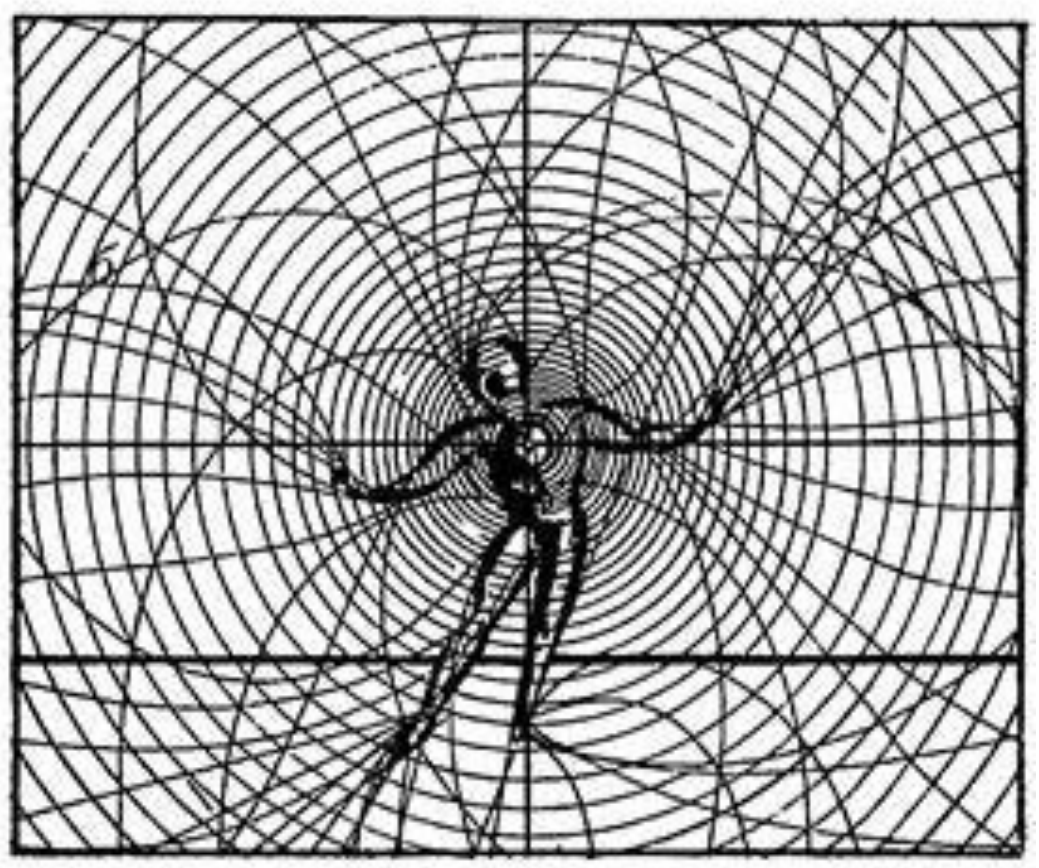

Рис. 1. Эгоцентрическое очертание пространства 
Глядя на рисунок, хотелось бы верить, что человек - центр мироздания, что многочисленные связи с окружающей средой, ближним и дальним Космосом контролируются им, подвластны ему. Он, как паучок в центре сплетенной им паутины, - хозяин положения и играет нитями по своему желанию. В действительности все наоборот. Сегодня человек все чаще оказывается не хозяином положения, а жертвой, попавшей в густую паутину неблагоприятных факторов естественного и техногенного происхождения.Проверено многолетним опытом, что в случаях, где при проектировании учет человеческих факторов не ведется или же сводится к минимуму, чаще происходят заболевания и несчастные случаи.

В последнее время ни один проект жилища не обходится без такого термина, как эргономическое проектирование. Это и понятно, ведь решение задачи создания жилого пространства, наиболее полно отвечающего современным требованиям повышения качества жизни, будет возможным только при масштабном использовании эргономики как научной основы проектирования. Эргономика так же является основой методологии средового проектирования, поскольку именно она оказывается соединительным звеном между базовыми понятиями «среда» (как конечный продукт проектного творчества) и «человек» (как его заказчик и потребитель).

Эргономика включает в себя свод правил, основанных на физических и психических особенностях человеческого организма. Она помогает проектировать комфортное жилое пространство.

Эргономика позволяет решить многие проблемы. Например, при определении соотношения между архитектурными структурами и моделями организации пространства, при нахождении размеров, форм и других общих свойств пространства, при организации маршрутов передвижения, отвечающих требованиям выполнения деятельности и ее эффективности, охраны труда и безопасности, при совмещении деятельности людей и окружающей среды. К ней так же прибегают, подбирая мебель, оборудование и их конструктивные характеристики, влияющие на выполнение того или иного вида деятельности. Расположение мебели, приспособлений и оборудования так же не обходятся без обращения к основам эргономики. Так же она рекомендует учитывать особенности групп людей и виды деятельности, требующие специальные типы мебели [1].

При помощи эргономики решается и проблема отделки внутренних поверхностей, оказывающих влияние на восприятие и деятельность человека. Влияние температуры, движения воздуха, влажности, звука, шума, освещения и климатических условий так же следует учитывать при проектировании [6].

Проектирование интерьера жилого помещения необходимо начинать с предпроектного анализа, который должен включать в себя изучение семьи заказчика, выявление потребностей и интересов.

Проектировщик не может считать, что владеет полной информацией о проектируемом объекте, пока не убедится, что получил представление о его особенностях в максимально полном объеме. После полученной информации начинается непосредственно сам процесс выявления существующих проблем. 
После чего идет поиск возможных путей их решения. Такое эргономическое проектирование по четко сформулированным целям, задачам и содержанию является человекоориентированным.

В ходе исследования были сформулированы основные принципы проектирования жилого пространства. Во-первых: необходимо было выявить психологическое значение происходящих функциональных процессов, безопасность и прогнозируемость работы человека. Во-вторых, человек должен полностью контролировать ситуацию в среде обитания и функционирование оборудования. В-третьих, жилище следует проектировать таким образом, чтобы предоставить жильцам выбор, как его использовать; должна быть заложена возможность оставаться свободными в формировании своих собственных методов работы. А для этого внутреннее пространство жилья необходимо организовать так, чтобы предоставить им такую возможность. Это подразумевает, что следует предусматривать не один, а несколько возможных способов выполнения определенной задачи [2].

Реализация рассмотренных принципов позволит решить основную задачу эргономического проектирования, направленную на создание комфортной среды обитания и оптимизацию деятельности человека в собственном жилье.

Задачи, решаемые в процессе работы над дизайн-проектом, должны досконально разбираться, уточняться, корректироваться и дополняться при последовательном переходе от одного этапа к другому. При этом проектирование и формирование среды должно происходить с ориентацией на эргономические критерии качества среды.

Покажем этапы и особенности дизайн-проектирования жилых помещений на примере частного дома в станице Динской (рис. 2).

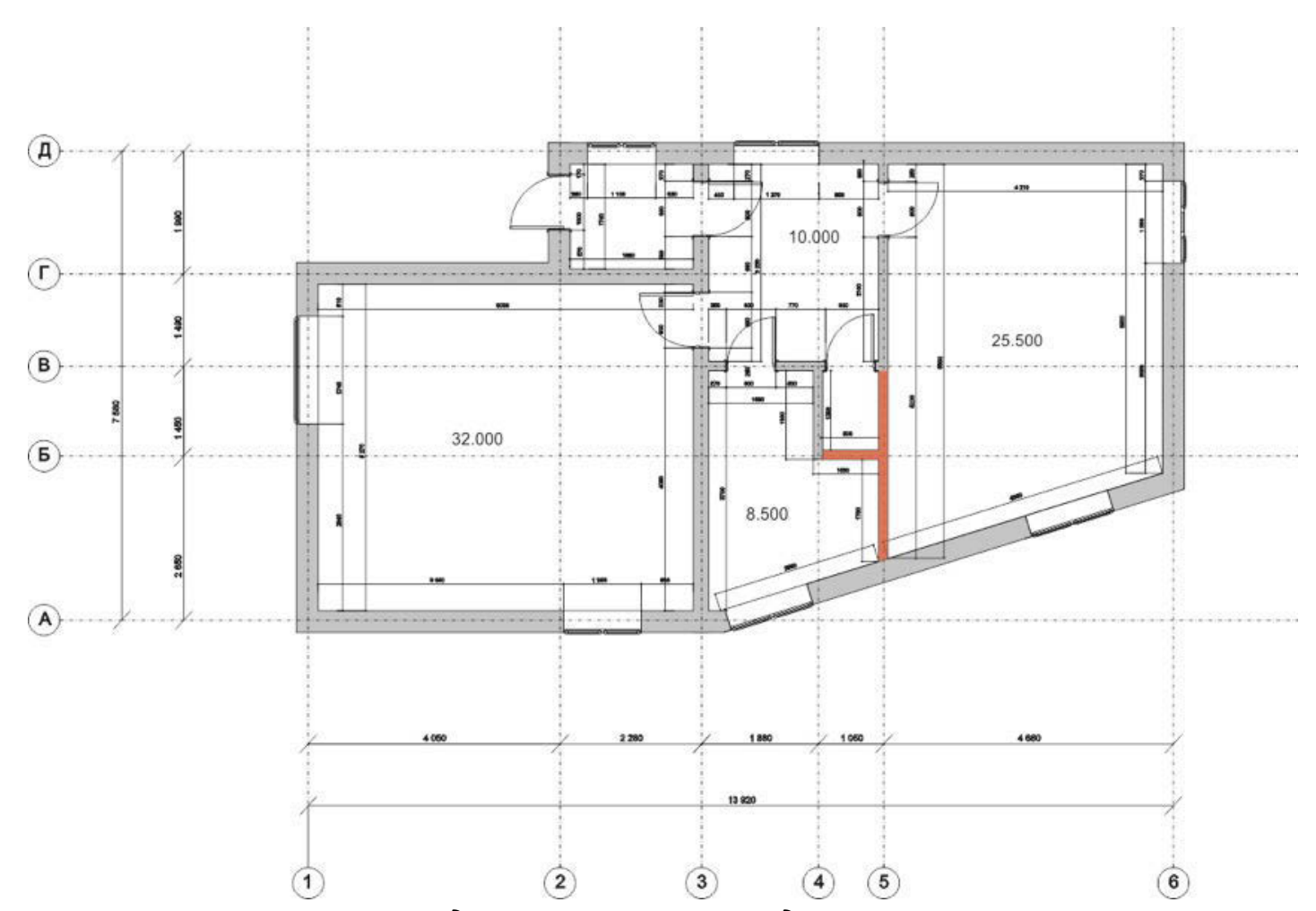

Рис. 2. План дома в $\mathrm{cm}$. Динская до реконструкции 
В процессе дизайн-проектирования следующие задачи:

- выявлены потребности и интересы семьи заказчика;

- проведен предпроектный анализ каждого помещения;

- разработана проектная концепция дизайна каждого помещения;

- создан дизайн-проект каждого жилого помещения с учетом эстетических и эргономические требований.

В результате проведенного анализа четко сформировалась концепция каждого помещения: интерьеры должны погрузить хозяев дома в атмосферу путешествий. Каждая комната будет являться образом того или иного региона планеты.

При проектировании интерьера кухни-гостиной были решены следующие задачи:

- проведено грамотное зонирование;

- обеспечено достаточное освещение;

- введена система вентиляции воздуха;

- учтено расположение отверстий под канализацию;

- созданы условия для комфортной работы на кухне;

- подобрана мебель для столовой;

- обеспечен подход к столу со всех сторон;

- спроектирована площадка для танцев;

- грамотно расставлена техника;

- спроектированы комфортные места для просмотра телевизора, чтения, шитья, работы с ноутбуком;

- учтены эргономические требования;

- создано освещение для каждой описанной ситуации.

При проектировании интерьера спальной комнаты были решены следующие задачи:

- обеспечена хорошая освещенность комнаты;

- создано помещение для отдыха;

- выбрано место для расположения телевизора;

- подобранна мебель, соответствующая эргономическим требованиям;

- проведено грамотное зонирование комнаты.

При проектировании интерьера ванной-гардеробной были решены следующие задачи:

- учтена необычная форма помещения;

- обеспечено достаточное освещение;

- учтены возможности проведения канализации;

- добавлены элементы интерьера, наиболее полно отвечающие нуждам хозяйки помещения (туалетный столик, зеркало и др.);

- грамотно найти место для гардеробной комнаты;

- подобраны места хранения предметов и вещей;

- продумано расположение входа в гардеробную и место для гладильной доски;

- использованы влагоустойчивые материалы;

- обеспечена хорошая вентиляция комнаты; 
- правильно размещена стиральная машинка;

- найдены места хранения порошков, шампуней, тазика, грязного белья и т.Д.;

- учтены пожелания заказчиков по поводу размещения ванной на подиумe;

- включены в проект теплые полы.

При проектировании интерьера прихожей и коридора были решены следующие задачи (рис. 3):

- визуально расширено пространство;

- подобранно освещение помещения;

- созданы места хранения обуви и верхней одежды;

- визуально расширено пространство;

- спроектированы места расположения гостей.

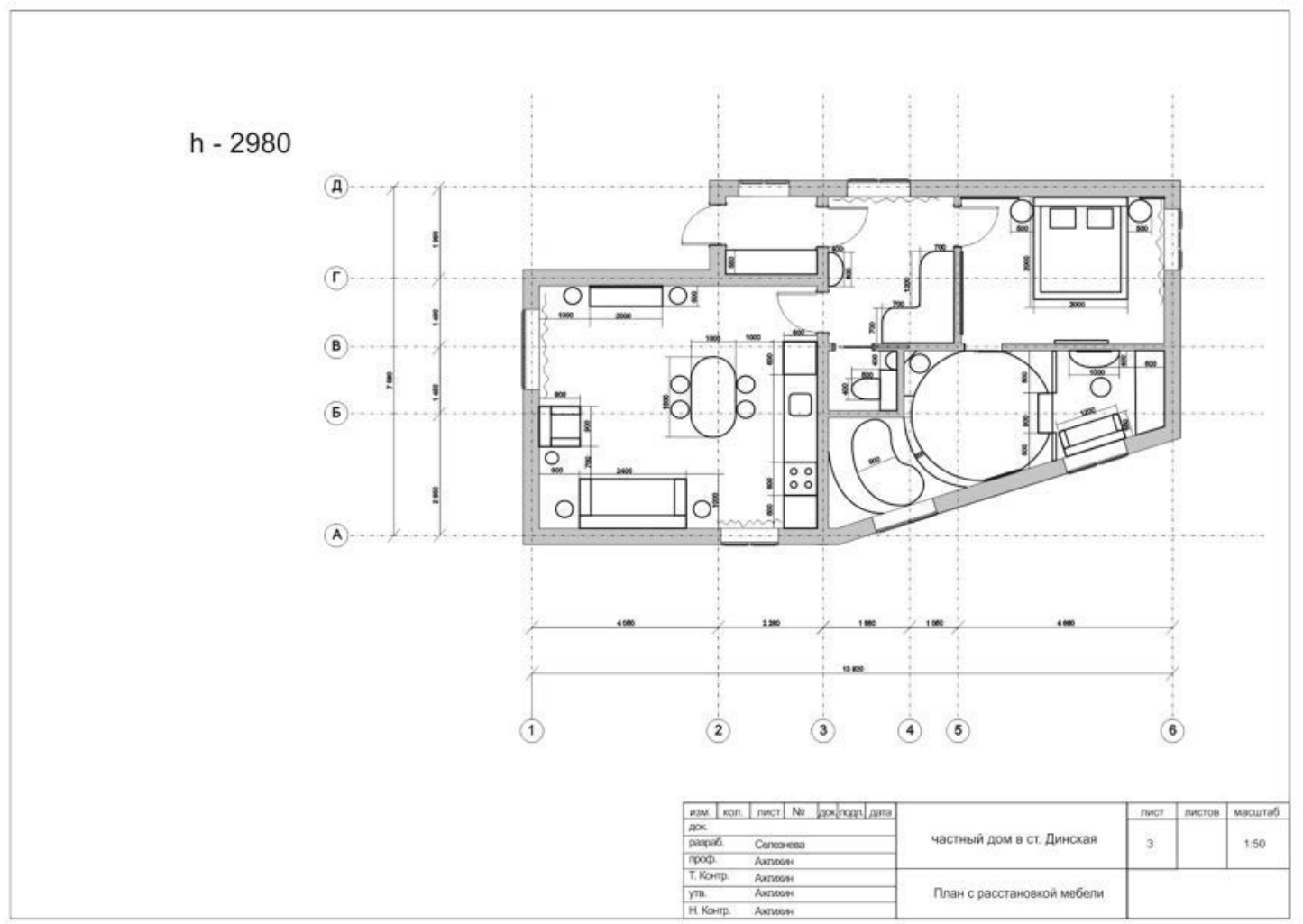

Рис. 3. План дома в ст. Динская. После реконструкции. Расстановка мебели

Таким образом, в результате проведенной работы было спроектировано функциональное жилое помещение, учитывающее потребности, интересы и увлечения жильцов.

На сегодняшний день процесс дизайн-проектирования оказывается все меньше направленным на сам проектируемый объект и все больше - на те преобразования, которые должен претерпевать интерьер жилого помещения в ходе его освоения обитателями. В связи с этим вряд ли стоит заявлять о какомто существенном изменении в эволюции жилища будущего. По всей вероятности, более верно будет говорить о нарастании многообразия типов жилой среды на основе всестороннего учета человеческого фактора [5]. 
Проектирование жилого пространства все более и более будет апеллировать к индивиду не как к объекту со стандартным набором известных параметров, а как к индивидуальности с огромным комплексом духовных потребностей. Поскольку на сегодняшний день индивидуализация жилища стала очевидна, необходимо огромное разнообразие композиционных решений, которое в достаточной мере могло бы содействовать «самовыражению» каждого отдельного индивида в интерьере своего дома. Но критерием оценки «художественности» должен быть не рыночный спрос, а изысканный вкус специалиста.

В развитии проектирования жилых пространств начинается качественно новый этап, ориентированный на удовлетворение сугубо индивидуальных потребностей человека.

\section{Список литературы:}

1. Алексеев П.Г. Основы эргономики в дизайне. СПб., 2010.

2. Ажгихин С.Г., Марченко М.Н. Типы принятия решений в процессе проектной деятельности //

21 century: fundamental science and technology. Vol.2. North Charleston, 2014. C. 86-89.

3. Марченко М.Н. Влияние дизайнерской деятельности на развитие способностей обучающихся $\kappa$ творчеств // Международный журнал экспериментального образования // 2013. № 11-13. С. 201-203. 4. Мунипов В.М., Зинченко В.П. Эргономика. М., 2001.

5. Ожиганов Е.А., Человекоориентированное проектирование жилища // Архитектон: известия вузов. 2005. Июль. № 10.

6. Рунге В.Ф. Эргономика и оборудование интерьера. М., 2004.

7. Устин В.Б. Художественное проектирование интерьеров. М., 2010.

8. Чавойски Р., Першивы И. Наш дом. Братислава, 1988.

\section{References:}

1. Alekseev, P.G. Fundamentals of ergonomics in the design: a teaching aid. SPb., 2010.

2. Azhgikhina S.G., Marchenko M.N. Types of decision-making in the project activities // 21 century:

fundamental science and technology. Vol. 2. North Charleston, 2014. Pp. 86-89.

3. Marchenko M.N. Influence of design activities for the development of abilities of students to be creative // International Journal of Experimental Education. 2013. № 11-13. Pp. 201-203.

4. Munipov V.M., Zinchenko V.P. Ergonomics. M., 2001.

5. Ozhiganov E.A., Chelovekoorientirovannoe design of the home // Architect: Proceedings of Higher Education. 2005. July. № 10.

6. Runge V.F. Ergonomics and interior equipment. M., 2004.

7. Ustin V.B. Artistic interior design. Moscow, 2010.

8. Chavoyski R., Pershivy I. Our House. Bratislava, 1988.

(C) 2014, Ажгихин С.Г., Селезнева Т.В.

Специфика проектирования жилого помещения с учетом потребностей и интересов жильцов
(C) 2014, Azhgikhin S.G., Selezneva T.V.

Specific features of the premises design which meets the needs and interests of tenants 
DOI: $10.17117 /$ no.2014.01.050

Поступило в редакцию: 06.11.2014

rector@kubsu.ru

\title{
Ажгихин С.Г., Лисишина О.А. Специфика проектирования дизайна интерьера салона красоты
}

\author{
Azhgikhin S.G., Lisishina O.A. \\ Specific features of the beauty shop interior design
}

В статье затронута проблема создания дизайна интерьера для салона красоты, выявлены основные принципы создания дизайн-проекта, показана возможность их реализации в учебном процессе вуза в ходе профессиональной подготовки будущих дизайнеров. В статье правомерно отмечается, что разработка дизайн-проекта интерьера - это комплекс работ, направленный на создание и реализацию различных интерьерных решений. В статье показано, каких принципов и правил, в обязательном порядке, нужно придерживаться при разработке интерьера салона. Предлагается решение проблемы путем проектирования интерьера с учетом всех эргономических и эстетических требований к зонированию помещения, основные принципы дизайн-проектирования которого показаны на примере салона красоты «Золотые ножницы» Ключевые слова: профессиональная подготовка будущих дизайнеров, учебный процесс вуза, дизайн интерьера салона красоты, оформление салона красоты, проектирование салона красоты, индустрия красоты, зонирование помещения, дизайнерское решение

\section{Ажсгихн Сергей Геннадьевич}

Кандидат педагогических наук, доцент, профессор Кубанский государственный университет г. Краснодар, ул. Ставропольская, 149

\section{Лисишина Ольга Александровна} Магистрант

Кубанский государственный университет 2. Краснодар, ул. Ставропольская, 149
In the article the issue of creation of interior design for the beauty shop is discussed, the basic principles of creation of the design project are described and the possibility of their implication in the educational process in higher education institutions during the vocational training of future designers is shown. The author notes that the development of the design project of an interior is a complex of operations aimed at creation and implementation of various interior decisions. It is also shown in the article, what principles and rules should be followed when developing an interior of a salon. The problem is supposed to be solved by means of designing an interior taking into account all ergonomic and esthetic requirements to zoning of the room whose basic principles of design are shown on the example of a beauty shop "Gold Scissors"

Key words: vocational training of future designers, educational process of higher education institution, beauty shop interior design, beauty shop decoration, the design of the beauty shop, industry of beauty, zoning of the room, design decision

\section{Azhgikhin Sergey Gennadevich}

Doctor of Pedagogic Sciences, Professor, Head of Department

Kuban State University

Krasnodar, Stavropolskaya St., 149

\author{
Lisishina Olga Aleksandrovna \\ Undergraduate \\ Kuban State University \\ Krasnodar, Stavropolskaya St., 149
}


В статье представлены реализуемые проектные принципы, которые находят применение в учебном процессе вузов в ходе профессиональной подготовки будущих дизайнеров.

Гармоничный дизайн интерьера салона красоты оставляет одно из самых ярких впечатлений при первом посещении. Поэтому очень важно проектирование запоминающегося дизайна интерьера, это должно быть первой задачей для его владельцев. Дизайн интерьера салона красоты должен нравиться целевой аудитории, иначе даже самое дорогое и современное оборудование и высокий профессионализм персонала не спасет положение.

Зачастую при создании дизайна салона красоты больше внимания уделяют приобретению оборудования и перечню услуг, забывая о таком важном моменте, как интерьер и планировка, предпочитая ограничиться косметическим ремонтом в существующем помещении. Клиенты, как правило, приходят в конкретный салон за услугами понравившегося мастера, и, если условия работы не будут комфортны для этого специалиста, теряется не только персонал, но и клиенты, уходящие в другой салон вслед за мастером. Таким образом, в большинстве случаев люди посещают определенный салон красоты из-за какого-либо мастера, при этом не обращают внимание на дизайн помещения салона красоты.

Дизайн и оформление салона красоты считается второстепенным. Ставку салоны делают на мастеров и часто ошибаются, ведь атмосфера салона красоты, а, значит, настроение клиента и самих парикмахеров, напрямую зависит от дизайна интерьера.

Дизайн салона красоты - это совершенно отдельная тема в дизайне интерьеров. Салон красоты является тем типом помещений, которые изобилуют большим количеством специального оборудования, что привносит в проект салона множество технических нюансов.

Кроме правильно расставленной и красивой мебели при проектировании салонов красоты нужно уделить много внимания качеству материалов и рабочих поверхностей. Они должны быть не только привлекательными на вид, но также износостойкими и практичными.

Дизайн интерьера - это своего рода «упаковка», на нее в первую очередь обращают внимание. Товар в красивой упаковке продать гораздо легче, чем без нее. Большинство людей судят по услуге, исходя из того, что они видят. А так как зрительное восприятие часто играет наиболее важную роль, то человек гораздо быстрее поверит своим глазам, чем любым другим аргументам.

Дизайн интерьера салона красоты должен быть не только ярким и запоминающимся, но и быть правильно оборудованным, иметь достаточную освещенность, чтобы мастера могли качественно выполнить свою работу. Ведь в такие заведения люди приходят, в первую очередь, за оказанием услуг, которые желают получить в приятной обстановке.

Дизайн может радовать глаз своей необычайностью и, в то же время, практичностью. И, не смотря на то, что в некоторых случаях архитектура помещения не соответствует концепции заведения, к проектированию салонов красоты можно подойти творчески и найти выход из сложившейся ситуации. 
Порой недостатки помещения можно превращать в достоинства, главное творческий подход.

Идеально создавать сначала интерьер салона, а затем приступать к его строительству, но, к сожалению, такое не всегда возможно. Очень часто приходится открывать салон в имеющемся помещении. В таком случае, скорее всего, придется затевать перепланировку, найти наиболее приемлемое расположение мест для работы разных мастеров [5].

При разработке дизайн-проекта салона необходимо учитывать в обязательном порядке:

- эргономику,

- колористическое решение,

- качественную вентиляционную систему,

- поддержание комфортного температурного режима в любое время года,

- правильно рассчитать освещение, особенно рабочих зон,

- рассчитать максимальную нагрузку на электросеть,

- возможность подводки водопровода и канализации практически во все помещения салона и т.д.

- надо хорошо разбираться в назначении и потребностях того или иного кабинета (эстетических и практических),

- соблюдать рекомендации СЭС по устройству помещений парикмахерских.

Проигнорировав или неверно рассчитав какой-то пункт из этого списка, потом, к сожалению, можно приобрести множество проблем. Нет сомнения, что качественный дизайн-проект, сам ремонт и, особенно, прокладка инженерных коммуникаций, очень не дешевое удовольствие. Однако надо помнить, что в салоне мелочей не бывает.

Разработка дизайн-проекта интерьера - это комплекс работ, направленный на создание и реализацию различных интерьерных решений. Составляя дизайн-проект, надо учитывать тот факт, что любое помещение должно быть не только красиво оформлено, но комфортабельно [6].

Проектируя салон красоты, требуется создать такие условия для обслуживания клиентов и сотрудников, при которых повышается производительность труда, комфорт клиентов, снижается утомляемость, поддерживается хорошее настроение и др.

Доброжелательное отношение персонала к клиентам невозможно, если в течение дня сотрудники устали от неэффективной организации труда, да и количество клиентов будет обслуживаться меньшее, поэтому требуется внимательно продумать рабочий процесс, функциональность каждого кабинета и максимально оптимизировать работу и услуги [1]. Следует тщательно спланировать интерьер салона красоты, так как он очень сильно будет оказывать влияние на посещаемость.

Рассмотрим некоторые наиболее интересные салоны красоты во всем мире. "Небесный" релаксирующий салон красоты в Корее напоминает некое облако, в котором можно расслабиться и приятно провести время, а так же возвратиться сюда снова и снова. Дизайнеры архитектурной студии SPASM 
Design Architects создали "небесный" интерьер корейского салона красоты под названием «Permy Mi Jang Won» (рис.1), который находится на одной из шумных улочек Судзи-гу (Корея). Этот салон красоты оформлен в нежных белоголубых тонах. Помещение салона имеет основную зону, где работает персонал, а также зону отдыха и релаксации для посетителей.

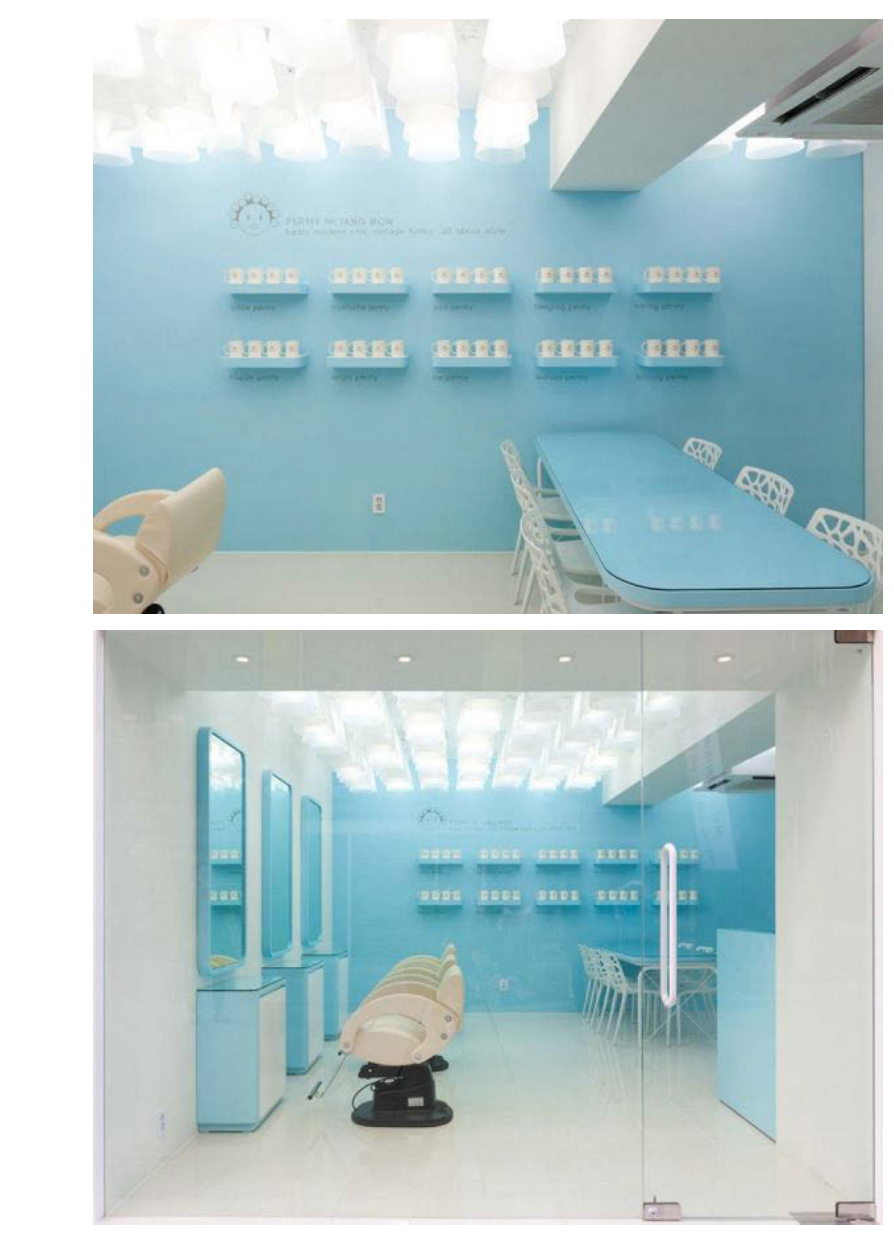

Рис.1 Салон красоты «Permy Mi Jang Won» в Kopee

Дизайн этого салона красоты настолько свеж и "воздушен", что его в действительности можно назвать "небесным" салоном красоты и по-настоящему расслабиться. Помещение салона красоты отделано голубыми и белыми материалами, зеркалами. Все это создает ощущение воздушных облаков, медленно "плывущих" по небу. Релаксация в таком салоне будет очень эффективной!

Еще один необычный салон красоты «end...Link» в Японии от архитектора Ясунари Цукада (Yasunari Tsukada). Полностью белое пространство, в котором нет ничего, кроме решеток из дерева, сконфигурированных между собой в полки, столешницы, стулья, системы освещения и держатели зеркал (рис.2).

Салон красоты занимает длинное и узкое здание, поэтому архитектором Ясунари Цукада был разработан чистый белый интерьер с тем, чтобы сохранить имеющееся пространство максимально открытым и визуально увеличить его. Сетчатая стенка из древесины проходит по правой стороне данного ме- 
стечка для создания рабочих мест для семи стилистов. "Нам стало интересно, можем ли мы создать гибкую, расширяемую, стену, не накладывая никаких ограничений на ее функциональность", - объясняет архитектор. "В данном случае нам сыграли на руку трехмерные экраны-решетки, напоминающие части джунглей, а также тренажерный зал, части которого функционируют как архитектурные предметы мебели".

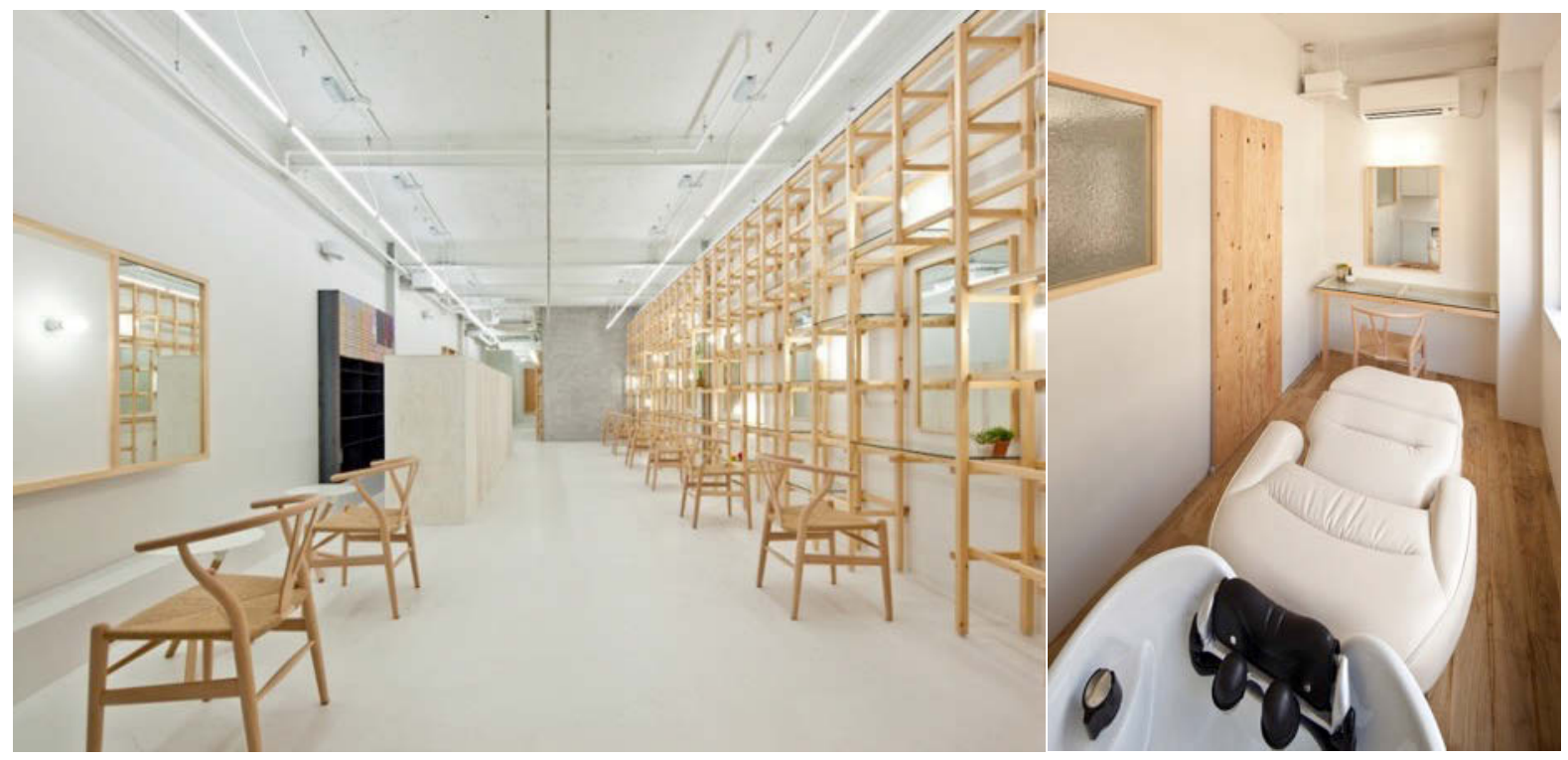

Pис.2 Салон красоты «еnd...Link» в Японии от архитектора Ясунари Цукада

Отверстия в сетке создают пространство для зеркал, а подвесные светильники можно повесить сверху, вставить в стеклянные панели или прямо в стеллажи макета. Два дополнительных сиденья обращены к большому зеркалу на противоположной стене, в то время как экран смотрит прямо на стойку регистрации. Более узкий деревянный каркас обеспечивает дополнительные полки в направлении задней части 28-метрового зала, а блоки для мытья волос спрятаны в задней части пространства.

Рассмотрев два этих примера (аналога) можно сказать, что интерьеры этих салонов красоты совершенно противоположны по стилистике, но, в то же время, очень уютны и комфортабельны.

Салонов красоты существует на рынке индустрии красоты огромное количество, но, к сожалению, далеко не все салоны красоты соответствуют всем нормам и могут похвастаться уникальным дизайном интерьера и индивидуальностью. Особенно это остро заметно в маленьких городах, где все салоны красоты как будто делал один человек, и они просто обставлены мебелью.

Рассмотрим существующую проблему на примере дипломного проекта. Актуальность темы заключалась в разработке дизайна интерьера салона красоты «Золотые ножницы». В городе Приморско-Ахтарске, Краснодарского края достаточно различных салонов красоты, но все они очень похожи по внутренней отделке помещения и имеют проблему несоответствия данного типа заведения с установленными нормами и правилами. Именно поэтому при помощи правильного проектирования интерьера и с учетом потребностей целевой 
аудитории было решено исправить положение салона красоты «Золотые ножницы» и выделить его среди конкурентов.

Салон красоты «Золотые ножницы» приобрёл значительную популярность среди потребителей. В салоне присутствовали хорошо обученные мастера, умеренные цены, индивидуальный подход к каждому клиенту. Но интерьер салона красоты оставлял желать лучшее, а оформление фасада - безликое и эстетически не привлекательное. А ведь от удачно подобранного интерьера салона красоты напрямую зависит его прибыльность.

Дизайн интерьера красоты должен быть стильным. Это аксиома. Ни одна женщина не доверит свою прическу, а тем более лицо мастеру, который будет работать на «допотопном» оборудовании в окружении старой мебели [3].

Во время предпроектного анализа салона красоты «Золотые ножницы» выявились большие проблемы, связанные с зонированием помещения. Все зоны размещены хаотично и не сразу можно понять, какая зона к какому виду услуг относится. Все, практически, у всех на виду и нет возможности у клиентов салона красоты полностью расслабиться, отдохнуть и получить необходимые услуги. Многие зоны необходимо уединены, так как приводит к дискомфорту посетителей салона.

Интерьер салона красоты «Золотые ножницы» не оказывает никаких положительных эмоций на посетителей. Стены выкрашены в бежевый цвет, как в большинстве салонов красоты города Приморско-Ахтарска, на полу белая плитка, синие кресла для оказания парикмахерских услуг и белые столы. На окнах бежевые жалюзи, которые всегда закрыты и давно уже выгорели на солнце. На стенах висит несколько постеров.

При входе в салон красоты посетитель видит не стойку с приветливым администратором, а мойку для волос, что очень неудачно и не эстетично, так как многие посетителям это не совсем приятно и вводит неловкое положение обоих посетителей салона красоты.

А ведь некоторые зоны необходимо уединить, какие-то оставить на виду или наоборот. Каждая зона должна нести определенную функцию. Необходимо сделать акцент на одной из зон. Проблема зонирования выходит на первый план. Так же были проблемы с освещением и микроклиматом помещения. Необходимо также было решить проблемы системы вентиляции помещения, ведь если в салоне будут присутствовать резкие запахи ацетона, окислителей и других химических средств, вряд ли клиент придет в салон во второй раз.

Главной целью интерьера салона красоты является то, что за счет нового проектирования интерьера должны решаться проблемы зонирования, устаревшего, некачественного оформления и оборудования, плохого освещения, загромождения лишними предметами, трудной проходимости, отсутствия зоны ресепшн и ожидания, что является неотъемлемой немаловажной частью салона.

В итоге предпроектного анализа было решено в салоне красоты «Золотые ножницы» использовать спокойные, теплые тона, без резких форм и ярких цветов. В качестве основного цвета выбран теплый оттенок, коричневогокамелопардовый цвет (желтовато-коричневый). Коричневый символизирует 
заботу, надежность, простоту и стабильность. В дополнении к камелопардовому цвету был выбран белый цвет, так как белый делает коричневый более насыщенным и выразительным, в то время как коричневый лишает белый цвет нейтральности и стерильности.

Основным акцентом в проектировании дизайна интерьера салона красоты будет являться декоративная перегородка, которая привнесет в интерьер необычность и индивидуальность, что придаст интерьеру салона красоты отличительную особенность от конкурентов.

Главным в проектировании дизайна интерьера салона красоты является зонирование помещения. От этого будет зависеть удобство работы мастеров и комфортность посетителей, что сделает помещение еще уютнее и комфортабельнее. Существует огромное множество вариантов зонирования, которые достигаются методом установки стационарных или передвижных перегородок, с помощью занавеса, а также с помощью различных отделочных материалов, различного освещения, изменения высоты потолка или уровня пола. Для салона красоты была выбрана интерьерная декоративная перегородка, выполненная по индивидуальным эскизам. Интерьерные декоративные перегородки - конструкции, которые одновременно выполняют две функции, а именно разделяют пространство на функциональные зоны и украшают интерьер.

В салоне красоты использовано только новейшее оборудование и удобная мебель, как для посетителей, так и для мастеров, что позволит мастерам выполнять свою работу качественнее, а посетители салона смогут расслабиться и получать необходимые для них услуги.

В отделке помещения используются только самые современные и безопасные материалы и покрытия, которые хорошо моются и прослужат не один год, что очень важно для данного типа заведения.

Помещение салона красоты обеспечено отличной вентиляцией и кондиционированием, что создаст благоприятный климат и от чего будет зависеть комфорт, как посетителей, так и мастеров салона красоты.

Так же необходимо обеспечить грамотное освещение помещение, что очень важно для салона красоты, так как мастерам, работающим в данной сфере необходим правильный, грамотно выстроенный свет, от чего зависит качество выполненной работы и удовлетворенность клиента.

Основной задачей в проектировании дизайна помещения салона красоты «Золотые ножницы» - создание особой и уютной атмосферы, чтобы салон ценился не только квалифицированными мастерами, но и своим интерьером, который сможет привлекать все новых и новых клиентов.

Были решены поставленные перед проектом цели и задачи. А именно:

- разработан новый стильный интерьер салона красоты «Золотые ножницы», соответствующий концепции салона;

- была решена проблема с зонированием помещения (многие зоны стали уединенными, что делает салон красоты комфортнее);

- появилась зона ресепшн (теперь посетители не будут в растерянности при входе в салон красоты, не зная к кому обратиться); 
- была решена проблема зоны мойки для волос (теперь она не на видном месте и не стесняет клиентов);

- появилось место для отдыха (ожидания), где можно полистать журнал и посмотреть ТВ.

В дизайне интерьера салона красоты важным акцентом является освещение. Как правило, общее освещение должно дополняться локальным. Продумывая установку локальных светильников, необходимо учесть расположение столов, кресел и оборудования.

Цвет играет в жизни человека немаловажную роль. Хорошо подобранные цвета интерьера салона красоты будут вызывать у посетителей позитивный настрой, способствовать отдыху и расслаблению. В противном случае, неправильно подобранные цвета могут вызвать состояние дискомфорта.

Важно в проектировании интерьера салона красоты правильно и грамотно совмещать функциональность с эстетикой. Ведь в салоне красоты очень важно правильное зонирование всех зон и комфортное перемещение.

Успешный салон красоты должен иметь свой образ, который позволит привлечь и завоевать доверие клиента. Все должно быть гармонично от продуманного дизайна интерьера, включая удобное парикмахерское оборудование. Безликие помещения, даже наполненные самыми новомодными инструментами, одинаковые светлые панели, жалюзи под «евро» и полное отсутствие индивидуальности оставят в памяти клиента такой же «безликий» след. Поэтому очень важно найти индивидуальный стиль салона красоты. Все это учитывалось при проектировании салона красоты «Золотые ножницы» в городе Приморско-Ахтарске.

Важный аспект, на котором базируется дизайнерское решение - эргономический, привязывающий это решение к возможностям и особенностям человеческой натуры, в том числе социальным и психологическим [4].

При проектировании дизайна интерьера подготовительный этап особенно важен, так как дизайн интерьера непосредственно выполняет функцию влияния на человека по средствам цветового решения, стилизации, освещения, фактуры и других не менее важных показателей. Специалист по дизайну должен грамотно раскрыть потребности заказчика и учесть его индивидуальные потребности. Именно системный подход определяет ключевые точки, по которым можно фиксировать данные, а далее подвергать их тщательному анализу [2].

Можно сделать вывод, что дизайн - это система, которая соединяет множество наук и процессов. Эта, относительно стройная система теоретических положений, не выглядит определенной, так как в дизайнерском творчестве нет устойчивых предпочтений каких-либо средств выразительности - они легко подменяют друг друга.

Представленные в статье реализуемые проектные принципы, ориентированные на оптимальное использование в учебном процессе вуза в ходе профессиональной подготовки будущих дизайнеров, так как выявлены основные принципы создания дизайн-проекта интерьера салона красоты и показана возможность их реализации. 


\section{Список литературы:}

1. Ажгихин С.Г., Марченко М.Н. Типы принятия решений в процессе проектной деятельности // 21 century: fundamental science and technology. Vol. 2. North Charleston, 2014. C. 86-89.

2. Зинченко В.П., Мунипов В.М. Основы эргономики. М., 2000.

3. Кирьянко Е.А., Сухарев Е.Н. Системный подход к проектированию дизайна интерьера. URL: http://sibac.info/index.php/2009-07-01-10-21-16/908-2012-01-29-06-48-35/23.11.14

4. Колин К. Интерьер салона красоты. М., 2000.

5. Основные правила дизайна интерьеров. URL: http://www.piter-design.ru/15.11.14

6. Проект IDH - Пространство и стиль. URL: http://www.idh.ru/15.11.14

7. Эйвис Дж., Эйвис М. Интерьер. Выбираем цветовой дизайн. М., 2006.

\section{References:}

1. Azhgikhin S.G., Marchenko M.N. Types of decision-making in the project activities //21 century: fundamental science and technology. Vol. 2. North Charleston, 2014. Pp. 86-89.

2. Zinchenko V.P., Munipov V.M. Fundamentals of ergonomics. M., 2000.

3. Kiryanko E.A., Sukharev E.N. A systematic approach to interior design. URL: http://sibac.info/index.php/2009-07-01-10-21-16/908-2012-01-29-06-48-35/23.11.14

4. Colin K. Interior beauty. M., 2000.

5. The basic rules of interior design. URL: http://www.piter-design.ru/15.11.14

6. Draft IDH - Space and Style. URL: http://www.idh.ru/15.11.14

7. Avis J., Avis M. Interior. Choosing a color design. M., 2006.

(C) 2014, Ажгихин С.Г., Лисишина О.А.

Специфика проектирования дизайна интерьера

салона красоты
(C) 2014, Azhgikhin S.G., Lisishina O.A.

Specific features of the beauty shop interior design 
DOI: $10.17117 /$ no.2014.01.059

Поступило в редакцию: 23.11.2014

office@technolog.edu.ru

\title{
Берсенева Н.В.
}

\section{Учебная дисциплина «Психология и педагогика» \\ в системе подготовки студентов-экономистов}

\author{
Berseneva N.V. \\ Discipline "Psychology and pedagogy» \\ in the training students of economics
}

В статье представлена методика преподавания психологии и педагогики в системе подготовки студент экономистов техническом вузе, обосновывается специфика преподавания учебной дисциплины и значимости изучения данного курса в подготовке специалистов экономического профиля. Рассмотрены современные требования к преподаванию психолого-педагогических дисциплинам технических вузов

Ключевые слова: интерактивный подход, учебнонаучно-методическое обеспечение, направления: психолого-педагогическое, личностнопознавательное, практико-прогностическое

\section{Берсенева Надежда Васильевна}

Кандидат педагогических наук, доцент

Санкт-Петербургский государственный технологический институт

2. Санкт-Петербург, Московский проспект, 26
The paper presents a methodology of teaching psychology and pedagogy in the training of technical college student economists, grounded specificity teaching of the discipline and the importance of this course in training specialists in economics. The modern requirements for the teaching of psychopedagogical disciplines of technical colleges

Key words: interactive approach, educational, scientific and methodological support, areas: psychological and educational, personal and cognitive, practical-predictive

\section{Berseneva Nadezhda Vasilievna \\ Candidate of Pedagogic Sciences, associated Professor \\ St. Petersburg State Technological Institute Saint Petersburg, Moskovsky pr. 26}

Современные требования, возлагаемые на студентов технических вузов с точки зрения содержания учебно-методического обеспечения программ по психологии и педагогики, во многом должны быть гарантом убеждения в необходимости их получения. Приобретенные психолого-педагогические знания должны войти в систему мировосприятия, практического мышления образованного человека, его внутренних установок и привычек, использоваться как инструмент при решении жизненных проблем и профессиональной деятельности.

В действующих ФГОС ВПО бакалавриата, по сравнению с ГОС ВПО специалистов, существенно уменьшилось количество часов, отводимых на реализацию курсов гуманитарных и социальных дисциплин, что ставит перед преподавателями вузов серьёзнейшую проблему, связанную с пересмотром и изменением подходов к преподаванию. 
Привлекательная специфичность психологии и педагогики выражается в том, что при изучении этой дисциплины студент должен получить представление о природе психики человека, знать основные психические функции и их физиологические механизмы, соотношение природных и социальных факторов в становлении психики; знать в каких формах происходит освоение человеком действительности, понимать роль сознания и самосознания в поведении, деятельности, формировании личности; понимать значение воли, эмоций, потребностей и мотивов; уметь дать психологическую характеристику личности, интерпретировать собственные психические состояния, владеть простейшими приемами психической саморегуляции; осознавать закономерности межличностных отношений в быту и организованном коллективе; знать формы, средства и методы психологической деятельности; владеть элементарными навыками анализа учебно-воспитательных ситуаций, определения и решения педагогических задач, как в семье, так и в трудовом коллективе.

Материал, предлагаемый как в лекционной, так и в практической форме должен обеспечить интерес студентов к психологии и педагогике как наукам, связанных со всеми сферами человеческой деятельности, в том числе и экономической.

Современные требования к психолого-педагогическим дисциплинам технических вузов можно представить в виде следующих основных направлений:

- теоретическое психолого-педагогическое направление (лекционной материал, самостоятельное изучение научной литературы);

- личностно-познавательное (практикум на основе современнных методов изучения индивидуально-психологических свойств личности);

- практико-прогностическое (обеспечение уверенностью будущих экономистов-специалистов в выборе своей специальности; приобретение и закрепление навыков общения в личностном пространстве поло-ролевого поведения; развитие навыков в приобретении «психологических защит», снижающих уровень невротизации личности студента).

Теоретическое психолого-педагогическое направление в технических вузах должно реализовываться за счёт современных данных о состоянии новшеств в рамках психологических и педагогических теорий, объясняющих в той или иной мере происхождение, механизмы развития, уровни проявления психических явлений связанных с профессиональной деятельностью будущих экономистов. Это направление должно охватывать как теоретические, так и практические основы профессионального обучения и развития.

Личностно-познавательное направление может быть реализовано во многом посредством методов психолого-педагогических исследований, связанных не только с личностью студентов технических вузов, но и с их направлением подготовки. Так темы для исследования могут быть следующими: речевые коммуникации в деловых переговорах; роль денег в жизни молодежи; нетворкинг как инструмент расширения бизнеса; реклама как инструмент манипуляции сознанием; НЛП (нейро-лингвистическое программирование) для 
успеха, карьеры, бизнеса; производственный менеджмент: стратегии поведения в трудовых отношениях и др.

Исследования личностных качеств студентов позволяет выявить индивидуальные особенности эмоциональной, познавательной и волевой сферы будущих специалистов. Все эти знания о личности будущего специалиста экономиста позволят определить стиль его профессиональной деятельности, проектировать деятельность экономиста в системе человек - машина, человекчеловек.

Практико-прогностическое направление представлено целым комплексом различных методов оценки личности специалиста в различных жизненных ситуациях.

Изучаемый материал курса «Психология и педагогики» строится на основе следующих теорий и концепций обучения: проблемного обучения (Д. Дьюи, С.И. Архангельский, Л.Я. Лернер, А.М. Матюшкин, М.И. Махмутов, М.Н. Скаткин); развивающего обучения (В.В. Давыдов, Л.В. Занков, Д.Б. Эльконин); контекстного обучения (А.А. Вербицкий), личностно - деятелъностного и личностно - ориентированного обучения (И.А. Зимняя, И.С. Якиманская); активного обучения (Б.Т. Ананьев, Н.А. Бердяев, JI.С. Выготский, Н.А. Добролюбов, А.Н. Леонтьев, JI.М. Лопатин, А.С. Макаренко, С.Л. Рубинштейн, В.А. Сухомлинский, К.Д. Ушинский, Н.Г. Чернышевский и др.).

Особое значение в преподавании психологии и педагогики отводится интерактивному подходу (диалогический характер) для формирования внутренней учебной мотивации студентов, который должен «видеть»материал не как нечто абстрактное по отношению к нему, а то, что возможно будет связано с ним и его жизнью. Лекционные и семинарские занятия проводятся таким образом, чтобы студенты ощущали себя непосредственными участниками происходящего. Практикуются следующие лекции по форме организации: информационные, проблемные, лекции-визуализации, лекции-вдвоем, лекции с заранее запланированными ошибками, пресс-конференции, лекция с применением обратной связи, лекция с опорным конспектированием, лекции «наоборот» (тема лекции изучается самостоятельно, а на лекции проводится совместное изучение на конкретных примерах) и др.

В лекции «вдвоем» учебный материал проблемного содержания дается студентам в живом диалогическом общении двух преподавателей между собой, возможно с привлечением студентов. В ходе лекции моделируются реальные профессиональные ситуации обсуждения теоретических вопросов с разных позиций двумя специалистами, например теоретиком и практиком, сторонником или противником той или иной точки зрения, при этом в процесс обсуждения должны активно вовлекаться студенты.

Лекция «вдвоем» активизирует мыслительную деятельность студентов. При представлении двух или нескольких источников информации задача студентов - сравнить разные точки зрения и сделать выбор, присоединиться к той или иной из них или выработать свою позицию.

В холе преподавания семинаров практикуются следующие виды: просеминар (работа с научной литературой, написание докладов рефератов, эссе). 
собственно семинар, спецсеминар (углубленное изучение отдельных тем, возможно связанных с различными исследованиями). Привлекают студентов семинары по форме проведения таких как: диспут, мозговой штурм, круглый стол, дискуссия, деловая игра, анализ литературы, семинар по материалам исследования, проведенного студентами, моделирование ситуаций и др.

Серьезной подготовки требуется для проведения системного семинара, который проводятся для более глубокого знакомства с разными проблемами, имеющие отношение к изучаемой теме. Например: «Система воспитания трудовой и социальной активности», «Конфликтогенные факторы в отечественном образовании» и др.

Метод системных семинаров раздвигает границы знаний студентов, помогает выявить причинно-следственные связи различных социальнопсихологических и педагогических явлений, вызывает интерес к изучению различных сторон общественно-экономической жизни.

В русле данного направления подготовки будущих специалистов экономистов особенности поведения личности и их прогностическая сторона очень важны, так как деятельность в профессиональной сфере и вне ее во многом взаимосвязана. Например, позитивная оценка достижений личности, вне профессиональной сферы, может позитивно повлиять на результаты профессиональной деятельности. Объясняется данная взаимосвязь теорией А. Маслоу, где потребности признания для каждой личности имеют особую значимость наряду с другими потребностями (физиологическими, социальными, защищенности и т.д.).

Таким образом, качество преподавания и усвоение психологии и педагогики как учебной дисциплины в техническом вузе, а также осознание студентами значимости изучаемого курса значительно повысится, если:

- оно основывается на современных достижениях вузовской дидактики, авторской концепции и авторской программе, апробированной непосредственно в учебном процессе, учебно-научно-методическим обеспечением преподаваемой дисциплины;

- преподавание учебной дисциплины будет осуществляться на основе теории игр; моделирования; теории сложности с систематическим использованием проблемных задач, приближенных к реалиям современных социально - экономических отношений; логики.

\section{Список литературы:}

1. Беляева Л.А. Образование в России и модернизация экономики (по результатам Европейского социального исследования). URL: http://www.isras.ru/files/File/Socis/2011-12/Beliaeva.pdf

2. Дружилов С.А. Основы практической психологии и педагогики для бакалавров. М. Флинта, 2013.

3. Ломов Б.Ф. Вопросы общей, педагогической и инженерной психологии. М.: Педагогика, 1991.

4. Немов Р.С. Психология. М.: Юрайт, 2010. 639 с.

5. Панфилова А.П. Инновационные педагогические технологии: Активное обучение. М.: Академия, 2012. $191 \mathrm{c.}$

6. Столяренко П.Д., Столяренко В.Е. Психология и педагогика для технических вузов. Ростов-на-Дону: Феникс, 2001. 
References:

1. Belyaeva L.A. Education in Russia and modernization of the economy (according to the European Social Survey). URL: http://www.isras.ru/files/File/Socis/2011-12/Beliaeva.pdf

2. Druzhilov S.A. Fundamentals of practical psychology and pedagogy for bachelors. M. Flint, 2013.

3. Lomov B.F. Questions of general, pedagogical and engineering psychology. M.: Pedagogy, 1991.

4. Nemov R.S. Psychology. M.: Yurayt, 2010. 639 p.

5. A. Panfilov P. Innovatsionnye educational technology: Active learning. Moscow: Academy, 2012. 191 p.

6. Stolyarenko P.D., Stolyarenko V.E., Psychology and Pedagogy for technical colleges. Rostov-on-Don: Phoenix, 2001.

(C) 2014, Берсенева Н.В.

Учебная дисциплина «Психология и педагогика» 8 системе подготовки студентов-экономистов
(C) 2014, Berseneva N.V.

Discipline «Psychology and pedagogy» in the training students of economics 
DOI: $10.17117 /$ no.2014.01.064

Поступило в редакцию: 05.11.2014

info@gup.ru

Волкова Е.В.

\author{
Использование современных информационных и \\ инновационных технологий при обучении студентов \\ теории и практике межкультурной коммуникации
}

\author{
Volkova E.V. \\ Use of modern information and innovative technologies while \\ teaching theory and practice of intercultural communication \\ to university students
}

В статье рассматриваются возможности использования современных информационных и инновационных технологий при обучении студентов вузов теории и практике

межкультурной коммуникации; описываются используемые приёмы

Ключевые слова: информационные технологии, инновационные технологии, межкультурная коммуникация

Волкова Елена Викторовна

кандидат педагогических наук,

доцент кафедры, зам. заведующего кафедрой

Санкт-Петербургский Гуманитарный

Университет Профсоюзов

2. Санкт-Петербург, ул. Фучика, 15

\begin{abstract}
The article deals with description of the use of modern information and innovative technologies while teaching theory and practice of intercultural communication to university students; describes the techniques used for that
\end{abstract}

Key words: information technologies, innovative technologies, intercultural communication

\author{
Volkova Elena Victorovna \\ Candidate of Pedagogic Sciences, associate Professor, \\ Deputy Chair of Department \\ St. Petersburg University of Humanities and Social \\ Sciences \\ St. Petersburg, Fuchika str., 15
}

Одной из приоритетных задач государственной политики в области образования является обеспечение инновационного характера базового образования. Внедрение и эффективное использование новых информационных сервисов, систем и технологий обучения, электронных образовательных ресурсов нового поколения включено в Федеральную целевую программу развития образования на 2011-2015 годы. Использование информационных и инновационных технологий в образовании способствует формированию специалиста нового поколения, соответствующего требованиям современного общества и, в частности, работодателя.

Говоря об информационных и инновационных технологиях обучения, необходимо сначала рассмотреть само понятие педагогической технологии. Понятие педагогической технологии имеет различные трактовки. Так, в учеб- 
никах по педагогике существует несколько определений педагогической технологии:

- Педагогическая технология - это содержательная техника реализации учебного процесса (В.П. Беспалько).

- Педагогическая технология - это описание процесса достижения планируемых результатов обучения (И.П. Волков).

- Педагогическая технология - это продуманная во всех деталях модель совместной педагогической деятельности по проектированию, организации и проведению учебного процесса с безусловным обеспечением комфортных условий для учащихся и учителя (В.М. Монахов).

- Педагогическая технология - это последовательная взаимосвязанная система действий педагога, направленная на решение педагогических задач; планомерное и последовательное воплощение не практике заранее спроектированного педагогического процесса; строго научное проектирование и точное воспроизведение гарантирующих успех педагогических действий (В.А. Сластёнин).

В педагогической практике педагогические технологии представлены технологиями обучения и технологиями развития. Нас интересуют оба аспекта педагогических технологий, так как для формирования компетенций согласно ФГОС ВПО требуется как обучение студентов, так и развитие у них определённых качеств.

В своей работе мы рассматриваем педагогическую технологию на частнометодическом (предметном) уровне. Инновационные педагогические технологии, таким образом, представляют собой совокупность инновационных методов и средств для реализации определённого содержания обучения, воспитания и развития в рамках одного предмета, студенческой группы, преподавателя. Под информационными технологиями в последнее время чаще всего понимают компьютерные технологии.

В учебном плане по направлению подготовки «Лингвистика» (профиль подготовки «Теория и практика межкультурной коммуникации») присутствуют две дисциплины, связанные с межкультурной коммуникацией - «Основы теории межкультурной коммуникации» и «Практикум по межкультурной коммуникации». Несмотря на то, что первая дисциплина читается на русском, а вторая на иностранном (в нашем случае английском) языке, мы рассматриваем преподавание данных дисциплин в комплексе.

При преподавании межкультурной коммуникации студентамлингвистам необходимой является разработка курсов в Системе поддержки самостоятельной работы студентов - Moodle. Это связано не только с удобством использования данной системы в педагогическом процессе, но и с объективной необходимостью иметь возможность предоставлять студентам свежую информацию по исследованиям в данной сфере, которую невозможно найти в учебниках.

Целью курса «Основы теории межкультурной коммуникации» является формирование, развитие и усовершенствование специальных компетенций в сфере межкультурной коммуникации. В задачи учебного курса входит: 
- обеспечение межкультурного общения в различных профессиональных сферах;

- выполнение функций посредника в сфере межкультурной коммуникации;

- выявление и критический анализ конкретных проблем межкультурной коммуникации, влияющих на эффективность межкультурных и межъязыковых контактов;

- проведение эмпирических исследований проблемных ситуаций и диссонансов в сфере межкультурной коммуникации;

- применение тактик разрешения конфликтных ситуаций в сфере межкультурной коммуникации;

В результате изучения дисциплины студент должен:

- иметь представления: об этических и нравственных нормах поведения, принятых в инокультурном социуме, о моделях социальных ситуаций, типичных сценариях взаимодействия;

- знать: теоретические основы межкультурной коммуникации; методики, позволяющие преодолевать влияние стереотипов и адаптироваться к изменяющимся условиям при контакте с представителями различных культур;

- уметь: моделировать возможные ситуации общения между представителями различных культур и социумов; преодолевать влияние стереотипов и осуществлять межкультурный диалог в общей и профессиональной сферах общения;

- владеть: международным этикетом в различных ситуациях межкультурного общения (сопровождение туристических групп, обеспечение деловых переговоров, обеспечение переговоров официальных делегаций и т.п.)

В разработанном нами учебно-методическом комплексе по дисциплине «Основы теории межкультурной коммуникации» особое внимание уделено методическим рекомендация по самостоятельной работе студентов. Курс разделён на десять тем:

- Теоретические основы межкультурной коммуникации;

- Возникновение и развитие межкультурной коммуникации;

- Психологический аспект межкультурной коммуникации;

- Социокультурный и исторический аспекты межкультурной коммуникации;

- Языковой аспект межкультурной коммуникации;

- Теории межкультурной коммуникации;

- Методы исследования в межкультурной коммуникации;

- Проблема понимания в межкультурной коммуникации;

- Межкультурная компетенция;

- Межкультурная коммуникация в различных сферах жизни.

Все десять тем объединены единым годовым проектом, который студенты выполняют в мини-группах. Для реализации проекта необходимо выбрать культуру для презентации и анализа с точки зрения изучаемой информации по всем темам курса. Проверка - презентация проекта на последнем занятии кур- 
са в конце шестого семестра, а также подробная презентация частей проекта по ходу курса.

План презентации проекта:

- Таблица сравнения культурных реалий (по Дж. Мердоку).

- История культурных контактов.

- Сравнительный анализ концептов.

Характеристика выбранной культуры с точки зрения теорий Э. Холла, Г. Хофстеде и Р. Льюиса (возможны и другие авторы).

Результаты, полученные при презентации выбранного метода коммуникативных исследований.

Результаты дискурс-анализа (если проведён анализ фильма, созданного в стране исследуемой культуры).

Для выполнения заданий по проекту студентам необходимо использовать компьютерные технологии, и не только поисковые системы, но и, например, социальные сети. Для выполнения задания №3 - сравнительного анализа концептов, студентам необходимо связаться с представителями выбранной культуры для получения ассоциативного ряда, связанного с выбранным концептом. Задание осуществляется по следующему плану: Цель концептологического анализа - описание концепта как ментального образования, элемента концептосферы лингвокультурного сообщества.

План анализа:

1. Семантический анализ слов, называющих имена концептов;

2. Этимологический анализ слов-репрезентантов концепта, направленный на определение их мотивирующих признаков;

3. Семантический анализ переносных, ассоциативных значений слов, номинирующих концепты;

4. Интерпретативный семантический анализ контекстов, в которых реализуются слова и словосочетания, обозначающие и выражающие концепты;

5. Интерпретативный культурологический анализ ассоциаций, связанных с определённым концептом;

6. Интерпретативный анализ ценностно-маркированных высказываний (пословиц, афоризмов, цитат), которые выражают определённые концепты;

7. Анализ коротких сочинений, написанных информантами на тему, соответствующую содержанию изучаемого концепта;

8. Анализ ассоциативных реакций информантов на вербальные обозначения концепта.

(пункты 7 и 8 - по возможности).

Если у студентов нет контактов в выбранной культуре, их предоставляет преподаватель. Для этого в самом начале проекта студентам рекомендуется выбирать из тех культур, с представителями которых они смогут связаться, или из списка, предложенного преподавателем (двадцать национальных культур).

Выполнение задания № 6 требует просмотра кинофильма, что невозможно без современных видео- и компьютерных технологий. Для выполнения задания необходимо выполнить дискурс-анализ отрывка из зарубежного 
фильма, интерпретирующего русский первоисточник, или из российского фильма, интерпретирующего зарубежный первоисточник. Дискурс-анализ в данном случае выступает как средство интерпретации культурных смыслов.

Параметры дискурс-анализа:

- Участники сообщения:

- Физиологическая, психологическая, социальная идентичность;

- Статус;

- Отправитель или получатель информации;

- Характер самоидентификации;

- Уровень коммуникативной, лингвистической и культурной компетенции;

- Взаимоотношения между коммуникантами;

- Контекст сообщения;

- Форма коммуникации;

- Содержательная составляющая:

- Тема говорящего;

- Тема дискурса;

- Экспликатура;

- Импликатура;

- Референция;

- Инференция;

- Пресуппозиция;

- Сценарная составляющая;

- Социально-интерактивная составляющая;

- Эмоциональная составляющая.

Предлагаемые фильмы для анализа:

- Anna Karenina (2012 г., режиссёр Джо Райт);

- The Brothers Karamazov (1958 г., режиссёр Ричард Брукс);

- Doctor Zhivago (1965 г., режиссёр Дэвид Лин);

- Onegin (1999 г., режиссёр Марта Файнз);

- War and Peace (1956 г., режиссёры Кинг Видор и Марио Сольдати).

Кроме выполнения годового проекта по курсу, система Moodle помогает в организации обсуждения различных вопросов по темам курса на форумах. Такой формат обсуждения важен для повышения активности тех студентов, для которых участие в аудиторных дискуссиях может представлять определённые психологические трудности, а также для дискуссий, для развития которых не хватило аудиторных часов. Всегда находятся новые нюансы, новые статьи по данной теме, и т.д.

Курс «Практикум по межкультурной коммуникации» включает в себя двенадцать тем:

1. Culture and Intercultural Interaction;

2. Intercultural Interaction Competence;

3. Assessing Competence in Intercultural Interaction;

4. Developing Competence in Intercultural Interaction;

5. Confronting Disadvantage and Domination in Intercultural Interaction; 
6. Adapting to Unfamiliar Cultures;

7. National Character: Being British;

8. National Character: Being American;

9. Achieving Understanding in Intercultural Interaction;

10. Promoting Rapport in Intercultural Interaction;

11. Intercultural Interaction and Cognitive Linguistics;

12. Translation as Intercultural Communication.

Целями освоения дисциплины «Практикум по межкультурной коммуникации» являются:

- Формирование, развитие и усовершенствование специальных компетенций в сфере межкультурной коммуникации.

- Знакомство с основами профессиональной коммуникации в различных сферах (менеджмент, сферы политики, бизнеса, науки).

- Овладение методами дискурсивного анализа иноязычного текста с учетом специфики лингвистических, национально-культурологических, прагматических, коммуникативных характеристик.

- Овладение методикой продуцирования иноязычных устных и письменных публицистических, деловых, научных текстов, предназначенных для использования в области межкультурной коммуникации.

- Формирование навыков по подготовке, организации и ведению бесед, переговоров, дискуссий. Подготовка сообщений, интервью в сфере межкультурной коммуникации.

- Формирование навыков подготовки и анализу кейсов в сфере межкультурной коммуникации.

Задачами освоения дисциплины «Практикум по межкультурной коммуникации» являются:

- обеспечение межкультурного общения в различных профессиональных сферах;

- выполнение функций посредника в сфере межкультурной коммуникации;

- выявление и критический анализ конкретных проблем межкультурной коммуникации, влияющих на эффективность межкультурных и межъязыковых контактов;

- обработка русскоязычных и иноязычных текстов в производственнопрактических целях;

- экспертный лингвистический анализ звучащей речи и письменных текстов на любом языке в производственно-практических целях;

- проведение эмпирических исследований проблемных ситуаций и диссонансов в сфере межкультурной коммуникации;

- организация деловых переговоров, конференций, симпозиумов, семинаров с использованием нескольких рабочих языков;

- применение тактик разрешения конфликтных ситуаций в сфере межкультурной коммуникации;

Работа по этому курсу ведётся с использованием новейших зарубежных разработок по темам курса. Система поддержки самостоятельной работы сту- 
дентов даёт студентам доступ ко всем необходимым материалам, которые преподаватель рекомендует как основные и дополнительные источники.

В рамках прохождения дисциплины «Практикум по межкультурной коммуникации» предусмотрено использование в учебном процессе следующих активных и интерактивных форм проведения занятий:

1) Ролевые игры, проведение бесед и дискуссий, дружеских приемов, споров, интервью.

2) Тренинги: по межкультурным конфликтам и способам их разрешения; тренинги по развитию межкультурной компетенции.

3) Представление презентаций, выступлений, сообщений, докладов.

4) Анализ (разбор) кейсов или коммуникативных событий.

5) Проектная деятельность.

В процессе освоения материала предполагается подготовка и защита проектных работ по ключевым разделам курса. Разработка проектов осуществляется как по группам, так и в индивидуальном порядке. Разработка проектов осуществляется в формате «мозгового штурма».

Обучение проводится в специально оборудованном компьютерном классе (рассчитанном на 15 студентов), выполняющем функции мультимедийного лингафонного кабинета.

Результаты учебной деятельности - отчёты, презентации, и т.д. - также выкладываются в системе Moodle. Там же студенты проходят необходимые тесты по предмету, которые проверяются автоматически. Поскольку система позволяет задавать сроки выполнения работ, использование тестов очень удобно для преподавателя.

Необходимо также отметить, что в последние годы большую популярность в мире приобрели Массовые Открытые Онлайн Курсы (MOOCs), основная цель которых - сделать образование доступным. Использование материалов подобных курсов на занятиях или прохождение какого-либо курса по межкультурной коммуникации как часть программы представятся нам целесообразным. Студенты получают доступ к дополнительным источникам информации, а также возможность общаться, принимать участие в обсуждениях на форумах, использовать знания и умения в межкультурной коммуникации на практике.

В целом, использование инновационных и информационных технологий при обучении студентов вузов межкультурной коммуникации представляется нам необходимым. Современная высшая школа, призванная выпускать специалистов высокого уровня, не может обойтись без использования данных технологий, а межкультурная коммуникация является тем учебным предметом, для которого использование инновационных и информационных технологий важно вдвойне.

\section{Список литературы:}

1. Волкова Е.В. Возможности получения дистанционного образования на проекте Coursera // Дистанционное обучение в высшем профессиональном образовании. СПб.: СПбГУП, 2014. С. 38-40. 2. Волкова Е.В. Основы теории межкультурной коммуникации: учебно-методический комплекс. ФГУП НТЦ «ИНФОРМРЕГИСТР». 
3. Депозитарий электронных изданий, регистрационное свидетельство № 35000 от 28 июля 2014 г., номер государственной регистрации 0321400470.

4. Концепция Федеральной целевой программы развития образования на 2011-2015 годы

(утв. распоряжением Правительства РФ от 7 февраля 2011 г. № 163-p).

URL: http://www.garant.ru/products/ipo/prime/doc/55070647/

5. Леонтович О.А. Методы коммуникативных исследований. М., 2011.

6. Федеральная целевая программа развития образования на 2011-2015 годы.

URL: http://fip.kpmo.ru/fip/info/13430.html

\section{References:}

1. Volkova E.V. Alternatives for Distant Education on Coursera Platform // Distant Learning in Higher Professional Education. St Petersburg, SPUHSC, 2014. Pp. 38-40.

2. Volkova E.V. Basis of Intercultural Communication Theory: Learning Pack. INFORMREGISTR.

3. Depositaries of electronic publications, certificate № 35000 of 28th July, 2014, state registration number 0321400470.

4. Concept of Federal Targeted Programme of Education Development for 2011-2015 years (order of the Government of the Russian Federation of 7th February, 2011. № 163-p).

URL: http://www.garant.ru/products/ipo/prime/doc/55070647/

5. Leontovich O.A. Methods of Communicative Research. M., 2011.

6. Federal Targeted Programme of Education Development for 2011-2015 years.

URL: http://fip.kpmo.ru/fip/info/13430.html

(C) 2014, Волкова Е.B.

Использование современных информационных и инновационных технологий при обучении студентов теории и практике межкультурной коммуникации
(C) 2014, Volkova E.V.

Use of modern information and innovative technologies while teaching theory and practice of intercultural communication to university students 
DOI: $10.17117 /$ no.2014.01.072

Поступило в редакцию: 27.11.2014

rector@kubsu.ru

\title{
Карпова А.Ю., Марченко М.Н. Дизайн фирменного стиля молодежных центров Российской Федерации
}

\author{
Karpova A.Yu., Marchenko M.N. \\ Corporate identity design of youth \\ centers in the Russian Federation
}

\begin{abstract}
В данной статье выявлены проблемы и обоснована необходимость создания фирменного стиля для молодежных организаций России. На основе проведенного исследования автором предлагается использовать опыт разработанного дизайнпроекта фирменного стиля Кореновского молодежного центра
\end{abstract}

Ключевые слова: фирменный стиль, молодежные центры, будущее молодежи, дизайн-проект,

Кореновский молодежный центр,

профессиональная подготовка будущих дизайнеров

\section{Карпова Анастасия Юрьевна}

Магистрант

Кубанский государственный университет

г. Краснодар, ул. Ставропольская, 149

\section{Марченко Марина Николаевна}

Доктор педагогических наук, профессор, зав. кафедрой

Кубанский государственный университет г. Краснодар, ул. Ставропольская, 149
In this article the problem and the necessity of creating a corporate identity for youth organizations in Russia are discussed. The results of the research made show that the developed design project of corporate identity of Korenovsky youth center can be employed by students, who study graphic design

Key words: corporate identity, youth centers, the future of young people, design project, Korenovsky Youth Center, vocational training of future designers

\author{
Karpova Anastasia Yurievna \\ Undergraduate \\ Kuban State University \\ Krasnodar, Stavropolskaya St., 149
}

\author{
Marchenko Marina Nikolaevna \\ Doctor of of Pedagogic Sciences, Professor, head of \\ department \\ Kuban State University \\ Krasnodar, Stavropolskaya St., 149
}

На данный момент в России существует достаточно большое количество молодежных центров. Практически в каждом субъекте Российской Федерации осуществляется молодежная политика в соответствии с постановлениями Правительства. Для чего же создаются молодежные центры и какую роль они играют в нашей стране?

Молодежь - будущее нашей страны. От того, насколько нравственной она будет, насколько высок будет уровень культурного наследия, создаваемый ею - настолько будет успешным развитие нашего государства по сравнению с другими странами мира. По сути, именно молодежь формирует нашу страну, является главной движущей силой. Даже от того, насколько молодые люди будут политически грамотными, каким лидерам власти будут отдавать предпо- 
чтение, зависит продвижение нашего государства по пути демократических преобразований, а также безопасность страны в целом.

В нашей стране необходимо привлекать молодых дизайнеров к созданию целостного образа каждого молодежного центра. Почему это так важно? Качественно разработанный фирменный стиль молодежных центров повлияет не только на рост притока молодежи, но и будет формировать имидж России. Оригинальный и запоминающийся образ организации сможет отразить необходимые преимущества, а также создать систему сквозной идентификации всех коммуникаций и проектов молодежных движений.

Решение подобных задач поможет формировать у молодых дизайнеров проектное мышление. Глубокое изучение проблемы позволит выработать комплексный подход к созданию фирменного стиля. Молодое поколение будущих дизайнеров в вузе сможет реализовать свои творческие возможности, а также проявить чувство патриотизма по отношению к России.

Созданию фирменного стиля молодежной организации способствует проведение предпроектного анализа. Для формирования средствами дизайна эффективного имиджа следует выявить цели, задачи, функции, особенности молодежных центров.

Сложившаяся на сегодня ситуация в сфере развития молодого поколения неоднозначна. С одной стороны, современную российскую молодежь отличает самостоятельность, практичность и мобильность, ответственность за свою судьбу, повышенная заинтересованность в получении качественного образования и профессиональной подготовки, влияющей на дальнейшее трудоустройство и карьеру. С другой стороны, молодым людям присущ низкий уровень интереса и участия в событиях политической, экономической и культурной жизни [1].

В Российской Федерации высок уровень безработицы среди молодых людей в возрасте 15-ти - 24-х лет $(6,4$ \%). В связи со стремительным старением населения и неблагоприятными демографическими тенденциями сегодняшние 10-ти - 25-тилетние жители страны станут основным трудовым ресурсом России, а их трудовая деятельность - источником средств, необходимых для социального обеспечения детей, инвалидов и старшего поколения.

Таким образом, существование нашего государства ложится на плечи каждого из последующих молодых поколений. Нельзя забывать не только об образовательном уровне, но и о нравственном воспитании молодежи. Именно для этого и нужны молодежные центры.

На сегодняшний день молодежные центры - это площадки поддержки молодежных инициатив, формирования и развития молодежных объединений, центры разработки новых методик организации работы с молодежью. Данные центры помогают молодежи правильно организовать свой досуг и самоутвердиться на этапе становления взрослым человеком, гражданином своей страны. Для того чтобы молодежь росла здоровой и высоконравственной, не имела таких зловредных пристрастий, как наркотики, алкоголь и курение, не обладала жестокостью и насилием, необходимо направлять ее в правильное русло, создавать все условия для ее заинтересованности в каждой сфере нашего госу- 
дарства. Необходимо также осуществлять поддержку молодых семей, понижать уровень безработицы, повышая тем самым коэффициент счастья в нашей стране.

Молодежные центры осуществляют государственную молодежную политику. Государственная молодежная политика - это система государственных приоритетов и мер, направленных на создание условий и возможностей для успешной социализации и эффективной самореализации молодежи, для развития ее потенциала в интересах России и, следовательно, на социальноэкономическое и культурное развитие страны, обеспечение ее конкурентоспособности и укрепление национальной безопасности [5].

Основными целями молодежной политики молодежных центров являются:

- содействие нравственному, интеллектуальному и физическому развитию молодых граждан;

- создание благоприятных, социальных, организационно-правовых условий для участия молодых граждан в системе общественных отношений;

- помощь молодым гражданам в решении социальных проблем;

- профилактика негативных проявлений в молодежной среде;

- воспитание молодых граждан в духе патриотизма, уважения к другим народам, к родному краю;

- творческое развитие молодежи;

- взаимодействие с молодежными объединениями;

- социальная поддержка молодых граждан.

Основными задачами являются:

- определение приоритетных направлений молодежной политики, на основе изучения молодежных проблем, а также мер по их реализации;

- обеспечение поддержки молодых семей в соответствии с действующим законодательством;

- формирование в поселениях условий для гражданского становления, патриотического и духовно-нравственного воспитания молодежи;

- обеспечение социальной адаптации молодых граждан, оказавшихся в сложной жизненной ситуации;

- оказание содействия в трудоустройстве и занятости молодых граждан;

- создание условий для интеллектуального, творческого и физического развития молодых граждан;

- поддержка общественно-полезной деятельности молодежи, молодежных и детских общественных объединений;

- информационное обеспечение для проведений межпоселенческой молодежной политики.

Таким образом, основополагающей задачей в реализации молодежной политики на территории Российской Федерации на современном этапе является создание благоприятных экономических, социальных, организационноправовых условий для воспитания, обучения и развития молодых граждан; проведение эффективной государственной молодежной политики, как одного 
из важнейших инструментов развития, роста благосостояния ее граждан и совершенствования общественных отношений [4].

Для выполнения таких серьезных целей и задач, составляющих молодежную политику, работа молодежных центров должна быть слажена по всем направлениям. Таким образом, каждый молодежный центр нуждается в собственном фирменном стиле. Какие он даст преимущества?

Молодежные центры повысят свою известность, смогут легче взаимодействовать с молодым поколением посредством понятного ему графического языка. Первое, визуальное знакомство молодежи и их родителей с графическим образом молодежной организации поможет получить доверие и признание в качестве особо значимого центра в поддержке и последующей реализации стремлений молодых людей.

В качестве примера рассмотрим ситуацию разработки фирменного стиля для Кореновского молодежного центра. Деятельность молодежного центра направлена на взаимодействие со всеми возрастными группами молодежи не только на территории Кореновского района, но и во всех его поселениях. Такая организация достойна внимания и известности не только на региональном, но и на всероссийском уровне. Исходя из вышесказанного, работа данной организации должна быть слажена по всем направлениям - от визуального и смыслового образа предприятия до его внутренней работы. Таким образом, возникает необходимость наличия фирменного стиля, ведь такая серьезная молодежная организация непременно должна обладать индивидуальным визуальным образом.

В результате предпроектного исследования установлено, что молодежный центр использует некоторые несвязанные графические приемы и элементы. Это может проявляться в дизайне футболок, например, футболки «Будущее - это мы» или праздничные, такие как «День семьи, любви и верности». В этом видится один большой недостаток - отсутствие единого стиля - нет ясности, что эти элементы указывают на Кореновский молодежный центр (рис. 1).

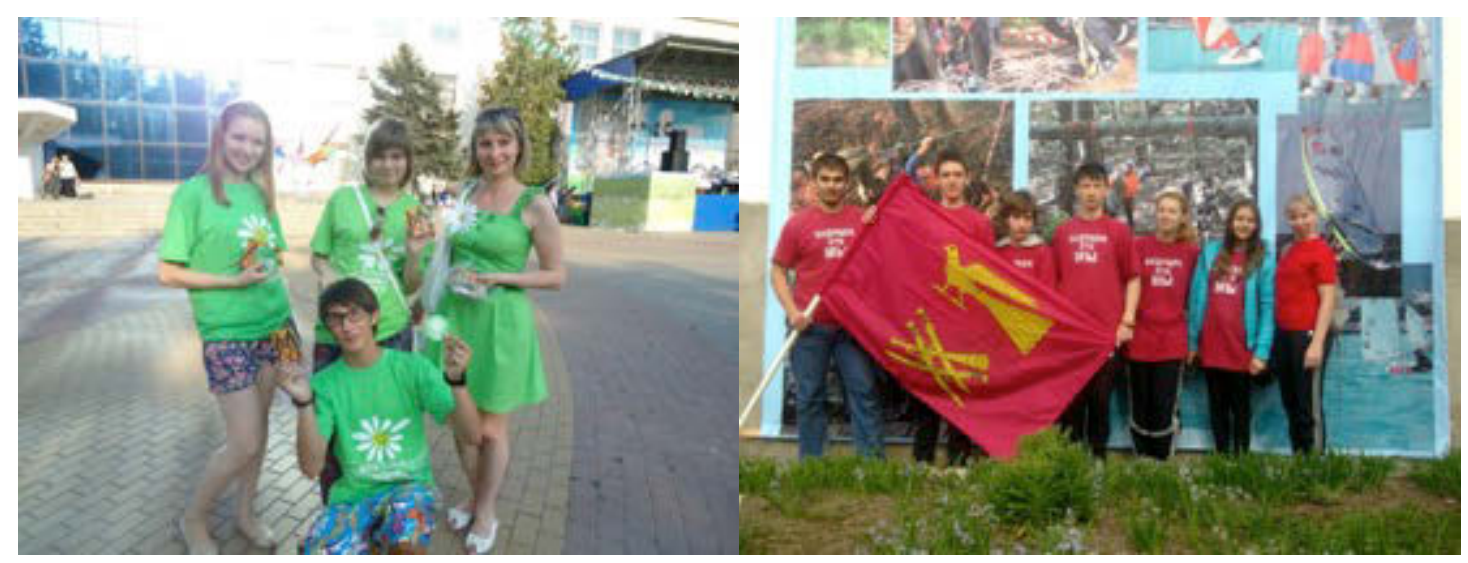

Рис. 1. Разнородность графического оформления

Таким образом, графическое изображение флага Кореновского района является единственным идентифицирующим элементом молодежного центра (рис. 2). Данная графика, безусловно, заключает в себе дух патриотизма и ува- 
жение к своей Родине, однако молодежной ее назвать нельзя. Наличие такой графики носит больше официальный характер, показывая серьезность молодежной организации, а также ее принадлежность к своему району. Исходя из этого, возникает необходимость создания графического языка, который будет отражать неповторимость Кореновского молодежного центра и иметь молодежный характер.
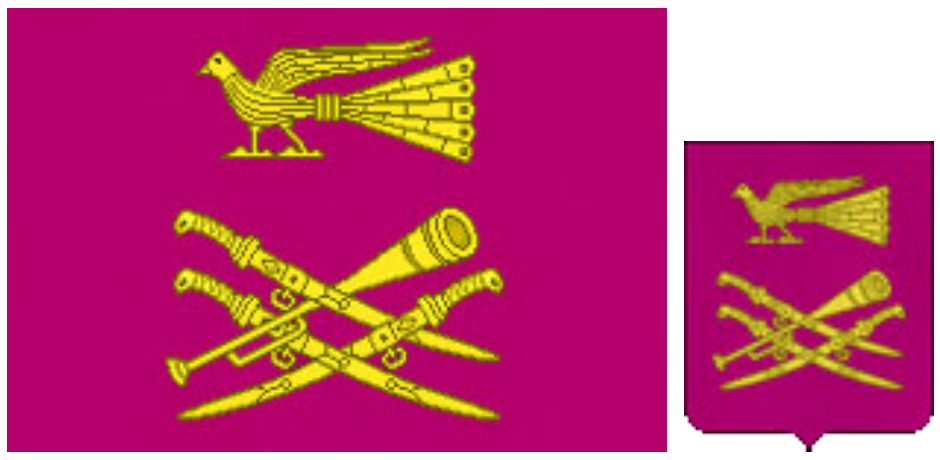

Рис. 2. Флаг и герб Кореновского района

После изучения и анализа аналогов конкурирующих предприятий, осуществляющих молодежну политику в России, проведен эксперемент участия в организованном молодежном шествии. Данный эксперимент помог обозначить некоторые аспекты в отношении дизайн-проектирования фирменного стиля молодежной организации.

1. Целостность. Для молодежной организации крайне важно, чтобы идентификация (как смысловая, так и внешняя) проходила не на уровне одного человека, а охватывала весь состав участников молодежного центра. Например, если бы по улице двигался человек в фирменной футболке и кепке, то мало кто из прохожил обратил бы на него внимание. И совсем другое дело, когда по улице движется целая группа молодых людей и все «как на подбор»- единая форма, единая символика - и характер молодежной организации приобретает уже совершенно другой масштаб. Такая цельная и внешне организованная группа уже не останется без внимания окружающих. Ведь в массовой целостности, объединенности одной идеей и образом состоит преимущество молодежной организации.

2. Оформление. На примере двух вузов - Кубанского государственного Университета и Кубанского Социально-Экономического Института - можно отметить, что на массовых мероприятиях более презентабильно выглядят представители первого вуза. Яркий оранжевый цвет футболок оригинален и заметен в городской среде в отличие от холодного синего цвета. Таким образом, внешнее оформление является особенно важным фактором конкурентоспособности с другими организациями (рис. 3). 


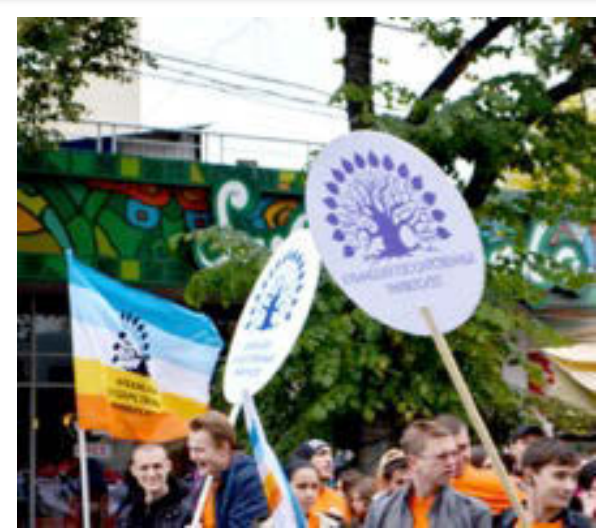

Рис. 3. Оформление молодежного шествия

3. Фирменная символика. Наличие фирменной символики играет огромную роль. Носители фирменной символики, такие как флаги и различные держатели с эмблемой, являются важнейшими атрибутами молодежных шествий и мероприятий (рис. 4). Важным фактором служит запоминаемость молодежной организации и ее идентификация на фоне остальных предприятий, проводящих молодежную политику.

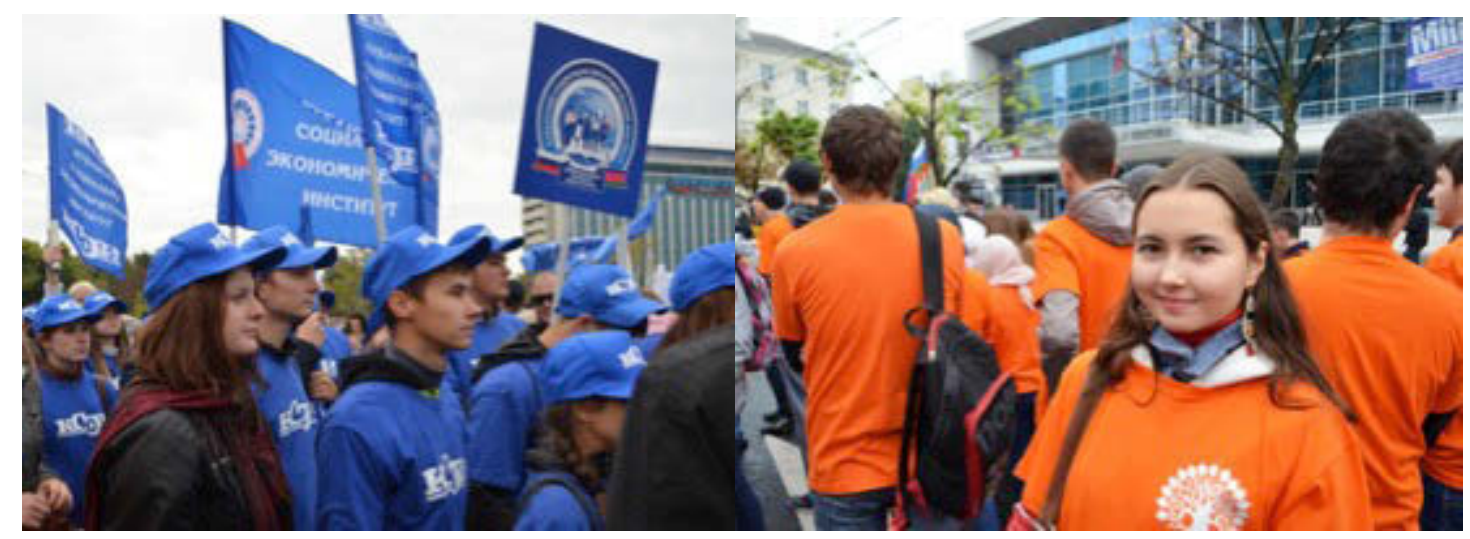

Рис. 4. Фирменная символика

Необходимо более четко и ясно осветить все проблемы, выявленные в результате анализа предпроектной ситуации исследуемого объекта - Кореновского молодежного центра.

1. Молодежный центр не обладает внешними идентификационными особенностями на фоне других молодежных организаций страны. Ему необходимо обладать большей известностью, как на региональном, так и на всероссийском уровне. Это касается и целевой аудитории (молодежи), которую необходимо привлекать в молодежный центр, и окружающих, которых нужно информировать о существовании центра и о его деятельности.

2. Кореновский молодежный центр не обладает собственным фирменным стилем. Организация имеет некоторый графический образ, но он характеризуется разрозненностью и отсутствием цельности. Молодежный центр использует некоторые несвязанные графические приемы и элементы. Из-за отсутствия единого стиля нет ясности, что эти элементы указывают на Кореновский молодежный центр. 
3. Отмечено отсутствие графического языка, отражающего молодежный характер организации. Для осуществления молодежной политики, реализации целей и задач Кореновского молодежного центра необходим графический язык, который будет понятен и интересен целевой аудитории, а так же сможет способствовать успешному взаимодействию с ней.

4. Обнаружено отсутствие системы навигации на местности, где Кореновский молодежный центр осуществляет свою деятельность. Для налаживания системы ориентирования на территории проведения молодежной политики необходимы носители информации, указатели с соответствующими пиктограммами и др.

5. Отмечено отсутствие наружной рекламы, информирующей о деятельности молодежного центра, а также о предстоящих мероприятиях данной организации, о которых должны знать все жители Кореновского района. Наоборот, обо всех важных событиях осведомлены только участники Кореновского молодежного центра, которые могут обмениваться новостями в социальных сетях. Но интернет-ресурсы доступны не всем, и поэтому очень важно, чтобы наружная реклама была предусмотрена на всей территории деятельности центра.

6. Отсутствует оформление концертной сцены. Концертная сцена города Кореновска, расположенная снаружи, возле Кореновского районного центра народной культуры и досуга, обладает достаточно скупым оформлением во время проведения мероприятий молодежного центра.

Для создания графического образа Кореновского молодежного центра были определены некоторые критерии. Первый из них - это ряд ассоциативных определений, которые должны характеризовать фирменный стиль данной организации:

- цельность;

- пластичность;

- активность;

- креативность;

- привлекательность;

- конкурентоспособность;

- удобство использования;

- долговечность.

Второй, не менее важный критерий, заключается в том, что подача графических элементов фирменного стиля должна быть общепонятной и легко воспринимаемой.

И, наконец, третий критерий выражает собой необходимость создания графического языка, носящего молодежный характер. Именно поэтому был проведен ряд определений, ассоциирующихся с молодежью:

- активность;

- целеустремленность;

- гибкость;

- вдохновенность;

- успешность; 
- свобода.

Этап формирования образа молодежной организации - это трудоемкий, а порой даже длительный процесс, сопровождающийся продуцированием идей и выполнением эскизов в рамках проектной задачи. Перед тем, как прийти к итоговому образу, полностью соответствующему поставленным требованиям, необходимо проделать большую работу в поиске графических средств и решений.

Учитывая определенные в процессе проектирования фирменного стиля критерии создания графического образа, было найдено шрифтовое начертание, пластический язык которого отражает молодежный характер центра (рис. 5).

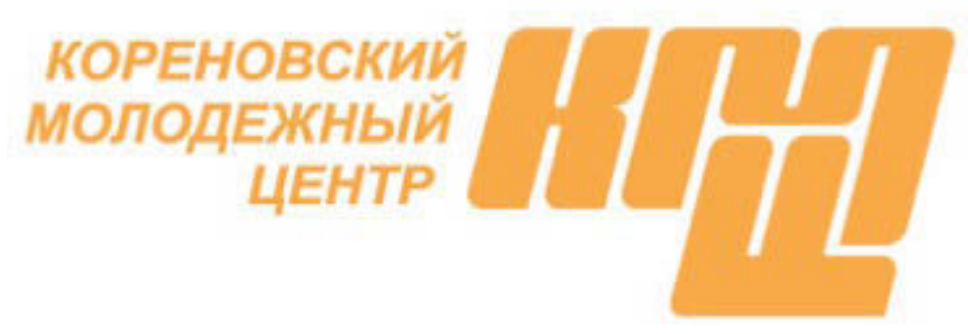

Puс. 5-Шрифтовое начертание
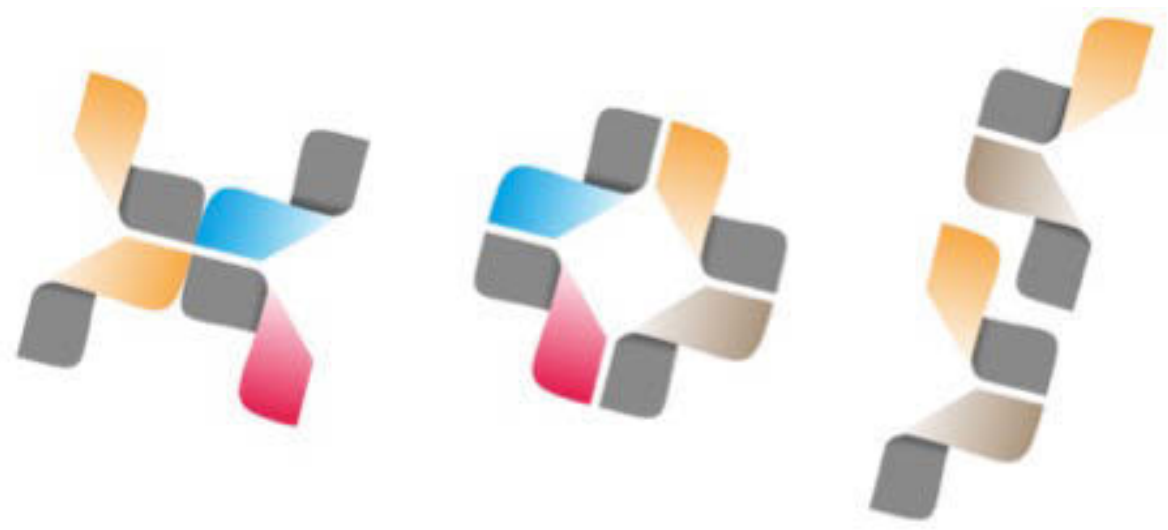

Фирменная графика в результате поисков приобрела необходимые форму и цвет. Наиболее важный момент заключался в модульной системе, которая объединила собой и шрифтовое начертание, и графические элементы. Благодаря разработанному модулю, фирменная графика стала вариативной и динамичной, системы сочетающихся друг с другом элементов получили возможность приобретать различные формы.

Разработанная графика в какой-то степени является инфографикой. Но она служит больше средством привлечения внимания к фотографиям, чем к наборному тексту. Таким образом, складывается логическая цепочка - человек вначале обращает внимание на графическое изображение и, заинтересовавшись, начинает читать к нему текст.

Немаловажным является и то, что разработанные графические элементы призваны привлекать внимание к шрифтовому начертанию. Это способствует узнаваемости молодежной организации через восприятие визуальных графических констант. 
Таким образом, графические элементы, основанные на вариативности модуля, создают интересные для молодежи изобразительные композиции. Текстура построена на "иконичности" шрифтового начертания, а пурпурный цвет, объединяющий компоненты дизайн-проекта, созвучен геральдике Кореновского района. Все элементы фирменного стиля создают единый неповторимый образ Кореновского молодежного центра.

Были изучены принципы проектирования, требования, предъявляемые к дизайну фирменного стиля, его структура и др. Произведен анализ аналогов, в ходе которого выявлены некоторые особенности, помогшие в создании данного дизайн-проекта. Так же осуществлен подбор изображений, цветовой гаммы и шрифта.

В результате проведенного исследования выявлены некоторые особенности проектирования фирменного стиля, использованные в создании образа молодежного центра.

В результате проделанной работы была достигнута цель и выполнены поставленные проектные задачи, а именно:

- определен графический образ и сформулированы основные задачи фирменного стиля Кореновского молодежного центра;

- собран материала и проведен анализ существующих графических образов молодежных организаций России;

- создана общая концепция дизайн-проекта;

- разработан фирменный стиль Кореновского молодежного центра - основные константы, носители, удовлетворяющие потребности целевой аудитории.

Решение данной задачи включало следующие этапы:

- определены элементы и носители фирменного стиля Кореновского молодежного центра;

- подобраны цветовая гамма и шрифты;

- определен графический язык, ориентированный на молодежь, удовлетворяющий вкусам и эстетике данной целевой аудитории, а так же понятный всем;

- разработана полиграфическая продукция, способная максимально емко и точно доносить информацию, предоставляемую молодежным центром;

- разработано оформление презентации и концертной сцены с использованием средств трехмерной компьютерной визуализации.

Все элементы фирменного стиля составляют целостную структуру, что создает гармоничное впечатление при визуальном контакте целевой аудитории с фирменной рекламной продукцией данной организации.

Фирменный стиль отвечает всем заданным требованиям, таким образом, он является:

- целостным, поскольку все элементы выдержаны в едином стиле;

- конкурентоспособным;

- ярким и запоминающимся;

- понятным;

- направленным на успешное развитие организации. 
Было проведено исследование, в результате которого опрошенные отметили, что фирменный стиль удался, отвечает поставленным задачам и соответствует концепции. Таким образом, результатом проделанной работы стала реализация фирменного стиля Кореновского молодежного центра в жизнь в 2014 году.

Важно отметить, что данный опыт может быть использован в дальнейшем молодыми дизайнерами в процессе дизайн-проектирования фирменного стиля любой молодежной организации России. Реализация проекта в полной мере оправдала необходимость создания индивидуального образа Кореновского молодежного центра.

\section{Список литературы:}

1. Агранович М.Л. Положение молодежи в России. М.: Машмир, 2005. С. 3.

2. Ажгихин С.Г. Создание проектного образа в процессе разработки рекламных изображений // Преподаватель ХХІ век. 2009. № 3-1. С. 187-192.

3. Марченко М.Н. Графическая деятельность и компьютерные технологии в профессиональной подготовке будущих дизайнеров // Историческая и социально-образовательная мысль. 2013. № 5 (21). C. $115-118$.

4. Постановление об утверждении ведомственной целевой программы Молодежь Кореновского района на 2014 год. Кореновск, 2013. № 2046.

5. Стратегия государственной молодежной политики в Российской Федерации. М., 2006. № 1760-р.

\section{References:}

1. Agranovich M.L. Youth Development in Russia. Analytical Report. M.: Mashmir, 2005. P. 3.

2. Azhgihin S.G. Creation of a design image during development of advertising images // Prepodavatel XXI. M., 2009. № 3-1. Pp. 187-192.

3. Marchenko M.N. Graphical activities and computer technologies in the professional training of future designers // Historical and socio-educational thought. 2013. № 5 (21). Pp. 115-118.

4. Decision on approval of the departmental target program Youth Korenovsky area in 2014. Korenovsk, 2013. № 2046.

5. Strategy of the state youth policy in the Russian Federation. M., 2006. № 1760-p.

(C) 2014, Карпова А.Ю., Марченко М.Н.

Дизайн фирменного стиля молодежных центров

Российской Федерации
(C) 2014, Karpova A.Yu., Marchenko M.N. Corporate identity design of youth centers in the Russian Federation 
DOI: $10.17117 /$ no.2014.01.082

Поступило в редакцию: 16.11.2014

rector@kubsu.ru

\title{
Марченко М.Н., Ивашечкина Е.А. Дизайн фирменного стиля компаний, специализирующихся на геолого-геофизических
}

изысканиях

\author{
Marchenko M.N., Ivashechkina E.A. \\ Corporate Identity design of companies specializing \\ in geological and geophysical explorations
}

В данной статье затронута проблема формирования имиджа компании, основанная на создании фирменного стиля. Авторы оправданно предлагают решение проблемы путем разработки полноценного фирменного стиля. Представленные в статье реализуемые проектные принципы показывают оптимальный вариант решения идентификации компании посредством фирменного стиля. Так же, представленные в статье принципы, используемые в проектирование фирменного стиля, применяются и в педагогической деятельности. Что позволяет повысить уровень знаний и качество проектов у студентов

Ключевые слова: графический дизайн, фирменный стиль, дизайн, композиция, графический элемент, шрифтовой блок, знак, педагогика, обучение, наука, развитие, модернизация образования

\section{Марченко Марина Николаевна}

доктор педагогических наук, профессор,

зав. кафедрой

Кубанский государственный университет

2. Краснодар, ул. Ставропольская, 149

\section{Ивашечкина Елена Анатольевна \\ Магистрант \\ Кубанский государственный университет 2. Краснодар, ул. Ставропольская, 149}

This article deals with the problem offorming the image of the company based on the creation of corporate identity. The authors propose a solution of this problem by means of the development of highgrade corporate identity. The design principles presented in the article show the optimal solution by identifying the company's corporate identity. The principles presented in the article and used in the design of corporate identity are also employed in teaching, which can increase the level of knowledge and quality of the projects of students

Key words: graphic design, corporate identity, design, composition, drawing entity, graphic font unit, mark, pedagogy, education, science, development, modernization of education

\author{
Marchenko Marina Nikolaevna \\ Doctor of Pedagogic Sciences, Professor, \\ head of Department \\ Kuban State University \\ Krasnodar, Stavropolskaya St., 149
}

\author{
Ivashechkina Elena Anatolievna \\ Undergraduate \\ Kuban State University \\ Krasnodar, Stavropolskaya St., 149
}

Формирование своего фирменного стиля является первым шагом на пути создания сильного имиджа компании. В большинстве случаев, с ней и ее продуктом потребитель знакомится именно благодаря фирменному стилю. Фирменный стиль - это набор единых принципов оформления, цветовых сочетаний и образов для всех форм рекламы, деловых бумаг, документации, упаков- 
ки, офиса и даже одежды сотрудников. Традиционно к фирменному стилю принято относить такие элементы, как фирменный знак, логотип, фирменный символ, фирменный блок, фирменные цвета, фирменный шрифт, фирменные производственные материалы, слоган, фирменная документация, торговая документация, упаковка, наружная реклама [2].

«Комплектация» фирменного стиля напрямую зависит от сферы деятельности, рекламной активности, целей компании, лояльности потребителя к товару или услуге и от прочих факторов. Однако все эти элементы теряют какой-либо смысл, если не подчинены одной идеологической составляющей, не работают на создание одного имиджа.

Также, наряду с идеологией, которая должна быть вложена в фирменный стиль, он должен отвечать ожиданиям целевой аудитории, «подыгрывать» ее представлениям о товаре или услуге. Опыт показывает, что многие клиенты, заказывая разработку фирменного стиля, в обязательном порядке указывают в брифе два ключевых слова: «дорого» и «солидно». На самом деле, фирменный стиль должен подчеркивать характер организации, акцентировать внимание потребителя на ее сфере деятельности [9].

Все элементы фирменного стиля составляют одну целостную композицию, создающую жизнеспособное представление о компании. Благодаря этому, у потребителей рождается целостный и позитивный образ работы предприятия. В эпоху информационной лавины, когда потребителю приходится ориентироваться среди пестрящего разнообразия идентичных товаров, актуальность наличия фирменного стиля только повышается [8]. Фирменный стиль нужен для того, чтобы посредством единства и индивидуальности графических и других констант, выделиться среди конкурентов, стать узнаваемым и хорошо запоминаемым для потребителя. Чем быстрее начнут узнавать компанию, тем быстрее начнут сотрудничать с ней. Высокая узнаваемость уменьшает количество средств, потраченных на рекламные кампании. Наличие хорошо продуманного фирменного стиля значительно повышает эффективность рекламы [2].

Особенности фирменного стиля определяют ориентиры развития компании, помогают сформировать корпоративный этикет. С помощью фирменного стиля можно моделировать мнение о компании, направить мнение потребителя о ней в нужное русло. Также четкий фирменный стиль помогает сотрудникам представлять компанию на потребительском рынке.

Когда целевая аудитория знает фирменный стиль, она с большей долей вероятности обратит внимание на привычные цвета, формы, шрифты, логотип, потому как в этом случае они становятся своеобразным «маячком» для потребителей: товар находится в зоне их интересов.

Как известно, человек быстрее всего запоминает объекты, которые максимально соответствуют его представлениям, отвечают требованиям, которые он им предъявляет. Если образ компании, созданный с помощью фирменного стиля, близок потребителю, уровень его лояльности будет расти с каждым новым контактом. А лояльность целевой аудитории в свою очередь способствует как минимум закреплению, а как максимум - росту уровня продаж компании [9]. 
При создании фирменного стиля не стоит забывать об идеологии компании.

Стиль можно тогда считать успешным, когда он передает суть компании, ее характер, ее ценности.

В России не все бизнесмены осознали необходимость внедрения корпоративной культуры на своих предприятиях, поэтому идеологию компании никто не сможет описать лучше, чем владелец бизнеса.

Вы как владелец бизнеса должны быть уверены в том, что графическое исполнение фирменного стиля действительно соответствует той идеологии, которая в него закладывалась [6].

Приведем пример компаний, занимающихся геолого-геофизическими изысканиями. На сегодняшний день фирм, занимающихся геологогеофизическими изысканиями очень много, но аналоговый материал представлен, главным образом, в виде товарного знака. В основном товарный знак показан графическим элементом со шрифтовым начертанием. Графический элемент представляет собой изображение земли как реалистично, так и стилизованно. Не смотря на то, что компаний в этой сфере очень много, ни одна из них не стремится выделить себя с помощью качественно проработанного фирменного стиля.

Так, например, в Краснодаре находится 34 компании, занимающихся инженерно-геофизическими и геолого-геофизическими изысканиями, но наиболее крупными являются: «СевКавТисиз», «ГеоОлимп», «ИнжГеоСервис», «Краснодарнефтегеофизика», «Кубань Изыскания», «ГеоЛад» и другие.

Для начала рассмотрим компанию «СевКавТисиз».

Компания существует на данном рынке услуг в течение 49 лет. ЗАО «СевКавТИСИЗ» выполняет широкий диапазон работ любой сложности в области изысканий для строительства и проектирования. Компания имеет неполноценный фирменный и у нее полностью отсутствует корпоративный набор, так необходимый в этой области услуг [8].

Компания в течение многих лет не уделяет своему фирменному стилю значительного внимания, она не проводит ребрендинг уже имеющихся элементов стиля и не стремится его доработать, вследствие чего снижается ее конкурентоспособность.

В набор элементов фирменного стиля компании СевКавТисиз входят: логотип, фирменные цвета, слоган, сайт. Рассмотрим каждый из элементов.

Проанализируем товарный знак, логотип ЗАО "СевКавТисиз»". По виду это изобразительный логотип, представляющий собой графическое изображение стилизованной планеты Земля. В целом данный логотип, обладая рядом достоинств (простота изображения, природная ассоциативность), все же обладает более значительными недостатками (он слишком дробен, не пропорционален, излишне детализирован). Немаловажно также цветовое оформление логотипа, несущее также эмоциональную окраску. Данный логотип изображается в сине-красном цвете (рис. 1).

Вследствие того, что красный цвет слишком агрессивен в сочетании с синим, он не дает ассоциации с надежностью фирмы. Таким образом, основные 
задачи, возлагаемые на логотип - обратить на себя внимание, понравиться, остаться в памяти - не достигнуты.

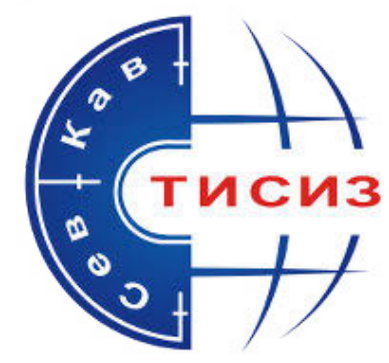

Рис. 1. Логотип компании "СевКавТисиз»

Фирменный слоган компании: "Вы сказали невозможно? Мы сделаем!". Этот слоган можно расценить неоднозначно, с одной стороны они позиционируют себя на рынке геологических услуг как самый выгодный партнер в этой сфере, а с другой стороны - не связанный с этой темой потребитель может подумать, что это компания, занимающаяся другим родом деятельности, не имеющая отношения к геологии.

Корпоративными цветами ЗАО "СевКавТисиз" является сочетание синего и красного цветов. Идея выбора данного цвета, на первый взгляд, правильна. Целевой аудиторией компании являются деловые люди: как раз для этой аудитории выбор данных цветов наиболее приемлем. Применение фирменных цветов предполагает их использование на всех носителях фирменного стиля. Но этого не происходит: фирменные цвета компании не выделяются и не несут никакой эмоциональной нагрузки.

В целом созданный фирменный стиль компании можно считать неэффективным элементом в формировании имиджа компании, так как ни один из имеющихся элементов не отвечает требованиям эффективного воздействия на потребителя.

Следующим аналогом в сфере геологических услуг является компания «Геолад». Диапазон услуг, предоставляемых компанией также высок, хотя, надо сказать, у предыдущего аналога спектр услуг был шире.

Компания на протяжении своего долгого пребывания на рынке не проводит никаких обновлений в своем графическом оформлении. С одной стороны, это положительное качество, т.к. в сознании потребителя за такой большой промежуток времени мог сложиться четкий образ этой компании. Однако дело в том, что потребитель развивается и меняется в данное время динамично.

В частности, оформление логотипа компании Геолад вызывает спорные чувства. Во-первых, такой прием как разрыв слов по центру - не самое удачное решение для компании, которая должна вызывать чувство надежности и уверенности. Во-вторых, эллипс, в который вписан сам логотип, имеет слишком вытянутую форму и кажется излишне деформированным, что опять-таки не формирует представления о надежности (рис. 2). 


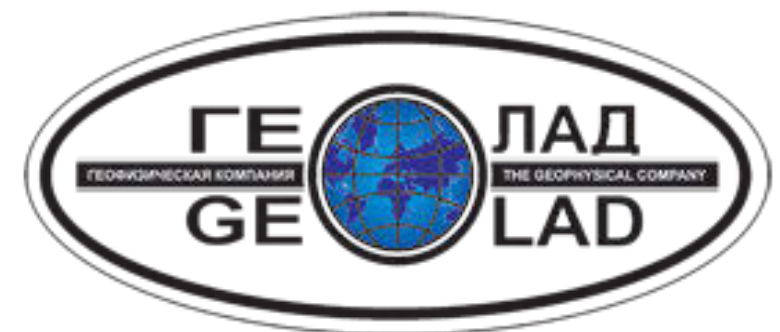

Рис. 2. Логотип компании «ГеоЛад»

Внутри данного эллипса проходит темная плашка со статусной строкой, выполненной в белом цвете. Не стоит также забывать, что данный логотип вмещает в себя два вида начертаний на латинице и кириллице. Вследствие этого получается некая путаница и не сразу понятно, откуда берет начало данный логотип и с какой стороны его продолжение. В целом он выглядит дробно как за счет своей нестандартной формы, так и за счет выбранных цветов.

Цвета, которые использованы для оформления, также не отличаются оригинальностью, как и во многих последующих аналогах использован голубой, синий и терракотовый. И если выбор терракотового цвета обоснован тем, что напрямую связан с неким образом земли, то голубые и синие цвета совершенно не имеют основания.

Далее стоит подробнее рассмотреть геодезическую компанию «Краснодарнефтегеофизика», старейшее предприятие, работающее на Кубани более 50-ти лет. Из-за неудобочитаемого длинного названия в логотипе написана лишь аббревиатура «КНГФ». Но, даже несмотря на это сокращение, название и довольно несозвучную аббревиатуру запомнить крайне сложно. Не способствует запоминанию также сложное и крайне неудобочитаемое начертание букв в логотипе. Они геометризированы, некоторые элементы букв разделены на модули, которые создают излишнюю дробность и совершенно не способствуют легкому прочтению данной аббревиатуры.

Нижняя часть логотипа представлена равносторонним треугольником, а одна из сторон разделена на те же модули, что и в логотипе. Также вызывает затруднение деление на зоны с помощью цвета. Верхняя и нижняя части за счет разных цветовых гамм просто разваливаются и не создают единства. Отсюда и сложности восприятия (рис.3).

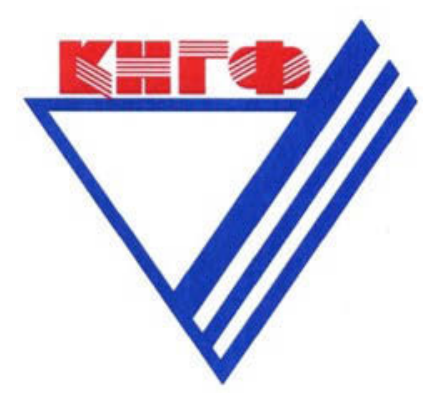

Рис. 3. Логотип компании «Краснодарнефтегеофизика»

Надо сказать, что у данной компании также нет полноценного фирменного стиля или корпоративного набора, следовательно, найти их можно лишь в 
интернете. Созданный компанией сайт - это, безусловно, немалый плюс, так как сейчас продуктивнее всего работать именно в сети Интернет (рис.4).

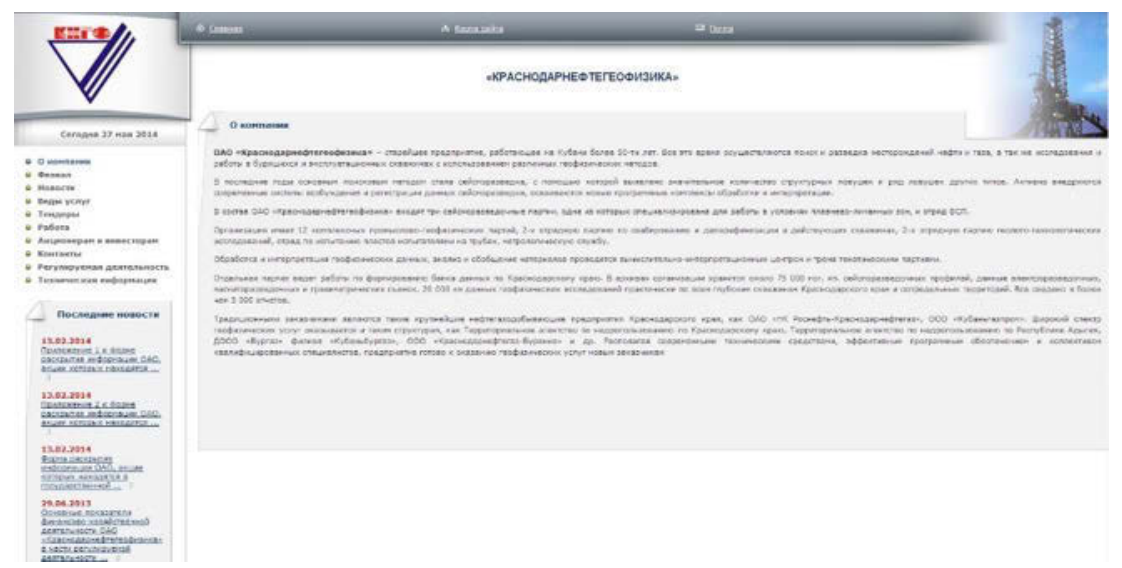

Puс. 4. Сайт компании «КНГФ»

Но, надо думать, что должны быть проведены и рекламные акции, а также, безусловно, для столь серьезной компании должен быть продуман корпоративный набор. Документация имеет очень значимую роль в жизни компании. А именно документация у данного представителя на рынке геологических услуг отсутствует.

Следующим примером является геодезическая компания «РостГеоСтрой». Компания занимается работами по всему краю и за его пределами [7]. У них присутствуют хотя бы задатки фирменного стиля, в отличие от их конкурентов. Есть некая графическая текстура, напрямую связанная с темой, знак и логотип. Логотип выполнен гротескным жирным шрифтом без засечек, каждая часть аббревиатуры написана с большой буквы, при прочтении это значительно облегчает восприятие. Также данная организация имеет свой знак, который слишком изобразителен и сложен. Он включает в себя объемный глобус, разделённый на меридианы и параллели, а также объемный циркуль сверху (рис. 5).

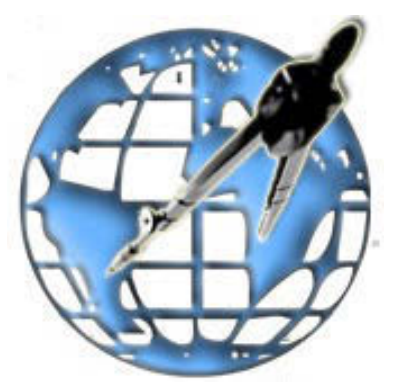

\section{Рис. 5. Знак компании «РостГеоСтрой»}

Надо сказать, что задумка довольно удачная - преподнести геодезию как точные измерения земли, ведь суть такова и есть. Недостатки данного знака не только в чрезмерной изобразительности, но и в том, что две части знака имеют совершенно разный графический язык. И это не дает потребителю воспринимать его как единое целое. Также за счет этого нюанса создается излишняя дробность. 
Следующим аналогом является компания «Кубань Изыскания». Данная компания также, как и вышеперечисленные компании, не имеет состоявшегося фирменного стиля, но имеет логотип, знак и отличную от своих предыдущих конкурентов цветовую гамму [4-3].

Логотип компании выполнен гротескным шрифтом без засечек, имеет широкие сближенные основные элементы, за счет сближенности элементов и получается довольно узкое начертание как в шрифте Impact. Знак довольно лаконичен и прост (рис. 6). Представляет собой круг со сквозными линейными прорезами. Кривые линии видимо показывают сложную многослойную структуру земли, а то, что он закомпонован в круг, символизирует планету в целом.

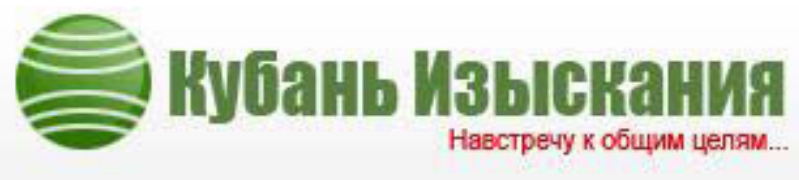

Рис. 6. Логотип компании

Надо сказать, что за счет своей круглой формы и линейным вставкам, а также зеленому цвету знак данной фирмы похож на знак всем известного «Сбербанка». Это неприемлемо, так как разные сферы деятельности и сближенные по стилистике и начертанию знаки создадут путаницу в подсознании потребителей и, конечно же, затруднят идентификацию данной фирмы.

Зеленый цвет данная организация выбрала по той причине, что сфера ее деятельности распространяется не только на геофизические изыскания, но и на экологию. А такой светлый и сочный зеленый цвет ассоциируется с молодой зеленью, чистотой и экологичностью.

Нельзя обойти вниманием и слоган компании, который написан контрастным красным к зеленому. Слоган звучит так: «Навстречу к общим целям». Такими словами данная организация призывает к сотрудничеству и говорит о том, что может помочь в достижении вашей цели. В отличие от предыдущих конкурирующих аналогов «Кубань Изыскания» не создает себе слоганом позиции самой наилучшей организации, в которую следует обратиться. Данная фирма предлагает вам сотрудничество и помощь за счет избавления от повелительного наклонения статусной строки. Потому что «самых лучших» много, а надежных и качественных единицы.

Все представленные выше действующие организации имеют практически одинаковые решения, которые очень далеки от современного представления о рынке геодезических услуг. Практически у всех отсутствует полноценный фирменный стиль, и даже корпоративный набор. За отсутствием фирменного стиля организации естественно не имеют нормальной полноценной рекламы, а зачастую пользуются лишь сарафанным радио или средствами сети Интернет, руководствуясь тем, что «нужные знают». На самом деле в данный момент на рынке услуг геолого-геофизических изысканий конкуренция между организациями высока и следует выделять себя не только кричащими фразами или красным цветом слоганов. Нужно иметь полноценный сложившийся 
образ компании, чтобы оставлять в сознании потребителя определенные ассоциации. Ведь графические элементы не только позволяют создать образ, но и могут рассказать о положительных качествах организации.

Также немаловажно наличие в данных организациях корпоративных наборов. Ведь все бумаги, высылаемые или передаваемые другим сотрудничающим лицам, должны иметь опознавательные знаки для завуалированной рекламы.

Покажем особенности дизайн-проектирования фирменного стиля на примере компании «ГЕОФИЗ». Новый имидж компании будет основан на правильном подходе к рекламированию компании и услуг.

На основе анализа фирменного стиля конкурирующих фирм было выявлено, что наиболее успешным и запоминающимся будет знак с использованием графического элемента и шрифтового начертания. Выбор цветового решения основывается на политике и философии компании. Таким образом, были выбраны белый, оттенки зеленого и черный цвет. Эти цвета полностью характеризуют компанию «ГЕОФИЗ», так как она молода, целеустремлена, умеет правильно общаться с клиентами и достигает поставленных целей. Фирменный стиль должен быть исполнен в минималистичном стиле с использованием фирменной символики.

Постоянство цветового сопровождения в носителях фирменного стиля работает на идентификацию и усиление общественного имиджа.

В процессе формирования концепции создания фирменного стиля компании «ГЕОФИЗ» была определена комбинированная форма знака, которая включает в себя графический элемент и шрифтовое начертание (рис.7).

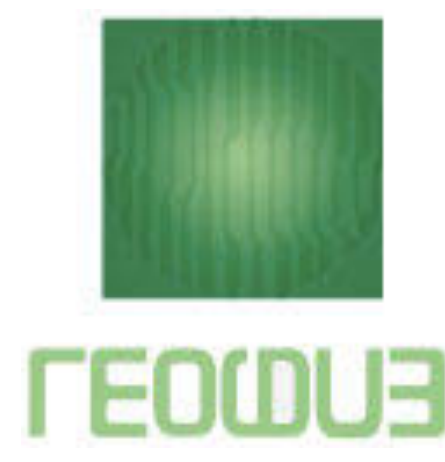

Рис. 7. Логотип компании «ГЕОФИЗ»

Элементы фирменного стиля компании «ГЕОФИЗ» разработаны в едином стиле.

Цвет является важнейшим элементом фирменного стиля. Он делает элементы фирменного стиля более привлекательным и запоминающимися. Основными фирменными цветами компании «ГЕОФИЗ» выбраны зеленый и белый, а также - градиент от темно-зеленого к белому, градиент от темнозеленого к светло-зеленому. Выбранные цвета выглядят контрастно и еще раз подчеркивают общую концепцию фирменного стиля.

Во всем фирменном стиле компании «ГЕОФИЗ» прослеживается цветовое взаимодействие. 
Исходя из политики компании и рода ее занятия, в качестве необходимой составляющей была разработана текстура, основанная на стилизации сейсмологических волн. Это было сделано для того, чтобы закрепить связь образа и названия в сознание потребителя. Сами графические элементы не навязчивы и довольно лаконичны (рис.8).

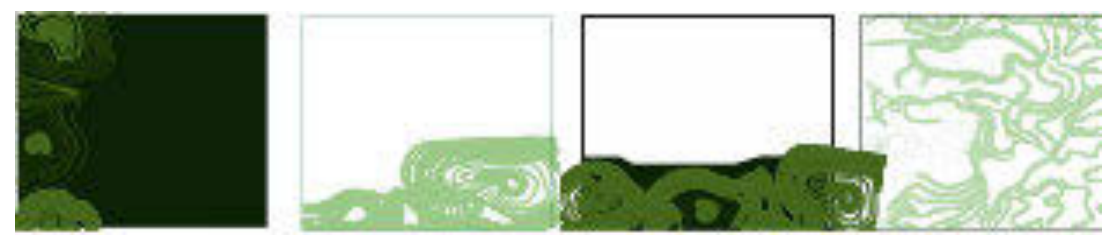

Рис. 8. Графический элемент

Комплект шрифтов вносит свой вклад в формирование фирменного стиля компании «ГЕОФИЗ». Для того чтобы придать еще большую индивидуальность и узнаваемость компании, ее услугам, был использован набор шрифта «Europe» и «Таһoma».

Для того чтобы осведомить целевую аудиторию в лице потенциальных клиентов и партнеров о появлении фирменного стиля компании, было решено провести распространение рекламной продукции (носителей фирменного стиля), созданной в процессе разработки фирменного стиля, вручить сувенирную продукцию.

С увеличением потока информации, поступающей, прежде всего, через различные электронные СМИ в наше время, когда товары на рынке становятся все более и более похожими, а предлагаемые услуги идентичными, предприятия, специализирующиеся на выпуске конкурентных продуктов, должны стремиться к тому, чтобы создать собственный положительный и уникальный имидж, как в обществе, так и среди своих конкурентов. Только таким образом можно не только обозначить свою уверенную позицию на рынке, но и укрепить и сохранить ее. Четкий и лаконичный образ, состоящий из довольно простых стилеобразующих элементов, выделяет компанию из числа других аналогичных проектов и занимает достойное место в ряду других.

В заключение стоит обратить особое внимание на то, что фирменный стиль - это инструмент «замедленного действия». Не стоит ждать от него немедленного эффекта. В зависимости от уровня рекламной активности должно пройти достаточно времени для того, чтобы фирменный стиль увидели, поняли, запомнили. И главное - не стоит забывать о том, что фирменный стиль это «графическое» лицо компании, которое «говорит» клиентам о том, что представляет собой данная компания.

Важно понимать, что начало работы компании - самое ответственное время, потому что в этот период закладывается ее имидж. Фирменный стиль, как неотъемлемый элемент образа компании проникает повсюду. По качеству оформления документов, дизайну логотипов, сайта и рекламных проспектов клиенты и партнеры будут судить о компании. Поэтому не рекомендуется экономить на качестве разработки фирменного стиля и средствах по его внедре- 
нию. Компания будет нести косвенные убытки, если у конкурентов будет более привлекательный фирменный стиль.

Процесс продвижения фирменного стиля - неотделим от формирования имиджа компании. Нельзя, однажды проведя успешную презентацию или заказав партию дорогих ручек и ежедневников, быть уверенным, что теперь имидж работает на компанию. Продвижение фирменного стиля - ежедневная и кропотливая работа, работа на имидж, которую нельзя отложить на потом.

Хорошей компании не нужно искать клиентов - клиенты сами ищут её. Логотип, визитки и фирменная продукция - это лицо компании. К разработке элементов фирменного стиля следует подходить со всей серьёзностью. От каждой детали зависит то, как воспринимает компанию потребитель. Главное - это единство стиля во всех компонентах. Дизайн фирменного стиля должен быть максимально эффективным.

Представленные в статье реализуемые проектные принципы, ориентированы на оптимальное использование в учебном процессе вуза в ходе профессиональной подготовки будущих дизайнеров, так как выявлены основные принципы создания дизайн-проекта фирменного стиля компании и показана возможность их реализации.

\section{Список литературы:}

1. Ажгихин С.Г. Информационные технологии в дизайнерском творчестве // Информатика и образование. 2007. № 12. С. 68-71.

2. Бурцев М., Рыбцов И. Фирменный стиль, который продает.

URL: http://www.rb-edu.ru/library/articles/articles_5077.html

3. Кубань изыскания. URL: http://www.kuiz.su

4. Марченко М.Н. Влияние дизайнерской деятельности на развитие способностей, обучающихся $\kappa$ творчеству // Международный журнал экспериментального образования 2013. № 11-13. С. 201-203.

5. Муштаев Д. Новые тенденции в создании фирменных стилей. URL: http://www.advertology.ru.htm

6. Попов С.Г. Основы маркетинга, учебное пособие. СПб., 2001.

7. PocmГеоCтрой. URL: http://www.rostgeostroi.ru

8. СевКавТисиз. URL: http://www.sktisiz.ru/about/

9. Харт Ф. Создание успешного бренда. Как управлять мотивацией потребителя. М., 2005.

\section{References:}

1. Azhgikhin S.G. Information technology in the design works // Computer science and education. 2007. № 12. Pp. 68-71.

2. Burtsev M.I. Corporate Identity, which sells. URL: http://www.rb-edu.ru/library/articles/articles_5077.html

3. Kuban surveys. URL: http://www.kuiz.su

4. Marchenko M.N. Influence of design activities for the development of abilities of students to be creative // International Journal of Experimental Education 2013. № 11-13. Pp. 201-203.

5. Mushtaev D. New trends in corporate identity. URL: http: //www.advertology.ru.htm

6. Popov S.G. Principles of Marketing, tutorial. SPb., 2001.

7. RostGeoCtroy. URL: http://www.rostgeostroi.ru

8. SevKavTisiz. URL: http://www.sktisiz.ru/about/

9. Hart F. Creating a successful brand. How to manage consumer motivation. M., 2005.

(C) 2014, Марченко М.Н., Ивашечкина Е.А. Дизайн фирменного стиля компаний, специализирующихся на геолого-геофизических изысканиях
(C) 2014, Marchenko M.N., Ivashechkina E.A. Corporate Identity design of companies specializing in geological and geophysical explorations 


\title{
Марченко М.Н., Федосеева А.А. Методика и методы предпроектного анализа при дизайн-проектировании фирменного стиля студии ручной работы
}

\author{
Marchenko M.N., Fedoseyeva A.A. \\ Methodology and methods of the predesign analysis at design \\ engineering of the corporate style of studio of handwork
}

В статье описаны проблемы, возникающие при дизайн-проектировании фирменного стиля, $а$ также способы их решения посредством различных методик и методов. Также в статье приведены примеры, как данные методики применялись при дизайн-проектировании фирменного стиля студии ручной работы

Ключевые слова: фирменный стиль, методика предпроектного анализа, дизайн-проект, ручная работа, дизайнерское решение, профессиональная подготовка

\section{Марченко Марина Николаевна}

Доктор педагогических наук, профессор, зав. кафедрой

Кубанский государственный университет

2. Краснодар, ул. Ставропольская, 149

\section{Федосеева Алена Александровна}

Магистрант

Кубанский государственный университет

2. Краснодар, ул. Ставропольская, 149
In the article the problems arising in the process of designing of a corporate style and the ways of their decision by means of various techniques and methods are discussed. Some examples, which describe the ways these techniques were applied in the process of design of a corporate style of the studio of handmade goods of "Vozhik" are also given in the article. The results of this research can be used in the educational process during professional training of future designers

Key words: corporate style, methods of the predesign analysis, design project, handwork, design decision, professional training

\author{
Marchenko Marina Nikolaevna \\ Doctor of Pedagogic Sciences, Professor, head of \\ Department \\ Kuban State University \\ Krasnodar, Stavropolskaya st., 149
}

\author{
Fedoseyeva Alena Aleksandrovna \\ Undergraduate \\ Kuban State University \\ Krasnodar, Stavropolskaya st., 149
}

Суть методики предпроектного анализа состоит в расчленении процесса исследования предлагаемой дизайнеру ситуации на ряд этапов, самостоятельных по целям и результатам работ [5].

Сбор данных на предпроектном этапе в процессе создания проекта включает в себя такие методы как беседа с заказчиком или потребителем; знакомство с местом проектирования; изучение сути проектирования; изучение методической литературы; изучение специальной литературы; сбор социологи- 
ческих данных о потребителе; проведение ряда социологических опросов; изучение аналогового материала.

Подготовительный этап являет собой мыслительную деятельность, которая предшествует выполнению проекта.

Методологический анализ - выработка взгляда на проект под углом зрения мировоззрения автора. Методологическая фаза способствует творческой инициативе и создает условия для формирования основной концепции, замысла, идеи или целевой установки, а также помогает установить направление творческого поиска [5].

На этом этапе может быть использован экспериментально-лабораторный метод проектирования. Этот метод основан на использовании в проектировании научного анализа и лабораторных исследований. Он помогает успешно преобразовать результаты объективных исследований в субъективное решение.

1 этап. Обследование, знакомство с ситуацией, контекстом размещения будущего объекта, перечнем свойств, которыми он должен обладать. Техника этого этапа: изучение аналогов, обзор литературных данных и реальных прототипов, выяснение их положительных и отрицательных качеств, формулировка прямых задач дальнейшей работы.

2 этап. Дизайнер ставит перед собой задачу восприятия задания как проблемы, т.е. столкновения противоречий между обстоятельствами будущей жизни объекта и эксплуатационными характеристиками его структур.

3 этап. Сравнение предложений, рассматривающее отдельные аспекты проблемы, сведение их в разные варианты общего решения, и выбор среди этих вариантов наиболее эффективного. Это еще не проект, а дизайнконцепция, принципиальная дизайнерская идея будущего проекта, но уже содержащая его реально представимые формы: инженерно-технические, пространственные, процессуальные и т.д. [6].

Структура проектной деятельности сложна и включает следующие моменты:

- синтез воображения и абстрактного мышления, воображения и рассудка, интуитивного и дискурсивного;

- способность предвосхищения, антиципация;

- синтез внутреннего, сокровенного, имманентно присущего творцу и внешнего, даваемого культурой и обстоятельствами;

- консистенция знаний;

- игровой момент;

- единство отражения и преображения действительности;

- единство сознательного и бессознательного;

- единство новаторского и репродуктивного [6].

Когда мы осмысливаем вещь на стадии ее существования в качестве проекта, то понимаем, что эта вещь еще не существует, но задумана и должна появиться [7]. Человек совершает выбор между существующим и несуществующим в пользу того, что пока отсутствует. [8]. 
Все варианты задач композиционной организации средовых комплексов можно разделить на две группы: "проектирование без аналогов" - создание объектов принципиально новых, где синтезируются не встречавшиеся ранее технические, пространственные и образные параметры; "проектирование по прототипам" - внесение новых качеств в облик или техническое решение объектов и систем, уже знакомых потребителю. Речь идет о совершенствовании, модернизации зарекомендовавшего себя приема организации среды, приспособление отработанной технической или пространственной схемы к новым вкусам или обстоятельствам [2].

Существует большое количество методов проектирования. Выбор метода дизайнером зависит от поставленных целей и задач. Так же выбор метода основывается на обстановке, ситуации в которой решается данный объект. Далее разберем четыре основных метода проектирования в дизайне.

1. Унификация и агрегативность.

В теоретическом сознании представителей технической сферы унификация рассматривается как один из главных органов управления индустриальным производством предметной среды. Цель унификации - «повышение эффективности общественного производства путем упорядочивания, рационального сокращения числа видов возможных объектов и приведение их к единообразию» [3, с. 15]. Отсюда основная задача унификации - определение количества изделий, необходимых для удовлетворения потребностей общества. Унификация понимается как многоаспектная, многоуровневая деятельность во всех сферах человеческой деятельности со своими целями, объектами и методами осуществления. Результат унификации совместимость, заменяемость, повторяемость объектов на основе преемственности. Основной принцип унификации - повышение разнообразия систем при минимуме элементов. Как правило, выделяют два основных направления внедрения унификации в проектную практику:

1. Типовая, осуществляемая путем создания и выпуска унифицированных рядов однородных изделий, с базовыми моделями и модификациями.

2. Межтиповая, достигаемая путем создания и применения в разнородных изделиях одних и тех же унифицированных элементов (агрегатов, узлов и деталей). Межтиповая унификация связана с пространственной перекомпоновкой однородного или разнородного состава унифицированных элементов, то есть агрегатированием [7].

Агрегативность определяется в связи с процессом унификации и применению типовых решений - как «метод проектирования изделий, разнообразных по назначению, из ограниченного количества элементов многократного использования путем изменения характера соединений и пространственного сочетания этих элементов» [2, с. 35]. Агрегативность - метод создания и эксплуатации изделий, основанный на геометрической и функциональной взаимозаменяемости отдельных элементов и узлов, каждый из которых может быть использован при создании различных модификаций изделия. Использование этого метода проектирования позволяет создать необходимые для потребителя новые изделия. 


\section{2. Структурное моделирование.}

Данный метод является свободной компоновкой первичных модульных элементов в разнообразные по конфигурации и связям системы и структурные комплексы. «Метод структурного моделирования используется при поисках и разработке гибких, открытых для развития систем, обладающих композиционной способностью «присоединяемости» [3, с. 45]. Метод гармонично увязывает требования унификации при индустриальном производстве с возможностью индивидуализации отдельных композиционных решений и является гибким средством организации разнообразных предметно-пространственных образований [7].

\section{3. Инверсия.}

Инверсия - это перестановка слагаемых. Метод инверсии позволяет преодолевать критические ситуации в проектировании за счет изменения угла зрения на объект работы; за счет смены творческой установки и так далее. Свежий взгляд на предмет дает новые варианты решения той же задачи, развив воображение, позволяет увидеть в уже отвергнутом предложении неиспользованные резервы. Те же задачи, но несколько иначе, решает прием проектирование в воображаемых условиях, когда реальные обстоятельства работы объекта условно подменяются неожиданными решениями или даже фантастическими.

4. «Мозговая атака».

Метод и термин "мозговая атака", или " мозговой штурм", предложен американским ученым А.Ф. Осборном. Эвристический диалог "мозговой атаки", базируется на ряде психологических и педагогических закономерностей, но прежде чем их сформулировать, следует кратко остановиться на тех теоретических предпосылках, которыми руководствовались создатели этого метода. Изобретателями было отмечено, что коллективно генерировать идеи эффективнее, чем индивидуально.

В обычных условиях творческая активность человека часто сдерживается явно и не явно существующими барьерами (психологическими, социальными, педагогическими и т.д.). К ним, как правило, относят жесткий стиль руководства, боязнь ошибок и критики, сугубо профессиональный и слишком серьезный подход к делу, давление авторитета более способных товарищей, традиции и привычки, отсутствие положительных эмоций и др.

Диалог в условиях "мозговой атаки" выступает в роли средства, позволяющего убрать возможные барьеры, высвободить творческую энергию участников решения творческой задачи.

Мозговой штурм, как и любой другой метод поиска новых решений, имеет свою цель и методику проведения. Цель мозговой атаки является получение максимального количества новых идей за счет взаимного стимулирования членов группы к интенсивному интеллектуальному поиску. Преимуществом метода заключается в неограниченности спектра проблем, к которым он может быть применен: с помощью метода мозговой атаки можно рассматривать любую проблему, если она достаточно просто и ясно сформулирована. Этот метод используется на любой стадии проектирования, как в начале, когда про- 
блема еще окончательно не определена, так и позднее, когда уже выделены сложные подпроблемы.

Еще одно преимущество метода заключается в том, что от участников мозгового штурма требуется минимальная предварительная подготовка. В ряде случаев оказывается полезным привлечение людей, никогда ранее не занимавшихся обсуждаемыми проблемами.

Реальные методики обычно содержат в себе в той или иной степени элементы всех рассмотренных типов, каждый из которых чем-то дополняет другие [3].

Перечисленные проектные методики были использованы при разработке фирменного стиля хендмейд-студии «Вожик». Особенное внимание было уделено методике «Мозговая атака». Были опрошены люди от 12 до 27 лет (целевая аудитория магазина хендмейд-студии «Вожик» в социальной сети Вконтакте), через которую будет реализовываться товар (в основном его количестве). Задан вопрос, какое животное и цвет ассоциируется у них при словах «рукоделие», «трудолюбие», «теплота». В результате этого опроса было выявлено, что при этих словах у опрошенных возникают в воображении животные: лиса, еж, енот, медведь и цвета: древесный (тепло-коричневый), соломенный, травянисто-зеленый, кирпичный, землистый. Решающим фактором выбора того или иного животного и цветовой гаммы было пожелание заказчика. На основе опроса и пожеланий заказчика было решено взять за основу знак с изображением ежа и «теплую» цветовую гамму, а именно цвета: соломенный, тепло-коричневый, черный (для поддержания контраста) и белый (для выгодной подачи). Было предусмотрено использование различных природных текстур.

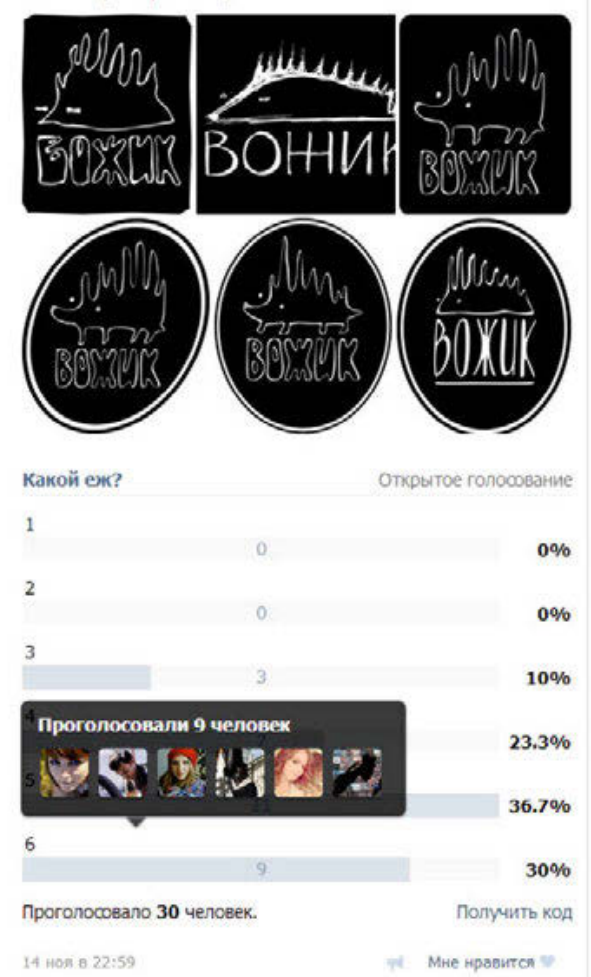

Puс. 1. Результаты опроса 
Проведен социальный опрос, в ходе которого опрашиваемым предлагалось выбрать товарный знак хендмейд-студии «Вожик». Опрашиваемым предоставлялось шесть различных вариантов торгового знака с различным начертанием названия. В результате опроса большинство проголосовало за вариант №5, но при выборе товарного знака были предпочтительны пожелания заказчика и дизайнера. В итоге выбран товарный знак под номером 6 (рис. 1). Так же были учтены и комментарии опрашиваемых (рис. 2).

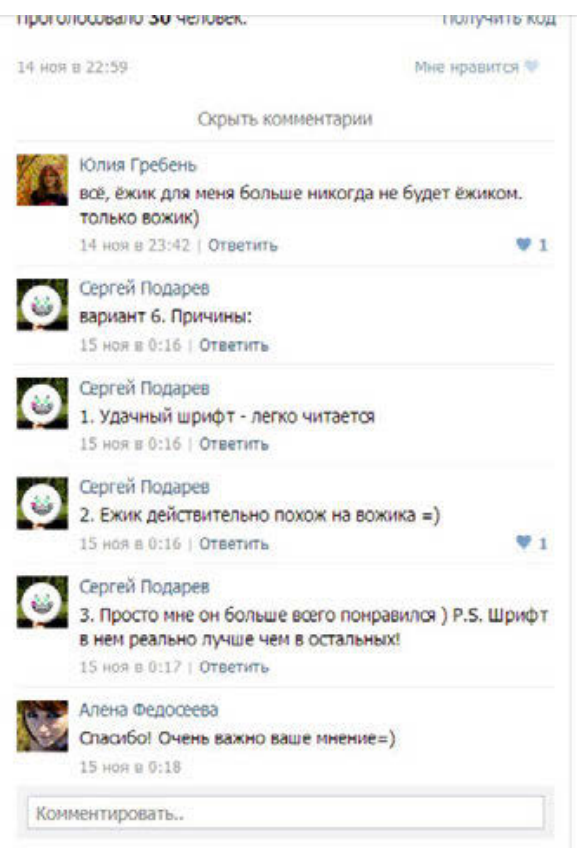

Pис. 2. Комментарии опрашиваемых
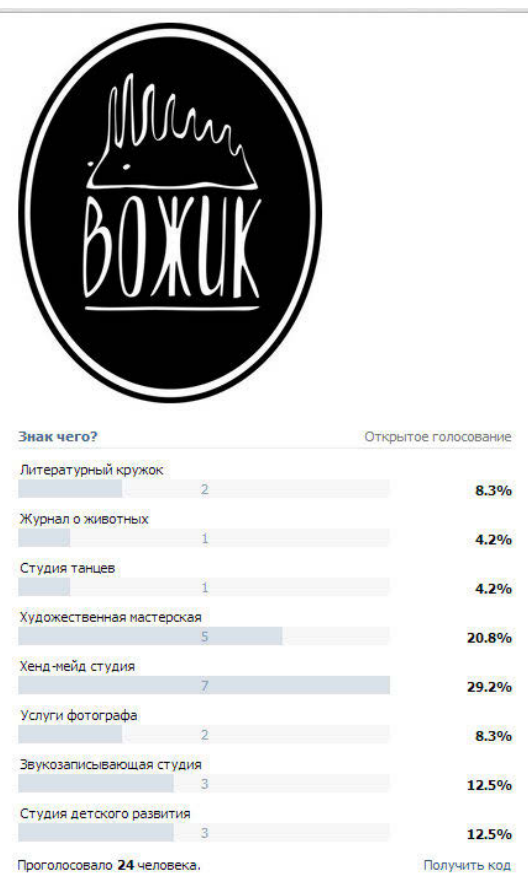

Puc. 3. Ассочиативный опрос 
После того, как был определен знак, проведен новый опрос, в ходе которого опрашиваемым предлагалось определить, какие услуги предполагает выбранный ими товарный знак. Большинство испытуемых проголосовало за вариант № 5 («Хендмейд-студия»), что абсолютно точно соответствует истине. Следовательно, у потребителя данный образ знака ассоциируется с ручным трудом (рис. 3).

В процессе дизайн-проектирования были использованы такие методы исследования, как:

- беседа с заказчиком;

- знакомство с предметом проектирования (изделия ручной работы);

- изучение методической литературы;

- изучение специальной литературы;

- сбор социологических данных о потребителе (о поле и возрасте потенциальных покупателей);

- проведение ряда социологических опросов (о выборе лучшего товарного знака и на наличие ассоциаций с выбранным товарным знаком);

- изучение аналогового материала.

Были изучены методология и принципы проектирования, произведен анализ аналогов, в ходе которого были выявлены некоторые особенности. Например: чтобы выделяться среди конкурентов, нужно иметь яркий, стильный, выдержанный, запоминающийся дизайн; цветовые и тоновые контрасты должны выигрышно обыгрывать фирменный стиль; фирменный стиль должен быть решен оригинально на основе креативной дизайнерской идеи. Эти выводы помогли нам в создании собственного дизайн-проекта. Так же был осуществлен подбор изображений, цветовой гаммы и шрифтов.

В результате проведенного исследования были установлены некоторые особенности проектирования дизайна полиграфической продукции. Были выявлены особенности ручной работы, специфика применения некоторых законов композиций и цвета. Все элементы полиграфии выдержаны в едином стиле, приятны и спокойны по цветовой гамме.

В результате проведенного социологического исследования отмечено, что фирменный стиль удался, отвечает поставленным задачам и соответствует концепции. Фирменный стиль готов к реализации и воплощен заказчиком. Результаты проведенного исследования могут быть использованы в учебном процессе вузов в ходе профессиональной подготовки будущих дизайнеров.

\section{Список литературы:}

1. Ажгихин С.Г. Формирование технологических знаний студентов вузов в процессе обучения проектированию в графическом дизайне // Историческая и социально-образовательная мысль. 2011. № 3. С. 39-43.

2. Ахмедов Г.Г. Организация архитектурно-дизайнерской деятельности. М.: МГУТУ, 2012.

3. Грашин А.А. Методология дизайн-проектирования элементов предметной среды. М.: Архитектура, C. 2004.

4. Марченко М.Н. Графическая деятельность и компьютерные технологии в профессиональной подготовке будущих дизайнеров // Историческая и социально-образовательная мысль. 2013. № 5 (21).

C. $115-118$.

5. Методика подхода к проектированию объектов дизайна среды.

URL: http://5fan.ru/wievjob.php?id=36196. 
6. Методы проектирования в дизайне и разработка дизайн-конщепщий.

URL: http://www.taby27.ru/studentam_aspirantam/philos_design/referaty_philos_design/conzept_design/307

7. Минервина Г.Б., Шимко В.Т. Дизайн: Основные положения. Виды дизайна. Особенности дизайнпроектирования. Мастера и теоретики. М.: Архитектура, С. 2004.

8.Мосоров А.М., Мосорова Н.Н. Теория дизайна. Екатеринбург: Солярис, 2004.

\section{References:}

1. Azhgikhin S.G. Formation of technological knowledge of students of higher education institutions in the course of training in design in graphic design // Historical and social and educational thought. 2011. № 3. Pp. 39-43.

2. Akhmedov of G.G. Organization of architectural and design activity. M.: MGUTU, 2012.

3. Grashin A.A. Methodology of design engineering of elements of the subject environment. M.: Architecture, With, 2004.

4. Marchenko M.N. Graphic activity and computer technologies in vocational training of future designers //

Historical and social and educational thought. 2013. № 5 (21). Pp. 115-118.

5. Technique of approach to design of objects of design of the environment.

URL: http://5fan.ru/wievjob.php? id=36196.

6. Design methods in design and development of design concepts.

URL: http://www.taby27.ru/studentam_aspirantam/philos_design/referaty_philos_design/conzept_design/307 7. Minervina G.B., Shimko V.T. Design: Basic provisions. Types of design. Features of design. Masters and theorists. Il. words. M.: Architecture, 2004.

8. Mosorov A.M., Mosorova N.N. Theory of design. Yekaterinburg:Solaris, 2004.

(C) 2014, Марченко М.Н., Федосеева А.А.

Методика и методы предпроектного анализа при дизайн-проектировании фирменного стиля студии ручной работы
(C) 2014, Marchenko M.N., Fedoseyeva A.A.

Methodology and methods of the predesign analysis at design engineering of the corporate style of studio of handwork 
DOI: $10.17117 /$ no.2014.01.100

Поступило в редакцию: 24.11.2014

rector@kubsu.ru

\title{
Марченко М.Н., Силищева Ю.В. Дизайн-проект специализированного экспоцентра для крупногабаритных экспонатов
}

\author{
Marchenko M.N., Silischeva Yu.V. \\ Design project of a specialized expo-center for large-scale exhibits
}

В данной статье выявлены основные проблемы и обоснована необходимость создания специализированного экспоцентра для крупногабаритных экспонатов в Краснодарском крае. В ходе работы выявлены основные принципы проектирования выставочных комплексов, которые могут быть использованы в учебном процессе вузов. На примере рассмотренных аналогичных проектов выявлены основные функциональные элементы экспоцентров и предложено решение проблемы путем проектирования экспоцентра с учетом всех эргономических и функциональных требований предъявляемых к организации среды специализированного экспоцентра

Ключевые слова: экспоцентр, крупногабаритные экспонаты, учебный процесс, функциональные элементы экспоцентра, моделирование среды экспоцентра

\section{Марченко Марина Николаевна}

Доктор педагогических наук, профессор, зав. кафедрой

Кубанский государственный университет

2. Краснодар, ул. Ставропольская, 149

\section{Силищева Юна Владимирона}

Магистрант

Кубанский государственный университет 2. Краснодар, ул. Ставропольская, 149
This research article reveals major problems and establishes the necessity to create a specialized venue for large-scale exhibits in Krasnodar Region. This work revealed major principles of expo centers design which can be used in HEI educational process. Using the reviewed examples of similar projects we have determined main functional elements of exhibition centres and offered solution of this problem by means of designing a venue with due consideration of all ergonomic and functional requirements applicable to organization of specialized venue environment

Key words: expocentre, large-scale exhibits, educational process, functional elements of the venue, modeling of the environment of the venue

\author{
Marchenko Marina Nikolaevna \\ Doctor of Pedagogic Sciences, Professor, head of \\ Department \\ Kuban State University \\ Krasnodar, Stavropolskaya st., 149 \\ Silischeva Yuna Vladimirovna \\ Undergraduate \\ Kuban State University \\ Krasnodar, Stavropolskaya st., 149
}

В процессе обучения дизайнерской деятельности, которая интегрирует научно-технические и гуманитарные знания, студент должен освоить закономерности проектной культуры, эстетики, функциональности, грамотной предметной и коммуникативной среды [9]. Поэтому, прежде чем приступить непосредственно к процессу проектирования, обучающийся должен провести ряд определенных исследований касательно интересующей его темы. 
Для создания дизайн-проекта специализированного экспоцентра для крупногабаритных экспонатов необходимо провести анализ предпроектной ситуации. Это поможет студенту выяснить целесообразность постройки такого комплекса на территории Краснодарского края. Изучение аналогичных проектов позволит определить основные принципы, используемые для постройки экспоцентров в России и в мире, а так же и выявить особенности отдельно взятых комплексов.

Интерес к специализированным экспоцентрам во всем мире возрастает по всем мире возрастает по мере развития экономики, промышленности, бизнеса различных регионов мира в целом и нашей страны в частности.

В настоящее время Краснодарский край является одним из самых привлекательных регионов Российской Федерации по многим показателям. Согласно «Стратегии социально-экономического развития Краснодарского края до 2020 года» основу производительных сил Краснодарского края составляют промышленный, строительный, топливно-энергетический комплексы, область информационных и коммуникационных технологий, а также агропромышленный, транспортный, курортно-рекреационный и туристский комплексы. Последние три направления деятельности (агропромышленный, транспортный, санаторно-курортный и туристский комплексы) соответствуют приоритетам социально-экономического развития России и определяют особый статус Краснодарского края в экономике страны. Однако это не случайно, так как на территории края расположены около 4805 тысяч гектаров плодородных земель, в том числе и чернозема [2]. Динамичное развитие агропромышленного комплекса позволяет Краснодарскому краю занимать ведущие места по производству многих жизненно необходимых продуктов таких как: зерно, сахарная свекла, семена подсолнечника, мед, фрукты, мясо, яйца, молоко.

Уникальное географическое расположение края обеспечивает благоприятные природно-климатические условия, которые способствуют не только комфортному проживанию граждан на территории региона, но и активному развитию туристического бизнеса. Месторождения минеральных вод и лечебных грязей, а так же наличие исторических достопримечательностей создают потенциал для развития современного, конкурентоспособного туристско-рекреационного комплекса международного уровня.

Географическое положение уникально и тем, что обеспечивает прямой выход через Азовское и Черное моря на международные внешнеторговые пути. Так же по территории края проходит газопровод Россия-Турция.

Следует отметить и то, что Краснодарский край является одним из регионов России, самостоятельно обеспечивающих свои текущие бюджетные расходы, и при этом вносящим существенный вклад в федеральный бюджет.

Целесообразность строительства экспоцентра для крупногабаритных экспонатов в Краснодарском крае обеспечивается ещё и тем, что Краснодарский край является одним из основных лидеров среди регионов Российской Федерации по уровню инвестиционной активности и стабильно занимает первое место в Южном федеральном округе и пятое - в России. По данным источника «Юга.ру» объем иностранных инвестиций в экономику Краснодарского 
края в 2013 году составил 1,054 млрд. долларов США. Объем прямых инвестиций составил 467,2 млн. долларов США. Значительная доля прямых инвестиций $(44,7 \%)$ была направлена на развитие обрабатывающих производств, из них на производство машин и оборудования $45,2 \%$ и производство пищевых продуктов, включая напитки, и табака 42,4\%. В январе-июне 2014 года, по данным федеральной службы государственной статистики «Краснодарстат», в экономику края вложено 315,0 млрд. рублей [3].

Таким образом, Краснодарский край является весьма привлекательным районом не только для российских, но и для зарубежных инвесторов. Регион имеет огромный потенциал к развитию в различных отраслях экономики.

Неподдельный интерес к южному региону проявляют многие бизнесмены российские и зарубежные компании, на территории края проходят форумы, конференции, деловые встречи. Такое активное развитие бизнеса зачастую требует наличия соответствующих площадок для собственных потребностей. Например: чтобы одним компаниям показать свои достижения и новинки в области машиностроения, а другим ознакомиться с ними, и тем, и другим необходимо покинуть пределы края только лишь потому, что в крае нет площадок для демонстрации такой крупной техники, как комбайны, тракторы и прочая уборочная техника. А для того чтобы попробовать такую технику в действии, потенциальный покупатель снова будет вынужден переместиться с места выставки в местность, где можно будет увидеть представленную технику в работе. Все это вызывает определенный дискомфорт и лишнюю трату времени. Было бы очень удобно организовать выставку таким образом, чтобы в одном месте (в одном комплексе) можно было посмотреть экспонаты не только непосредственно на стенде, но и в действии. Важно отметить, что сельскохозяйственная отрасль нуждается в подобном комплексе, также нуждаются в нем туризм, рекреация, транспортная система, система благоустройства города и многие другие отрасли. Комплекс, позволяющий экспонировать крупногабаритные объекты, может быть востребован для демонстрации моторных лодок, моторизованных яхт, понтонов, плавучих домов, что актуально для водного туризма; судов малой авиации; транспортной техники для общественного пользования; так же для различных средств очистки, переработки, утилизации мусора; осветительной техники для благоустройства города, систем очистки воды, автомобилей для личного пользования и многого другого.

Положительная сторона подобного выставочного комплекса ещё и в том, что на одной площадке, в одном месте встречаются разные поставщики аналогичной продукции, что позволяет им открыто конкурировать. А покупатель, в свою очередь, имеет возможность сравнить ценовую политику и качество исполнения предлагаемых товаров, отбросив все маркетинговые уловки. Таким образом, сводя представителей производителя с потенциальными покупателями решаются сразу несколько задач - это и прямая реклама компании, и наглядная демонстрация товара для производителя, а для покупателя - это возможность узнать о всех достижениях в интересующей его отрасли, а так же возможность тщательного анализа всего ассортимента товара и выбор исключительно того, который отвечает всем требованиям. 
Для разработки дизайн-проекта специализированного экспоцентра для крупногабаритных экспонатов обучающимся необходимо ознакомиться с аналогичными комплексами и выявить их преимущества и недостатки.

Одним из самых крупных и популярных в крае комплексов является выставочный центр «КраснодарЭКСПО». Данный центр находится в городе Краснодаре, общая выставочная площадь составляет 37000 м2, в том числе 18200 м2 - закрытая выставочная площадь, 19100 м2 - открытая выставочная площадь [4]. «КраснодарЭКСПО» реализует такие выставочные проекты как Международный агропромышленный форум "ЮГАГРО", Южный туристический форум, Южный архитектурно-строительный форум, "UMIDS", "Южный мебельный и деревообрабатывающий салон", "MOBI", "Прибыльное гостеприимство", форум "Создай себя сам", однако, несмотря на то, что комплекс специализируется на организации и проведении всевозможных выставок, в центре отсутствует возможность доставки крупногабаритной техники, так как комплекс расположен в самом городе, и затруднение или полная остановка движения городского потока транспорта будет весьма проблематична. Так же отсутствуют и альтернативные пути доставки экспонатов, такие, например, как железная дорога. Расположение таких крупных объектов как выставочные комплексы внутри города, с одной стороны, решают проблему доставки посетителей к месту выставки и делает ее максимально открытой и общедоступной, но, с другой стороны, во-первых, ограничивает комплекс в площадях и, во-вторых, усложняет транспортную инфраструктуру.

Вопросами проектирования подобных комплексов занимались: Арас Агаларов глава компании "Крокус групп", принимая активное личное участие в ходе проектирования и строительства комплекса "Крокусэкспо", компания «Messe Berlin GmbH» (немецкая компания - оператор «Мессе Берлин» Берлинского международного конгресс-центра). При этом специальных исследований в просмотренном объеме источников не найдено.

В процессе исследования аналогичных комплексов в мире, таких как «Мессе Берлин», «Крокусэкспо», «Гонконгский Центр Конвенций и Выставок», выставочный комплекс «INCHEBA EXPO PRAHA» в г. Прага, «ExCel» в Лондоне обучающимися были выявлены определенные проблемы, которые должен решать подобный комплекс.

В ходе предпроектных исследований по теме, посвященной дизайнразработке специализированного экспоцентра для крупногабаритных экспонатов, были выявлены следующие важные моменты. На начальной стадии проектирования студентам необходимо очень тщательно подойти к выбору места постройки такого комплекса, потому как от этого будет зависеть дальнейшая состоятельность проекта. Следует обратить внимание на такие параметры, как близость к крупному городу. Это может быть как в черте города, так и его пригороде. Следует учесть так же и то, что выставочный центр должен обладать обширной территорией, тем более, если речь идет о выставке крупногабаритных объектов, поэтому размещение в густонаселенный районах города лучше исключить. «КраснодарЭКСПО» занимает территорию равную 37000 м2, а «Крокусэкспо», для сравнения, 548000 м2 , московский комплекс 
«Экспоцентр» занимает площадь равную 165000 м2, в комплексе «Мессе Берлин» расположились 26 выставочных залов, общей площадью на 160000 м2, одним из самых крупных мировых выставочных центров является комплекс «Deutsche Messe» в Ганновере, его общая площадь составляет 1 млн. м², в том числе $478900 \mathrm{~m}^{2}$ занимают 26 крытых павильонов и $227700 \mathrm{~m}^{2}$ - открытые площади. Несомненным преимуществом является подход железнодорожных веток к территории комплексов, как в «Мессе Берлин», в котором располагается более чем 2000 м железнодорожных путей, что позволяет не только быстро и удобно доставлять грузы для выставок, но и демонстрировать железнодорожный транспорт [6].

В процессе моделирования среды экспоцентра обучающимся необходимо учесть все аспекты, влияющие на эргономику пространства. Важно помнить, что в комплексе будут экспонироваться крупные объекты, в связи с чем студенты должны тщательно продумать весь функционал комплекса. Отдельное место необходимо выделить и для всевозможной погрузочно-разгрузочной техники, а также специальным разгрузочным площадкам и ангарам для хранения этого оборудования. Важно организовать маршруты движения специализированной техники таким образом, чтобы максимально сократить время предварительной подготовки. Современные выставки, например, Московский международный автомобильный салон 2014, проходивший в «Крокусэкспо», широко применяют сооружения из металлоконструкций, имитирующих сложный рельеф дороги, каменистые насыпи, водные преграды для того, чтобы наглядно показать посетителям сильные стороны экспонируемых автомобилей (рис. 1).

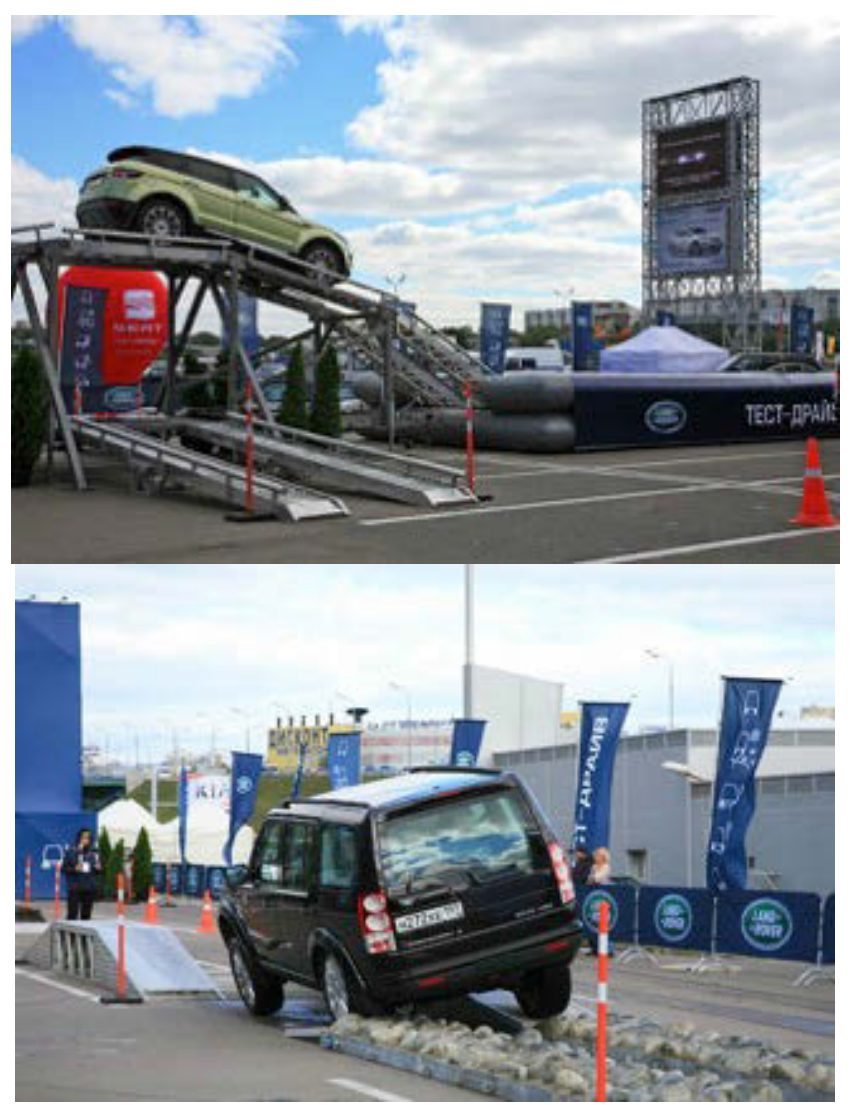

Рис. 1 Конструкции, имитирующие сложный рельеф 
Подобные конструкции так же требуют должного технического оснащения, места для монтажа таких конструкций и для хранения деталей [5].

Несмотря на всю сложность инфраструктуры комплекса, центр должен отвечать всем привычным стандартам комфорта и эргономики. С точки зрения рядового посетителя схема пользования и перемещения по центру должна быть максимально проста и понятна. Пешеходные маршруты не должны пересекаться с транспортными маршрутами, гости и участники выставки не могут быть подвержены никакой опасности в ходе рабочего процесса комплекса. Для посетителей центра необходимо организовать питание, места для отдыха, так как событие такого масштаба предполагает довольно длительное пребывание в центре.

Неотъемлемой частью комплекса является инфоцентр с полной развернутой информацией о проходящей выставке, будущих выставках и об объекте в целом. Информация должна содержать подробную схему комплекса, данные об участниках и программу мероприятия. Подача материала должна быть понятной общедоступной, это может быть и видеоинформация, и интерактивные инфоматы, и обычная печатная продукция, которую посетитель может взять с собой на время посещения выставки и после него. Навигация по центру также должна быть тщательно продумана и понятна как для российских, так и для иностранных граждан.

Не следует забывать и о том, что подобный комплекс - это, прежде всего, бизнес пространство, которому сопутствуют многочисленные переговоры, конференции, симпозиумы, сейшены, кофе-брейки. Каждый участник хочет извлечь для себя максимальную пользу в кратчайшие сроки, в связи с чем возникает потребность в конференц залах различной вместимости с современным оснащением, в переговорных зонах, зонах свободного общения для, так называемых встреч "без галстуков". Также важно продумать и размещение организаторов и экспонентов, учитывая то, что они могут быть жителями других городов и стран. Для этого на территории комплекса необходимо разместить отель для временного проживания на период подготовки и проведения выставочных мероприятий и ресторан. Обращаясь к опыту уже имеющихся аналогичных комплексов, а именно к большому и современному Гонконгскому конгресс-центру, который считается лучшим в Азии, хотелось бы отметить интересное рациональное решение соединить гостиницу с выставочным комплексом. Гонконгский центр конвенций и выставок (Hong Kong Convention and Exhibition Center) является центром деловой активности в регионе, поэтому идея соединить конгресс-центр с двумя роскошными гостиницами мирового класса - Grand Hyatt Hong Kong и Renaissance Harbour View Hotel - была вполне взвешенным и обдуманным ходом [7].

Внешний вид, как и все другие факторы, является не менее важной составляющей успеха комплекса. Сегодня современного посетителя уже трудно удивить, поэтому лучшие архитекторы и проектировщики мира бьются над решением не только проектно-эргономических задач, но и над эстетической составляющей внешнего облика комплекса. И «Центр конвенций и выставок» в Гонконге яркий тому пример. 


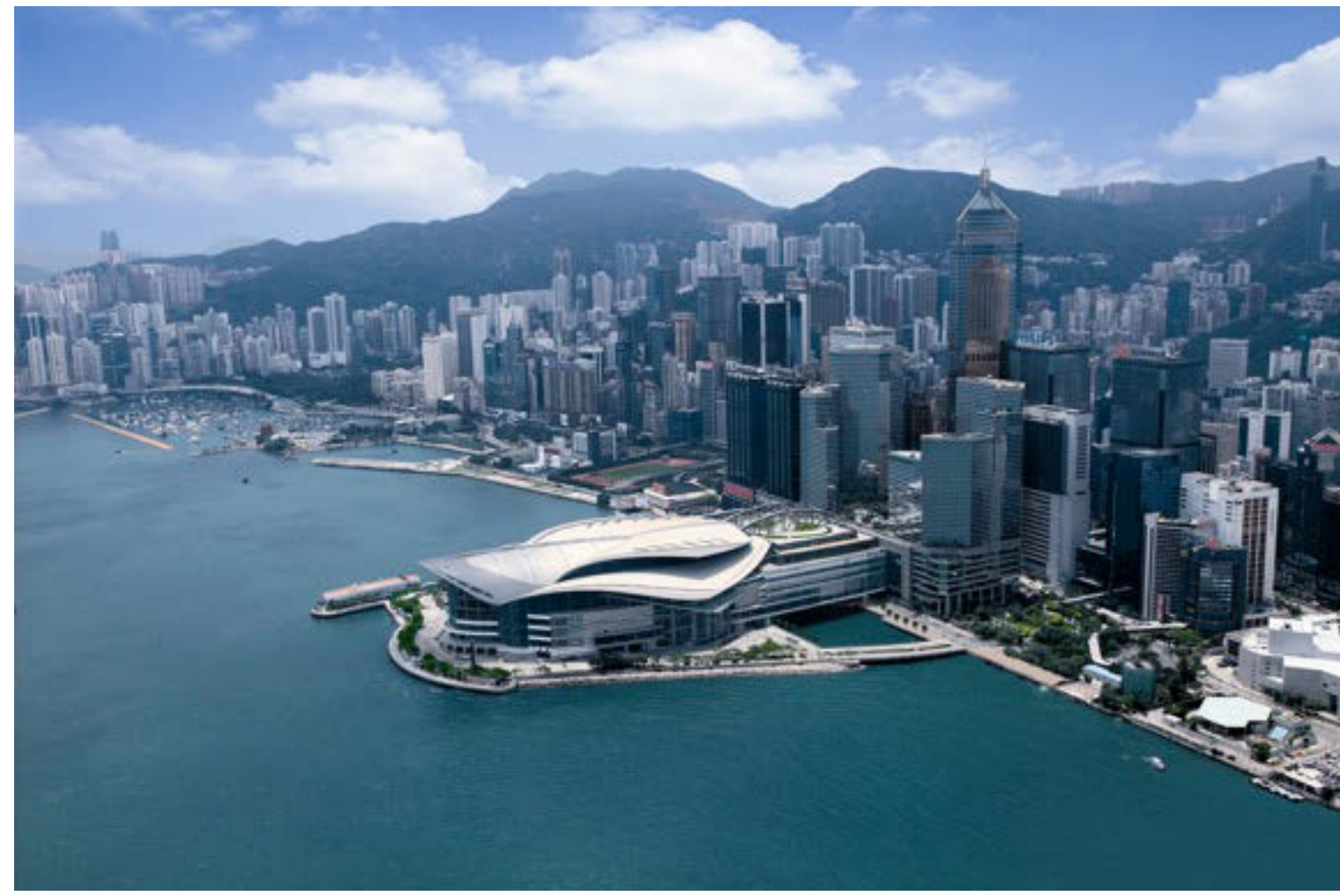

Рис. 2 «Центр конвенций и выставок» в г. Гонконг

В отличие от подавляющего большинства крупных выставочных комплексов, гонконгский «Центр конвенций и выставок» резко отличается от привычной, традиционной, горизонтальной планировки выставочных центров и представляет собой довольно компактный многоэтажный комплекс (рис. 2). Однако сделано это отнюдь не из соображений удобства или экономии места, а из-за жесткого дефицита и огромной стоимости земельной территории в Гонконге. Тем не менее общая площадь, на сегодняшний день, составляет 64000 м2, а внешний вид центра вызывает восхищение. Долгие годы здание расширялось и реконструировалось и, наконец, в 2009 году комплекс приобрел новое, современное звучание. Как и многие архитектурные сооружения Гонконга «Центр конвенций и выставок» имеет свой глубинный смысл: массивная крыша, изготовленная из алюминия, символизирует крыло чайки; высокая стеклянная стена открывает фантастический вид на пролив Виктории - «поймайте настроение, ощутите масштаб».

Из самых запоминающихся центров можно так же выделить выставочный комплекс в Праге «INCHEBA EXPO PRAHA - Exhibition Grounds Holesovice ». Этот выставочный комплекс находится недалеко от центра Праги и отличается уникальным дизайном фасада (рис.3).

Еще один крупный выставочный центр - ExCel в Лондоне - является одним из известнейших мировых центров. В комплексе проводятся такие масштабные мероприятия, как Лондонское бот-шоу, Британская международная автомобильная выставка, празднование юбилея «Звездных войн», Всемирная туристическая ярмарка, Лондонское международное музыкальное шоу, неоднократно проводились показы мод, общественные и социальные проекты, а 
также международная выставка вертолетной индустрии Helitech International. «ExCel London» является ярким примером современной архитектуры.
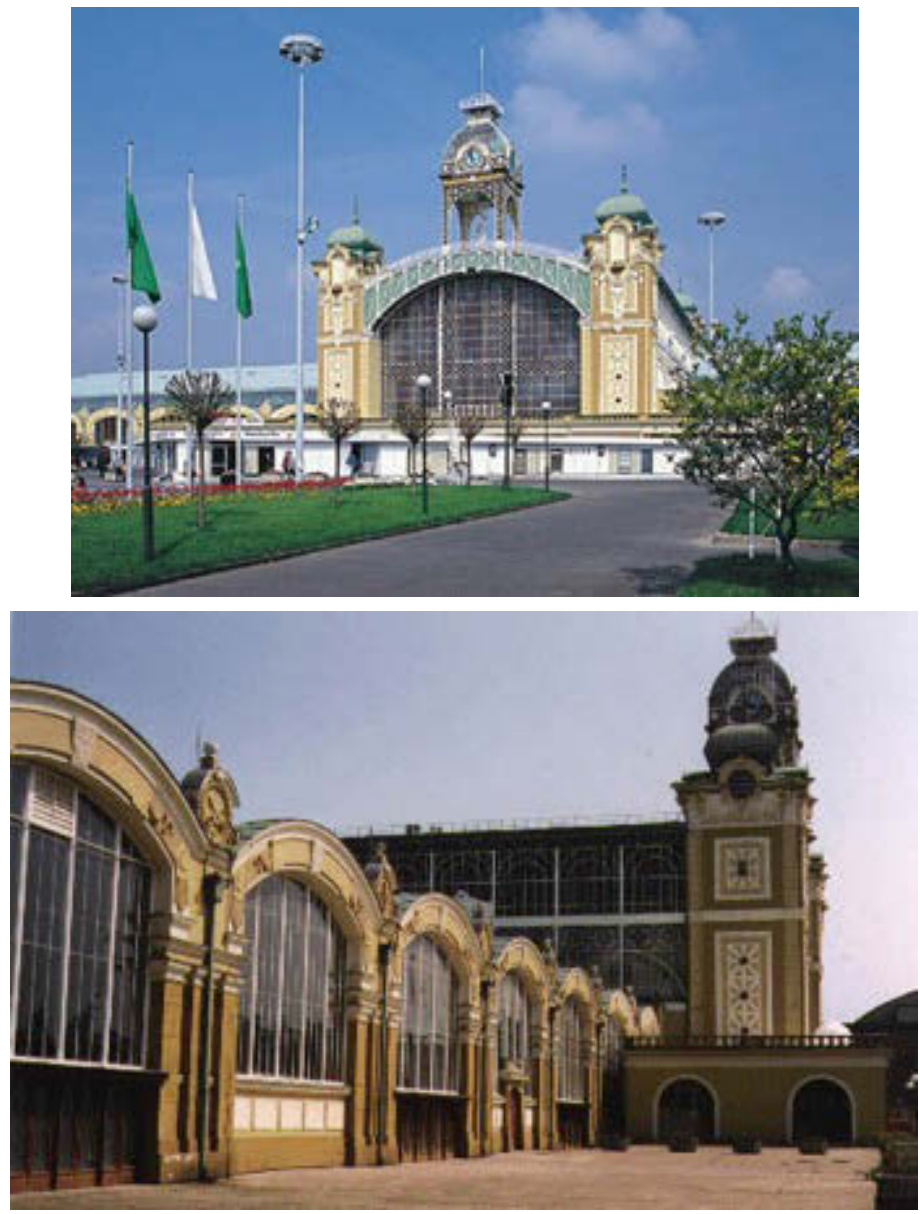

PUс. 3 выставочный комплекс «INCHEBA EXPO PRAHA» в г. Прага

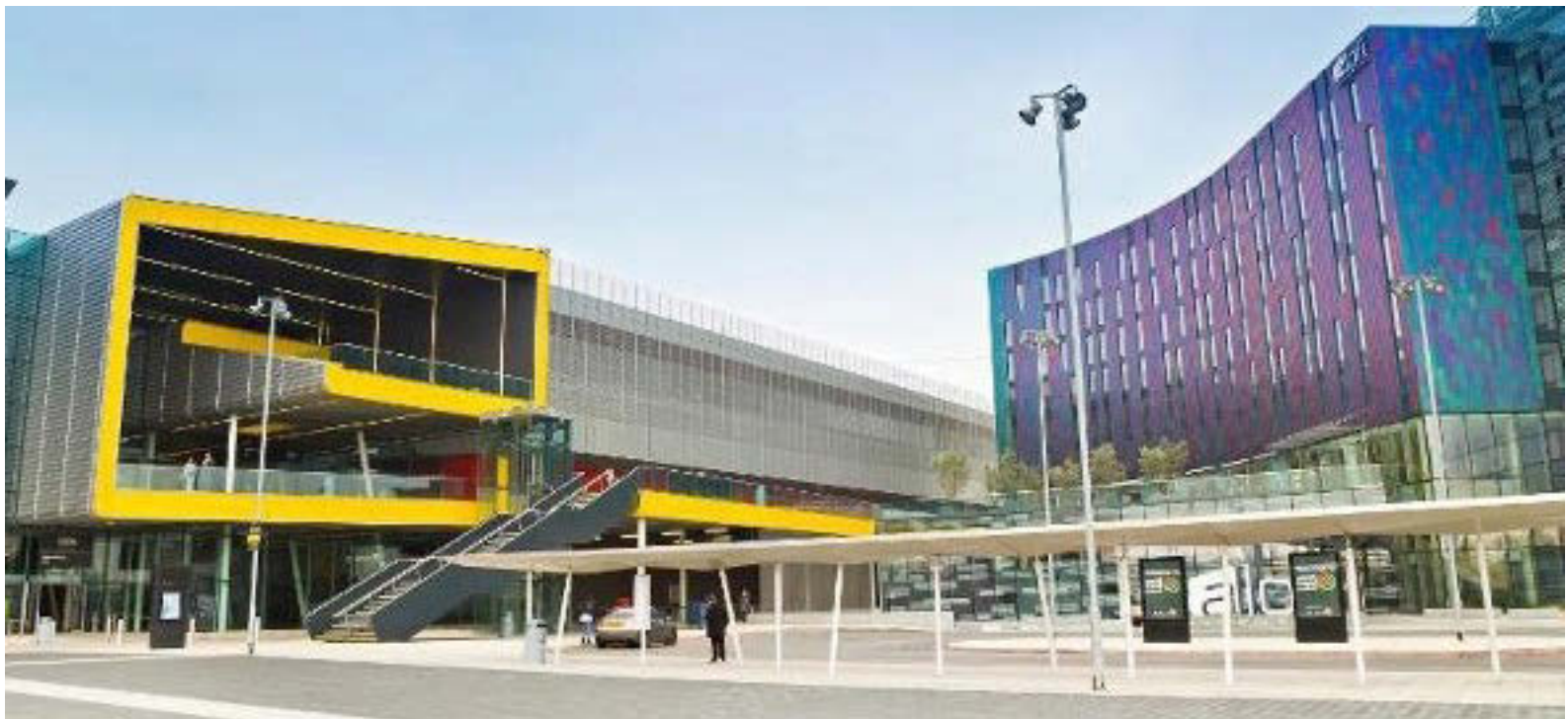

Рис. 4 Выставочный центр «ЕхCel» г. Лондон

Здесь расположен первый в Лондоне международный конференц-центр ICC London, вмещающий самый большой в Великобритании конференц-зал (до пяти тысяч гостей), крупнейший в Лондоне банкетный зал (три тысячи гос- 
тей) и достойный восхищения новый многофункциональный конференцкомплекс с современными комфортабельными помещениями для приемов $(2,5$ тысячи делегатов) [8].

Ознакомившись с аналогами мировых выставочных комплексов, отметив их сильные стороны, важно почерпнуть именно то, что будет актуальным для Краснодарского края, и то, что будет выделять его из ряда других комплексов такого масштаба, необходимо планировать комплекс с учетом всех особенностей местности и социума.

Положительная динамика развития Краснодарского края открывает перспективы для дальнейшего роста экономики в целом и выхода на мировую арену. Лидерские позиции края в области инвестиционной привлекательности говорят о готовности инвесторов вкладывать в регион. Вместе с этим мировую известность и положительный имидж страны в целом и Краснодарскому краю в частности создают недавно успешно проведенные крупные мероприятия, такие как Олимпиада 2014 и 65-й сезон Формулы-1. Все это позволяет сделать выводы о целесообразности строительства специализированного экспоцентра для крупногабаритных экспонатов в Краснодарском крае.

К необходимым функциональным элементам специализированного экспоцентра для крупногабаритных экспонатов следует относить:

- большую территорию комплекса;

- железнодорожные пути;

- автомобильные пути;

- автомобильные парковки;

- погрузо-разгрузочные площадки;

- складские помещения;

- службы для приема посетителей;

- инфоцентр;

- гостиница;

- неординарный формообразующий и оформительско-декораторский принцип решения всего комплекса.

В ходе работы над дизайн-проектом специализированного комплекса для крупногабаритных экспонатов были выявлены основные принципы работы для студентов вузов. Была определена последовательность работы, включающая постановку задачи, сбор информации, функциональный анализ и выявление главных и второстепенных критериев объекта изучения.

Весь полученный материал можно использовать в образовательном процессе высших учебных заведений [1; 9].

\section{Список литературы:}

1. Ажгихин С.Г. Формирование технологических знаний студентов вузов в процессе обучения проектированию в графическом дизайне // Историческая и социально-образовательная мысль: научный журнал. 2011. № 3 (8).

2. Администращия Краснодарского края. URL: http://www.krasnodar.ru

3. Государственная статистика. URL: http://www.krsdstat.gks.ru

4. Информация о комплексе «КраснодарЭКСПО», г. Краснодар. URL: http://www.krasnodarexpo.ru

5. Информация о комплексе «Крокусэкспо», г. Москва. URL: http://www.crocus-ехро.ru

6. Информация о комплексе «мессе Берлин». URL: http://www.messe-berlin.com 
7. Информация о комплексе «Центр конвенций и выставок», г. Гонконг. URL: http://wikipedia.org

8. Информация о комплексе «ExCel», г. Лондон. URL: http://www.mice.ru

9. Марченко М.Н. Влияние дизайнерской деятельности на развитие способностей обучающихся к творчеству // Международный журнал экспериментального образования: научный журнал. 2013. № 11.

\section{References:}

1. Azhgikhin S.G. Development of technological knowledge of students in higher educational institutions in the process of studying project engineering in graphic design // Historical and socio-educational idea: research magazine. 2011. № 3 (8).

2. Administration of Krasnodar Region. URL: http://www.krasnodar.ru

3. Government statistics. URL: http://www.krsdstat.gks.ru

4. Information on KrasnodarExpo complex, Krasnodar. URL: http://www.krasnodarexpo.ru

5. Information on CrocusExpo complex, Moscow. URL: http://www.crocus-expo.ru

6. Information on the MesseBerlin complex. URL: http://www.messe-berlin.com

7. Information on Centre of Conventions and Exhibitions complex, Hong Kong. URL: http://wikipedia.org

8. Information on ExCel complex, London. URL: http://www.mice.ru

9. Marchenko M.N. Influence of design activity on development of students' creative capacity // International magazine of experimental education: research magazine. 2013. № 11.

(C) 2014, Марченко М.Н., Силищева Ю.В. Дизайн-проект специализированного экспоцентра для крупногабаритных экспонатов
(C) 2014, Marchenko M.N., Silischeva Yu.V. Design project of a specialized expo-center for largescale exhibits 
DOI: $10.17117 /$ no.2014.01.110

Поступило в редакцию: 18.11.2014

rector@kubsu.ru

\title{
Марченко М.Н., Гвоздева А.П. Графическое оформление современного кулинарного журнала
}

\author{
Marchenko M.N., Gvozdeva A.P. \\ Graphic design of a modern cooking magazine
}

\section{В данной статье описаны основные проблемы на современном рынке периодических изданий в области кулинарии. Авторами проведено исследование специфики дизайна кулинарных журналов. Предоставлено решение проблемы путем разработки нового издания, которое бы удовлетворяло потребности широкой фокус- группы, состоящей как из мужчин, так и из женшин}

Ключевые слова: графический дизайн, верстка, дизайн, графическое оформление журнала, особенности верстки периодических журналов, профессиональная подготовка будущих дизайнеров, педагогика, учебный процесс

\section{Марченко Марина Николаевна}

Доктор педагогических наук, профессор, зав. кафедрой

Кубанский государственный университет г. Краснодар, ул. Ставропольская, 149

\section{Гвоздева Алена Павловна}

\section{Магистрант}

Кубанский государственный университет

г. Краснодар, ул. Ставропольская, 149
This article describes the main challenges in today's market of periodicals in the field of cooking. The authors investigated the specificity of design of culinary magazines and proposed the solution of the problem by developing a new edition that would meet the needs of a broad focus groups consisting of both male and female

Key words: graphic design, layout, design, graphic design of a magazine, layout features of periodicals, training future designers, pedagogy, educational process

\author{
Marchenko Marina Nikolaevna \\ Doctor of Pedagogic Sciences, Professor, head of \\ Department \\ Kuban State University \\ Krasnodar, Stavropolskaya st., 149
}

\author{
Gvozdeva Alena Pavlovna \\ Undergraduate \\ Kuban State University \\ Krasnodar, Stavropolskaya st., 149
}

На современном рынке существует масса различных периодических изданий. Все они имеют различную направленность. Одни помогают повысить уровень знаний, другие - скрасить серые будни. Такой широкий ассортимент может утолить потребности в получении информации у детей и взрослых. Например, сейчас с легкостью можно купить кулинарный журнал, в котором хозяйка любого возраста может найти для себя массу полезных идей и необычных рецептов.

В данной статье предоставлен подробный анализ рынка определенного сегмента периодических изданий, выявлены проблемы и предоставлены пути решения. Результаты проведенного исследования можно использовать в про- 
цессе профессиональной подготовки будущих графических дизайнеров в вузах. Данный материал позволит ознакомиться с ассортиментом периодических изданий, а также с основными особенностями верстки и графического оформления.

Часто современные кулинарные журналы пестрят качественными, яркими фотографиями блюд, продуктов, полезной утвари. Женщины-покупатели склонны остановиться, разглядеть мелкие подробности, полистать и в итоге купить его из-за огромного количества информации, которая путает мысли и сбивает с цели. Казалось бы, обилие информации - огромный плюс в современных периодических изданиях, ведь это привлекает, иногда даже заставляет их приобрести. Однако основной проблемой является именно то, что они могут привлечь по большей части женщин, и редкий мужчина заинтересуется этими пестрыми картинками. Ведь, как известно, мужчины склонны совершать покупки, не думая о цене или какой-то яркой индивидуальности товара. Простота и доступность - вот что в первую очередь привлечёт внимание мужчиныпокупателя.

Практически для всех кулинарных журналов, которые мы исследовали, не предусматривается их приобретение мужчиной-покупателем. Возможно, это происходит потому, что существует некий стереотип о том, что приготовление пищи, в основном, женское занятие. А ведь если посмотреть на этот вопрос здраво, то все лучшие повара - мужчины. Ритм жизни существенно изменился, различия деятельности по гендерному признаку утратили свою актуальность. Следует отметить, что пренебрежение мужской аудиторией - это не единственный минус современных кулинарных изданий. Эти журналы переполнены нетематической рекламой, которая зачастую мешает восприятию читателем их содержания.

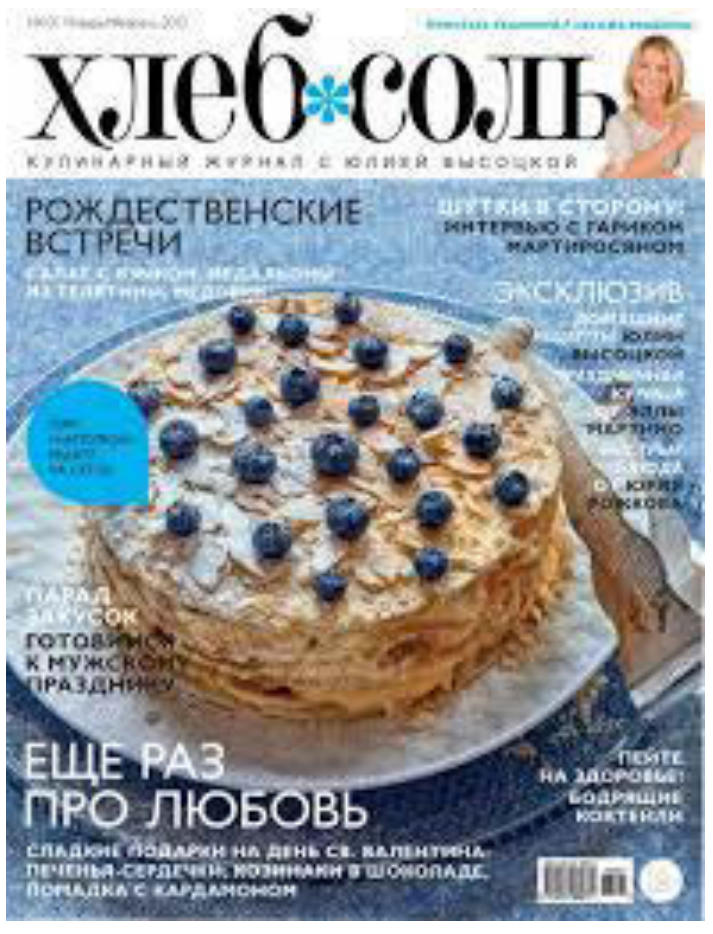

Рис. 1. Обложки журнала Хлеб соль 
Итак, следует остановиться подробнее на некоторых аналогах. Первый пример - журнал «Хлеб Соль», который сейчас является одним из самых популярных (рис. 1).

Известность он получил благодаря его создательнице Юлии Высоцкой, ведущей телепередачи «Готовим дома». Данный журнал выходит с периодичностью один раз в месяц, под слоганом «простые решения - легкие рецепты». 0 его простоте говорит лаконичный логотип, автором которого является Кожухова Катерина, член секции «Промграфика» Союза художников Москвы. Обладательница награды 1998 г. - биеннале «Золотая Пчела 4» в номинации «журнальный дизайн». Автор концепции Анна Людковская утверждает, что полезная пища может быть вкусной. Данный журнал направлен на ознакомление русских хозяек с зарубежной культурой кулинарного искусства. В целом журнал вызывает положительное впечатление, за исключением некоторых нюансов. Стоит немного остановить внимание на них. Начнем с того, что данное издание имеет сложную структурную рубрикацию. Это затрудняет восприятие и возможность легко и просто найти необходимую информацию. Хотя есть и своя неповторимость: всегда присутствует раздел «сезон», где, учитывая особенности того или иного сезона, предложены рецепты. Также есть две рубрики, которые неизменны из номера в номер: «хлеб» и «соль». Журнал переполнен яркими фотографиями, условными значениями «навигации» и, конечно же, рекламой. С точки зрения информативности данное издание неплохо преуспело. Хотя огромное количество рекламы не по теме вызывает спорные чувства. Далее хотелось бы сказать об обложке: на обложку данного периодического издания всегда помещается фото главного блюда сезона. Такое изображение имеет свойственный для того или иного времени года колорит.

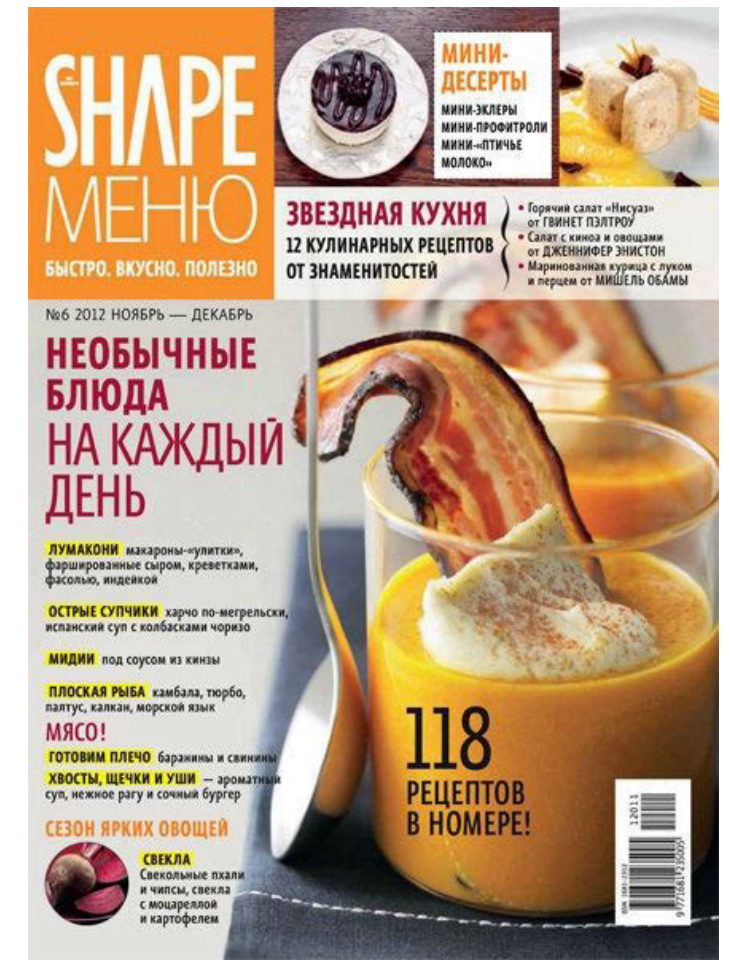

Pис. 2. Обложки журнала "Shape меню" 
Фотографии всегда очень яркие и качественные, но, опять же, на них представлено столько информации, что зритель не улавливает того посыла, который пытается донести дизайнер, и его внимание быстро рассеивается.

Также среди аналогов на рынке стоит отметить и такой журнал как "Shape меню", который выходит под слоганом: "Быстро. Вкусно. Полезно". Этот журнал впервые вышел в Америке, но сейчас уже выпускается во многих странах, в частности, в России (рис.2).

Дизайнером русифицированной версии журнала является Наталья Василевская. Если говорить о концепции данного издания, то оно позиционирует себя как маленький справочник простых и невероятно вкусных рецептов, которые идеально подойдут к семейному ужину. Это понятно и по слогану, о котором упоминалось выше. Далее стоит дать оценку дизайну издания в общих чертах. Итак, логотип прост и узнаваем за счет своей ярко оранжевой плашки. И цвет плашки, и место положения логотипа остается неизменным из номера в номер. Снова неприемлемое количество информации на обложке, из-за которого даже сложно разглядеть само фото блюда. Внутри данное издание переполнено информацией. Рубрикация проще, чем у предыдущего аналога, но все еще сложна для быстрого восприятия, потому что текст разорван неуместными изобразительными элементами. Эта созданная в содержании путаница прослеживается всюду. Сбивают с толку линейные отбивки и слишком большой наборной шрифт. Но самой главной проблемой является несоответствие заявленной концепции. Ведь в журнале говорится о простоте, а предложенные блюда порой состоят из таких ингредиентов, которые при огромном желании найти не в столичном городе будет практически невозможно.

Анализируя данные примеры можно проследить одни и те же минусы: это большое количество нетематической, через чур яркой рекламы, достаточно избитым и не отличающимся оригинальностью дизайнерским решением.

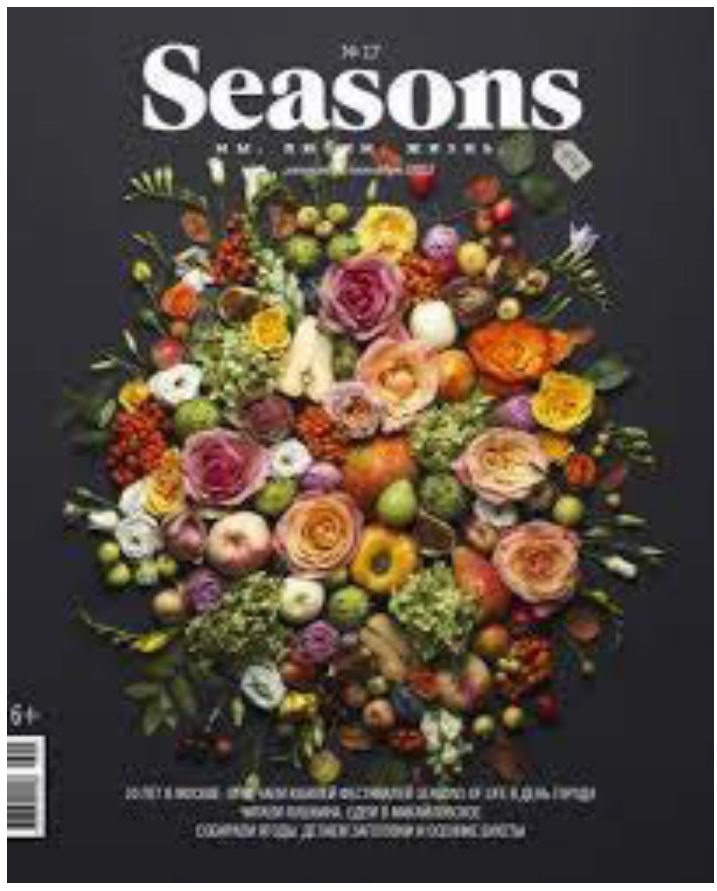

Pис. 3. Пример обложки журнала "Seasons of life" 
Поэтому решено было обратиться не только к кулинарным журналам, но и к тем, что имеют более широкий профиль. Самым удачным журналом для женщин, где написано все и обо всем, можно считать журнал "Seasons of life" (рис.3).

Во-первых, данное издание притягивает внимание за счет простоты обложки, где присутствует одно яркое, выделяющееся пятно на светлом фоне. Автор обложек Настя Слепцова не боится использовать белый фон с акцидентными пятнами. Из номера в номер меняется стилистика: иногда в основе прекрасные фотографии, иногда аппликации, а иногда и вовсе рисунки. В целом такие кардинальные отличия в графике и цвете можно принять как положительный момент, но это зачастую ставит покупателя в тупиковую ситуацию и затрудняет возможность идентификации издания. Логотип Seasons очень лаконичен и выполнен с типичным сдержанным британским консерватизмом, само слово удобочитаемо, но маленькая бирка на букве «S» с продолжением «of life» сложна для быстрого восприятия. В данном периодическом издании также хорошо внедрена реклама. Все рекламные сообщения не перегружены цветом и текстом, не раздражают, и, самое главное, не мешают восприятию нужной тематической информации.

Проанализировав некоторые примеры с конкретной направленностью, можно с уверенностью сделать вывод о том, что в наше время редакторы уделяют гораздо больше внимания внешнему виду издания, здесь имеет значение бумага, формат, дизайн. В первую очередь необходимо позаботиться о том, чтобы издание было приятно взять в руки, ведь восприятие читателем любого издания начинается с оценки его внешнего облика - прежде чем читатель станет вчитываться в текст, его внимание будет привлечено оформлением [5]. Прилавки с периодическими изданиями пестрят красками, как раз для того чтобы привлечь внимание, но их такое огромное количество, что все они сливаются в одно яркое пятно, из которого вычленить что-либо становится просто невозможно. Например, часто кулинарные журналы, которые мы рассматривали выше, для оформления своей обложки предпочитают выбирать «вкусное» фото какого-либо блюда. Раньше это было бы достаточно удачным ходом, но не сейчас, когда каждое второе такое издание избирает для себя идентичную концепцию стилистического решения. И хотя редакторы понимают необходимость хорошего дизайна, единого мнения по данному вопросу пока не существует. Одни считают, что хороший дизайн подразумевает обилие графики и активного использования цвета, другие - что хороший дизайн должен быть максимально функционален и обращаться с иллюстрациями и цветом следует осторожно. Так, анализ нынешнего рынка периодических изданий в области кулинарии привел к выводу, что современному ассортименту не хватает некоего универсального продукта. Который не позиционировал бы себя как «женский журнал кулинарии», был бы легок в использовании за счет своего формата и рубрикации, предоставлял доступные рецепты изысканных блюд и отличался бы от других за счет необычного дизайна.

Итак, новое разрабатываемое издание будет называться «Кулинарные зарисовки» - журнал, который с легкостью научит любого приготовлению са- 
мых разных блюд. Фокус-группа будет довольно широкой, в нее будут входить как мужчины, так и женщины от 30 до 50 лет. Это значительно усложнит задачу дизайнерского оформления, но позволит привлечь большее количество читателей. Ведь нужно учитывать, что в современном мире покупают кулинарные журналы не только женщины, но и мужчины. Мужчины стали гораздо больше ходить по магазинам. Эта тенденция будет наблюдаться и дальше. Поскольку они все дольше остаются холостыми, им приходится учиться покупать те вещи, о которых их отцы никогда не заботились. Учитывая также то, что мужчины женятся на женщинах, которые много и упорно работают, они будут вынуждены брать на свои плечи все большую часть забот [2].

Чтобы продукт привлекал всех, независимо от половой принадлежности, в первую очередь должен быть правильное дизайнерское решение. Буквы логотипа вписываются в вертикальный прямоугольник, не имеют засечек. Шрифты этого семейства являются акцидентными, в отличие от антиквы, именно поэтому начертание логотипа соответствует канонам гротескных шрифтов. Логотип довольно прост, чтобы соответствовать общему слогану журнала: «Все самое лучшее просто». Облегченное начертание букв украшает и обогащает небольшой нарисованный элемент (рис.4).

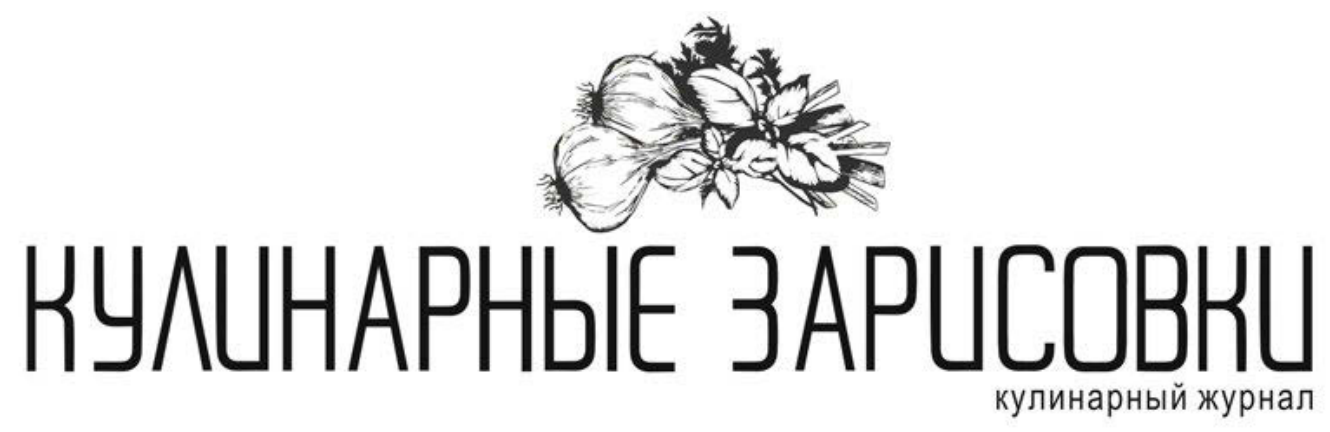

Рис. 4. Логотип разрабатываемого издания

Исходя из названия журнала «Кулинарные зарисовки», главными графическими элементами первого выпуска были выбраны нарисованные фрукты, овощи и другие продукты. Это было сделано для того, чтобы закрепить связь образа и названия в сознание потребителя. Сами графические элементы не навязчивы и довольно лаконичны. Плюс к нарисованным элементам добавятся геометричные, но не слишком навязчивые плашки и отбивки. Это позволит приобрести данному изданию некую жесткость и мужественность, но при этом не потерять мягкость и уют, за счет нарисованных элементов (рис.5).

Зачастую дизайнеры журналов усложняют структуру издания, это отталкивает многих потребителей. Но также слишком простой журнал не будет пользоваться большим спросом. Значит, при разработке дизайна журнала следует искать нечто среднее между сложностью и простотой. Что-то упростить, а что-то другое сделать немного сложнее. Внутренне графическое содержание не будет пестрить излишним цветом и информацией, простая рубрикация значительно облегчит процесс эксплуатации (рис.6). 


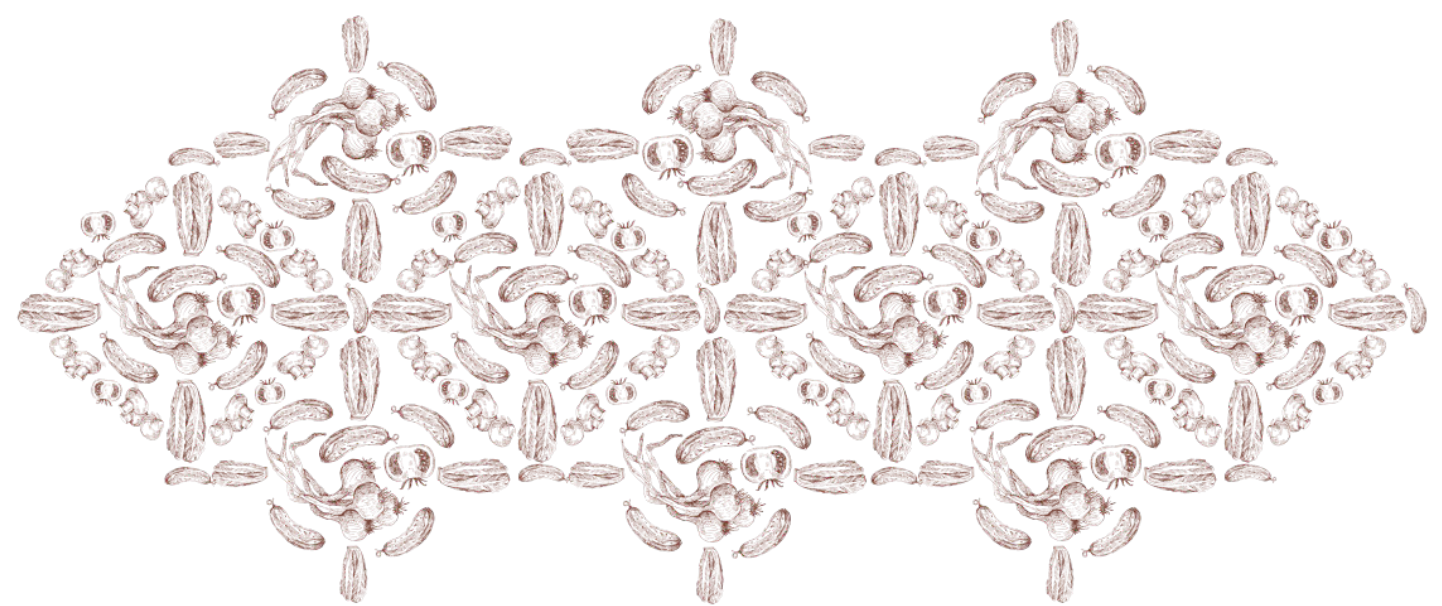

Рис. 5. Графические элементы

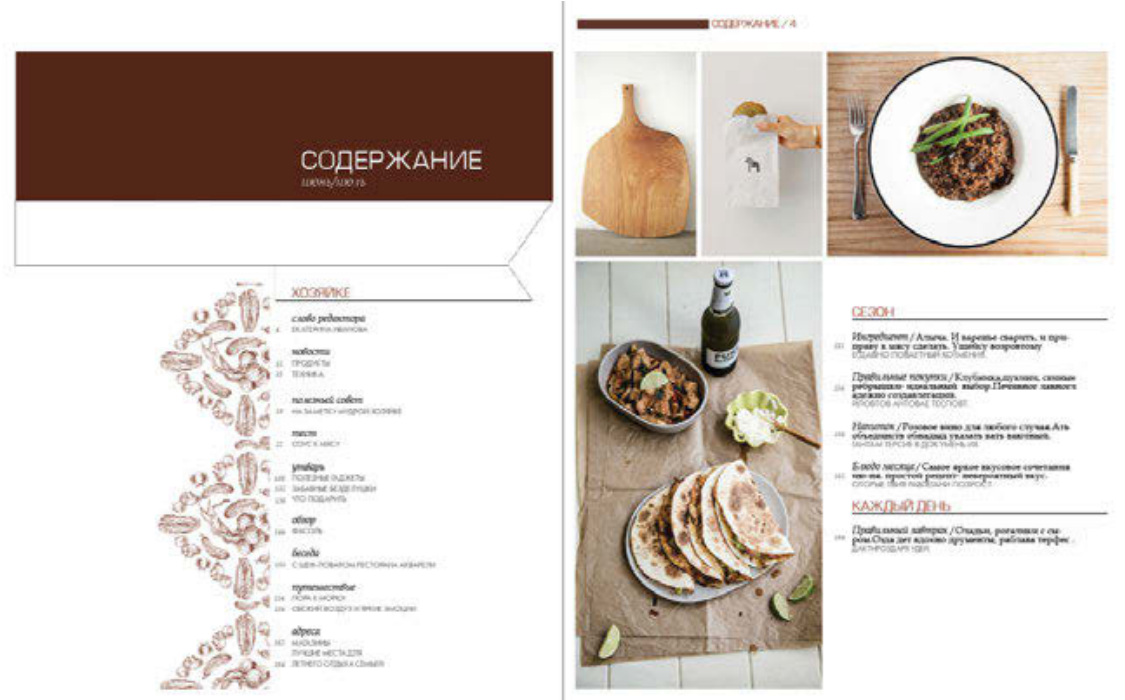

Рис. 6. Пример разворота с содержанием

Далее речь пойдет о подборе цветового решения. В ходе многочисленных психологических экспериментов ученые пришли к выводу, что цвет определенным образом влияет на восприятие человеком конкретного предмета. В зависимости от настроения одни цвета могут быть человеку приятны, а другие могут его раздражать. А так как цвет воздействует на чувства, а не на разум человека, нужно быть очень внимательным при выборе цветового решения любой полиграфической продукции [3]. Цвета, использующиеся в данном выпуске, будут как теплые, так и холодные. Например, темно-коричневый и бежевый цвета. Психология восприятия коричневого цвета такова: он «заземляет». Цвет земли и древесных стволов будит воспоминания о камине и доме, а потому связан с представлениями о комфорте. Коричневый цвет облегчает выбор, так как считается вневременным, а также свидетельствуют об экологической чистоте [4]. А вот бежевый цвет - это всегда актуальная классика. Достаточно сложный цвет, способен успокаивать, обладает теплой, тихой и спокойной энергетикой. Бежевый цвет считается также достаточно несамостоятельным, фоновым. За счет этих цветов можно создать приятную «домашнюю» атмосфе- 
ру, которая привлечет представителя заданной фокус-группы, независимо от его гендерной принадлежности.

Одним из достоинств журнала, отличающих его от других, конкурирующих изданий, будет отказ от использования фотографии на обложке. «Лицо» данного издания будет выглядеть светлей и приятней за счет нарисованных овощей и, сложенного их них авторского паттерна. Далее хотелось бы сказать и о рекламе. Не секрет, что основным источником доходов для владельцев коммерческих периодических изданий является реклама [5]. Поэтому от рекламы избавиться полностью не удастся. Есть два выхода: либо свести рекламу к минимуму, либо проработать так, чтобы она идеально вписывалась в журнал по стилю и теме. Второй вариант значительно лучше. В данном периодическом издании будет использоваться необходимое количество рекламы, но вся она будет строго тематической и вписанной в общий вид разворотов по стилистическим параметрам. Под тематической подразумевается такая реклама, которая не отходила бы далеко от темы приготовления пищи: гипермаркеты, рестораны, бары, кафе, различные курсы и кулинарные школы. В первую очередь все должно быть гармонично. Будь это нечто нарисованное или сфотографированное - общая ассоциативная цепь, которая так важна для формирования образа журнала, должна присутствовать во всем.

Если говорить о перспективе развития данного издания, то стоит немного рассказать также и об оформлении последующих выпусков. Ни для кого не секрет, что сейчас очень ценится вариативный дизайн, а большая часть предлагаемого ассортимента на рынке периодических изданий не пользуется вариативностью. На этом и можно сыграть, вводя некоторые изменения в стиль каждого номера. Пользуясь такой тактикой, важно не переусердствовать с новшествами и не утратить общий узнаваемый вид продукта. Например, в первом номере можно использовать авторский паттерн из нарисованных овощей, а во втором - построенный по той же сетке, но уже сфотографированный паттерн. Таким образом, появится вариативность, но узнаваемость, безусловно, останется.

Выпуск периодического издания - непростая задача. Можно сказать, что хороший дизайн, применительно к периодическим изданиям - это грамотная и осознанная компоновка текста с визуальными элементами, благодаря которой можно достичь успеха. Хорошо выполненный дизайн способствует более легкому чтению и пониманию. У читателей нет ни времени, ни терпения преодолевать дизайнерские ухищрения для извлечения информации. Дизайн периодического издания должен быть достаточно гибким, чтобы присутствовал элемент сюрприза [5].

\section{Список литературы:}

1. Ажгихин С.Г. Содержание профессиональных компетенций будущих дизайнеров с учетом регионального аспекта // Преподаватель ХХІ век. 2011. Т. 1. № 1. С. 12-18.

2. Андерхилл П. Как покупают мужчины и женщины Журнал // Элитариум портал дистанционного образования, 2005. URL: http://www.elitarium.ru/

3. Дубинин Н. Размышления о цвете // КомпьюАрт. 2011. № 11. URL: http://www.compuart.ru/

4. Иттен И. Искусство цвета. СПб., 2001. 
5. Кнабе Г.А. Энциклопедия дизайнера печатной продукции. Профессиональная работа. М., 2006. 6. Марченко М.Н. Влияние дизайнерской деятельности на развитие способностей обучающихся к творчеству // Международный журнал экспериментального образования 2013. № 11-3. С. 201-203. 7. Рудер Э. Типографика. Руководство по оформлению. М.,1982.

8. Чихольд Я. Новая вёрстка. М., 2011.

\section{References:}

1. Azhgikhina S.G. Contents professional competencies of future designers taking into account the regional dimension // Teacher XXI century. 2011. Vol. 1. № 1. Pp. 12-18.

2. Underhill P. How to buy men and women magazine // Portal Elitarium distance education. 2005.

URL: http://www.elitarium.ru/

3. Dubinin N. Reflections on the color // KompyuArt. 2011. № 11. URL: http://www.compuart.ru/

4. Itten I. The art of color. SPb., 2001.

5. Knabe G.A. Encyclopedia designer of printed products. Professional work. M., 2006.

6. Marchenko M.N. Influence of design activities for the development of abilities of students to be creative // International Journal of Experimental Education. 2013. № 11-3. Pp. 201-203.

7. Ruder E. Typography. Style guide. M., 1982.

8. Tschichold J. New layout. M., 2011.

(C) 2014, Марченко М.Н., Гвоздева А.П.

Графическое оформление современного

кулинарного журнала
(C) 2014, Marchenko M.N., Gvozdeva A.P. Graphic design of a modern cooking magazine 


\title{
Красновский В.Н., Баловнева Я.В., Басотина О.М., Кутузов Е.Л., Моруженко Н.А. Изучение самосознания подростков мужского пола, поступающих в высшие военные учебные заведения Министерства обороны Российской Федерации
}

\author{
Krasnovsky V.N., Balovneva Y.V., \\ Basotina O.M., Kutuzov E.L., Moruzenko N.A. \\ The study of self male adolescents coming in higher military \\ educational institutions of the Ministry of defense \\ of the Russian Federation
}

В статье идет речь об опыте, который получает подросток выпускник в социальном пространстве современного общества. Самосознание является своего рода социально - архитектурной логикой опыта. Именно ему подростающая личность обязана овладением сложными феноменами общества. Показателем успешной социальной ориентации выступает социализация - важный и точный индикатор подростковой зрелости. Процесс социального самосознания личностного развития подростка, должен быть аксеологично объективированным и ориентированным на ценности, которые будут определять характер жизнедеятельности подротающей личности

ключевые слова: сознание, самосознание, социализация, подростковый возраст, субкультура, ценности, оценка, молодежная среда, моральные убеждения

Красновский Валерий Николаевич

Кандидат психологических наук, доцент

Военно-космическая академия им. А.Ф. Можайского г. Санкт-Петербург, Ждановская ул., 13

\section{Баловнева Яна Владиславовна}

Преподаватель

Военно-космическая академия им. А.Ф. Можайского 2. Санкт-Петербург, Ждановская ул., 13
In the article talking about the experience which receives a teenager graduate in social space of modern society. Consciousness is a kind of socio architectural logic of experience. It was he podrostayushee the person is obliged mastering complex phenomena of society. The rate of successful social orientation is socialization is an important and accurate indicator of adolescent maturity. The process of social self-awareness of personality development of the adolescent should be Axiologic objectified and focused on the values that will determine the nature of life potatoesa personality

Key words: consciousness, identity, socialization, adolescent age, subculture, values, assessment, youth medium, moral beliefs

Krasnovsky Valery Nikolaevich

Candidate of Psychological Sciences, associate Professor

Military space Academy Alexander Mozhaisky St. Petersburg, Zhdanovskaya st., 13

\section{Balovneva Yana Vladislavovna \\ Teacher}

Military space Academy Alexander Mozhaisky St. Petersburg, Zhdanovskaya str., 13 


\section{Басотина Ольга Михайловна}

Преподаватель

Военно-космическая академия им. А.Ф. Можайского

2. Санкт-Петербург, Ждановская ул., 13

\section{Кутузов Евгений Леонидович}

Преподаватель

Военно-космическая академия им. А.Ф. Можайского

2. Санкт-Петербург, Ждановская ул., 13

\section{Моруженко Николай Анатольевич}

Кандидат психологических наук, профессор

Военно-космическая академия им. А.Ф. Можайского

г. Санкт-Петербург, Ждановская ул., 13

\section{Basotina Olga Michailovna}

Teacher

Military space Academy Alexander Mozhaisky

St. Petersburg, Zhdanovskaya str., 13

\section{Kutuzov Evgeny Leonidovich}

Teacher

Military space Academy Alexander Mozhaisky

St. Petersburg, Zhdanovskaya str., 13

\section{Moruzenko Nikolay Anatolievich}

Candidate of Psychological Sciences, associate Professor

Military space Academy Alexander Mozhaisky St. Petersburg, Zhdanovskaya str., 13

\section{Введение}

Сегодня можно выделить целый ряд проблем с точки зрения понимаемого смысла термина «самосознание». Эти проблемы нарастают не только в теории, а и структуре, функциях, изучении сознательных форм активности самосознания (А.Ю. Агафонов, В.М. Аллахвердов, О.Е. Иванов, М.К. Мамардашвили и другие). Психологические концепции признают самосознание сложным психическим процессом, поэтому данное явление имеет устойчивую актуальность, поскольку затрагивает человека в личном рассмотрении реальности, как индивидуального субъекта [11]. Когнитивные процессы понимания, переросшие в самосознание, закрепились за человеком в социальной общности. Он, осознавая свою самость, научился самостоятельно противопоставлять ей свою индивидуальность. А. Агафонов соотносит самосознание как «понимающее себя сознание», отмечая, что факты сознания могут дифференцироваться « на осознаваемые и неосознаваемые явления» [1, с.15]. По этому поводу Л. Коростылева замечает, что реализация когнитивного, поведенческого, регулятивного проявлений смысла в человеке усложняется проблемой сочетания внутренних стимулов и внешних условий саморазвития [8]. С точки зрения всех существенных особенностей человека, они не эксплицируемые явления. Степень их проявлений в разных ситуациях обнаруживает себя индивидуально через сенсорно-перцептивный, линию представления, мыслительный и рефлексивный опыт. Рассматривая динамику этих содержащих смыслы процессов, авторы сознательно не стали анализировать познавательную деятельность подростка, а ограничились раскрытием опыта социального самосознания подростка.

Основная часть.

Юность является периодом «нормативного кризиса» для, которого характерны колебания силы «Я» и усиленное проявление конфликтов. В то же время подростковый возраст сопровождается динамичным психосоциальным процессом, который участвует в индивидуальном пути развития личности процессом персонализации ее действий. Из-за этого, в своем большинстве, подростки пытаются обойти влияния взрослых, уходят от социальной активности, а иногда, наоборот, чрезмерно вовлечены в нее, поддавшись групповому 
влиянию, что делает психологическую ситуацию для подростка противоречивой и конфликтной. Возникшие между индивидуальной самостоятельностью и опекой взрослых усложнения, подросток поддерживает в субкультуре. В этом случае подростковая субкультура выступает не столько гарантом культурной идентичности, сколько необходимым модификатором между социальными отношениями. За счет “культурной” поддержки подростки вырабатывают к действующим социальным структурам личное понимание. Психологическими барьерами могут стать правила, традиции, групповые нормы, иначе говоря, маркированный тип отношений. Если среда агрессивна и подросток в ней, демонстрирует ригидность своего самосознания - это усиливает ее «когнитивные» вмешательства [9].

В этот период подростку важно сформировать чувство идентичности. Так он может избежать опасности возникновения ролевой и идентификационной диффузии (спутанной идентичности) [5]. Здесь важно достичь самоидентичности, проверить относительно себя правильность социально-ролевого поведения, четко определить свои стандарты и выбор будущего пути. Отсутствие такой четкости у подростка может привести и, чаще всего приводит, к разрушающей односторонней деятельности. Он, скорее всего, будет болезненно реагировать на замечания окружающих или, наоборот, игнорировать их внимание. Подобная ролевая диффузия повышает тревожность подростка в социальном пространстве. Она также может служить причиной его замкнутости и способствовать пристрастию к алкоголю и наркотикам[16]. Формирование негативной идентичности тесно связано с включением подростка в девиацию [7] или субкультуру.

Взросление подростка стимулирует общественная работа. Она формирует его гражданскую позицию, понимание чувства социальной ответственности, оттачивает «образцы» социально-компетентного поведения в результате чего начинается его действительная интеграция с обществом [13]. В этом ему помогает индивидуальная цель, программа роста, которая в налаживании социальных связях совпадает с индивидуальной мотивацией.

Наши исследования показывают, что в референтной группе личностные отношения в подростковой среде складываются от принятой в ней субкультурной символики. Этим символическим капиталом подросток пользуется, осваивая свое жизненное пространство. Целенаправленная активность, самоутверждение, самоопределение, проявляемые на разных уровнях познавательной практики и общения помогает ему строить социально-ролевую модель поведения. Такую модель можно представить как континуум альтернатив, которые колеблется в границах пассивных до активных, лидерских, творческих видов деятельности.

Роль воспитания здесь может сыграть ведущую роль, если учитывать возросшие возможности подростка. Такой путь развития приводит к самореализующейся социализации. Он способствует осмыслить личный опыт: рефлексия становится основой сознания подростка [2].

Райс Ф. обнаружил, что подростки с высокими показателями формального мышления присваивали более высокий рейтинг ценностям инструменталь- 
ного характера, особенно уверенности в себе, компетентности, независимости. Подростки с низкими показателями формального мышления оказывали предпочтение группам ценностей личностного характера, которые связывали мгновенной наградой и общественным одобрением [13].

Подросток чувствует себя участником жизни своего сообщества только тогда, когда его цели ориентированные на взаимоотношения со средой. Таких подростков характеризует стойкий личностный интерес ко всему новому, целенаправленная воля в овладении знаниями и социальными практиками. Их можно отнести к группе молодежи с высокой социальной компетентностью. Они хорошо адаптированы к социальному пространству, то есть адекватно социализированные. Об этом можно судить по продуктам их индивидуально творческой деятельности, которая направлена на социальную продуктивность. Реализуя значимую цель, достичь стойких, позитивных результатов своей деятельности, эти подростки развивают и усовершенствуют социальные взаимосвязи и программы личного роста. Менее адаптированные к социальным изменениям подростки, наоборот, чувствуют себя неуверенно в молодежной среде, поскольку относятся к ней как конформисты. Выбор ригидной стратегии таких юношей связан с нарушением социализации подростка [6]. В результате подросток ищет способы достижения своих целей там, где они менее конфликтны, в среде таких же сверстников, как и он сам [12].

Подросток усваивает моральные императивы, традиции, социальные нормы окружающего его общества, являясь носителем сознания. Самосознание само социально, оно предполагает в качестве важного условия существования опыт осознания когнитивных механизмов, которые позволяют отражать социальные процессы и самоопределяться в социуме [14].

Учитывая вышеизложенное, мы провели исследование подростков призывного возраста, которые выбрали профессию военного. В исследовании приняло участие 30 юношей учащихся школ Петроградского района города Санкт-Петербурга общеобразовательная школа №9 и 30 юношей того же района города Санкт-Петербурга - колледж №70. Исследование проводилось в выше указанных учебных заведениях в дневное время на классных часах. Материал опросников предлагался в устном виде, фиксация проводилась респондентом самостоятельно. В проводимом исследовании был охарактеризован подростковый возраст в условиях нестабильного социума, определены особенности самосознания и самоотношения подростков, выбравших профессию офицера с разной социально-культурной подготовкой.

Для получения первичного материала было проведено экспериментально-психологическое исследование, включающие следующие методики: тестопросник самоотношения (ОСО) (В.В. Столина, С.Р. Пантелеева), тест самоактуализации (САТ), методика « Не-Я» (автор А.В. Визгина), шкала самоуважения М. Розенберга, тест 20 утверждений на самоотношение М. Куна, Т. Макпарленда, сочинение «Мой мир».

В настоящем исследовании проведен сравнительный анализ самосознания подростков с разной культурной подготовкой и социальным статусом, выбравших профессию офицера. Установлен факт, что самоотношение подрост- 
ков в зависимости от их статуса действительно различаются. Была установлена взаимосвязь социального статуса и поведения подростков. Полученные результаты можно использовать в коррекционной и воспитательной работе с будущими курсантами. Данное исследование затрагивает и проблему актуальную в настоящее время - неуставные отношения.

При обработке данных методом математико-статистической обработки, а именно, анализа корреляционных матриц и дисперсионного анализа, были обнаружены значимые различия между подростками, характеризующимися низкой культурной подготовкой и недостаточно значимым статусом, и подростками, характеризующимися высокой подготовкой и значимым социальным статусом. Их выбор отличался количеством позитивных выборов.

По результатам статистической обработки данных по методике исследования самоотношения В.В. Столина, С.Р. Пантелеева при помощи многофакторного ANOVA обнаружено статистически значимое $(\mathrm{p}<0,05)$ совокупное влияние факторов низкого и высокого статуса на величину показателей по шкалам: закрытость, самоуверенность, саморуководство, отраженное самоотношение, самоценность, самопринятие, самопривязанность, внутренняя конфликтность, самообвинение (таблица 1).

Таблица 1. Результаты статистической обработки по методике исследования самоотношения В.В. Столина, С.Р. Пантелеева

\begin{tabular}{|l|c|c|}
\hline \multicolumn{1}{|c|}{ Шкала } & $\begin{array}{c}\text { Низкий статус } \\
\text { учащиеся } \\
\text { (колледж № 70) }\end{array}$ & $\begin{array}{c}\text { Высокий статус } \\
\text { ученики общеобразова- } \\
\text { тельной школы № 9 }\end{array}$ \\
\hline Закрытость & 7,3548 & 5,3548 \\
\hline Самоуверенность & 7,7895 & 6,3548 \\
\hline Саморуководство & 2,5123 & 7,8182 \\
\hline Отраженное самоотношение & 3,1935 & 5,6842 \\
\hline Самоценность & 1,4737 & 5,7419 \\
\hline Самопринятие & 3,7419 & 7,4211 \\
\hline Самопривязанность & 7,9644 & 4,8937 \\
\hline Внутренняя конфликтность & 7,6745 & 4,1025 \\
\hline Самообвинение & 6,7342 & 3,7324 \\
\hline
\end{tabular}

Эти данные можно интерпретировать следующим образом: закрытость, больше выражена у подростков с низким социальным статусом, как и низкая оценка своего подхода к саморуководству, отраженному самоотношению, личной самоценности. Это повышает у данных подростков внутреннюю конфликтность и самообвинение в проблемных ситуациях или не решенных проблемах, понижает личное самопринятие, которые компенсируются за счет самоуверенности и самопривязанности к какому-либо предмету или увлечению. Для подростков с высоким социальным статусом характерны проявления таких качеств как саморуководство, самопринятие, самоуверенность. Закрытость для данной группы подростков вызвана не экологически настроенной среды по отношению к их будущему, подкрепляющих их мировосприятие и социальное поведение. Факторная структура Я - концепции включает в себя ценности 
«собственного престижа», «креативность», «активные социальные контакты». Это характеризует подростков с высоким социальным статусом как стремление к престижу и статусу на что указывает высокие показатели шкал саморуководство, самопринятие, самоуверенность. Такие переменные, как: внутренняя конфликтность, самообвинение, самопривязанность для данной группы подростков призывного возраста не столь значительна, поскольку они нацелены на профессиональную компетенцию и на полюс самооценки собственной активности. Это свидетельствует об их пассивности к формам воспитательной работы предлагаемые учебным заведением и спокойных эмоциональных реакциях на окружение, что подкреплено их высоким социальным статусом. Они достаточно критичны к школьному консерватизму и стремятся развивать в себе творческие задатки. Их положение и статус в контексте общественной жизни имеет тенденцию «БЫТЬ». Для подростков с низким социальным статусом в контексте общественной жизни имеет тенденцию «иметь». С этой точки зрения данные подростки, в виду своего статуса, гиперкомпенсируют свою недоступность к росту, развитию, реализации своих способностей и талантов.

Подростки с низким социальным статусом показали и невысокие позитивные выборы по предлагаемым им тестам. Они показали так же высокие показатели по количеству негативных выборов, то есть такие подростки плохо приживаются в социальной среде и чаще отвергаются как в семье, так и в учебном заведении. В целом, для них больше представляется зависимопослушный тип поведения, желание соответствовать норме и выступает она как приспособление для создания личностного комфорта. Для данной группы характерно выявление личной идентичности и меньшей степени социальной идентичности. У подростков с высоким социальным статусом выражена актуализированная социальная идентичность. Они менее демонстративны, чем подростки с низким социальным статусом.

Показатели удовлетворенности отношениями, а также отношение к себе связано с личностными особенностями подростков. Меньше бояться быть отвергнутыми юноши, имеющие более высокий статус. Им свойственна независимость, эмоциональная устойчивость, общительность, количество продуманных контактов. Подростки с низким социальным статусом выражают страх отвержения, имею беспорядочные контакты, полюс отношений противоречивый и напряженный.

На основания корреляционной матрицы в группе подростков с высоким социальным статусом выявлено много позитивных выборов по предлагаемым методикам, которые обнаружили следующие корреляционные связи. Количество позитивных выборов (КПВ) положительно взаимосвязано с показателями «физическая идентичность»и «удовлетворенность собой». Физическая идентичность отрицательно взаимосвязана с саморазрушающими тенденциями, удовлетворенность - с проблемной идентичностью. Последние взаимосвязаны между собой. Другими словами, если подросток не уверен в себе, у него могут сформироваться саморазрушающиеся тенденции. Но мы рассматриваем группу подростков с высоким социальным статусом и к тому же с высоким количеством позитивных выборов, а значит данные подростки довольны собой, своей 
жизнью в целом, а так же у них хорошо выражена физическая идентичность, что говорит нам о том, что у данных подростков снижен риск формирования саморазрушающих тенденций в поведении и формировании проблемной идентичности. Уверенные в себе подростки с высоким социальным статусом популярны, используют прямолинейно-агрессивный тип поведения, который ярко проявляется в творческом подходе в решении сложным и актуальных проблем. Соответственно, у данных подростков выражена не только физическая идентичность (большинство из них увлекается спортом), но социальная активность из-за уверенности в себе и успехами в учебно-социальной деятельности. Им свойственен и креативный акт поведения. У таких подростков снижен риск формирования саморазрушающих тенденций и проблемной идентичности.

Так же количество положительных выборов отрицательно взаимосвязано с показателями «трудности в общении» и «Интроверт», что в свою очередь положительно взаимосвязано с показателями «незащищенность». Иными словами, подростки, склонны к интроверсии, испытывают трудности и общении и прибегают к демонстративности в поведении, отрицательно сказывается на их популярности. Однако, мы рассматриваем подростков с высоким социальным статусом, показавшие высокие результаты количества позитивных выборов, а это значит рассматриваемые подростки не испытывают больших трудностей в общении, не испытывают чувства неполноценности и, в конечном итоге, не прибегают к демонстративности.

Возраст положительно взаимосвязан с интеллектом и групповой идентичностью. Таким образом, можно сказать, что подростки с высоким социальным статусом выше оценивают свои интеллектуальные способности, и больше склонны группироваться. Находясь в группе, данные подростки, характеризующиеся высокой популярностью, склонны к агрессии, враждебности, чтобы отстаивать свои лидерские качества. Данная агрессивность более всего выражена в организаторских умениях и захватить интересной информацией своих сверстников. Поэтому данные подростки могут выражать враждебность к тем сверстникам, которые могут противостоять им своими новыми идеями и увлечь за собой группу.

Красивый человек - уверенный в себе - не имеет проблем с общением (общительный, популярный). Для данной группы подростков характерна связь внешней привлекательности с общительностью и с уверенностью в себе. Чем привлекательнее внешне считает себя подросток, тем он более уверен в себе, и тем выше общительность, популярность среди сверстников.

Далее стоит отметить, что подростки в данной группе в основном, популярны среди сверстников, они не испытывают проблем в общении. Однако, если проблемы с общением все же появляются, скажем в снижении успеваемости по каким-либо предметам, увеличивается чувство неполноценности, что может привести, в конечном счете, к трудностям в общении. Это отрицательно сказывается на поведении в целом (поведение не соответствует требованиям взрослых), и даже может сформироваться зависимо-послушный тип поведения. То 
есть из агрессивного, активного лидера подросток может превратиться в комфортного, зависимого от мнения окружающих подростка.

На основания корреляционной матрицы в группе подростков с низким социальным статусом выявлено много низких позитивных выборов по предлагаемым методикам, которые обнаружили следующие корреляционные связи. Демонстративность выборов отрицательно взаимосвязана с самооценкой умственных способностей (ум), уровнем счастья и общей самооценкой. Показатели ума и счастья положительно взаимосвязаны между собой и самооценкой внешности. Исходя из этого, можно предположить, что демонстративность в поведении подростков с низким социальным статусом проявляется при низком уровне общей самооценки, низкой оценки своих умственных способностей и своей внешности, что в свою очередь влияет на уровень счастья. Таким образом, непопулярные подростки, имеющую низкую самооценку, низко оценивающие свою внешность и умственные способности, склонны к демонстративности. Чем ниже подросток оценивает свою внешность, тем больше у него возникает трудностей в общении, что в свою очередь взаимосвязано с саморазрушающими тенденциями и незащищенностью. Трудности в общении и восприятие своей внешности, наряду с оптимизмом и уверенностью в себе взаимосвязаны с проблемной идентичностью. То есть, подросток с низким социальным статусом склонен винить себя в своих проблемах, негативно о себе отзываться. Если он не уверен в себе, ему сложно общаться с окружающими. Он так же негативно относится к своей внешности и не считает себя оптимистом.

Оптимизм и счастье в свою очередь влияют на поведение подростка. Получается, что поведение подростка зависит от эмоционального состояния в данный момент. Суверенность территории положительно взаимосвязана с поведением, оптимизмом и уверенностью в себе. Уверенность в себе так же положительно взаимосвязана с общей самооценкой, которая, в свою очередь, отрицательна с тревожностью.

Тревожность отрицательно взаимосвязана с общением и с суверенностью социальных связей, которые между собой взаимодействуют положительно. С общением отрицательно взаимосвязана переменная коэффициент позитивных выборов и положительно властно-лидирующий стиль поведения. Низкая самооценка вызывает тревожность в общении со сверстниками, и может привести к властно-лидирующему типу поведения, который возможно повысит уверенность в себе и самооценку в целом. Таким образом, можно сделать вывод о том, что властно-лидирующий тип поведения у подростков с низким социальным статусом возникает вследствие низкой самооценки на фоне повышенной тревожности и проблем в общении со сверстниками с целью повысит уверенность в себе и самооценку в целом. Уверенность в себе имеет тесную взаимосвязь с оптимизмом, который в свою очередь тесно взаимосвязан с оценкой своего поведения. Все три показателя взаимосвязаны с суверенностью территории. Можно отметить, если подросток способен контролировать близость и количество социальных контактов, то свое поведение он оценит положительно, он будет более уверен в себе и более оптимистичен. Тогда вероятность развития проблемной идентичности будет снижена. 
Обобщая все вышесказанное, отметим, что у подростков с низким количеством позитивных выборов наблюдаются проблемы в общении со своими сверстниками и связанная с ними депривация социальных связей. Это приводит к повышенной тревожности и низкой самооценке. В итоге, подросток с низким социальным статусом выбирает властно-лидирующий тип поведения, который должен повысить уверенность в себе, самооценку, оптимизм. Трудности в общении связаны с незащищенностью подростка и могут привести к саморазрушающим тенденциям подростка (будь то девиантное поведение или депрессия). Так же трудности в общении подросток связывает с оценкой своей внешности, на фоне этого у подростка формируется проблемная идентичность. На низкую оценку внешности влияет, по всей видимости, низкая самооценка своих умственных способностей, что в совокупности снижает уровень счастья. Низкая самооценка своих интеллектуальных способностей, низкий уровень общей самооценки, и так же низкий уровень счастья приводит к демонстративности поведения.

Высокие позитивные выборы характеризуют подростков со значимым социальным статусом, а низкие позитивные выборы характеризуют подростков с недостаточно значимым социальным статусом.

Дисперсионный анализ и анализ корреляционных связей показали, что подростки с недостаточно значимым социальным статусом не только игнорируются, но и отвергаются в среде сверстников, а в социальной сфере находятся под вниманием взрослых из-за своей конформистской позиции.

Будучи отверженными, подростки с недостаточно высоким социальным статусом не способны удовлетворить потребность в общении, что приводит к депривации социальных связей и повышает уровень тревожности, что, в свою очередь, приводит к зависимо-послушному поведению, доходящему до сверхкомфортности.

Подростки с недостаточно значимым социальным статусом не просто не могут, но и не умеют строить общение со сверстниками. Эти подростки зависят от мнения окружающих, что приводит к конфликту: столкновение потребности в признании с отсутствием такового и с соответствующих навыков. Это противоречие может вызвать саморазрушающие тенденции.

Отверженность в группе, депривация социальных связей значительно снижают общую самооценку и приводят к формированию проблемной идентичности. Данные подростки склонны к самобичеванию, самообвинению и так далее.

Подростки с недостаточно значимым социальным статусом склонны к демонстративности, которая выражается в поведении не соответствующим требованиям взрослых, то есть в деструктивном поведении, что может служить компенсаторным механизмом в ответ на социальную депривацию и отверженность.

У подростков со значимым социальным статусом также может возникнуть демонстративность в поведении, однако она у них не связана с общительностью или популярностью. Подтвержден тот факт, что подростки с недостаточно значимым социальным статусом в целом более демонстративны, чем подростки с высоким социальным статусом. 
Подростки с высокой культурной подготовкой и значимым социальным статусом поддерживают свои лидерские позиции через проявление организаторских способностей и лидерских качеств в поведении и через творческую агрессивность и просто агрессивность, проявленной физической силой. При этом, для подростков с недостаточно значимым социальным статусом характерен акцент на власти и демонстративности.

Враждебность и агрессивность присутствует в поведении всех подростков независимо от статуса. У подростков с недостаточно значимым социальным статусом связано с заниженной самооценкой, с формированием проблемной идентичности и неудовлетворенностью своей жизненной ситуацией. Соответственно, враждебность проявляется как защитный механизм, попытка завуалировать, скрыть свои «проблемы», а у подростков с высокой культурной подготовкой и значимым социальным статусом, враждебность представляется, как реакция на депривацию социальных связей, что, в принципе, является характерной реакцией для подросткового возраста в целом.

Общим для всех подростков не зависимо от их социального статуса является то, что для достижения лидерства, популярности, принятия в среде своих сверстников, подростки в основном выбирают агрессивное, властное поведение, ценятся у них физические данные и умственные способности. Но, если подростки с низким социальным статусом склонны делать акцент на власти и демонстративности, то подростки с высоким социальным статусом больше на активности, агрессии и враждебности. Если самооценка снижается, то это приводит к саморазрушающим тенденциям, к трудностям в общении, связанным с тревожностью и с низкой самооценкой у подростков с низким социальным статусом, и связанным недостаточно выраженной физической идентичностью, и с неудовлетворенностью собой у подростков с высоким социальным статусом. В обеих группах выступает показатель внешней привлекательности. У «низкостатусных» подростков она связана с умственными способностями и счастьем, а у «высокостатусных» подростков с уверенностью в себе и с общительностью. На основе корреляций, связанных с показателями «количество позитивных выборов», можно предположить, что подростки с низким социальным статусом в целом имеют более низкую самооценку вследствие именно оценки своего статуса в социальной общности и испытывают трудности в общении. А подростки с высоким социальным статусом и частично вследствие своего «высокого» статуса, наоборот, более удовлетворены собой и не испытывают трудностей в общении.

В наше время под влиянием мирового развития, изменяет тип связей и, соответственно, модели поведения, которые подростки социально переиначивают при установлении социальной связи. Они все меньше замыкаются в рамках групповой и традиционной модели, а строят свое отношение из стойких групповых культур, что дает им возможность самостоятельного выбора обще человеческих ценностей [3]. Следующим условием самосознания подростка, является его творческая способность конструировать деятельность и программы личностного развития. Их содержание и объект саморазвития - личностная целостность и внутренняя сконцентрированность социально-ролевых 
форм опыта. Ее можно сопоставить с освоенной индивидуальной культурной реальностью подростка. Данный конструкт взаимосвязывает личностное пространство подростка, создавая индивидуальный стиль поведения, совершенствуя моральные убеждения, позитивное взаимодействие, онтологическое доверие к окружающему социуму и способности реконструировать социокультурные характеристики эмоционально пережитого индивидуального опыта.

Описанный процесс социального самосознания резюмирует проблему становления социального развития, который должен быть аксиологично объективированным и ориентированным на ценности, которые будут определять характер жизнедеятельности подростка в современном обществе.

Заключение.

В настоящей работе был проведен сравнительный анализ самосознания подростков с разной культурной подготовкой и социальным статусом. В обществе, которое утратило прежнюю идеологию, подросток оказался в непростой ситуации. Соответственно, изменилась интеллектуальная и духовнонравственная позиция на крайности современного развития. Подростки находятся в среде, отмеченной нестабильностью, где родители перестали играть стабилизирующую роль в семье. Личность «индустриальной ментальности» оказалась неприспособленной к переменам в обществе, нацеленном на познавательную, мыслительную деятельность его граждан. Поэтому необходимо:

- Учитывать субъективный опыт каждого поступающего подростка в высшие военные учебные заведения министерства обороны, его потенциал по саморазвитию.

- Подготовка офицера не должна входить в противоречия с внутренней природой курсанта, а должна охватить все возможности личности, а не относительно узкий их набор при службе в вооруженных силах.

- Учеба курсанта должна стать центром эмоциональной защищенности и источником позитивных творческих преобразований.

Наряду с высокими воинскими требованиями необходимо учитывать индивидуальный характер и стиль усвоения воинских знаний, вариативность, широкий спектр индивидуальных вариантов организации прохождения офицерской подготовки.

Обучение в высших военных учреждениях необходимо сделать процессом, в котором присутствует своего рода «набор» положительных образцов как центров самореализации обучающегося военнослужащего. Для этого стиль развития воинского чутья, ответственности должен соответствовать созданным социальным условиям, который предусматривают не только активное включение курсанта в различные формы деятельности, а и в приобретении воинских навыков, умение гибко менять свое поведение в зависимости от обстоятельств и тем самым преодолевать сложные ситуации.

В воинской подготовке для подростков с недостаточно высокой социальной компетентностью и невысоким социальным статусом необходимо создать «зону социальной экологичности» - стимул развития без цензуры недостатков в пространстве воинской среды. 


\section{Список литературы:}

1. Агафонов А.Ю. Основы смысловой теории сознания. СПб., 2003. 290 с.

2. Выготский Л.С. Динамика и структура личности подростка. М., 1980. С. 141.

3. Дилигенский Г.Д. В защиту человеческой индивидуальности. 1990. С. 31-45.

4. Иванов О.Е. Самосознание как основа метафизики. Опыт введения в философию. СПб., 2002. С. 14.

5. Крайг Г. Психология развития. СПб., 2000. 992 с.

6. Красновский В.Н. Особенности социальной ситуации развития современного подростка //

Педагогика толерантности. 1999. № 2. С. 64-72.

7. Кон И.С. Психология ранней юности. М., 1989. 255с.

8. Коростылева Л.А. Психология самореализации личности: основные сферы жизнедеятельности.

СПб., 2001.

9. Кулаков С.А. Психотерапия и психопрофилактика аддиктивного поведения у подростков. М., 1996.

$48 \mathrm{c}$.

10. Матейчек 3. Родители и дети. М., 1992. 300 c.

11. Ницше Ф. Соч.. М., 1990. С. 24.

12. Фролов Ю.И. Психология подростка. М., 1997. С. 6.

13. Райс Ф. Психология подросткового и юношеского возраста. СПб, 2000. 656 c.

14. Федорова Г.Г. Трудный подросток: становление личности. СПб, 1992. 32 c.

\section{References:}

1. Agafonov A.Y. foundations of semantic theory of consciousness. SPb., 2003.

2. Vygotsky L.S. Dynamics and structure of an adolescent's personality readings in developmental and educational psychology. M., 1980. P. 141.

3. Diligence D. In defense of human. 1990. Pp. 31-45.

4. Ivanov O.E. self-Awareness as the Foundation of metaphysics. The introduction of philosophy. SPb., 2002.

P. 14.

5. Craig, developmental Psychology. SPb., 2000.

6. Krasnovsky V.N. The characteristics of the social situation of development of a modern teenager // Pedagogy of tolerance. 1999. № 2. P. 64.

7. Kon I.S. Psychology of early adolescence. M., 1989.

8. Korostyleva L.A. Psychology of the self: the main spheres of life. SPb., 2001.

9. Kulakov, S.A. Psychotherapy and psychological prevention of addictive behaviors in adolescents. M., 1996. $48 p$.

10. Matejcek z Parents and children. M., 1992. 300 p.

11. Nietzsche F. Op. M., 1990. P. 24.

12. Frolov Y.I. Psychology of the adolescent. M., 1997. P. 6.

13. Rice F. Psychology of adolescence and youth. SPb., 2000.

14. Fedorova G.G. Difficult teenager: the formation of personality. St. Petersburg, 1992. 32 p.

(C) 2014, Красновский В.Н., Баловнева Я.В., Басотина О.М., Кутузов Е.Л., Моруженко Н.А. Изучение самосознания подростков мужского пола, поступающих в высшие военные учебные заведения Министерства обороны Российской Федерации
(C) 2014, Krasnovsky V.N., Balovneva Y.V., Basotina O.M., Kutuzov E.L., Moruzenko N.A. The study of self male adolescents coming in higher military educational institutions of the Ministry of defense of the Russian Federation 
DOI: $10.17117 /$ no.2014.01.131

Поступило в редакцию: 19.11.2014

vka@mil.ru

\title{
Красновский В.Н., Кутузов Е.Л., Теренин А.Е., Дурнов И.В., Моруженко Н.А. \\ Человек в современном информационном пространстве
}

\author{
Krasnovsky V.N., Kutuzov E.L., Terenin A.Ye., \\ Durnov I.V., Moruzenko N.A. \\ People in the modern information space
}

В статье рассматривается вопрос трактовки информационного пространства, который бы достаточно четко помог связать психическую осознанность детерминаций человеческих действий в социальных сетях и общественного медиа. Авторы придерживаются мнения, что информация существует в нашей жизни обособлено, являясь источником суверенности, которая конкурирует с развитием человека в его способности к символическому выражению реальности

Ключевые слова: конформизм, потребление, сетевое общество, дигитализация, пуелиризм

\section{Красновский Валерий Николаевич}

Кандидат психологических наук, доцент

Военно-космическая академия им. А.Ф. Можайского г. Санкт-Петербург, Ждановская ул., 13

\section{Кутузов Евгений Леонидович}

Преподаватель

Военно-космическая академия им. А.Ф. Можайского 2. Санкт-Петербург, Ждановская ул., 1

\section{Теренин Андрей Евгеньевич}

Кандидат психологических наук, преподаватель Военно-космическая академия им. А.Ф. Можайского 2. Санкт-Петербург, Ждановская ул., 1

\section{Дурнов Игорь Викторович}

Старший преподаватель

Военно-космическая академия им. А.Ф. Можайского 2. Санкт-Петербург, Ждановская ул., 1
The article considers the question of interpretation of information space, which would clearly help to link mental awareness determinations of human action in social networks and social media. The authors are of the opinion that information exists in our lives in isolation as the source of sovereignty, which competes with human development in his ability to symbolic expression to reality

Key words: conformity, consumption, network society, digitisation, polarism

\section{Krasnovsky Valery Nikolaevich}

Candidate of Psychological Sciences, associate Professor

Military space Academy Alexander Mozhaisky St. Petersburg, Zhdanovskaya st., 13

\section{Kutuzov Evgeny Leonidovich}

Teacher

Military space Academy Alexander Mozhaisky

St. Petersburg, Zhdanovskaya st., 13

Terenin Andrey Yevgenievich

Candidate of Psychological Sciences, the teacher Military space Academy Alexander Mozhaisky St. Petersburg, Zhdanovskaya st., 13

\section{Durnov Igor Viktorovich}

Senior lecturer

Military space Academy Alexander Mozhaisky

St. Petersburg, Zhdanovskaya st., 13 


\section{Моруженко Николай Анатольевич}

Кандидат психологических наук, профессор

Военно-космическая академия им. А.Ф. Можайского

г. Санкт-Петербург, Ждановская ул., 1
Moruzenko Nikolay Anatolievich

Candidate of Psychological Sciences, associate

Professor

Military space Academy Alexander Mozhaisky

St. Petersburg, Zhdanovskaya st., 13

Постановка вопроса. Контекст нашей эпохи - сетевой эффект: информационное пространство или общинная жизнь массовой коммуникации и компьютерное время Интернет. Человек, соприкасаясь с киберпространством, располагает возможностью понять, как оно действует вещественно в социальных актах его жизни, в каких формах производит преобразования в его мыслях и узнавать, что отражают понятия, образы, содержащиеся в конструкции его задач - от переработки информации к коммуникации. Подобный доступ проистекает благодаря тому, что современное информационное пространство, как реальная индустрия сетевых сообществ, представляет собой персональные группы пользователей, не имеющих лидеров (Ханс-Магнус Энцесбергер), а значит остается самоуправляемым обществом свободно предпочитаемых связей. Такая Интернет-культура сетевой демократии держится на приватизации общения и в социальном аспекте выглядит крайне индивидуалистически.

Собственно, в качестве ресурса связи здесь используются формы общения, или правила игры, позволяющие осуществлять символические действия вламывающегося на весь процесс коммуникации события. Соотношение между индивидуалистическим содержанием информации, и ее практической потвержденностью требует определенности, или различенности, поскольку подобное интернет-общение наполнено некой нарастающей смесью из убеждений и желаний. Это мир упрощенных причинно-следственных связей. Следовательно, в действии, конкурирующие системы СМИ и Интернет, вынуждены предоставлять в сети не чье-нибудь мнение, а утверждают темы находящими своего искателя для личного эмоционального комментария в них. Здесь главным основанием переработки информации для общения или, как принято обозначать, дигитализации остается полиморфизм ценностно-смысловых установок ее потребителей. Пользователь, находясь в пространстве социально-сетевой коммуникации, получает свободный доступ организовать свое публичноприватное время. Этот потенциал используемого времени на рынке бесчисленных ниш и личных вкусов дает осетевленному человеку возможность конструировать и выражать свою субъективность в выборе развлекательного события характерных для детерминации любых жизненных процессов, исходящих из опыта, личных интересов и без них. Данный выбор можно понимать, как структурную игру ценности, веры в то, что найдено место действия личной свободе и независимости.

Практически тематическая информация культивирует доступ к реалиям современной социальной действительности, где человек выступает символическим знаком заданной социальной игры между стрессом и скукой. Целостное «Я» человека в этой игре, индивидуализировано инертно. Эта определенность, наполненная конкретным действием, однако имеет социальное содержание и 
является самым эффективным средством свободно выбираемых связей пользователя информации.

Содержательная символика информации подразумевает знаковое обозначение, сопутствующее понятию «пользовательская психологическая поверхность». Ее психологический уровень сохраняет один и тот же базовый сетевой эффект происходящего процесса - применять различные модели входных режимов “насыщения” информацией, находить новые тематические поверхности ее варианта, держась на различиях психологической подачи информационной части. Учитывая, привлекательный подход сетевой индустрии к решению тонких и сложных проблем доступа к масс-медиа информационное пространство реализует свой потенциал, через метод множественного доступа с прослушиванием. Эти методы являются ведущими, что позволяет информационным сетям через свою систему в информационном секторе решать сложные психологические задачи вовлечения человека в социальнопсихологическое пространство. Этот выстроенный алгоритм разноплановый не следует воспринимать как полное отражение проблемы. Информационные модели сетевой информации являются целостным комплексом, «смысловым» полем - некой реальностью, имеющую большие социальные последствия и, влияющие на культурные и глобальные изменения. В связи с этим возникает острая необходимость прогнозировать их развитее.

Анализ ситуации. Мы живем в эпоху информационных инноваций, повышенной миграции. Нестабильность экономической и политической жизни заставляет многих людей искать более удобные и экологически защищенные места. Эта необходимость взаимодействия в разрешении жизненных проблем структурирует сотрудничество между людьми. Расширяется составляющая системы общественного сознания, формирование которой определяется многочисленными и многоплановыми отношениями, соответствующих социокодов и ментальных «карт» («географии поведения» за Л. Гумилевым), через которую человек осваивает контекстуальное пространство, а, значит, учится соотносить личный опыт с разными типами реальности. Такие взаимосвязи в социальном пространстве должны быть ориентированы на идентификационную программу индивида, при которой проработанная информация определяет характер и уровень индивидуальных умений в выборе адекватного поступка. М. Маффесоли пришел к выводу о том, что различные группы населения формируются вокруг идеального образа современности [1] и такой образ современности создает, отчасти контролирует, информационное пространство.

Сегодня современная реальность выражает себя новой формой отношений, все более возрастающих активных видов сотрудничества, направленных против пространств, препятствующих потоку новых идей и видов деятельности. Это создает условия для изменения картографии добывания материальных благ и активизирует значимые регионы, где они с наибольшей экономией могут получить поддержку. Влияние регионов среды друг на друга выражается легкостью перемещения - локомоцией (Курт Левин) человека с одного регионального пространства в другой. Совершая осваивание территории, человек прокладывает путь через среду. 
Словом, современный социум становится более открытой областью для применения новых возможностей и нестандартных решений личности. Но, расширяя границы для активности каждого члена общества, современность одновременно оставила человеку незавидную роль, сделав его дубликатом необходимого ей социального знака. Таким образом, человек оказался в ситуации биполярной оппозиции между индивидуальной личностью и социумом. Ее цена психологическая - дефицит внимания.

Понятие «информационное пространство» и сегодня сохраняет статус неопределенного представления. Невыясненная реальная мотивированность действий информации, для человека затрудняет оценку ее программ и препятствует правильно распознавать содержательные формы ее идеологии. Поэтому добиваясь отклика на идеологические информационные постулаты, информационная сеть не только идентифицирует человека как субъекта, но и подчиняют его субъективизм в форме поддержки существующих структур власти. Институт информации осознается, как призрак непредставимости, лишающий человека в социальных сетях его индивидуальности, право на самостоятельную мысль, инициативности, выходить за правила игры. Обесценивание человека информацией - это его не замечание при завоевании личностной интеллектуальной территории. Психическая жизнь информационного пространства не просто соглашения, а и актуальная активность на смысл повседневности. Условия ее адекватности на территории социального пространства - вызывать и создавать определенное поведение личности.

Сам характер взаимодействий в сетевых контактах обусловлен ностальгией за идеальным содержанием прозрачности сообщения и росте его применения. В информационном пространстве эти ментальные «переживания» сетевого «массажа» в психических процессах и поведении человека вызывают реактивные образования, устанавливая простые отношения между выбором важного для них «поглощенного» события и его переозначением. Подобные формы обмена проявляются в желании понять порядок и «распробовать» полноту ощущений субъективного опыта от эффекта виртуального кода. Пространство «пробы» приводит в действие не удовлетворенное желание соответствовать мыслящей аудитории и построить собственное развитие. Под влиянием информационного пространства развитие придает настоящему «опробованию» новую психическую действительность.

Повседневная жизнь человека в современном социуме, характеризуется потерей образа привычной среды, что зарождает у активной части населения самостоятельно выстраивать собственную систему связей. Вызвано это необходимостью приспособить свою субкультуру к месту «действия», поскольку человек в новой знаковой модели общества вынужден учиться обладать множеством частных идентификаций, выходящих за пределы общественных связей. Такая форма построения среды в качестве значимых кодов базовой структуры господствующих в обществе ценностей по отношению к человеку трансформирует ролевую социальную структуру, видоизменяя отношение территориальной «близости». Вот почему привычные пространственные места чело- 
века лишены своего субкультурного значения. Они все активнее «сопротивляются» многомерной среде.

Характер этих изменений привел и к появлению пуелиризма, позиции общества, в котором поведение не отвечает уровню разумности и зрелости, какое оно достигло в силу своей способности оценивать отношения. д.| В данных общественных формах характер поведения можно обозначить как социально аномальный: свое личное поведение взрослые приспосабливают к управляемой тактике. Избегание активности, как позиций устойчивости представляет особые идентичности через признанные субкультурные ценности, «картография» которых простирается от потребительского устремления до утопических проектов личного «захвата» мира. Здесь референтный стереотип теряет отчетливость границ и существенно модифицируется. Почувствовать себя «другим» в существующей ситуации вызвано кризисом идентичности в пространстве повседневности.

Обыденное информационное пространство пластично, оно формирует нужный образ самостоятельности личности в ролевом своеобразии, расширяя сферы жизненного мира человека. Для мыслящих индивидов здесь появляется возможность раскрыть активность своей позиции, которая обладает высокой потенциальной оживленностью. Ради собственного выживания такой социально мотивированный человек приспосабливает индивидуальное жизненное пространство к задачам общества. В связи с этим возникает необходимость определить поведенческие модели, которые дают индивиду возможность расширить границы личного «овладения» пространством. Такие действия «вбирают» дефрагментрированность культурного пространства спонтанных объектов внимания, того или иного человека.

Информационное пространство определяется нами, как система, в которой процессы социальной реальности охватывают общесоциальный и индивидуальный уровни ассиметричного самосознания личности и «закрепляют» за ней имеющую влияние модальность, видоизменяющую набор ценностей, которые она направляет на важные для нее объекты влияния. В результате этого, реальными стали стереотипы сознания, потребностей, социального поведения, налаживание быта, религиозная апотропея (отвод или оберег от социальных невзгод) и т.д., которые нивелируют личностные и индивидуальные характеристики, выражающие себя в конформизме, в мыслях и поведении, как нормах общественной жизни. Психический фактор личностей потребительского, конформистского характера самокультивирует данное сознание, искажая трансцендированную наличную реальность, отчужденную от реального мира.

Действительно, потребление стало частью жизненного стереотипа современного общества. Появление таких институтов потребления как супермаркеты, где в изобилии пестрят предметы культур цивилизаций и их знаковые эталоны, никого не оставляет равнодушным. И если учесть, что часть населения живет в мире искаженных представлений, то «зазор» между необходимостью и потребностью все более расширяется. Эта культура невроза стала проявлять себя как социальный знак расширения, затрагивающий сферу культуры человека, но подменяемой технологическим воздействием. Расширяя по- 
требительский спрос, маскируется возможность контролировать огромный пласт современного общества. Личность впервые столкнулась со смещением этнической самостоятельности в сторону новой социальной реальности. Прежде всего, ей стал доступен дифференцированный аспект знаковообразной системы потребления жизни более широко, чем ранее, затронувший и вовлекший ее в другие культурные традиции. Это создало условия для социальных трансформаций личностной психологической реальности или перемоделирование личной ментальной карты в сторону глобального «расширения личности» (выражение Мак-Люэна).

Мы все время наблюдаем за тем, как в нынешнем пространстве разрушаются прежние стереотипы порядка, запускается процесс «глобальной» ментальности, который перерос в формы предметной и культурной доступности. Здесь со всей очевидностью проступает значимость для современного человека позиция удвоения. «Я» может быть востребован Другим, что создает актуальный прецедент для развития диалога в пространственной сфере социального знака и, при этом, сохранять индивидуальный почерк. В такой социальной среде, чтобы овладеть социальной мудростью и индивидуальной свободой, необходим опыт исходных ценностей обмена вовлеченности человека в рациогуманистическую (Балл Г.А., 2006) действительность повседневной жизни.

Культура потребления «заставляет» освоить социальный знак вглубь, благодаря чему человек может получить опыт метакогнитивных орудий и освоить их внутри времени обычной жизни. Востребовать социальный знак в своем понимательном виде значит вносить контент (личную знаковую информацию) в сферы обмена.

Социальный знак потребления затрагивает важную сторону социокультурного порядка, где мы существуем, и что организует для нас связанный контекст [3]. Этот порядок динамичен и не может допускать мир «без содержания и смысла». Интерсубъективный мир человека в повседневной жизни функционирует как схема референции - ее объективный взгляд на реальность. Это формирует социальный образ позиции внешнего и внутреннего в психических границах самого человека к потенциальному содержанию знака потребления. Данный образ варьируется при смене социального контекста, но неразрывен и един, а это в свою очередь дает возможность находить и соизмерять нескончаемое разнообразие реальности, формируемое в сфере личного опыта акта интерсубъективной способности к перепроектированию социальной эстетики «Я». Здесь позиция «Я», обладающая высокой потенциальной активностью, приспосабливает реальный мир к своим задачам, унифицируя поля обмена в социальных товариществах.

Такая социальная модель отношений выстраивается как поток расширенного пространства самостоятельности человека за счет непрерывной смены ролей, разыгрываемых в различных сферах соотношения "я - общество". Местность потребления «глобальной» ментальности «улучшает» информированностью этническую среду. Она, разобщая ее локальные позиции рефлексирует межпланетарный стереотип, допуская интонацию его однополярной «избранности». 
Культура потребления выдвигает требования, своего рода культурные эталоны, к продуктам творческой деятельности человека, что способствует созданию условий для появления интеллектуальных инноваций. Это повышает комфортный уровень формирования новых форм и правил поведения, изменяя образ жизни человека в социальных интерперсональных взаимодействиях.

Постигнуть сложные стандарты жизнедеятельности, в условиях потребительской культуры «разрывающую» реальность личности в информационном пространстве не просто. Ей надо стать автономной и гибкой в выборе социальных ценностей и их символов. Соответственно, социальный успех будет зависеть от ее умения адекватно использовать ведущие мировые ценности и символические коды к определенному типу социума, например, такие как: язык, социальные ценности, семейные правила, социальную философию этноса, одежду и другие.

Пользователя сетевой информации притягивают своим внешним подобием места контакта, где группируются сообщества, которые близки или идентичны его внутреннему миру. Такое окружающее его информационное пространство воспринимается им как идеальный мир: здесь социальные отношения носят характер разрешающего действия (сообщество «подобно» мне самому!). Во всех без исключения информационных сообществах групповые взаимоотношения являются нормативно регулируемыми. В этих пространствах, допускающих контакт, пользователь позволяет себе делать все, что определяет его ролевой интерес в сообществе. Информационный контакт своего рода эквивалент, регулирующий различные формы взаимоотношений, место собственных детерминант индивида и его «маркировка». Сетевой статус исходная социальность, модель ролевой идентификации. Благодаря статусу, пользователи сети могут рассчитывать на социальную «безопасность», поддержку и одобрение своих амбиций без боязни быть подвергнутыми осуждению или критике. Для немногих такие объединения стали эталоном собственной «успешной» жизни. Здесь они «завоевывают» неосвоенные места, чтобы соответствовать межличностной норме, превосходящей их социальный предел. Данная категория, боясь оказаться на самом нижнем этаже информационной группы, очерчивает границу, обеспечивающую им постоянство быть «образцом» всеобщего сравнения и соответствовать стандарту «подготовленности». Пользователи сети хотят получать больше, поскольку у них есть потребность в новых ощущениях, а они сопоставимы только с достаточно напряженными эмоциональными затратами. Погоня за статусом становится, своего рода разбросом межличностных оценок, определяющих «спорные места» конформности, а это тождественно оптимизации «покоя» в информационных отношениях.

Формирование новых форм и правил поведения, образование более цивилизованных отношений между людьми изменяют образ жизни человека, выводя личность на иной качественный уровень трудовой мобильности. Сегодня процесс социального развития не возможен без учета мер обеспечения социального равенства и сбалансированного экономического развития. 
В наше время изменяются типы связей между людьми и, соответственно, модели поведения, которые все больше становятся индивидуализированными. В процессе усиления этой тенденций личностное сознание человека не может быть ограничено только рамками групповой и традиционной модели. Это толкает большинство социальных индивидов, из устоявшихся эталонных образцов групповых культур, реконструировать традиционные цели насущным потребностям общества. Такая ориентировка помогает найти невостребованные резервы и их освоить. Человеку, использовать в сложных системах общества, накопленные социальные резервы, приходится индивидуализировать выбор стратегий, чтобы идентифицировать соответствующую этническому большинству форму поведения. Таким путем она производит социальное сравнение своей идентичности и взаимного согласования жизнедеятельности на уровнях межгрупповых и внутригрупповых процессов в социальных структурах общества. Глобальные системы определяют сферу активности, связанной с ориентацией человека на осмысление эталонов социально - ролевой идентификации окружающего его общества. С психологической точки зрения это можно рассматривать, как выбор «образца» социализации с положительным эффектом.

Мы еще недостаточно оценили психологическую систему символов и значений, влияющих на функционирование сетевых технологий к зонам особого внимания, таких как: определение значений ключевых смыслов социальным символам, методам психологического влияния информации в сетевой культуре.

В сфере сетевого социального знака главной особенностью является то, что создается глобальное информационное пространство подобно нашей нервной системе, где места взаимодействия могут обмениваться и переводиться друг в друга. Собственно это подводит нас к осмыслению того, что Л.М. Веккер [1] называет законами психического изображения физической реальности, обосновав, что психические процессы по общим свойствам и закономерностям, подобны информационным. Их специфичность выражается в том, что на перцептивном уровне психическая информация проявляет себя в виде программы действий целостного семейства вариантов, позволяющие человеку одновременно и неразделимо воспринимать, определять и реагировать на окружающее его пространство.

Равноположную позицию занимает и Н. Винер [2]. Подвергая человека анализу в информационном пространстве, он считает его фундаментальной информационной сущностью, паттерном (образцом) физической информации, физическим объектом или процессом, который партиципирует (соучаствует) креативному процессу «вхождение в бытие» с другими материальными объектами. Человек и есть творение информации. Отсюда вся физическая структура человека детерминирует природу и сложность информационного процесса. Информационная природа человека делает возможной для нее интеракцию с другими информационными сущностями в окружающей среде, не исключая связи и сетевого обмена. Н. Винер рассматривает процесс получения и использования информации как нашу адаптацию к случайностям внешнего окруже- 
ния. От этих случайностей зависит эффективность нашей жизни внутри данного окружения. Востребовать социальный знак в «своем» понимательном виде - прорыв для позитивного модифицирования информации, осмысленной в терминах информационного пространства.

Акцент отношения к модифицированной информации здесь будет смещаться в сторону смысловой интонации своевременно узнаваемой знаковой системы для личного изучения реального мира. Проработка этого сложного опыта в овладении способностью обнаруживать, идентифицируясь с тем или иным знаком, помогает пользователю сети моделировать любого рода задачу. Получить объективные характеристики о деятельной сфере знака - это все равно, что связать его со значением перестроенной концептуальной модели знака. Такая перестройка создает условия повышения его активности в построении межличностного диалога в сети [4].

Специфика распознавания информационного знака дает возможность объективировать алгоритм действия и повысить инициативность его пользователя. Информационная коммуникация может рассматриваться как бинарная операциональность: выступать физическим явлением, обнаруживая данные не интерпретированные в количественных обобщениях и синтаксически, проявляющаяся в значении, релевантности, интерпретации достоверно сформулированных различий языковых символов. Образование новых связей в сетевой индустрии направлено на результат формирующего субъективный опыт пользователя. В основе этого итога лежит процесс вовлеченности личности в ее систему. Это вынуждает информационные технологии модифицировать свою структуру, непрерывно создавая более сгруппированные в пользовании единицы материализованных операций, чтобы они были доступны каждому пользователю и повышали его инициативность. По мере расширения для нужд информационного пространства социального и физического знака вырабатываются упорядоченности различных состояний насыщения информации, превращая ее в общедоступный контактный знак сетевого общения. В итоге, если спроецировать весь этот процесс на социум, он будет соответствовать зоне грамматического сетевого пространства, формирующую среду в сфере его влияния. Вот почему влияние информации продолжает расти.

Исходные исследования мы получили и в изучении поведения личности в различных социальных отношениях. Они схожие с данными сетевых систем. Нами исследовано сто двадцать реципиентов от 17 до 22 лет в межличностной сфере. Полученные, путем прямого наблюдения данные за вариативностью их поведения, указывает нам на объективное существование социальных механизмов, управляющих функционированием, перестройкой и приспосабливанием к социальным связям подобно сетевым модифицированного алгоритма. Выделение параметров этих механизмов можно было наблюдать в самоорганизованной непредумышленной динамике, которая функционирует в социальной норме достаточно слажено и слитно. Используя приемы перегруппировки соотношения связей сходно с их распределением значений в социуме, совпадает с исходом собственных традиционных представлений личности, что в каналах информационных сетях могут соответствовать трем события: успех, 
неуспех, конфликт. Это наводит на мысль, что результаты сетевых и социальных систем развиваются равно, что затрагивает одинаково код информационной технологии и сенсорный, социальный уровни отношений межличностного пространства человека.

В нашем исследовании выявлено также социальную инфантильность и негативизм к реалиям современной социальной действительности. Это сигнал того, что назрела необходимость сформировать новый, соответствующий современности, методологический подход для решения вопроса о дальнейшей социально-психологической коррекции населения, подталкивая ее к процессу самовыражения для овладения проявляющей себя реальности, к которой в данном промежутке времени она еще индивидуально инертна. Если мы хотим видеть человека здоровой и социально активной личностью, информационное пространство должно нести ему развитие и поддержку.

Заключительный аспект. Информационное пространство объективируется через символические социальные связи реальности - масс-медия и Интернет. В этих связях значительная роль отводится социальному знаку. Социальный знак (событие или явление) - языковый референт (сообщитель) признаков коммуникации. Он формирует пользовательскую иерархию. Его психологическое проявление создает реальность окружающей яви, образовывая среду «проинформированных» и, таким путем, дифференцируя социум. Создав пустое пространство и, исключив страх перед мнением, социальный знак взорвал реальность человека.

Идеология информационного пространства - ставка не на профессионала, а на любителя. В таких условиях трудно упорядочить реальность: ум и безумие взаимно подпитывают друг друга. Данное пространство порождает самоорганизацию знания дилетантов, которые, например, дает Википедия. Таким образом, стихийная идеология совпадает с областью знаков, захватывающих пользовательские массы. Это подпитывает степень интенсивности социальных отношений. Смысл подобной коммуникации в самой коммуникации, дарящей контакты.

Из выше сказанного, необходимо сделать следующие предположения:

1. Информационное пространство формирует сетевое общество с неформальным характером.

2. Создается демократическая сетевая общность, как самоуправляемое общество свободно предпочитаемых связей.

3. Это перестраивает наш социальный порядок, где этническая идентичность лишается своей значимости и позволяет создать сетевые силы соседства, в которых теряются формы социальной иерархии в пользу гетерархаической культуры

\section{Список литературы:}

1. Веккер Л.М. Мир психической реальности / под общ. ред. А.В. Либина. М., 1998.

2. Винер Н. Кибернетика, или Управление и связь в животном и машине. М.: Наука, 1983.

3. Красновский В.Н., Теренин А.Е., Кутузов Е.Л. Информация в социальных сетях и ее влияние на пользователя. Сборник рефератов депонированных рукописей ЦВНИ МО РФ, 2014.

4. Сурова Е.Г. Глобальная эпоха: полифония идентичности. СПб.: Осипов, 2005. 


\section{References:}

1. Wecker L.M. the World of psychic reality / under the General editorship of A.C. Libin. M., 1998.

2. Wiener N. Cybernetics: or Control and communication in the animal and the machine. M.: Nauka, 1983.

3. Krasnovsky C.N., The Terenin, A.E., Kutuzov E.L. Information in social networks and its impact on the user. Collection of essays deposited manuscripts, ZUNI defense Ministry, 2014.

4. Severe E. the global era: the polyphony of identity. SPb.: Ed. Osipov, 2005.

(C) 2014, Красновский В.Н., Кутузов Е.Л., Теренин А.Е., Дурнов И.В., Моруженко Н.А.

(C) 2014, Krasnovsky V.N., Kutuzov E.L., Terenin A.Ye., Человек в современном информационном Durnov I.V., Moruzenko N.A. пространстве 
DOI: $10.17117 /$ no.2014.01.142

Поступило в редакцию: 27.11.2014

rector@ssmu.ru

Колосова М.В.

Вклад молодёжи Томской области в формирование стратегического ресурса регионов Сибири

\author{
Kolosova M.V. \\ Contribution of young people of the Tomsk area to forming \\ of strategic resource of regions of Siberia
}

Данная статья посвящена роли молодежи в формировании демографических и социальных процессов в условиях крупного промышленного города Сибири в современных условиях

Ключевые слова: демографический потенциал, социальная политика, регион

\section{Колосова Марина Владимировна}

Доктор медицинских наук, профессор Сибирский государственный медицинский университет

г. Томск, ул. Московский тракт, 2

\begin{abstract}
This article is sanctified to the role of young people in forming of demographic and social processes in the conditions of industrial metropolis of Siberia in modern terms
\end{abstract}

Key words: demographic potential, social policy in the region

\author{
Kolosova Marina Vladimirovna \\ Doctor of Medical Sciences, Professor \\ Siberian state medical university \\ Tomsk, Moscow highway, 2
}

Демографические аспекты в плане состояния современного общества одна из острых и актуальных проблем всех развитых стран. Демографическая обстановка в России остается напряженной, поскольку рождаемость остается невысокой при высоких показателях смертности, остается невысокой также средняя продолжительность жизни у мужчин, что, в совокупности, бесспорно, влияет на характер прогнозов в данном вопросе (рис.1) [3,5-7,11,17,24,27]. Указанные факторы приводят к тому, что $2 / 3$ российской территории заселены как в эпоху неолита, а к востоку от Урала демографическая пустыня накладывается на географическую [2]. По предварительным данным, всего Всероссийской переписью населения 2010 года учтено 142,905 млн. человек, постоянно проживающих в России. По сравнению с переписью 2002 года население России сократилось на 2,2 миллиона человек $(1,6 \%)$, что связано с естественной убылью населения на фоне миграционного прироста. По данным переписи 2010 года, сохранилось характерное для населения России значительное превышение численности женщин над численностью мужчин [5-7]. Соотношение мужчин и женщин несколько ухудшилось в связи с высокой преждевременной смертностью мужчин преимущественно в трудоспособном возрасте: переписью учтено 66205 тысяч мужчин и 76700 тысяч женщин, или 46,3 \% и 53,7 \%, соответственно (в 2002 году - 46,6 \% и 53,4 \%). Средняя ожидаемая продолжи- 
тельность жизни мужчин составила 65,13 лет, женщин 76,3 лет в 2013 году, что превышает аналогичные показатели в предыдущие годы (рис. 2).

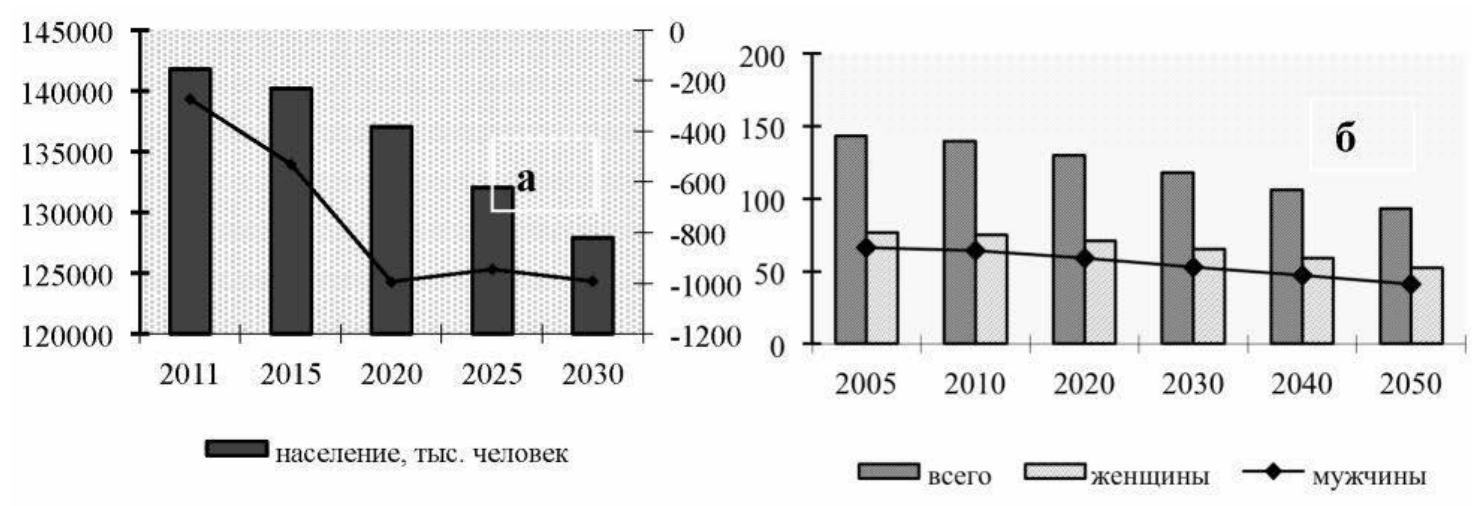

Рис. 1. Изменения численности населения России до 2030 года (тыс., человек) (a), прогноз изменения соотношения по полу (б) $[7,27]$

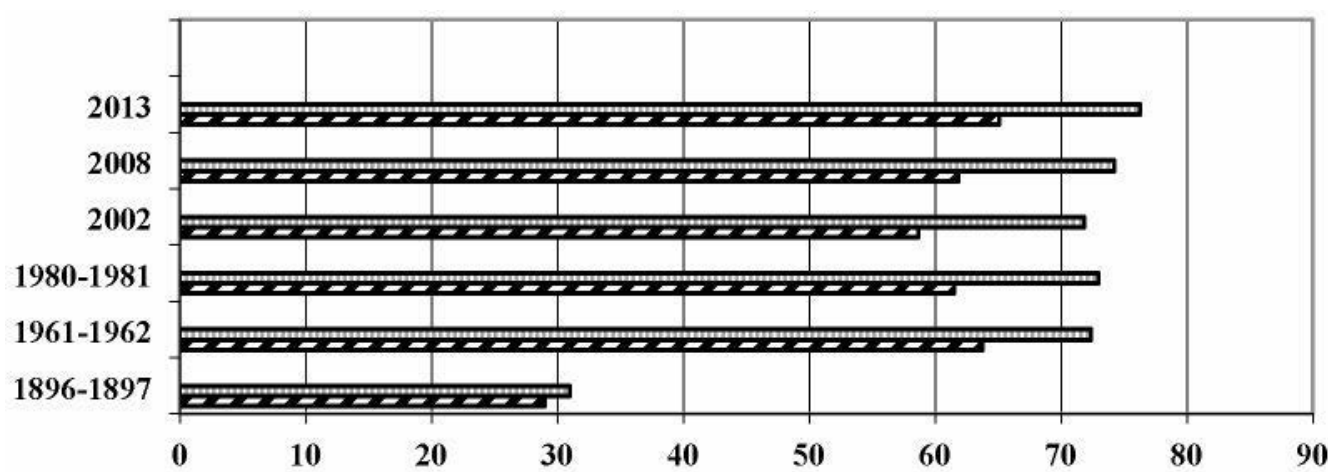

Рис.2. Изменения ожидаемой продолжительности жизни населения России [27]

В Томской области демографическая ситуация в целом повторяет общероссийские закономерности, обретая по некоторым направлениям позитивный тренд, - впервые за последние годы показатель рождаемости превысил показатель смертности, а естественный прирост населения имеет положительный знак (рис.3,4).

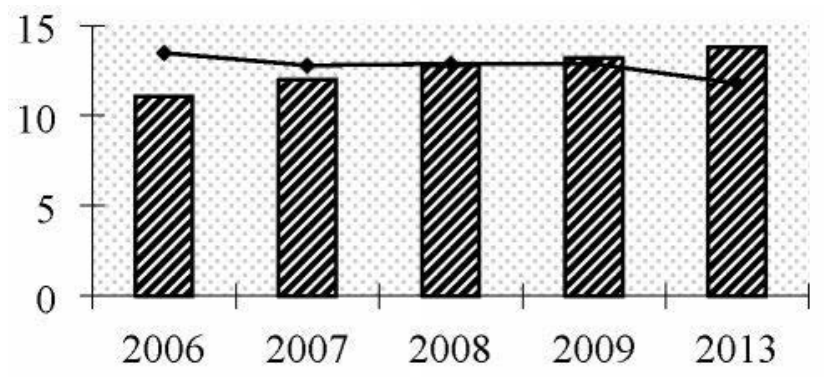

тIग Рождаемость на 1000 населения

$\longrightarrow$ Смертность на 1000 населения

Pис.3. Динамика основных демографических показателей в Томской области 


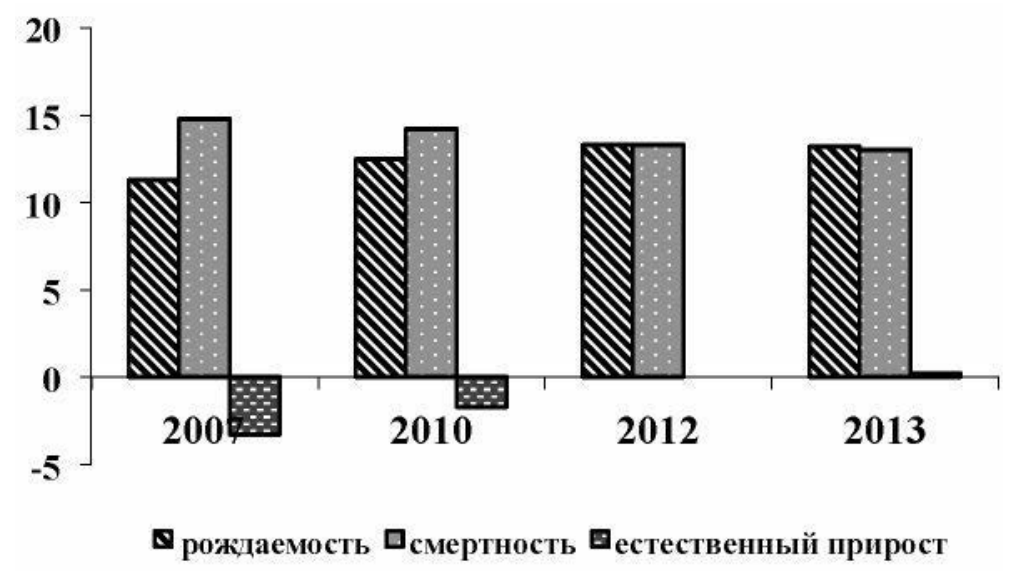

Рис.4. Итоги естественного движения населения в России

Численность населения области по предварительным данным 2010 года практически не изменилась, по-прежнему горожане составляют большую часть населения, а женщин проживает на территории области больше, чем мужчин (рис.5).

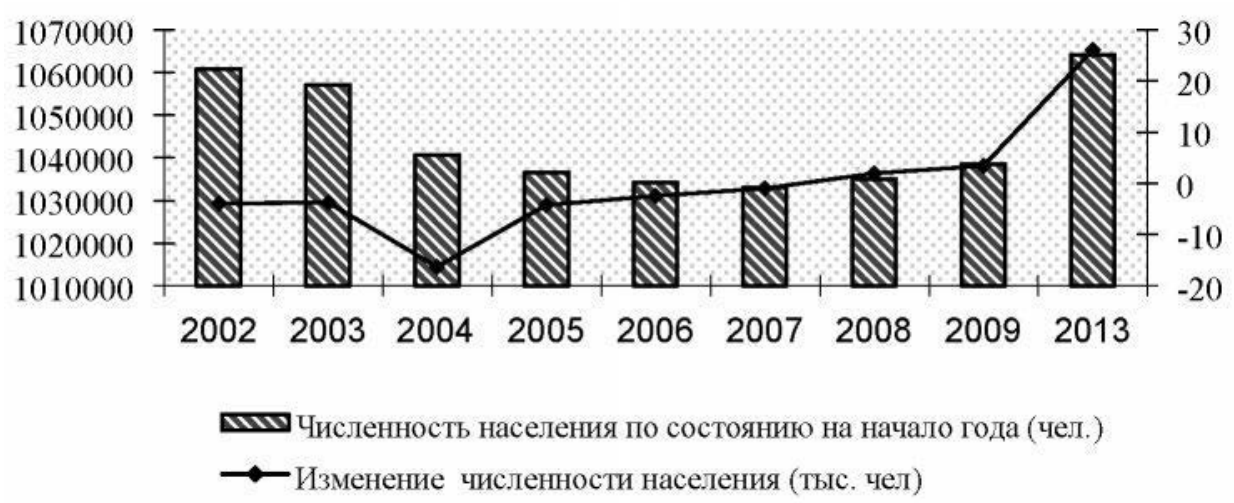

Рис. 5. Численность населения Томской области

Численность населения Томской области по состоянию на 1 января 2013 года составила 1064245 человек (на 01.01.2012 года - 1057748 человек), и за год увеличилась на 6497 человек, или на 0,6\%. Доля лиц женского пола составила $53,0 \%$, или 564,4 тыс. человек в общей численности населения Томской области по состоянию на 1 января 2013 года, численность лиц мужского пола составила 499,9 тыс. человек (47,0\%). На 1000 мужчин населения области приходится 1129 женщин, что, прежде всего, связано с высокой преждевременной смертностью мужского населения. Численность сельских жителей Томской области в 2013 году составила 306,6 тыс. человек и снизилась по сравнению с 2012 годом (308,1 тыс. человек) на 0,5\%; по сравнению с 2009 годом (321,4 тыс. человек) - на 4,6\%. Численность городского населения Томской области по состоянию на 1 января 2013 года составила 757,6 тыс. человек и выросла по отношению к 2012 (749,6 тыс. человек) и 2009 (717,1 тыс. человек) годам на 1,1\% и 5,6\% соответственно (рис.6) [9]. 


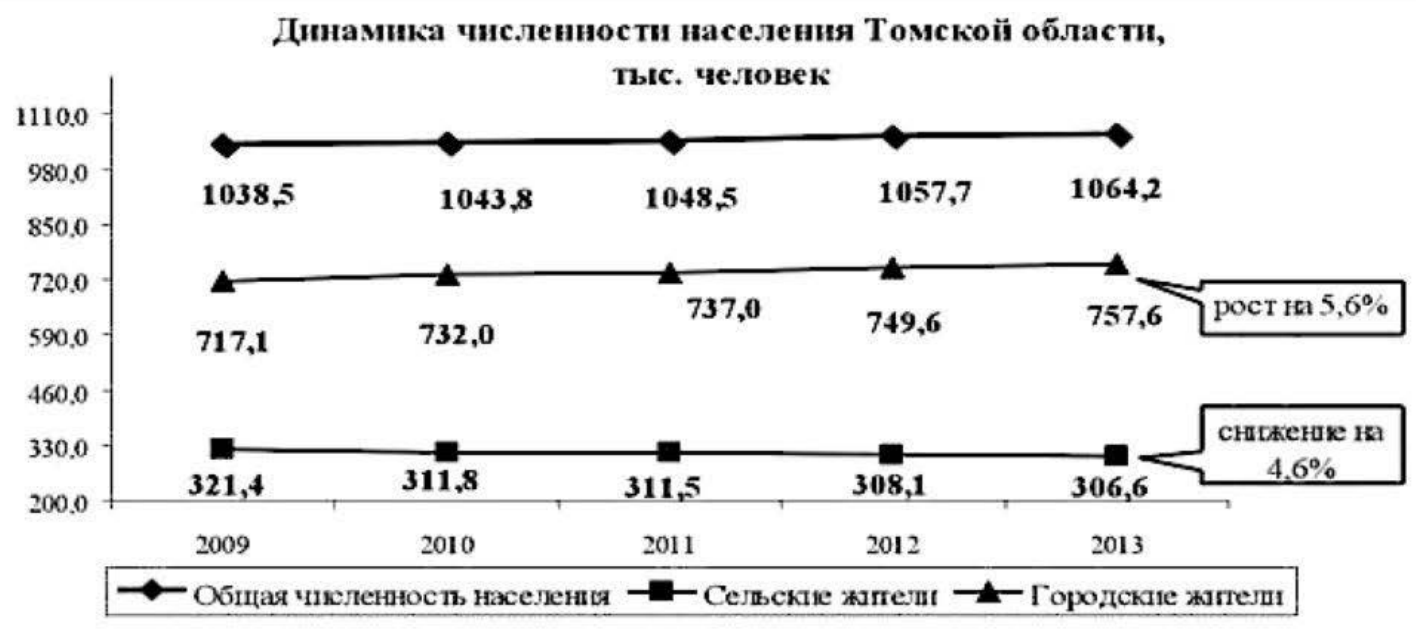

Рис. 6. Динамика численности населения Томской области, тыс. человек

Таким образом, рост общей численности населения области происходит за счет роста численности городских жителей.

За 2013 год число родившихся превысило число умерших на 2189 человек, коэффициент естественного прироста населения составил 2,0 на 1000 населения. По предварительным данным территориального органа Федеральной службы государственной статистики по Томской области в 2013 году родилось 14723 человека, умерло 12534 человек, в том числе в возрасте до 1 года - 103 человека. Коэффициент рождаемости в 2013 году, по сравнению с 2012 годом, увеличился на 1,5\% и составил 13,8 рождений на 1000 населения (2012 год - 13,6), что на $3,8 \%$ выше, чем по Российской Федерации в целом $(13,3)$ и на $7,4 \%$ ниже, чем тот же показатель по Сибирскому Федеральному округу $(14,9)$. Коэффициент смертности снизился на $0,8 \%$ и составил 11,8 случаев смерти на 1000 населения (2012 год - 11,9), что ниже, чем тот же показатель по РФ $(13,1)$ и СФО $(13,3)$ на 9,9\% и 11,3\% соответственно (рис. 7) [9].

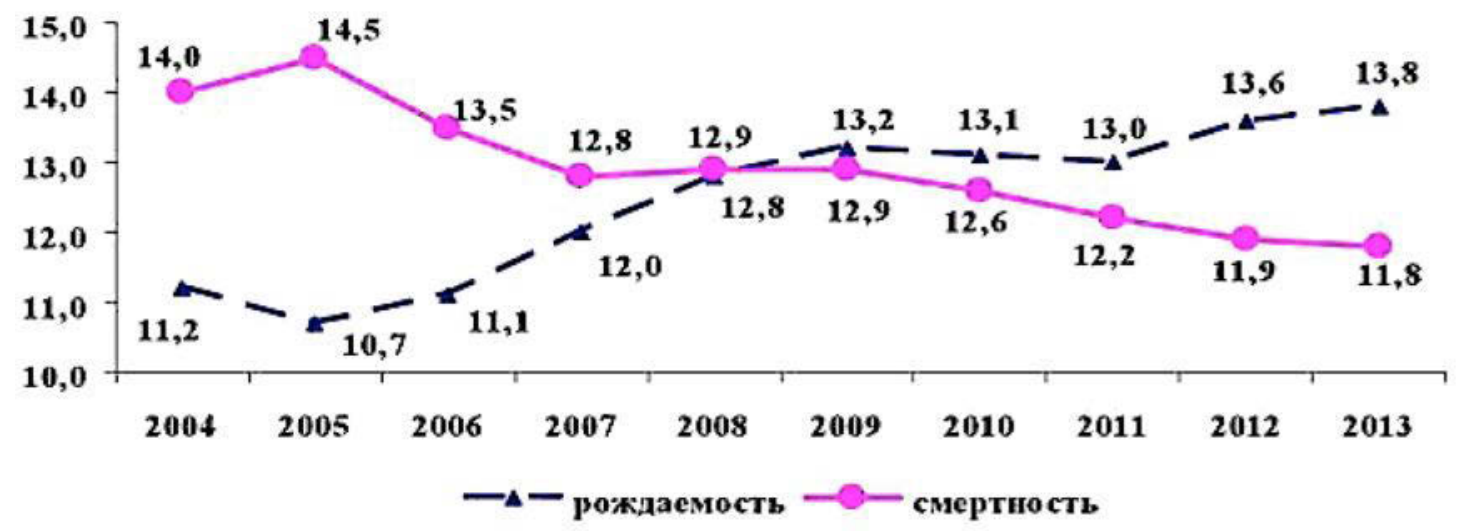

Рис.7. Динамика рождаемости и смертности населения Томской области

Кризисная демографическая ситуация, возникшая в России в 90-х годах $\mathrm{XX}$ века, наряду со сложной политико-экономической ситуацией в стране, также может быть обусловлена снижением репродуктивного потенциала и уровня соматического здоровья молодежи. Репродуктивное здоровье как категория здоровья общества является одним из основных критериев эффективности со- 
циальной и экономической политики государства, фактором национальной безопасности. Репродуктивное здоровье и репродуктивное поведение современной молодежи - важная проблема, однако, в условиях неблагоприятной демографической ситуации особое значение приобретает не просто состояние здоровья подрастающего поколения, а будущий «репродуктивный потенциал» $[16,19,29]$.

Анализ уровня физического развития студентов 1 курсов учебных заведений г. Томска, проведенный на базе МЛПМУ «Межвузовская больница», обслуживающей 9 высших учебных заведений, 16 средних учебных заведений и 9 профессионально-технических училищ общей численностью населения 52 тыс. человек, позволяет утверждать: показатели нормального физического развития снизились, увеличилось количество студентов с дефицитом массы тела и низким ростом, что косвенно свидетельствует об увеличении нарушений в эндокринной системе, расстройствах питания и нарушениях обмена веществ. В структуре общей заболеваемости студентов г. Томска заняли: первое место болезни костно-мышечной системы и соединительной ткани; второе место болезни глаза и придаточного аппарата; третье место - болезни органов пищеварения (рис.8). Анализ гинекологической заболеваемости свидетельствует о фиксировании практически всех зарегистрированных нозологических форм у молодых томичек: хронический сальпингитом и оофоритом, дисменореи, миомы матки и эрозии шейки матки, различных форм бесплодия.
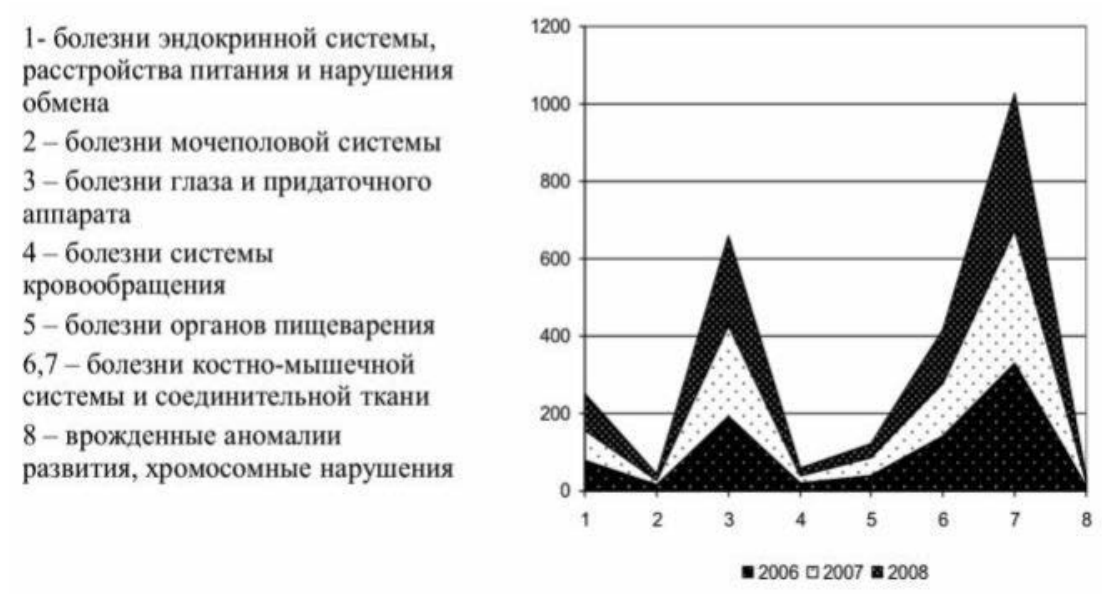

Рис. 8. Анализ заболеваемости студентов г. Томска (на 1000 населения)

Согласно отчету ВОЗ существуют 11 стран с высоким бременем туберкулёза, которые не смогут достичь одной или нескольких целей по сокращению заболеваемости, распространенности и смертности от туберкулёза, в том числе три страны, для которых уточненные данные будут получены в 2013 или 2014 году. В список этих стран входят: Демократическая Республика Конго, Зимбабве, Кения, Мозамбик, Нигерия и Южная Африка в Африканском регионе; Афганистан и Пакистан в Восточно-Средиземноморском регионе; Бангладеш и Индонезия в регионе Юго-Восточной Азии; и Россия в Европейском регионе. В двух из 11 стран (Мозамбик, Южная Африка), показатель заболеваемости попрежнему растет и в двух других (Афганистан, Демократическая Республика 
Конго) держится на том же уровне. Большинство из 11 стран столкнулись с одной или несколькими серьезными проблемами, включая нехватку ресурсов, конфликты и нестабильность, а также генерализованную эпидемию ВИЧинфекции [13].

Роспотребнадзор России в сообщении «0 заболеваемости туберкулезом в Российской Федерации» отмечает, что в 2012 году в Российской Федерации зарегистрировано 96740 случаев туберкулеза, показатель заболеваемости в среднем по стране составил 67,7 на 100 тыс. населения, что несколько меньше, чем в предыдущие годы (2011г. - 72,7, 2010 г. - 76,5 на 100 тыс. населения). Наиболее высокая заболеваемость туберкулезом регистрируется на территории Дальневосточного (122,1 на 100 тыс. населения), Сибирского $(109,7)$ и Уральского $(86,4)$ федеральных округов. Превышение среднего по стране показателя заболеваемости туберкулезом (от 80 до 206 случаев на 100 тыс. населения) зарегистрировано во всех субъектах Дальневосточного и Сибирского федеральных округов, за исключением Томской области, а также в Волгоградской, Астраханской, Курганской, Свердловской, Тюменской, Самарской, Оренбургской областях, Пермском крае, Республике Калмыкия. Снижения заболеваемости туберкулезом детей и подростков в последние годы не происходит. Так, показатель заболеваемости детей в возрасте до 14 лет в 2012 году в среднем по стране составил 16,7 случаев на 100 тыс. детей возрастной группы против 15,3 в 2010 и 16,4 в 2011 годах, при этом по сравнению с 2009 годом отмечается рост этого показателя на 13,7\%. Среди детей до 14 лет наиболее высокий показатель заболеваемости туберкулезом продолжает регистрироваться в возрастной группе 3-6 лет - 20,3 на 100 тыс. детей возрастной группы. По-прежнему, регистрируется на высоком уровне показатель заболеваемости подростков. В 2012 году он составил 31,3 на 100 тыс. возрастной группы. Всего в отчетном году туберкулезом заболело 1374 подростка (2011г. - 1351). Сельские жители составили в 2012 году 28,6\% от всех впервые заболевших больных туберкулезом .В структуре впервые выявленных больных туберкулезом доля лиц, находящихся в учреждениях ФСИН, составила 10,4\%, лиц БОМЖ - 2,2\%, иностранных граждан - 2,8\%. Таким образом, в учреждениях пенитенциарной системы сохраняется значительный резервуар туберкулезной инфекции. Показатель заболеваемости бациллярными формами туберкулеза населения Российской Федерации году составил 27,9 на 100 тыс. населения, что практически на уровне прошлого года. Заболеваемость бациллярными формами сельских жителей - 32,1. При этом в ряде территорий этот показатель существенно превышает таковой по совокупному населению (Курская, Липецкая, Тверская, Кировская, Пензенская, Самарская, Томская области, республики Ингушетия, Марий Эл, Хакасия, Ставропольский, Красноярский, Камчатский и Хабаровский края, Ямало-Ненецкий и Чукотский автономные округа), что предполагает более низкую эффективность мероприятий по раннему выявлению туберкулеза среди сельских жителей по сравнению с городским населением (рис.9,10) [25]. 


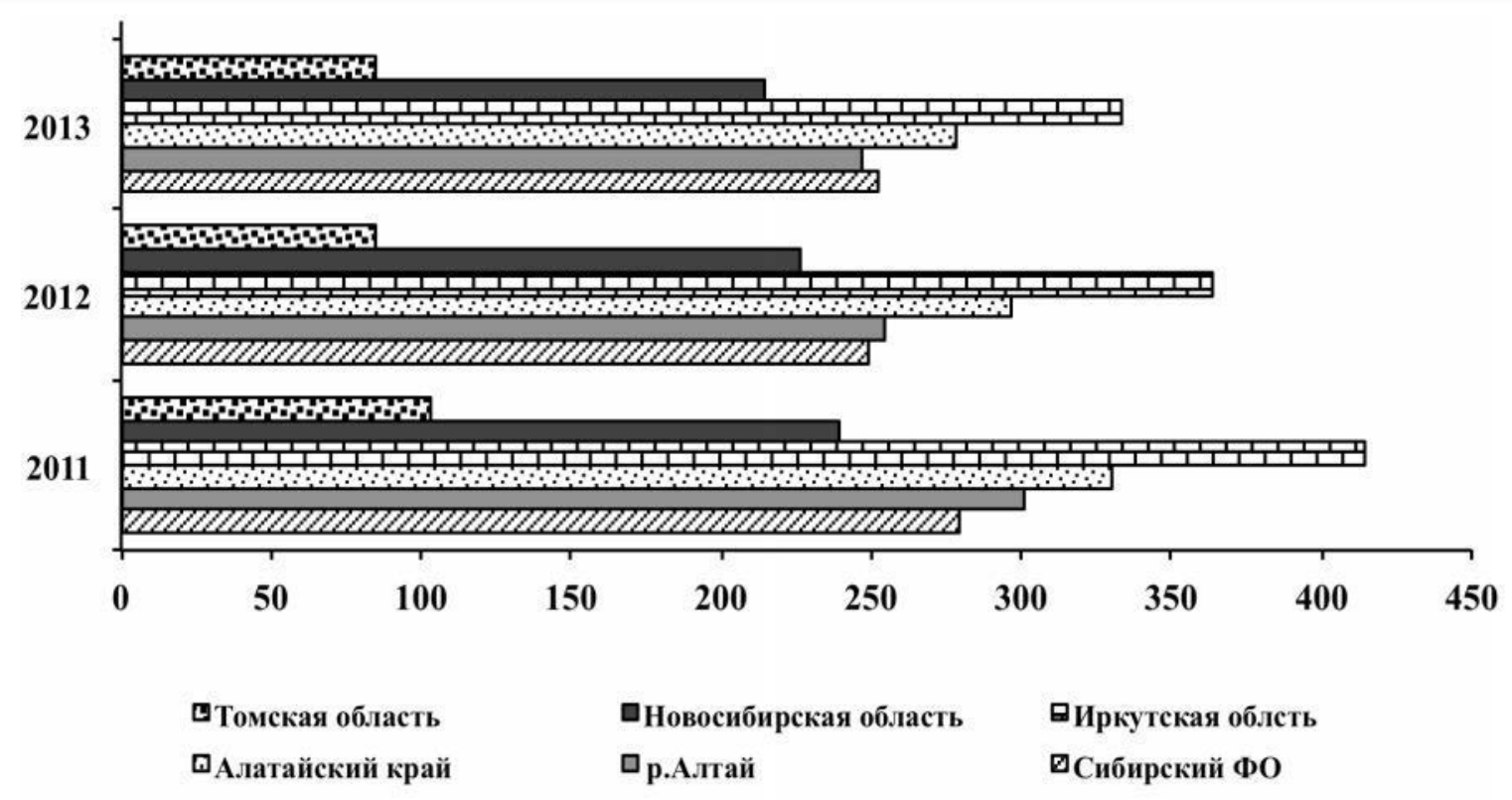

Рис.9. Контингент больных туберкулезом органов дыхания (на 100 тыс. населения) в Сибирском ФО РФ [22, 25, 27]

Актуальной проблемой для Томской области является распространение социально значимых заболеваний: туберкулеза, психических расстройств, ВИЧ-инфекции, дерматовенерологических заболеваний, алкоголизма и наркомании. Необходимо выделить следующие аспекты:

- напряженная эпидемиологическая ситуация по туберкулезу в Томской области. Территориальный показатель заболеваемости не превышает 100,0 на 100 тыс. населения, т.е. не достигает эпидемического уровня (по критериям B03), и в 2011 году составил 75,5 на 100 тыс. населения (отмечается снижение уровня заболеваемости туберкулезом среди категорий всех возрастов). Повышение качества системы своевременного выявления больных туберкулезом в общей лечебной сети путем улучшения системы диагностики туберкулеза, в том числе с использованием ускоренных методов определения лекарственной чувствительности, внедрение подпрограммы по раннему выявлению позволило уделять больше внимания выявлению туберкулеза, в том числе в группах повышенного риска. Показатель смертности от туберкулеза составил по итогам 2011 года 5,6 на 100 тыс. населения - снижение туберкулеза, в том числе в группах повышенного риска. Анализ показателя смертности от туберкулеза составил по итогам 2011 года 5,6 па 100 тыс. населения - отмечено снижение показателя.

По результатам 2011 года рост заболеваемости психическими расстройствами составил в Томской области 9,9\% (2011 год - 602,7). Средний показатель по РФ за 2011 год 622,1 на 100 тыс. населения. Половина страдающих психическими заболеваниями проживает в районах области.

Отмечается высокая распространенность наркологических расстройств среди населения Томской области. Под наблюдением наркологической службы в 2011 году находилось 24307 человек - 2318,2 случая на 100 тыс. населения, из них впервые в 2011 году - 3117 человек (т.е. 297,3 на 100 тыс. населения, наблюдается тенденция снижение показателя). - уровень дерматовенерологи- 
ческих заболеваний практически не изменился (2011 год -56,0 на 1000 населения). Уровень заболеваемости сифилисом в 2011 году снизился на 12,8\% (2011 год - 56,4 на100 тыс. населения), в том числе у детей 0-14 лет в 2011 году заболеваний не зарегистрировано, у подростков 15-17 лет - 41,0), у взрослых $68,0)[18]$.

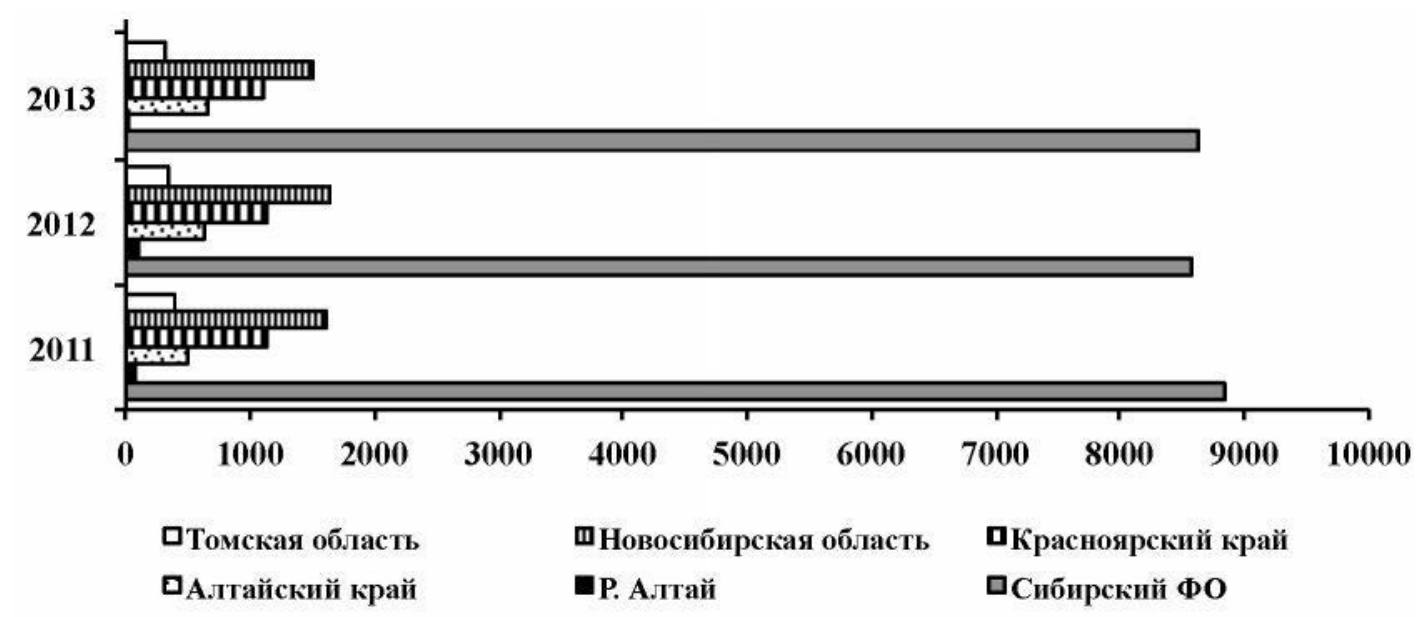

Рис.10. Контингент больных туберкулезом с МлУ МТБ (абс. значения) в Сибирском ФО РФ [22]

Особое внимание необходимо обратить на социально-средовые компоненты репродуктивного потенциала молодёжи - установки и мнения, поведение и мотивации, медицинская активность, уровень информационной подготовки, т.е. те факторы, которые могут существенно повлиять на исход репродуктивных установок [12]. Методом анкетирования нами было установлено, что среди молодых томичей достаточно распространены установки на раннее начало половой жизни (до 16 лет), совместную жизнь без регистрации брака, добрачные и внебрачные сексуальные связи, частую смену партнёров, случайный секс. Поскольку большинство беременностей не планировалось, то основная часть девушек принимала решение об аборте. Причины принятия решения о прерывании беременности у большинства студенток комплексные: наиболее часто в анкетах было указано необходимость продолжения обучения и профессионального роста, отсутствие постоянного партнера, отсутствие денежных средств на воспитание ребенка, психологическая неготовность к материнству.

В условиях долгосрочного экономического и демографического кризиса программы охраны репродуктивного здоровья мужчин и женщин выходят за пределы здравоохранения и напрямую влияют на состояние национальной безопасности. Этот тезис приобретает особое и тревожное звучание в отношении мужской популяции, так как в РФ более трети молодых, соматически здоровых мужчин характеризуется отчетливым снижением уровня сексуальной функции. Кроме того, для двух третей мужчин половозрелого возраста характерно наличие сразу нескольких факторов риска по отношению к половой сфере, следовательно, данные лица формируют обширную группу риска в плане эскалации сексуальной патологии, снижения уровня фертильности у молодых мужчин [1]. В настоящее время необходимо в значительной мере уси- 
лить комплексную деятельность в проведении предгравидарной профилактики репродуктивных потерь, алгоритм которой должен быть индивидуализирован с учетом особенностей состояния репродуктивного потенциала $[12,16$, $21,28,29]$.

Данные статистики демонстрируют негативные явления в институте семьи как в России в целом, так и в Томской области: число разводов неуклонно растёт, а число заключённых браков снижается (табл. 1, 2).

Табл. 1. Оперативные данные по естественному движению населения Российской Федерации с учетом Республики Крым и города федерального значения Севастополя

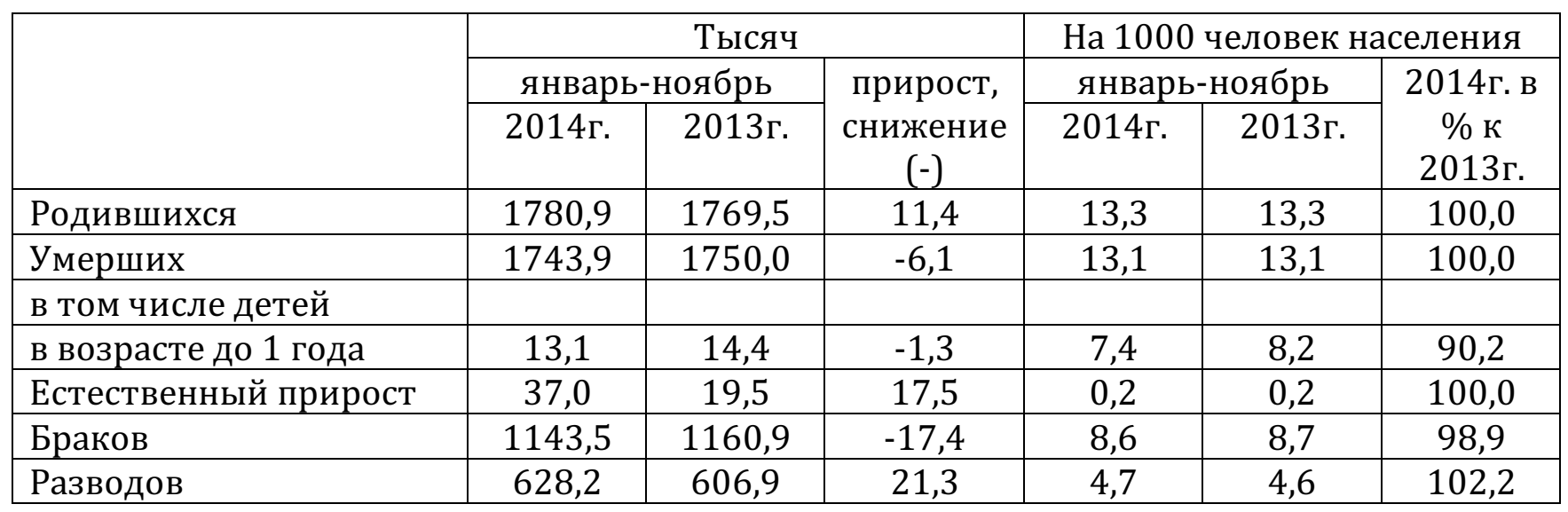

В 2013 году по данным Росстата в России зафиксировано более 1млн. 200 тыс. браков, количество разводов составило 667 971. Самым активным возрастом для заключения браков является период от 25 до 34 лет. В это время совершается практически половина всех браков. К сожалению, очевидно, что та же картина наблюдается и в области разводов. Что касается разводов, то в целом по стране цифра, к сожалению, упорно растет. Соотношение между браками и разводами в целом по стране составляет 70 процентов. Представительницы прекрасной половины предпочитают вступать в брак активнее с 18 лет, в то время как пик брачной активности у мужчин приходится на возраст 25-34 года (рис.11,12, табл.2.) [26,28].
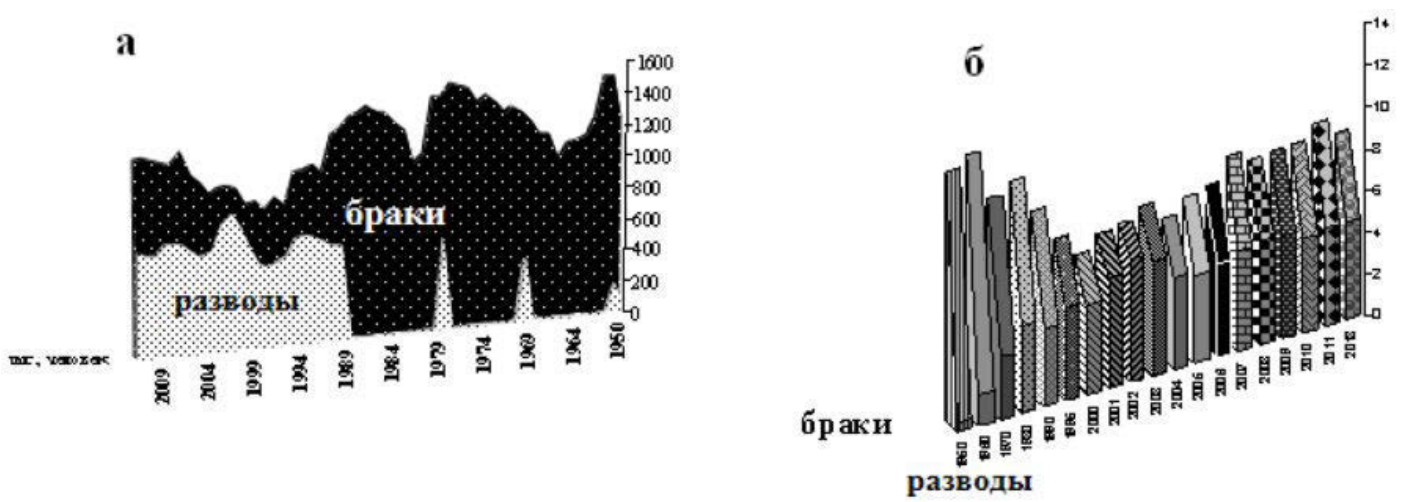

Рис.11. Динамика абсолютных чисел браков и разводов (тыс. человек) в России, 1950 - 2013 гг (а) и количества браков и разводов на 1000 населения в России, 1950 - 2013 г2 (б) [28,27] 


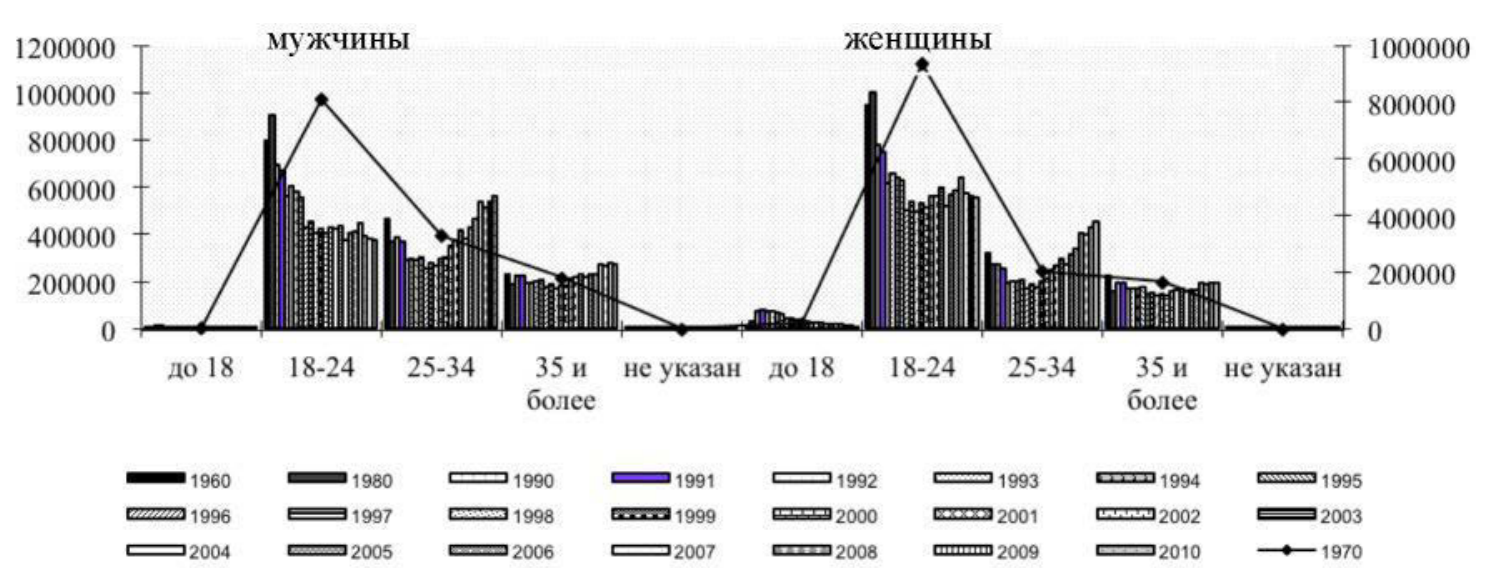

Рис.12. Распределение мужчин и женщин по возрасту вступления в брак в России (1960 - 2010 г2., тыс. человек) [26,27]

Табл.2. Сведения о количестве актов гражданского состояния, зарегистрированных отделами Департамента ЗАГС Томской области за 2013 год

\begin{tabular}{|l|c|c|c|c|}
\hline \multirow{2}{*}{ Наименование отдела } & \multicolumn{5}{|c|}{ Количество зарегистрированных актов гражданского состоя- } \\
\cline { 2 - 5 } & о рождении & о смерти & $\begin{array}{c}\text { о заключе- } \\
\text { нии брака }\end{array}$ & $\begin{array}{c}\text { о расторжении } \\
\text { брака }\end{array}$ \\
\hline $\begin{array}{l}\text { Александровский отдел } \\
\text { ЗАГС }\end{array}$ & 86 & 117 & 80 & 56 \\
\hline Асиновский отдел ЗАГС & 461 & 585 & 375 & 219 \\
\hline Бакчарский отдел ЗАГС & 159 & 206 & 67 & 66 \\
\hline $\begin{array}{l}\text { Верхнекетский отдел } \\
\text { ЗАГС }\end{array}$ & 152 & 185 & 66 & 75 \\
\hline Отдел ЗАГС г. Стрежевого & 542 & 354 & 360 & 296 \\
\hline Тегульдетский отдел ЗАГС & 91 & 102 & 33 & 32 \\
\hline Чаинский отдел ЗАГС & 145 & 165 & 75 & 46 \\
\hline Шегарский отдел ЗАГС & 200 & 445 & 157 & 95 \\
\hline $\begin{array}{l}\text { Отдел ЗАГС г. Томска и } \\
\text { Томского района }\end{array}$ & 9616 & 6668 & 2866 & 3157 \\
\hline Отдел ЗАГС ЗАТО Северск & 1313 & 1368 & 683 & 739 \\
\hline ИТОГО 2013/2014 & $14809 / 14774$ & $12567 / 12654$ & $9125 / 9116$ & $5858 / 5599$ \\
\hline
\end{tabular}

Таким образом, состояние здоровья молодого поколения характеризуется невысоким уровнем соматического (в том числе и репродуктивного) здоровья выпускников общеобразовательных учреждений и молодёжи. Кризисные тенденции в состоянии института семьи, снижение репродуктивного потенциала, ухудшение уровня соматического здоровья, оказывают значительное влияние на социализацию по половому признаку, развитие личности, способность создать семью и, следовательно, - на современную демографическую и экономическую ситуации в стране в целом, что требует комплексного подхода к вопросу сохранения здоровья, формирования здоровьесберегающей культуры у молодого поколения и оптимизации процессов социализации молодёжи. 


\section{Список литературы:}

1. Агасаров Л.Г., Гурџкой Р.А. Перспективы восстановления мужского сексуального здоровья // Материалы ІІ Конгресса Российского общества школьной и университетской медицины и здоровья с международным участием. М.: Научный центр здоровья детей РАМН, 2010. 708 c.

2. Антонов А.И. Демографическая деградация в России // Материалы всероссийской научной конференции. М., 2007. С. 103.

3. Белобородов И.И. Снижение смертности или повышение рождаемости: к вопросу о приоритетах демографической политики // Социальная политика и социология. 2008. №3. С. 158-166.

4. Возрастно-половой состав и состояние в браке населения Томской области // Статистический сборник №2. Ч. 1, 2. Томск, 2004. 50 с.

5. Всероссийская перепись населения 2002 2. URL: http://www.perepis2002.ru

6. Всероссийская перепись населения 2010 2. URL:http://video.yandex.ru/users

7. Жуков В.И. Демографический потенциал России. М.: РГСУ, 2010.

8. Жуков В.И. Россия в глобальном мире. Т. 1. Философия и социология преобразований. М.: Логос, 2006. $440 \mathrm{c}$.

9. Здравоохранение Томской области. URL: http://zdrav.tomsk.ru/

10. Здравоохранение Томской области: проблемы и перспективы // Материалы к парламентским слушаниям. Томск, 2004. 90 с.

11. Елизаров В.В. Демографическая политика в России от размышления к действию. М., 2008. 90 c.

12. Колосова М.В. Роль молодёжи Томской области в формировании демографического и экономического ресурсов региона // Ученые записки РГСУ. 2013. Т. 2. № 2. С. 50-62.

13. Обратный отсчет до 2015. Доклад ВОЗ о глобальной борьбе с туберкулезом Информационный центр по изучению проблем туберкулеза в России. URL: http://tbrussia.info/1905988/

14. О демографической ситуации в Томской области.

URL: http://tomsk.gov.ru/ru/social_ground/standard_life

15. Официальный сайт администрации Томской области. URL: http://www.tomsk.gov.ru

16. Посисеева Л.В., Бойко Е.Л. Репродуктивное здоровье мужчин и пути его улучшения // Курортные ведомости. 2009. № 6. С. 13-17.

17. Постановление Государственной думы Томской области от 27.04.2007 № 80 «0 конщепции демографического развития Томской области до 2010 года».

18. Приказ департамента Томской области от 2013 №11 «Предупреждение распространения социально значимых заболеваний в Томской области».

19. Проблемы охраны репродуктивного здоровья подростков // Красное знамя. 2008. № 7. С. 3.

20. Распоряжение Правительства РФ № 1193-р от 15 августа 2008 г. «О Конщепџии действий на рынке труда на 2008-2010 г2.» // Собрание законодательства РФ. 2008. 25 авг. № 34. Ст. 3964.

21. Репродуктивная активность женщин Томской области в 2007 году // ОГУЗ «Бюро медицинской статистики». 2008. $50 \mathrm{c.}$

22. Гордина А.В, Зайченко Н.М., Кучерявая Д.А. Ресурсы и деятельность противотуберкулезных организаций в $2011-2013$ гг.

23. Жуков В.И. Российская Семья: социальный атлас. М.: РГСУ, 2009. 136 c.

24. Россия в цифрах, основные показатели. URL: http://www.gks.ru/

25. Сайт роспотребнадзора. URL: http://rospotrebnadzor.ru/a туберкулез

26. Сайт Виктора Kресса. URL: http://kress.tomsk.ru/publications/speeches/posts/

27. Сайт Федеральной службы госстатистики России.

URL: http://www.gks.ru/wps/wcm/connect/rosstat/rosstatsite/main/population/demography/

28. Сведения о количестве актов гражданского состояния. URL: http://zags.tomsk.gov.ru/stats/stats

29. Титаренко И.Н., Осадчук Л.В. Оценка мужского репродуктивного здоровья молодежи Кузбасса.

URL: http://www.ecuro.ru/article/otsenka-muzhskogo-reproduktivnogo-zdorovya

30.Тюрина И.О. Гендерные аспекты занятости и управления // Журнал СОЦИС. 2010. № 11. 135 с.

\section{References:}

1. Agasarov L.G., Gurtskaya R.A. Prospects of renewal of masculine sexual health. // Materials of II of Congress of Russian society of school and university medicine and health with international participation. M.: Publisher the Scientific center of health of children of PAMH, 2010. 708 .

2. Antonov A.I. Demographic degradation in Russia // Materials of all-russian scientific conference. M. 2007.

P. 103.

3. Byeloborodov I.I. Decline of death rate or increase of birth-rate: to the question about priorities of demographic politics // Social politics and sociology. 2008. №3. Pp. 158-166. 
4. Age-related-sexual composition and state in marriage of population of the Tomsk area // Statistical collection. №2. Pt. 1, 2. Tomsk, 2004. 50 p.

5. All-Russian census of population 2002. URL: http://www.perepis2002.ru

6. All-Russian census of population of a 2010. URL: http://video.yandex.ru/users

7. Zhukov V.I. Demographic potential of Russia: electronic scientifically-educational edition. М.: РГСУ, 2010.

8. Zhukov V.I. Russia in the global world. Vol. 1. Philosophy and sociology of transformations. M., 2006. 440 p.

9. Health protection of the Tomsk area. URL: http://zdrav.tomsk.ru/

10. Health protection of the Tomsk area: problems and prospects // Materials to the parliamentary listening.

Tomsk, 2004. 90 p.

11. Elizarov V.V. Demographic politics in Russia from a reflection to the action. M., 2008. 90 p.

12. Kolosova M.V. Role of young people of the Tomsk area in forming demographic and economic resources of region the Scientific messages of RGSU. 2013. Vol. 2. № 2. Pp. 50-62.

13. Reverse counting out to 2015. Lecture of BO3 about a global fight against tuberculosis the Informative center on the study of problems of tuberculosis in Russia. URL: http://tbrussia.info/1905988/

14. About a demographic situation in Tomsk area. URL: http://tomsk.gov.ru/ru/social ground/standard life.

15. Official web-site of administration of the Tomsk area. URL: http://www.tomsk.gov.ru

16. Posiseyeva L.V., Boyko E.L. Reproductive health of men and ways of his improvement // the Resort lists. 2009. № 6. Pp. 13-17.

17. Decision of State thought of the Tomsk area from 27.04.2007 № 80 "About conception of demographic development of the Tomsk area to 2010".

18. Order of department to the Tomsk area from. 2013. № 11.

19. Problems of reproductive health of teenagers // care Red banner. 2008. № 75. P. 3.

20. Disposing of Government Russian FEDERATION № of 1193-p from August, 152008 21.Reproductive activity of women of the Tomsk area in 2007. Bureau of medical statistics. 2008. 50 p.

22. Gordina A.V. Resources and activity of antiphthisic organizations in 2011 - 2013. Statistical materials. M.:

РИО ЦНИИОИЗ, 2014. 93 p.

23. Zhukova V.I. Russian Family: social atlas. M.: RGSU, 2009. 136 p.

24. Russia in numbers, basic indicator. URL: http://www.gks.ru/

25. Site of Rosobrnadzor. URL: http://rospotrebnadzor.ru/a tuberculosis

26. Web-site of Victor Cress. URL: http://kress.tomsk.ru/publications/speeches/posts/

27. Web-site of Federal service of state statistics to Russia.

URL: http://www.gks.ru/wps/wcm/connect/rosstat/rosstatsite/main/population/demography/

28. Taking about the amount of acts of the civil state. URL: http://zags.tomsk.gov.ru/stats/stats

29. Titarenko I.N., Osadchuk L.V. Estimation of masculine reproductive health of young people of Kusbass.

URL: http://www.ecuro.ru/article/otsenka-muzhskogo-reproduktivnogo-zdorovya

30. Tyurina I.O. Gender aspects of employment and management // SOCIS. 2010. № 11. 135 p.

(C) 2014, Колосова М.В.

Вклад молодёжи Томской области в формирование стратегического ресурса регионов Сибири
(C) 2014, Kolosova M.V.

Contribution of young people of the Tomsk area to forming of strategic resource of regions of Siberia 
DOI: 10.17117/no.2014.01.154

Поступило в редакцию: 04.11.2014

asu@asu.edu.ru

\title{
Байбатырова Н.М. Концептуальные особенности публицистики и литературной критики М.Н. Эпштейна
}

\author{
Baybatyrova N.M. \\ Conceptual features of journalism and literary \\ criticism M.N. Epstein
}

Статья посвящена литературно-

публицистическому творчеству автора «третьей волны» русской эмиграции М.Н. Эпштейна.

Содержательная концепция его текстов имеет явные признаки междисциплинарности. М.Н.

Эпштейн не ограничивает себя рамками только писательства, философии или филологии. Каждая из рассматриваемых книг представляет собой синтез историко-литературного исследования и публицистики. В рамках своих исследований представитель русского зарубежья вводит ряд новых авторских понятий, помогающих ориентироваться в современной культуре: «лирический музей», «экология мышления», «метабола», «кенотип». Он обрисовывает перспективы синтеза, слияния разных искусств и типов сознания

Ключевые слова: эмиграция, третья волна, публицистика, литературная критика, авторские неологизмы

\section{Байбатырова Наиля Мунировна}

Кандидат филологических наук, доцент Астраханский государственный университет 2. Астрахань, ул. Татищева, 20 А
The article is devoted to the literary and publicistic work of the author of the third wave of Russian emigration M. Epstein. A meaningful concept in his texts has obvious signs of interdisciplinarity. $M$. Epstein does not limit himself only literature, philosophy or Philology. Each of these books represents a synthesis of historical and literary studies and journalism. As part of their studies the representative of the Russian Diaspora introduces a number of new copyright concepts to help navigate in contemporary culture: "the lyrical museum", "ecology of thought", "metabole", "genotip". He outlines the prospects of synthesis, fusion of different art and types of consciousness

Key words: emigration, the third wave, publicism, literary criticism, author's neologisms

\author{
Baybatyrova Nailya Munirovna \\ Candidate of Philology Sciences, docent \\ Astrakhan State University \\ Astrakhan, Tatischev St., 20 A
}

Литературная критика всегда была широко представлена в отечественной публицистике, как в дореволюционный, так и в советский, а затем постсоветский период. Критика русского зарубежья каждой из «волн» эмиграции, безусловно, приобретала собственные уникальные черты, формировавшиеся в конкретных социально-исторических условиях. Литературно-критическое творчество, а также литературоведческие и эссеистические работы эмигранта «третьей волны» М.Н. Эпштейна представлены публикациями в американских 
и российских изданиях преимущественного перестроечного и постсоветского периодов, а также монографиями.

Михаил Наумович Эпштейн - заслуженный профессор теории культуры и русской литературы университета Эмори (Атланта), член российского Пенклуба и Академии российской современной словесности. Практически сразу после переезда на Запад он вошел в редколлегии нескольких американских научных журналов. Задолго до эмиграции М.Н. Эпштейн начал осваивать эссеистическую форму творчества. Концепция публицистики автора имеет явные признаки космополитизма. Передставитель «третьей волны» эмиграции не ограничивает себя рамками только писательства, философии или филологии. Сфера его интересов поистине универсальна: от метафизики русской классики и теории постмодернизма до изобретения новых слов и гуманитарных дисциплин. Хотя ученый живет и работает в США, он много печатается в России. В интервью М.Н. Эпштейн рассказывает о своих электронных словарях и сетевых проектах, включая «Виртуальную библиотеку», где представлены электронные версии многих его книг и статей.

Широко известна книга М.Н. Эпштейна «Постмодерн в России: литература и теория». Монография писалась с 1982 по 1998 гг. одновременно со становлением самого российского постмодернизма. Она представляет собой разностороннее литературно-теоретическое исследование российского постмодерна, его истоков и основных этапов развития в XX веке, а также его культурноисторических отличий от западного постмодернизма. Первоначально некоторые главы, составляющие книгу «Постмодерн в России», публиковались в виде отдельных статей в журналах «Знамя», «Звезда», «Октябрь», «Золотой век», «Стрелец», «Новое литературное обозрение», «Слово» (Нью-Йорк), а также в американских англоязычных изданиях. Позже ряд глав был переработан для издания книги. М.Н. Эпштейном выдвигается оригинальная концепция конца Нового времени и соотношения постмодернизма с коммунизмом, модернизмом, экзистенциализмом. «Мне представляется, что сходство постмодернизма и коммунизма как программных методов воздействия на общественное сознание далеко не случайно, они представляют собой в России две фазы становления одного идейно-эстетического проекта. Если коммунизм провозглашал грядущее торжество идей, преображающих реальность, то постмодернизм обнаруживает уже отсутствие какой-либо другой реальности, кроме реальности самих идей (знаков, образов, наименований), - заявляет автор. В главах монографии М.Н. Эпштейн рассматривает основные литературные и теоретические программы постмодерна в творчестве А. Синявского, И. Кабакова, Вен. Ерофеева, Т. Кибирова. Анализу подвергнуты и отдельные литературные направления: метареализм, концептуализм, соц-арт, арьергард, - что позволяет более глубоко исследовать феномен российского литературного постмодернизма. Для этой книги М. Эпштейна характерен энциклопедический охват при сохранении излюбленной автором эссеистической формы изложения. Художественное произведение для писателя - прежде всего текст, эстетический феномен, функционирующий по присущим ему законам. 
М.Н. Эпштейн рассматривает предпосылки постмодернизма, диалектику перехода от модернизма к постмодернизму, своеобразие российско-советского постмодерна, его взаимоотношения с соцреализмом и соц-артом. Автор русского зарубежья анализирует литературно-художественные движения метареализма, концептуализма, арьергарда, наконец, пишет о постмодернизме как о первой стадии постмодерности. «Пожалуй, со времен социального реализма не возникало «изма», который до такой степени привлек бы внимание и нормативную установку художественной публики. Появление нового понятия вызвало к жизни множество специально скроенных под него произведений и позволило задним числом осознать ранее созданные произведения как возвещающие его возникновение», - с долей иронии пишет М.Н. Эпштейн.

Жанр эссе, собранных в научную монографию позволяет авторуэмигранту, с одной стороны, оценить многие литературные явления современности с позиции космополитического мышления, с другой - не стесняет свободу изложения. Так, например, М.Н. Эпштейн смело высказывается, сравнивая историко-географические факторы возникновения и существования постмодернизма как литературного направления: «Хотя постмодернистские учения пришли в Россию с Запада, главным образом из Франции и США, сама готовность российских умов мгновенно размножить и применить эти учения к родной культуре и сделать их знаменем духовного обновления, говорит о некоторой соприродности постмодернизма российской почве».

Другая литературно-критическая книга - «Парадоксы новизны: О литературном развитии XIX-XX веков» - представляет собой синтез историколитературного исследования и публицистики. Статьи этой книги М.Н. Эпштейна имеют свободную теоретическую композицию. Каждая статья тематически самостоятельна, но все главы связаны проблемно. В каждой из глав исследуется литературная или общекультурная ситуация. Автор объясняет: «Литературный процесс рассматривается при этом не в его исторической постепенности и протяженности, а в его, так сказать, диалектических сгущениях, моментах наибольшего напряжения противоречий, которые либо выводят культуру на новый уровень развития, либо, замыкаясь на себе, приводят в состояние кризиса».

В «Парадоксах новизны» нет теоретически развернутых категорий и строгих дефиниций, нет даже исторически последовательного изложения литературных событий. М.Н. Эпштейн на обширном материале: от Гете и Пушкина до Мандельштама и Набокова - раскрывает творческую роль парадоксов в развитии культуры. В книге прослеживаются духовные процессы, отмеченные знаком парадоксальности: культ плоти в «сексуальной революции» (Д.-Г. Лоуренс, Г. Миллер); экспансия игры в сферы «серьезной деятельности»; воздействие религиозно-онтологического сознания на искусство авангарда; противопоставление концептуализма и метареализма в поэзии конца XX в. (Д. Пригов, О. Седакова, И. Жданов, А. Еременко, А. Парщиков).

М.Н. Эпштейн в рамках своего исследования вводит ряд новых авторских понятий, помогающих ориентироваться в современной культуре: «лирический музей», «экология мышления», «метабола», «кенотип». Автор обрисовывает 
перспективы синтеза, слияния разных искусств и типов сознания. Основополагающим термином для своего труда автор считает понятие «парадокс», вынесенный в заглавие: «... это не просто проблема, а высшая степень ее заостренности, доходящая порой до гротескной несообразности или трагической неразрешимости, но всякий раз способствующая предельной концентрации творческих усилий», - так М.Н. Эпштейн определяет парадоксы как феномен. Парадоксы, строящиеся на противоречиях, по глубокому убеждению писателя, необходимы. Он рассматривает философско-эстетические антитезы: «реальность» - «идеал», «природа» - «искусство», «массовое» - «индивидуальное», «гармония» - «ирония», «правдивость» - «условность», «интуиция» - «рефлексия», «миф» - «документ», «вещь» - «слово», - и обосновывает их важность и необходимость в современной культуре.

Рассмотрим некоторые другие авторские понятия-неологизмы, вводимые автором для анализа литературных и культурных парадоксов. Во втором разделе «Выбор традиции» М.Н. Эпштейн помещает статью под названием «От метафоры к метаболе». Здесь он вводит новый для читателя литературный термин. «Метабола - это образ, не делимый надвое, на прямое и переносное значение, на описанный предмет и привлеченное подобие, это образ двоящейся и вместе с тем единой реальности», - пишет автор. Метабола дает возможность читателю осязать текст, особенно поэтический. Метабола не противопоставлена у писателя традиционной метафоре, причем часто в одном стихотворении происходит движение от метафоры к метаболе. Метареалисты видят в метаболе путь искания целостности, возводят читателя на новый уровень поэтического сознания.

В статье «Неоязычество» М.Н. Эпштейн на примере романов Д. Г. Лоуренса вводит новое одноименное понятие. Неоязычество - это одухотворение природы в себе и вокруг себя: «Трехтысячелетний цикл развития человечества должен замкнуться возвратом его в лоно природы, слиянием и отождествлением с ней - как будто весь исторический труд по освобождению из уз был ошибочен и напрасен». М.Н. Эпштейн разграничивает два вида неоязычества: волюнтаристского и гедонистического толка. Внутри же самого язычества писатель выделяет несколько ступеней, которым соответствуют разные направления неоязычества: от Ницше до Фрейда. Умопостигаемый предел неоязычества - это живое, хотя и бездуховное, тело. При этом человек находится на вершине эволюции, но на дне социальной истории. Неоязычество, представителем которого М.Н. Эпштейн называет Фрейда, стремится вернуть человека к первобытному состоянию, объясняя все инстинктами.

Другой авторский культурный неологизм писателя-эмигранта - «лирический музей», в нем каждая вещь наряду с материальной, исторической, художественной ценностью может обладать личностной или лирической ценностью. Об этом пишет автор в главе «Вещь и слово. 0 лирическом музее». «Назначение этого музея - раскрыть бесконечно разнообразное и глубокое значение вещей в человеческой жизни, их богатый образный и понятийный смысл, вовсе не сводимый к утилитарному применению», - рассуждает М.Н. Эпштейн. Он анализирует, как XX в. создал два грандиозных символа отчужде- 
ния вещи от человека: склад и свалку. «С одной стороны, вещи, не дошедшие до человека, не нуждающиеся в нем, надменно поблескивающие своими этикетками. С другой стороны, вещи брошенные, потерявшие внимание и заботу, запыленные, загаженные, преждевременно гниющие и ржавеющие. Накопительство и попустительство - явления противоположные, но взаимосвязанные, у них одна причина - неосвоенность вещей, на которые у человека «не хватает» души», - философски резюмирует М.Н. Эпштейн. Писатель анализирует взаимопересечение материальной вещи и культуры. Он говорит, что в «лирическом музее» могут и должны быть выставлены произведения повседневного духовного творчества, писатель обосновывает понятие «домашняя культура», где вещь выводится за пределы частного быта в большой мир.

Одно из наиболее популярных и адаптированных понятий, вводимых автором-эмигрантом в книге «Парадоксы новизны», - «экология мышления». Оно подразумевает, что власть идей в современном обществе сходит на нет. «Идеи, - пишет М.Н. Эпштейн, - должны вернуться в среду естественного мышления, раствориться в ее органике». Он подчеркивает, что мышление - это самоценная потребность и чистая радость человеческого ума. Писательэмигрант призывает людей быть первопроходцами - экологами ноосферы, хранителями ее чистоты: «Экология мышления - это новая дисциплина разума, возникающая в зрелый период его развития, когда разум уже не может довольствоваться прикладной функцией жизнеустройства, но обнаруживает себя как самостоятельную и целостную реальность. Цель этой реальности - не в чем ином, как в ней самой».

Концептуальные особенности литературной критики М.Н. Эпштейна проявляются в синтезе с научно-популярными жанрами. Мировоззрение русского человека исследуется автором во взаимодействии с природой. Этому посвящена научно-популярная книга автора-эмигранта «Природа, мир, тайник вселенной...: Система пейзажных образов в русской поэзии». М.Н. Эпштейн выделил и проанализировал четыре этапа в развитии лирической натурфилософии. Он подчеркивает, что «цивилизация не превзошла природу, а еще только находится на подступах к ней, только начинает осознавать нерасторжимость своего союза с ней - это мироощущение в основе современной лирической натурфилософии».

Философская публицистика М.Н. Эпштейна представлена книгой «Великая Совь»и тремя эссеистическими циклами. В произведении «Великая Совь», законченном в 1988 г., автор разработал и обосновал мифологическую систему Советского Союза. Книга близка жанру философского фэнтези на темы советской жизни. М.Н. Эпштейна называют претендентом на авторство жаргонного слова «совок». На родине произведение не могло быть опубликовано. Только во время первого выезда М.Н. Эпштейна на Запад в начале 1989 г., автору удалось выступить с циклом передач на радиостанции Би-би-си из Лондона, где он читал радиослушателям «Великую Совь». В числе пяти глав была прочитана глава «Социальные группы» с характеристикой «совков». Из прочитанных по радио глав книги обидное прозвище, вероятно, проникло в СССР. Хотя и другие авторы русского зарубежья второй половины XX века - А. Генис и П. Вайль - 
отстаивали свою причастность к неологизму «совок». Они утверждали, что придумали это слово для обозначения советских туристов, выезжающих в социалистические страны».

М.Н. Эпштейн одним из первых синтезировал научное и литературное творчество. Он - автор 15 книг и около 300 статей и эссе, переведенных на десять языков мира. Критические статьи, труды по философии и лингвистике, архив эссеистики советского периода творчества М. Эпштейна, мультидисциплинарные и разножанровые работы автора составляют концептуальное ядро его публицистики.

\section{Список литературы:}

1. Богданова О.В. Постмодернизм в контексте современной русской литературы (60-90-е годы ХХ века - начало ХХІ века). СПб.: Филол. фак. СПбГУ, 2004. 716 с.

2. Критика русского зарубежья. Ч.2. М.: Олимп, 2002.

3. Курицын В. Русский литературный постмодернизм. М.: ОГИ, 2000. 288 c.

4. Цымбалистенко Н.В. Постмодернизм в литературе русского зарубежья «третьей волны» эмиграции // Эйхенбаумовские чтения. Воронеж, 1996. С. 63-65.

5. Чернов В., Кузнещов И.В., Зеленина Е.В. Убийство русской литературы. Публицистика русского зарубежья. М., 1999.

6. Эпштейн М. Бог деталей. Народная душа и частная жизнь в России на исходе империи.

Эссеистика 1977-1988. М.: Издание Р. Элинина, 1998.

7. Эпштейн М. Великая Совь. Философско-мифологический очерк. Нью-Йорк: Слово, 1994. 177 с.

8. Эпштейн М. Вера и образ: религиозное бессознательное в русской культуре ХХ веке. Тепаfly, 1994.

C. 83.

9. Эпштейн М. Все эссе. Т. 1. В России. Екатеринбург: У-Фактория, 2005. 544 c.

10. Эпштейн М. Все эссе. Т. 2. Из Америки. Екатеринбург: У-Фактория, 2005. 704 c.

11. Эпштейн М. Законы свободного жанра. Эссеистика и эссеизм в культуре Нового времени //

Вопросы литературы. 1987. №7. С. 120-152.

12. Эпштейн М. Истоки и смысл русского постмодернизма // Звезда. 1996. №8. С. 166-188.

13. Эпштейн М. Ленин - Сталин // Родник. Рига, 1989. №6. С. 32-39

14. Эпштейн М. На границах культур: российское - американское - советское. Нью-Йорк: Слово, 1995. $344 \mathrm{c}$.

15. Эпштейн М. Новое сектантство: типы религиозно-философских умонастроений в России. 1970-1980-е годы. Холиоке (Массачусетс): Нью-Ингленд Паблишинг Ко., 1993. 179 с.

16. Эпштейн М. От модернизма к постмодернизму: Диалектика «гипер» в культуре ХХ века // Новое литературное обозрение. 1995. № 16.

17. Эпштейн М. Парадоксы новизны: О литературном развитии ХIX - ХХ веков. М.: Советский писатель, 1988. $416 \mathrm{c}$.

18. Эпштейн М. После будущего. О новом сознании в литературе // Знамя. 1991. № 1. С. 217-230.

19. Эпштейн М. Постмодерн в России: литература и теория. М.: ЛИА Р. Элинина, 2000. 367 c.

20. Эпштейн М.Н. «Природа, мир, тайник вселенной...: Система пейзажных образов в русской поэзии».

М.: Высшая школа, 1990. 303 c.

21. Эпштейн М. Эссе об эссе // Опыты. Журнал эссеистики, публикаций, хроники. Петербург-Париж, 1994. C. 23-26.

\section{References:}

1. Bogdanova O. Century Postmodernism in the context of modern Russian literature (60 to 90-ies of XX century

- the beginning of XXI century). SPb.: The topic of degree work. the FAK. St. Petersburg state University, 2004.

$716 p$.

2. Criticism of the Russian Diaspora: 2 Hours. M.: Olympus, 2002.

3. Kuritsyn V. Russian literary postmodernism. M.: OIG, 2000. 288 p.

4. Cymbalista N.V. Postmodernism in literature of Russian emigration "third wave" of emigration //

Ejhenbaum's reading: Abstracts of international scientific conference. Voronezh, 1996. Pp. 63-65.

5. Chernov V., Kuznetsov I.V., Zelenin E.C. Century The murder of Russian literature // Journalism Russian

Diaspora: Sat. articles. M., 1999. 
6. Epstein M. the God of details. Folk soul and private life in Russia at the end of the Empire. Essays between 1977 and 1988. M.: Publishing R. Alinine, 1998.

7. Epstein M. The Great Whole. Philosophical and mythological essay. New York: Word, 1994. 177 p.

8. Epstein M. Faith: the religious unconscious in Russian culture of the twentieth century. Tenafly, 1994. 83 p.

9. Epstein M. All essays. Vol. 1. So In Russia. Ekaterinburg: Supplement, 2005. 544 p.

10. Epstein M. All essays. Vol. 2. From America. Ekaterinburg: Supplement, 2005. 704 p.

11. Epstein M. the Laws of the free genre. Essays and essenism in the culture of New time // the Questions of literature. 1987. № 7. Pp. 120-152.

12. Epstein M. the Origins and meaning of Russian postmodernism // Star. 1996. № 8. Pp. 166-188.

13. Epstein M. Lenin - Stalin // Spring. Riga, 1989. № 6. Pp. 32-39.

14. Epstein M. At the boundaries of cultures: Russian - American - Soviet. New York: Word, 1995. 344 p.

15. Epstein M. The new sectarianism: the types of religious and philosophical mindset in Russia. 1970-1980-ies.

Holyoke (Massachusetts): New England Publishing Co., 1993. 179 p.

16. Epstein M. From modernism to postmodernism: the Dialectics of "Hyper" in the culture of the XX century // New literature almanac. 1995. № 16.

17. Epstein M. the Paradox of novelty: the literary development of the XIX - XX centuries. M.: Soviet writer, 1988.

$416 p$.

18. Epstein M. After the future. About the new consciousness in literature // Banner. 1991. № 1. Pp. 217-230.

19. Epstein M. Postmodern in Russia: literature and theory. M: LEAH R. Alinine, 2000. 367 p.

20. Epstein M. "Nature, the world, the hiding of the universe...: System landscape images in Russian poetry".

M.: Higher school, 1990. 303 p.

21. Epstein M Essay about essay // Experiments. Journal essays, publications, news. Petersburg-Paris, 1994.

Pp. 23-26.

(C) 2014, Байбатырова Н.M.

Концептуальные особенности публицистики и литературной критики М.Н. Эпштейна
(C) 2014, Baybatyrova N.M.

Conceptual features of journalism and literary

criticism M.N. Epstein 